\title{
Anesthetic interactions with lysophosphatidate signaling
}

Citation for published version (APA):

Durieux, M. E. (1999). Anesthetic interactions with lysophosphatidate signaling. [Doctoral Thesis, Maastricht University]. Universiteit Maastricht. https://doi.org/10.26481/dis.19990604md

Document status and date:

Published: 01/01/1999

DOI:

10.26481/dis.19990604md

Document Version:

Publisher's PDF, also known as Version of record

\section{Please check the document version of this publication:}

- A submitted manuscript is the version of the article upon submission and before peer-review. There can be important differences between the submitted version and the official published version of record.

People interested in the research are advised to contact the author for the final version of the publication, or visit the DOI to the publisher's website.

- The final author version and the galley proof are versions of the publication after peer review.

- The final published version features the final layout of the paper including the volume, issue and page numbers.

Link to publication

\footnotetext{
General rights rights.

- You may freely distribute the URL identifying the publication in the public portal. please follow below link for the End User Agreement:

www.umlib.nl/taverne-license

Take down policy

If you believe that this document breaches copyright please contact us at:

repository@maastrichtuniversity.nl

providing details and we will investigate your claim.
}

Copyright and moral rights for the publications made accessible in the public portal are retained by the authors and/or other copyright owners and it is a condition of accessing publications that users recognise and abide by the legal requirements associated with these

- Users may download and print one copy of any publication from the public portal for the purpose of private study or research.

- You may not further distribute the material or use it for any profit-making activity or commercial gain

If the publication is distributed under the terms of Article $25 \mathrm{fa}$ of the Dutch Copyright Act, indicated by the "Taverne" license above, 
Anesthetic interactions with lysophosphatidate signaling 
(C) Marcel Durieux, Charlottesville 1999

Printed at the University of Virginia

Cover: author's impression of a Xenopus laevis oocyte under two-electrode voltage clamp. The cell is impaled by two electrodes. A micropipette releases lysophosphatidate onto the cell. The inset shows a lysophosphatidate molecule interacting with its receptor in the cell membrane. 


\section{Anesthetic interactions with}

lysophosphatidate signaling

\section{PROEFSCHRIFT}

ter verkrijging van de graad van doctor aan de Universiteit Maastricht, op gezag van de Rector Magnificus, Prof. dr. A.C. Nieuwenhuijzen Kruseman, volgens het besluit van het College van Dekanen, in het openbaar te verdedigen op 4 juni 1999 om 14.00 uur

door

Marcel E. Durieux

geboren 11 november 1959 te Krommenie 


\section{Promotor:}

Prof. dr. S. de Lange

\section{Beoordelingscommissie:}

Prof. dr. H. Struijker Boudier (voorzitter), Universiteit Maastricht

Prof. dr. K.R. Lynch (University of Virginia, Charlottesville, VA, USA)

Prof. dr. J.T.A. Knape, academisch ziekenhuis Utrecht

Prof. dr. H.W.M. Steinbusch, Universiteit Maastricht

Dr. P.M.H.J. Roekaerts, academisch ziekenhuis Maastricht 
to Marijke,

to my parents and children,

and to the people in my laboratory, without whom this never could have happened 


\section{Contents}

Table of Abbreviations 8

Chapter 1 Introduction and Aims 9

Chapter 2 Anesthetic Interactions with Membrane Signaling Molecules 13

Chapter 3 Lysophosphatidate Signaling 31

Chapter 4 Receptor Expression in Oocytes 45

Chapter 5 Lysophosphatidic Acid Induces a Pertussis Toxin-Sensitive $\mathrm{Ca}^{2+}$ Activated $\mathrm{Cl}^{-}$Current in Xenopus laevis Oocytes 55

Chapter 6 Responses to Sphingosine-1-Phosphate in X. Laevis Oocytes: Similarities with Lysophosphatidic Acid Signaling 67

Chapter 7 OoClamp: an IBM-Compatible Software System for Electrophysiologic Receptor Studies in Xenopus Oocytes 79

Chapter $8 \quad$ Trypsin Induces $\mathrm{Ca}^{2+}$-Activated $\mathrm{Cl}^{-}$Currents in X. Laevis Oocytes 87

Chapter 9 Interactions Between Propofol and Lipid Mediator Receptors: Inhibition of Lysophosphatidate Signaling 97

Chapter 10 Differential Inhibition of Lysophosphatidate Signaling by Volatile Anesthetics 109

Chapter 11 Inhibition of Lysophosphatidate Signaling by Lidocaine and Bupivacaine 129

Chapter 12 Summary and Conclusions/Samenvatting en Conclusies 145

Acknowledgments 154

List of publications 155

Curriculum vitae 161 


\begin{tabular}{|c|c|}
\hline $\mathrm{ADP}$ & Adenosine bisphosphate \\
\hline AMPA & $\alpha$-amino-3-hydroxy-5-methyl-4-isoxazole propionate \\
\hline ATP & Adenosine trisphosphate \\
\hline BK channel & $\mathrm{Ca}^{2+}$-activated $\mathrm{K}^{+}$channel \\
\hline $\mathrm{BSA}$ & Bovine serum albumin \\
\hline C terminus & Carboxy terminus \\
\hline cAMP & Cyclic adenosine monophosphate \\
\hline cDNA & Complementary DNA \\
\hline cLPA & Cyclic LPA \\
\hline CMV & Cytomegalovinus \\
\hline CNS & Central nervous system \\
\hline cRNA & Complementary RNA \\
\hline $\mathrm{DAG}$ & Diacylglycerol \\
\hline DNA & Deoxyribonucleic acid \\
\hline $\mathrm{EC}_{50}$ & Half-maximal effect concentration \\
\hline EGTA & Ethylene glycol tetraacetic acid \\
\hline G protein & GTP-binding protein \\
\hline $\mathrm{GABA}_{\mathrm{A}}$ receptor & Gamma-amino butyric acid type $A$ receptor \\
\hline GCR & G protein-coupled receptor \\
\hline GDP & Guanosine disphosphate \\
\hline GDPßS & A non-phosphorylatable GDP analog \\
\hline Gpp(NH)p & A non-hydrolyzable GTP analog \\
\hline GTP & Guanosine trisphosphate \\
\hline GTP $\gamma \mathrm{S}$ & A non-hydrolyzable GTP analog \\
\hline HEPES & $N$-(2-hydroxyethyl)piperazine- $N^{\prime}$-(2-ethylsulfonic acid) \\
\hline $\mathrm{IC}_{50}$ & Half-maximal inhibitory concentration \\
\hline $\mathrm{IP}_{3}$ & Inositoltrisphosphate \\
\hline $\mathrm{K}_{\mathrm{ACh}}$ channel & Muscarinic-regulated $\mathrm{K}^{+}$channel \\
\hline LPA & Lysophosphatidate (lysophosphatidic acid) \\
\hline MAC & Minimal alveolar concentration \\
\hline MAP kinase & Mitogen-activated protein kinase \\
\hline mRNA & Messenger RNA \\
\hline N terminus & Amino terminus \\
\hline NMDA receptor & N-methyl-D-aspartate receptor \\
\hline NR1, NR2 & NMDA receptor subunit 1 and 2 \\
\hline $\mathrm{PA}$ & Phosphatidic acid \\
\hline PAF & Platelet aggregating factor \\
\hline $\mathrm{PIP}_{2}$ & Phosphatidylinositolbisphosphate \\
\hline PKC & Protein kinase $\mathrm{C}$ \\
\hline PLC & Phospholipase C \\
\hline RNA & Ribonucleic acid \\
\hline SiP & Sphingosine-1-phosphate \\
\hline $\mathrm{TXA}_{2}$ & Thromboxane $\mathrm{A}_{2}$ \\
\hline
\end{tabular}


INTRODUCTION

\section{CHAPTER 1}

Introduction and aims

Marcel E. Durieux 


\section{Introduction and aims}

\section{INTRODUCTION}

After more than a century of investigation, it appears that a common site of action for volatile and most non-volatile anesthetics may have been identified. The $G_{A B A}$ ligand-gated ion channel has for some time been recognized as the primary site of action for non-volatile drugs, such as barbiturates, benzodiazepines and steroid anesthetics. Propofol also appears to exert its primary action at this ionotropic receptor. Recent data indicate that volatile anesthetics, in clinically relevant concentrations, similarly enhance $G_{A B A}$ signaling, and a defined molecular target on the $\mathrm{GABA}_{\mathrm{A}}$ receptor has been localized. Thus, it appears that a unitary model of anesthesia may actually be the correct one. Ketamine, with its primary action at the NMDA glutamate receptor, appears one of the few exceptions to this model.

However, if the $\mathrm{GABA}_{\mathrm{A}}$ receptor were the only site of action for anesthetics, their side effects would be expected to be the same. This is obviously not the case. Therefore, if most anesthetics indeed induce anesthesia through the single mechanism of $\mathrm{GABA}_{\mathrm{A}}$ enhancement, their varying side effect profiles have to be explained through interactions with other systems. Particularly for volatile drugs this is not surprising, as these require very high (low millimolar) concentrations for clinical effect, and their lipophilic nature makes them likely to interact (possibly non-specifically) with a variety of lipophilic sites. In contrast, non-volatile anesthetics are usually therapeutically active in micromolar concentrations. They would be expected to interact with fewer sites, and likely in a specific manner.

Thus, one of the research challenges in the years to come will be to elucidate, at the molecular level, anesthetic sites of interaction in addition to the $\mathrm{GABA}_{\mathrm{A}}$ receptor. These secondary actions of anesthetics will define their unique side effect profile and can aid in the development of drugs with fewer adverse actions. This thesis reports some of our research in this area.

Clearly, the number of potential secondary molecular targets for anesthetics is overwhelming. Some have been probed in significant detail, many others have not been studied at all. In an effort to narrow the field, we focused on the physicochemical parameter that has driven anesthetic mechanisms research since the beginning of the century: the Meyer-Overton hypothesis. Most anesthetics are lipophilic, therefore lipophilic targets may be likely sites of secondary anesthetic interaction. One clear example of such lipophilic targets are $G$ protein-coupled receptors for lipophilic mediators. These include receptors for a variety of compounds relevant to anesthesiology and critical care, including the prostaglandin and leukotriene receptors, the thromboxane receptor and the platelet-activating factor receptor.

Study of interactions between anesthetics and $G$ protein-coupled receptors requires an appropriate model: one where receptors can be expressed functionally and in isolation, where they can be compared with each other in a similar setting, where volatile and non-volatile anesthetics can be administered in a reproducible manner, and where anesthetic effects on intracellular signaling can be studied in detail. Such a model was not established at the time, and we therefore developed one using Xenopus oocytes, already used widely for the investigation of G protein-coupled receptors, and used previously to study anesthetic effects on ion channels.

As an initial test of the system, we decided to focus on a lipid mediator receptor which we had found to be already expressed in oocytes: a novel receptor for the phospholipid lysophosphatidate (LPA). Although the (patho) physiology of the compound is as yet poorly de- 
scribed, it is known to induce (among other actions) platelet aggregation, contraction of smooth muscle (including vascular smooth muscle), changes in cellular morphology and mitosis. We felt that it would form a useful model for the study of anesthetic interactions with lipid mediator signaling. In addition, our studies would enhance the understanding of the physiology of LPA signaling.

\section{AIMS}

We hypothesized that different anesthetics interfere to different degrees with LPA signaling. These effects are localized at the membrane receptor rather than in the intracellular signaling pathways. Specifically, the goals of the study were to:

1. Establish the Xenopus oocyte model for the study of anesthetic effects on G proteincoupled receptors for lipophilic mediators, by (a) developing software for the efficient study of $G$ protein-coupled receptors in oocytes, and (b) determining the background presence of $G$ protein-coupled receptors in the model.

2. Describe the physiology of LPA signaling, as well as signaling by the related compound sphingosine-1-phosphate, in Xenopus oocytes.

3. Study the effects of several classes of anesthetics (volatile, non-volatile, and local) on LPA-mediated $\mathrm{Ca}^{2+}$ signaling in Xenopus oocytes.

This thesis reports the results of investigations planned to accomplish these Aims. It is organized as follows:

- Chapter 2 provides a review of our current understanding of anesthetic actions on membrane signaling molecules. The goal is not as much to be completely comprehensive, as well as to focus on those molecules where interactions appear to have a high likelihood of being relevant to anesthetic effects or side effects.

- Chapter 3 reviews LPA signaling. The main cellular effects of the compound and the molecular mechanisms behind those effects are discussed, and potential (patho)physiological roles for the compound are described.

- Chapter 4 is a review of the use of Xenopus oocytes for the study of G protein-coupled receptors. General properties of the oocyte are discussed, as well as the major ways in which the system can be used in experimental practice. This chapter will provide the reader with a framework to help interpret use of the model for the study of anesthetic interactions.

- Chapter 5 (Am J Physiol 263:C896-C900, 1992) describes the characterization of the LPA receptor in Xenopus oocytes, and provides an introduction to the methodology used throughout the remainder of the thesis.

- Chapter 6 (Am J Physiol 264:C1360-C1364, 1993) describes the characterization of a second lipid mediator $G$ protein-coupled receptor in the oocyte: that for the ligand sphingosine-1-phosphate. 


\section{CHAPTER 1}

- Chapter 7 (Comp Meth Progr Biomed 41:101-105, 1993) reports the development of a software system specifically designed to facilitate $\mathrm{G}$ protein-coupled receptor signaling in Xenopus oocytes.

- Chapter 8 (FEBS Lett 337:235-238, 1994) describes an endogenous response in the oocyte that potentially could confound experimental studies: a trypsin-induced $\mathrm{Ca}^{2+}$ activated $\mathrm{Cl}^{-}$current. In addition, the study is the first to use, in a practical investigation, the software described in Chapter 6.

- Chapter 9 (Anesth Analg 83:1090-1096, 1996) is the first of three chapters reporting anesthetic interactions of various classes of anesthetics with LPA signaling. This chapter describes the interaction between propofol and LPA signaling.

- Chapter 10 (Anesthesiology 86:660-669, 1997) reports the interactions of the volatile anesthetics halothane and isoflurane with LPA signaling.

- Chapter 11 (Anesthesiology 86:1112-1119, 1997) describes the differential effects of the local anesthetics lidocaine and bupivacaine on LPA signaling.

- Chapter 12 summarizes the reported results, and recommends further studies. 
ANESTHETIC ACTIONS

CHAPTER 2

Anesthetic actions on membrane signaling molecules

Marcel E. Durieux 


\section{Anesthetic Actions on Membrane Signaling Molecules}

\section{INTRODUCTION}

Despite more than a century of research, anesthetics are one of the very few drug classes for which a mechanism of action has not been definitively established. Research into this area during the first half of the century was largely guided by the strong correlation between lipid solubility and anesthetic potency described by Meyer ${ }^{1}$ and Overton. ${ }^{2}$ This relationship suggested a lipid site of anesthetic action, and the most logical lipid site for anesthetics to act would appear to be the cell membrane. However, despite the development of several elegant hypotheses, such as changes in membrane fluidity ${ }^{3-5}$ or volume, ${ }^{6}$ no clear membrane mechanism for anesthetic action has emerged. In retrospect, this is not completely surprising, as at $1 \mathrm{MAC}$ a concentration of approximately $70 \mathrm{mM}$ of anesthetic should be present at the lipid site of action, which would amount to one anesthetic molecule for each $2,000 \AA$, or one anesthetic molecule for each 60 lipid molecules. ${ }^{7}$ This suggests that the anesthetic would act merely as a minor membrane contaminant. Although by itself this does not rule out the possibility of a significant effect, it makes it less likely. Consistent with this calculation, large amounts of anesthetics are usually required to induce measurable membrane effects. Effects that occur at clinically relevant anesthetic concentrations can usually be mimicked by very small changes in temperature $\left(<1^{\circ} \mathrm{C}\right)$, which itself are without measurable anesthetic action. ${ }^{8}$

Whereas a large number of anesthetic molecules would be necessary to substantially change lipid membrane behavior, one anesthetic molecule could in theory modify the behavior of a single membrane protein significantly. For these and other reasons, interest has shifted over the last decades toward investigating anesthetic effects on protein molecules. The inhibition by anesthetics of firefly luciferase demonstrated the capability of anesthetics to interfere specifically with an isolated protein. ${ }^{9}$ Remarkably, this interaction takes place at concentrations similar to those relevant for anesthesia. In addition, some anesthetic actions were shown to be stereoselective, suggesting direct interactions with proteins. ${ }^{10}$ Subsequently, proteins have been shown to be common targets for anesthetics. 8

Most relevant for anesthetic action are of course the membrane signaling proteins, and it is to them that this review will be restricted. From an investigational point of view, they suffer a disadvantage: their position in the membrane makes it almost impossible to determine whether anesthetic effects are in fact due to direct interactions with the protein, or due to modification of their lipid environment. This issue has not yet been resolved, although stereospecificity studies strongly suggest a direct protein interaction.

It should be realized that a protein site of anesthetic action does not negate the MeyerOverton rule. In other words, even if anesthetics act primarily on a protein site, there is still a strong correlation with lipid solubility. Therefore, the protein site of interest is likely to be of a hydrophobic nature. For this reason, we hypothesized that the receptors for lipophilic ligands (which should have a lipophilic binding pocket) should be a likely target for anesthetic action.

In the following sections, our current understanding of anesthetic actions on the two major groups of cell signaling proteins will be discussed. Particular emphasis will be on interactions with volatile anesthetics, as their site of action is less clearly defined than is that of the injected drugs. References are largely to the more recent literature. 


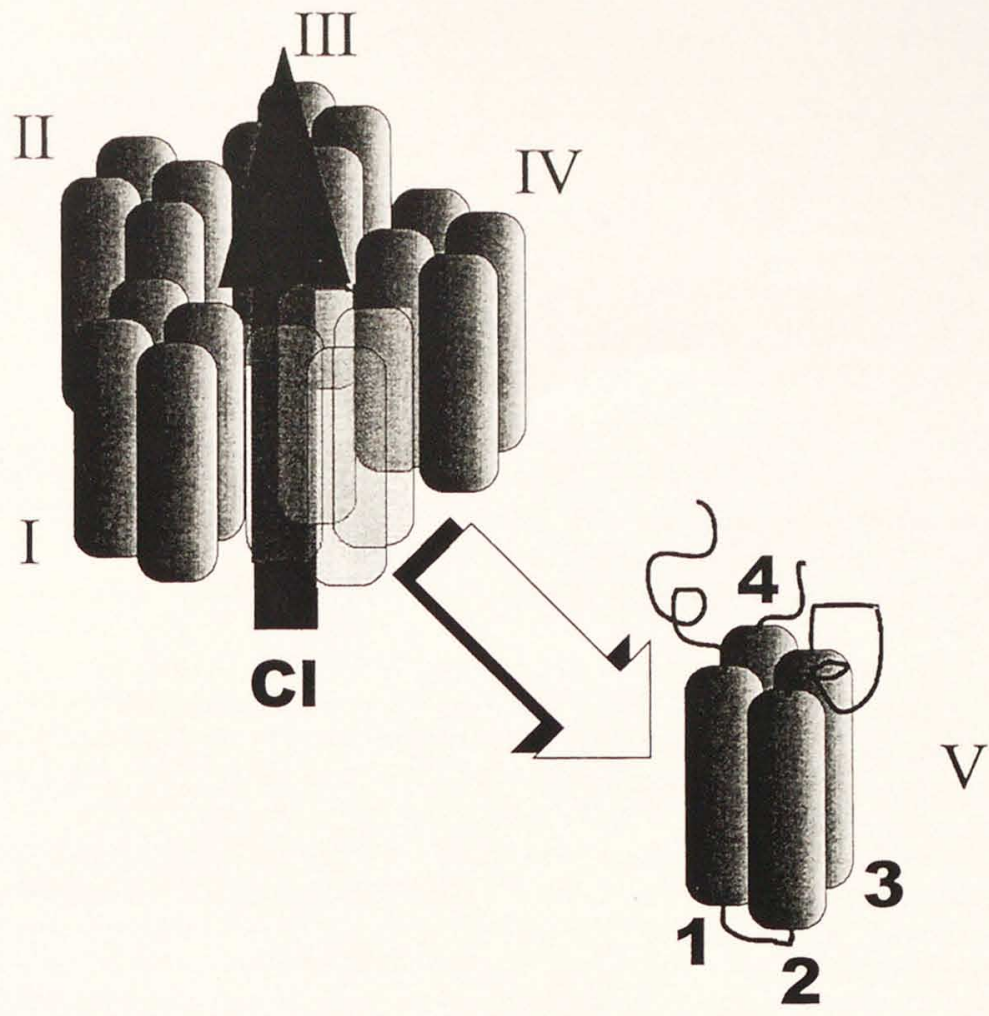

Figure 1. The $\mathrm{GABA}_{\mathrm{A}}$ receptor. The $\mathrm{GABA}_{\mathrm{A}}$ receptor-chloride channel protein complex is a heterooligomer composed of 5 subunits (I-V), including $\alpha, \beta, \gamma, \delta$ and $\rho$ polypeptides. Each subunit has 4 putative membrane-spanning domains (1-4, represented by cylinders), one or more of which contribute to the wall of the ion channel pore.

\section{ION CHANNELS}

As the major effect of anesthetics is on the central nervous system, and as neurons depend on ion fluxes to convey their electrical signals, ion channels have long attracted attention as potential sites of action for anesthetics.

Ionotropic receptors

The ionotropic receptors, or ligand-gated ion channels, comprise a superfamily of membrane molecules characterized by the presence of one or more ligand binding sites and an ion channel within the same macromolecular complex. Binding of ligand to the receptor induces a conformational change that leads to opening of the ion channel. Ionotropic receptors have in 
common with many voltage-gated ion channels that they consist of a number of molecular subunits, allowing for a large variety of functional receptors, the distribution of which across the brain has by and large not yet been established. Thus, studies of these receptors always run the risk of investigating a subunit composition that is not particularly relevant to the neuronal substrate of anesthetic action. Ionotropic receptors for excitatory neurotransmitters (such as the nicotinic acetylcholine receptor and the glutamate receptors) become permeable to cations (particularly $\mathrm{Ca}^{2+}$ and $\mathrm{Na}^{+}$) when activated; in contrast, receptors for inhibitory neurotransmitters (such as the $\mathrm{GABA}_{\mathrm{A}}$ and glycine receptors) become permeable to $\mathrm{Cl}$. In this section, anesthetic effects on $\mathrm{GABA}_{\mathrm{A}}$, NMDA glutamate, and nicotinic acetylcholine receptors will be reviewed.

\section{$G A B A_{A}$ receptors}

Of the ionotropic receptors, the $\mathrm{GABA}_{\mathrm{A}}$ receptor has received most attention as a site of anesthetic action. It has been well established as the primary target for most non-volatile anesthetics, such as the barbiturates, benzodiazepines, steroid anesthetics and propofol. In addition, alcohol interacts with this receptor, and recent evidence indicates that it is an important site of action for volatile anesthetics as well.

The receptor is thought to form a pentameric structure, composed of members from the five subunit families $(\alpha, \beta, \gamma, \delta$, and $\rho$, see Figure 1$) .{ }^{11}$ The subunits are structurally related: each consists of a single polypeptide with four putative membrane-spanning domains. As there are multiple subtypes of the subunits, the potential number of different $\mathrm{GABA}_{\mathrm{A}}$ receptors is staggering (up to 3000); in reality, however, it seems more likely that only approximately 500 types are expressed. ${ }^{11}$ The second transmembrane domain of each subunit is thought to contribute to the ion channel. The extracellular $\mathrm{N}$-terminus contains consensus sites for $\mathrm{N}$-linked glycosylation, and in some units the intracellular domains contain consensus sites for phosphorylation by protein kinase $\mathrm{A}$ and $\mathrm{C}$, as well as by tyrosine protein kinases. Other areas on the subunits form binding domains for a variety of compounds. The main GABA binding pocket is localized on the $\alpha$ subunit, as is the benzodiazepine binding site.

The evidence for effects of volatile anesthetics on $\mathrm{GABA}_{\mathrm{A}}$ receptors is compelling. A number of models have been used to study these actions, and virtually without exception they have shown enhancement of GABA signaling by relevant concentrations of anesthetic compounds. Harris et al, for example, demonstrated that halothane, isoflurane and sevoflurane enhanced flunitrazepam binding to the benzodiazepine receptor site by increasing ligand affinity. ${ }^{12}$ That these effects translate to functional changes in receptor behavior was shown by Lin et al, ${ }^{13}$ who expressed $\mathrm{GABA}_{\mathrm{A}}$ receptors in Xenopus oocytes and measured the effects of enflurane on their signaling properties. The anesthetic enhanced GABA-activated currents in a manner dependent on the subunit composition of the expressed channels. Longoni et al. have demonstrated similar effects of halothane on GABA receptors in rat brain cortical slices, ${ }^{14}$ and Harrison et al. reported comparable findings with isoflurane. ${ }^{15}$ Recently, sevoflurane has also been reported to modulate GABA signaling. ${ }^{16}$

Importantly, the effects of volatile agents on this receptor complex have been shown to be stereoselective, strongly suggesting a specific (i.e. protein) site of action. Flunitrazepam binding to benzodiazepine receptors is enhanced more by $\mathrm{S}(+)$ isoflurane than by $\mathrm{R}(-)$ isoflurane: $:^{17} \mathrm{EC}_{50}$ s were 0.44 and $0.88 \mathrm{mM}$, respectively. Potency of $\mathrm{Cl}^{-}$to increase flunitrazepam binding was increased 3.2 and 1.5 fold, respectively. Similar results were reported by Hall et al, who studied GABA-induced $\mathrm{Cl}^{-}$currents in cerebellar Purkinje cells. ${ }^{18}$ They observed a maximal 


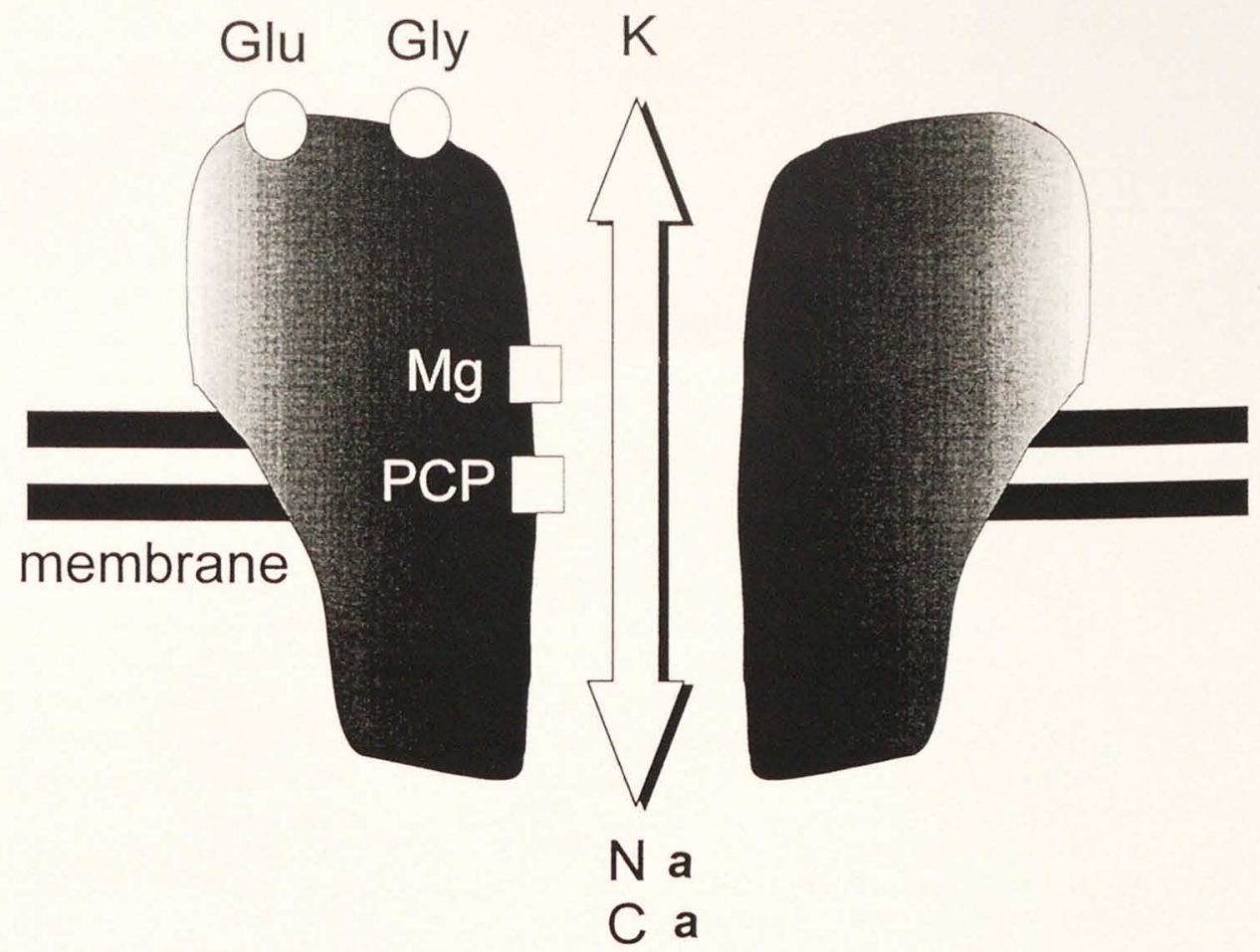

Figure 2. The NMDA receptor. Like the $\mathrm{GABA}_{\mathrm{A}}$ receptor complex, the NMDA receptor is a macromolecule with multiple binding and modulatory sites, including those for glutamate (or NMDA), glycine, phencyclidines (PCP) and $\mathrm{Mg}^{2+}$. In addition, the complex contains a cation channel permeable to $\mathrm{K}^{+}, \mathrm{Ca}^{2+}$ and $\mathrm{Na}^{+}$. The ion is positively modulated by glutamate and glycine, and negatively modulated by $\mathrm{PCP}$ and $\mathrm{Mg}^{2+}$.

stereoselective effect (approximately 2 fold) in favor of $\mathrm{S}(+)$ isoflurane at the $\mathrm{EC}_{50}$ concentration for general anesthesia $(310 \mu \mathrm{M})$. At lower anesthetic concentrations the stereoselectivity became less marked. Similar findings have been reported using rat brain synaptic microvesicles. ${ }^{19}$ The action of halothane on the $\mathrm{GABA}_{\mathrm{A}}$ receptor is also stereoselective, and associated with genetic loci different from those that distinguish between isomers of isoflurane. ${ }^{20}$ Thus, the anesthetics probably act through different sites.

In further support of a protein site of action are data demonstrating that the effect of anesthetics depends on the subunit composition of the $\mathrm{GABA}_{\mathrm{A}}$ receptors. As mentioned, this was already noted in the functional model employed by Lin et al. ${ }^{13}$ Harris et al. showed that expression of the $\beta 2$ subunit reduced the efficacy of both halothane and isoflurane in enhancing flunitrazepam binding. ${ }^{21}$ Of particular relevance are their findings that non-volatile anesthetics acting on the $\mathrm{GABA}_{\mathrm{A}}$ receptor (alphaxalone and pentobarbital) were affected differently, suggesting 
that volatile anesthetics act on separate sites. The $\alpha 6$ subunit appeared promising as a potential site of volatile anesthetic action, ${ }^{22}$ but recently it was shown that knockout mice lacking the $\alpha 6$ subunit have normal responses to volatile anesthetics. Mihic et al. ${ }^{23}$ reported recently that two specific amino acid residues in transmembrane domains 2 and 3 are critical for allosteric modulation of both $\mathrm{GABA}_{\mathrm{A}}$ and glycine receptors by alcohols and enflurane.

In summary, the data currently available suggest that the ionotropic $G A B A_{A}$ receptor is a likely site of action of anesthetics. In fact, as all anesthetics tested appear to enhance signaling at clinically relevant concentrations, it may well be the primary site of action for most of them (with the prominent exception of ketamine). However, if it were the only site, one would anticipate the clinical effects and side effects of these anesthetics to be similar. This, they clearly are not, and therefore other sites of activity must exist. Likely potential targets will be discussed briefly in the following sections.

\section{NMDA glutamate receptors}

Whereas the $\mathrm{GABA}_{\mathrm{A}}$ receptor is established as the primary site of action of most nonvolatile anesthetics and appears a likely primary site of action of volatile drugs as well, there is one clear exception: ketamine acts primarily on the NMDA glutamate receptor. It inhibits functioning of this receptor in a non-competitive manner, thus inhibiting excitatory neurotransmitter signaling. The different mode of action most likely explains the unusual clinical anesthetic effects of ketamine. Recent data suggest that other anesthetics also interact with the NMDA receptor to various degrees, making it worthy of consideration.

Glutamate acts on several classes of ionotropic receptors, as well as on metabotropic receptors. Three main types of ionotropic glutamate receptors are known, designated by their selective ligands: the $N$-methyl-D-aspartate (NMDA) receptors (Figure 2), the $\alpha$-amino-3-hydroxy5-methyl-4-isoxazole propionate (AMPA) receptors, and the kainate receptors. Often the latter are grouped together as non-NMDA receptors. NMDA receptors are more sensitive to anesthetics than non-NMDA receptors ${ }^{24}$ and have received most attention as anesthetic targets. Therefore, this discussion will be limited to NMDA receptors only.

NMDA receptors consist of two subunits, NR1 and NR2. Of the latter, 4 subtypes (A through $D$ ) are established. In addition, many alternative forms exist of both subunits, yielding a large variety of potential receptors. ${ }^{25}$ The NMDA receptor exhibits unusual pharmacologic behavior. It is characterized by high $\mathrm{Ca}^{2+}$ permeability (high single channel conductance and slow gating), voltage-dependent $\mathrm{Mg}^{2+}$ block, and a requirement for glycine as a co-agonist for channel activation. All these actions take place at the NR1 subunit. Together, these properties allow the receptor to play a key role in memory processes. ${ }^{26}$ However, the massive cellular influx of $\mathrm{Ca}^{2+}$ after glutamate excitation can have toxic effects on cells as well, and glutamate overstimulation (excitotoxicity), mainly mediated by NMDA receptors, is an established model of neuronal injury. Thus, inhibition of these receptors by anesthetics could not only account for part of clinical anesthesia, but be potentially neuroprotective as well.

As mentioned above, ketamine is well established as a non-competitive antagonist at the NMDA receptor. ${ }^{27-30}$ It is effective at clinical concentrations. In addition, it acts in a stereospecific manner, the $\mathrm{S}(+)$ form being approximately $2-3$ times as potent as the $\mathrm{R}(-)$ isomer, strongly suggesting that its action is specific. More recently, volatile anesthetics have similarly been shown to interact with NMDA receptors. Enflurane and halothane (0.2-0.3 mM) inhibit glutamate-stimulated ${ }^{45} \mathrm{Ca}$ uptake in rat brain microvesicles by as much as $60-80 \%{ }^{31}$ Interestingly, 
the anesthetics also diminish desensitization after prolonged exposure to NMDA. Both anesthetics, as well as methoxyflurane, chloroform and diethylether, have been shown to decrease glutamate-induced binding of the NMDA antagonist MK-801. ${ }^{32}$ Conversely, CNS administration of NMDA antagonists has modest anesthetic effects. For example, intrathecal application of NMDA antagonists reduces MAC of isoflurane by $10-20 \% .^{33}$

In agreement with an inhibitory action of anesthetics on NMDA signaling, anesthetics have been shown to ameliorate glutamate-induced excitotoxicity. A protective action of ketamine is well established, and the traditional contraindication of its use in neurotrauma patients is being reconsidered. Volatile anesthetics have similarly been shown to limit excitotoxic neuronal injury. ${ }^{34}$ In addition, much recent attention has focused on their ability to inhibit glutamate release, ${ }^{35-40}$ and enhance glutamate uptake. ${ }^{41,42}$ Together, these findings offer exciting new insight into the neuroprotective actions of anesthetics.

In brief, ketamine has its primary site of action on the NMDA receptor, and the volatile anesthetics have inhibitory effects on this system as well. Interactions with NMDA signaling may be relevant both to anesthetic effects, as well as to neuroprotective actions of the anesthetics.

\section{Nicotinic acetylcholine receptors}

The nicotinic receptors can be divided broadly in two classes: the muscle types and the neuronal types. Although neuronal nicotinic receptors are present in the CNS in much lower quantities than the glutamate receptors, they still play important roles, as is e.g. borne out by the syndrome of nicotine tolerance. (Interestingly, in insects this situation is reversed: there nicotinic receptors form the main CNS excitatory receptor, whereas neuromuscular transmission employs amino acid receptors. ${ }^{42,43}$ ) The neuronal nicotinic receptor is a pentameric structure, constructed out a variety of possible subunits. Whereas the muscle type consists of two $\alpha$ units, and one each of $\beta, \delta$ and $\varepsilon$ subunits (or $(\alpha)_{2} \beta \gamma \delta$ in fetal muscle), the neuronal receptors show a much greater variety of subtypes. ${ }^{44}$ At present it is not clear how these are combined in vitro. Of those receptors that do not bind $\alpha$-bungarotoxin, $6 \alpha$ and $4 \beta$ subunits have been cloned, and of the $\alpha$-bungarotoxin-binding receptors, several additional $\alpha$ subunits are known to exist. It is important to keep in mind that many combinations of two $\alpha$ subunits with or without other subunits provide functioning receptor/channel complexes. However, it is most times not clear if receptors with such a configuration actually exist in vivo.

From studies with the muscle-type receptor, it has become clear that the agonist acetylcholine binds to the $\alpha$ subunit, and that both $\alpha$ subunits require a bound acetylcholine molecule before the channel will open.

It has been well established that muscle nicotinic receptors are inhibited by anesthetics. ${ }^{45}$ The closely packed receptors in Torpedo membranes have been used to map the binding sites for ${ }^{14} \mathrm{C}$ halothane by photoaffinity labeling. ${ }^{46}$ Within the $\alpha$ subunit, more than $90 \%$ of label was found within the four transmembrane regions. As was the case with studies on the GABA $\mathrm{A}$ receptor, it appears that different anesthetics have different binding domains, as unlabeled halothane reduced labeling more than did isoflurane.

More recently, the neuronal subtypes have been shown to be even more sensitive to volatile anesthetics than muscle receptors, albeit in a complicated differential manner. Violet et al. recently expressed neuronal and muscle type nicotinic receptors in Xenopus oocytes and studied the effects of halothane, isoflurane, sevoflurane and propofol on their signaling. ${ }^{47}$ Neuronal re- 


\section{CHAPTER 2}

ceptors were significantly more sensitive than muscle receptors $\left(\mathrm{IC}_{50}\right.$ concentrations $10-35$ fold less). In fact, the receptors were found to be inhibited at concentrations below those required for general anesthesia. However, the sensitivity to anesthetic depends critically on subunit composition. For example, when expressed in Xenopus oocytes, $\alpha_{4} \beta_{2}$ neuronal receptors have been shown to be inhibited by isoflurane and propofol ( $\mathrm{IC}_{50} 85$ and $19 \mu \mathrm{M}$, respectively). ${ }^{48}$ In contrast, a monomeric $\alpha_{7}$ receptor was not affected by the anesthetics.

In view of the uncertainty about subunit compositions of these receptors in vivo, results from reconstitution experiments should be interpreted with caution. Nonetheless, it appears that at least some nicotinic receptors are inhibited by remarkably low concentrations of anesthetics, making them a likely target of anesthetic action.

Interesting
cant analgesia.

Interestingly, activation of neuronal nicotinic receptors has been shown to convey signifi-

Voltage-gated ion channels

The second major class of ion channels are those regulated by voltage rather than by ligand binding. In contrast to some of the ionotropic receptors, voltage-gated channels tend to be highly selective for specific ions, and they are therefore conveniently classified as to the permeant ion. The classes to be discussed here are the $\mathrm{Ca}^{2+}$ and $\mathrm{K}^{+}$channels, as these are channels which have been shown convincingly to be a target for anesthetics. $\mathrm{Na}^{+}$channels have generally been shown to be relatively resistant to anesthetic action (with the obvious exception of local anesthetics), although recent data indicates that neuronal $\mathrm{Na}^{+}$channels may be significantly more sensitive than the peripheral channels that are studied routinely. $\mathrm{Cl}^{-}$channels play several important roles, but have not been shown to be a significant target for anesthetics.

Voltage-gated ion channels show a bewildering diversity of types. Many of these have been defined by pharmacological means, in particular by the use of specific channel blockers. Molecular biology methods, however, have shown that many more clones exist than can be differentiated by pharmacologic means. The study of anesthetic interactions with all these subtypes will undoubtedly occupy electrophysiologists for years to come.

\section{$\mathrm{Ca}^{2+}$ channels}

Historically, $\mathrm{Ca}^{2+}$ channels have been classified in 5 groups, based on their electrophysiologic and pharmacologic characteristics. ${ }^{50} \mathrm{~T}$-type channels (low-voltage activated channels) activate at negative potentials $(-50$ to $-70 \mathrm{mV})$, whereas $\mathrm{L}, \mathrm{N}, \mathrm{Q}$ and $\mathrm{P}$ types (high-voltage activated) activate at more positive potentials $(-30 \mathrm{mV}$ and above). The four high-voltage activated types are differentiated on the basis of pharmacological criteria: L-type channels are blocked by dihydropyridines, $\mathrm{N}$-type channels by Conus geographicus toxin $\omega$-conotoxin GVIA, and P-type channels by Agenelopsis aperta toxins $\omega$-agatoxin IVA and FTX. Thus far, no specific blockers are available for Q-type channels.

Structurally, $\mathrm{Ca}^{2+}$ channels consist of several subunits. The primary one of these is the $\alpha_{1}$ subunit, which contains both the pore-forming region as well as the voltage sensor. This unit consists of four repeats of a structural motif of six transmembrane domains. This motif appears throughout the voltage-gated ion channel superfamily. Ancillary subunits $\left(\alpha_{2}, \beta, \gamma\right.$ and $\left.\delta\right)$ modulate the behavior of the $\alpha_{1}$ subunit. Cloning efforts have yielded cDNAs for $\alpha_{1}$ subunits with properties that match the main types of channels as described above. Thus, $\alpha_{1 \mathrm{~A}}$ is thought to en- 
code $\mathrm{P}$ and/or $\mathrm{Q}$ type channels, $\alpha_{1 \mathrm{~B}}$ encodes $\mathrm{N}$-type channels, and $\alpha_{1 C}$ and $\alpha_{1 D}$ encode L-type channels. Considering the modulatory influence of the ancillary subunits and the fact that the $\alpha_{1}$ subunits exist in several forms and splice variants, the functional variety of $\mathrm{Ca}^{2+}$ channels is likely to be significantly greater than that predicted by pharmacological and electrophysiological means alone.

Inhibitory effects of anesthetics on $\mathrm{Ca}^{2+}$ channels have been well described, although most studies have employed channels in native cells, and the exact subunit composition is therefore not known. Although these inhibitory effects are often modest, the essential role of voltagegated $\mathrm{Ca}^{2+}$ channels in regulating neurotransmitter release at the synapse makes even moderate actions of anesthetics relevant. The change in membrane potential resulting from an action potential arriving at the synaptic terminal leads to opening of $\mathrm{Ca}^{2+}$ channels, and it is the resulting $\mathrm{Ca}^{2+}$ influx into the synaptic terminal that forms the trigger for exocytosis of vesicles containing neurotransmitters. Anesthetics have been shown to inhibit release of neurotransmitters, in particular glutamate, presumably by blocking $\mathrm{Ca}^{2+}$ channels and inhibiting $\mathrm{Ca}^{2+}$ entry. ${ }^{35,38}$

Remarkably, it appears that $\mathrm{Ca}^{2+}$ channels are sensitive to virtually all anesthetics tested, which enhances the likelihood that this inhibition is part of anesthetic action per se, rather than a side effect of the compounds. Most studies have been performed on cardiac channels, ${ }^{51-54}$ and neuronal channels have only been investigated recently. Adrenal chromaffin cells have been used as a popular model for the study of neuronal channels, and anesthetics have been shown to inhibit $\mathrm{Ca}^{2+}$ channels present in these cells. For example, halothane, methoxyflurane, etomidate and methohexital block these channels, primarily by reducing probability of channel opening and increase in inactivation. ${ }^{55}$ Isoflurane inhibits calcium currents in neurons from sensorimotor cortex $^{56}$ as well as in pyramidal neurons from hippocampus. ${ }^{57}$ Both high-voltage activated and low-voltage activated channels appear sensitive. In fact, a recent report suggests that isoflurane (but not halothane) may block T-type channels more potently than it blocks L or N-type channels. ${ }^{58}$ These results suggest that anesthetic action is not dependent on the specific complement of ancillary subunits. In other words, anesthetics act probably on the $\alpha_{1}$ subunit. Initial studies using recombinant expression of defined channels are in progress, and these should be able to confirm this, as well as yield additional insight into the molecular mechanisms of action on these channels.

\section{$K^{+}$channels}

$\mathrm{K}^{+}$channels, which have as their primary role the regulation of the resting membrane potential, have been shown to exist in an enormous variety of forms. In fact, it is far from clear why so many different types are necessary to perform a relatively straightforward electrophysiologic task. These channels are structurally some of the most interesting ones. The classic $\mathrm{K}^{+}$channel (Shaker, originally cloned from Drosophila) has as its primary structure a single domain with six putative transmembrane regions, i.e. the structural analog of one-fourth of a $\mathrm{Ca}^{2+}$ channel. However, variants exist, including one subtype that consists of a single transmembrane domain only. ${ }^{59}$ Currently, the mammalian voltage-activated $\mathrm{K}^{+}$channels are divided into 6 subfamilies, with a total of approximately 20 main members. Of many of these, further subtypes have been cloned.

In addition to the voltage-activated $\mathrm{K}^{+}$channels, $\mathrm{K}^{+}$channels exist that are regulated by intracellular intermediates. Of particular interest are $\mathrm{K}_{\mathrm{ATP}}$ channels that are controlled by intracellular ATP concentrations. These are thought to play an essential role in the phenomenon of 
myocardial preconditioning, and volatile anesthetics, in particular isoflurane, have been shown to activate these channels directly. ${ }^{60-62}$ Anesthetics similarly inhibit $\mathrm{Ca}^{2+}$-activated $\mathrm{K}^{+}(\mathrm{BK})$ channels, ${ }^{63}$ as well as those $\mathrm{K}^{+}$channels regulated by muscarinic stimulation in heart $\left(\mathrm{K}_{\mathrm{ACh}}\right){ }^{64}$

Anesthetic interactions with voltage-gated $\mathrm{K}^{+}$channels have been studied only fairly recently, and with particular emphasis on cardiac $\mathrm{K}^{+}$channels; ${ }^{65}$ relatively little is known about their neuronal counterparts. Halothane and isoflurane decrease the open state probability of $\mathrm{K}^{+}$ channels in cerebral arterial cells. ${ }^{66}$ Ketamine and halothane have been shown to inhibit Kv2.1 $\mathrm{K}^{+}$channels from brain, expressed recombinantly in Xenopus oocytes. ${ }^{67}$ Interestingly, this inhibition was voltage dependent for halothane, but not for ketamine. Deletion of the C-terminus resulted in decreased sensitivity to both anesthetics.

\section{METABOTROPIC RECEPTORS}

The metabotropic receptors form a very large group of signaling molecules. They can be divided in several broad classes, the protein tyrosine kinase receptors and the $G$ protein-coupled receptors (GCRs). The protein tyrosine kinase receptors are large molecular complexes. Ligand binding induces activation of a phosphorylating enzyme activity in the intracellular segment of the molecule. As phosphorylation is one of the major mechanisms of cellular regulation, such receptors can have a variety of cellular effects. Many of these actions are relatively long-term, and possibly because of this reason anesthetic interactions with protein tyrosine kinase receptors have not been studied in significant detail. Therefore, this group will not be discussed further.

GCRs, in contrast, are much smaller. Ligand binding results in activation of an associated GTP-binding protein ( $G$ protein) that subsequently influences cellular processes. The number of GCRs is large, and still growing. Approximately a hundred defined receptors have been cloned, while in addition several dozens of clones exist that have the molecular characteristics of a GCR, but lack a known ligand (so-called orphan receptors). In addition, the olfactory epithelium expresses hundreds of GCRs, which are thought to mediate the sense of smell, and another large group, with unknown function, is expressed on sperm cells. Taken together, the superfamily has more than one thousand members.

All of these have similar molecular characteristics. They are generally several hundred to a thousand amino acids in length, and contain 7 stretches of 20 to 25 hydrophobic amino acids. These hydrophobic domains are thought to form $\alpha$ helices and traverse the membrane, thus anchoring the receptor to the cell (for this reason, the family is often referred to as the "seven transmembrane" family). The result of this arrangement is the creation of three intracellular and three extracellular loops. The amino terminus is located extracellularly, whereas the carboxyterminus is located intracellularly. The functional domains of the receptor have been elucidated in reasonable detail, despite the fact that no crystallographic detail is as yet available for the GCRs. It is thought that the 7 transmembrane domains arrange in a funnel-like structure, the inside of which forms the ligand binding domain. The intracellular domains, particularly the third intracellular loop and the $C$ terminus, bind to the $G$ protein. $G$ protein specificity can be determined by a remarkably small number of amino acids in the third intracellular loop, as elegantly demonstrated by mutation studies with the muscarinic receptors. ${ }^{68}$ In most of these receptors, the amino terminus carries one or more consensus sequences for glycosylation. In addition, phosphorylation sites are often present on the intracellular domains. 
$G$ proteins come in two classes: small (cytoplasmic) G proteins and heterotrimeric (membrane) $G$ proteins. Common to all is their mechanism of function. In their resting state, they bind a molecule of GDP. When activated (by a GCR in the case of heterotrimeric G proteins, and by another messenger in the case of cytoplasmic G proteins) this GDP is exchanged for a GTP molecule. The activated $G$ protein can now perform functions within the cell until it is inactivated when an intrinsic enzyme activity hydrolyzes the GTP to GDP. The critical point about this hydrolytic activity is that it is (molecularly speaking) very slow: on the order of seconds. As a result, brief (on the order of milliseconds) activation of a receptor can lead to more prolonged activation of the intracellular signaling machinery.

GCRs bind to heterotrimeric $G$ proteins, so called because they consist of three subunits: $\alpha, \beta$ and $\gamma$. Of these, the $\beta$ and $\gamma$ subunits are associated so tightly that for practical purposes they can be viewed as a single unit, often termed the $\beta \gamma$ subunit. The $\alpha$ subunit contains both the GDP-GTP binding domain as well as the hydrolytic activity, and was classically thought to be the "business end" of the molecule, with the $\beta \gamma$ subunit roaming freely and inactively, serving as an anchor and a sink of free $\alpha$ subunits. This view turns out to be incorrect: the $\beta \gamma$ subunit has activating functions as well. For example, it interacts with phospholipase $C \beta$ and the muscarinic $\mathrm{K}^{+}$channel. $\mathrm{G}$ protein binding to the associated receptor enhances receptor affinity for agonist. This phenomenon, known as GTP shift, is used as presumptive evidence that a receptor is $G$ protein coupled.

Several classes of heterotrimeric $G$ proteins exist, indicated by subscripts. The classical types are $G_{s}$ and $G_{i}$, which stimulate and inhibit, respectively, the enzyme adenylate cyclase, thereby leading to changes in cytoplasmic cAMP concentrations. $G_{q}$ proteins (and $G_{o}$ in brain) activate phospholipase $\mathrm{C}(\mathrm{PLC})$, and thereby induce the generation of inositoltrisphosphate $\left(\mathrm{IP}_{3}\right)$ and diacylglycerol (DAG) from phosphatidylinositolbisphosphate $\left(\mathrm{PIP}_{2}\right) . \mathrm{IP}_{3}$ acts on its own receptor/channel complex on intracellular $\mathrm{Ca}^{2+}$ storage sites, and induces release of $\mathrm{Ca}^{2+}$ from these sites, thereby raising intracellular $\mathrm{Ca}^{2+}$ concentrations. DAG activates protein kinase $\mathrm{C}$ (PKC) leading to phosphorylation of a variety of targets (including the receptors that initiated the cascade). In recent years, cloning efforts have shown each of these classes of $G$ proteins to consist of a number of members, but their functional differences are as yet poorly defined.

Despite the huge number of GCRs, only a few have received attention as potential anesthetic sites of action. Some of this lack of information is a result of the fact that these receptors are technically not easy to study: although the receptors are molecularly smaller than most channels and consist of a single subunit only, they are only one part of very complex signaling pathways. Therefore, it is not sufficient to determine the effects on the receptor itself: actions on intracellular signaling should be investigated as well.

The receptors for which most evidence exists as to interactions with anesthetics are the muscarinic acetylcholine receptors (Figure 3), and these findings will be discussed in some detail. In addition, we have studied effects of anesthetics on receptors for lipid mediators (LPA, thromboxane $\mathrm{A}_{2}{ }^{69}$ and prostaglandin $\mathrm{E}_{2}$ ). Results from experiments with LPA receptors will be described in subsequent chapters. Although occasional reports have suggested effects of anesthetics on other GCRs (such as serotonin receptors ${ }^{70}$ ), insufficient data exists to declare these systems anesthetic targets. Studies of anesthetic effects on intracellular signaling systems have yielded somewhat variable results, but it appears warranted to conclude that at clinical concentrations anesthetics affect neither intracellular $\mathrm{Ca}^{2+}$ nor cAMP signaling. ${ }^{8}$ 


\section{muscarinic receptor}

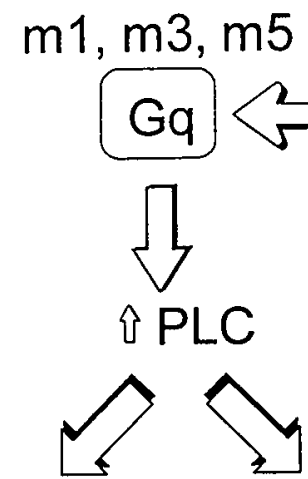

仓ิ IP3

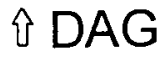<smiles>C1CCCCC1</smiles><smiles>C1CCCCC1</smiles>
i $\mathrm{Ca}$<smiles>C1CCCCC1</smiles>

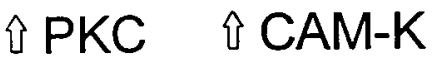

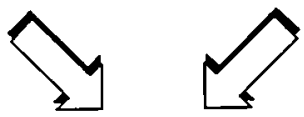

\section{î phosphorylation}

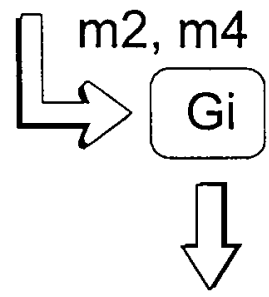

$\checkmark$ adenylate cyclase<smiles>C1CCCCC1</smiles>

\section{PKA}<smiles>C1CCCCC1</smiles>

$\checkmark$ phosphorylation

Figure 3. Muscarinic acetylcholine signaling. Muscarinic signal transduction is mediated by members of the $G$ protein-linked membrane receptor superfamily. $\mathrm{ml}, \mathrm{m} 3$ and $\mathrm{m} 5$ receptors couple to members of the $G_{q}$ family of $G$ proteins. Their main functional role is to cause activation of phospholipase $C$, resulting in liberation of inositoltrisphosphate $\left(\mathrm{IP}_{3}\right)$ and diacylglycerol $(\mathrm{DAG}) . \mathrm{IP}_{3}$ induces an increase in intracellular $\mathrm{Ca}^{2+}$ through release from intracellular stores, and, secondarily, activates $\mathrm{Ca}^{2+}$ dependent systems such as $\mathrm{Ca}^{2+} / \mathrm{calmodulin}$-dependent kinases. DAG directly activates protein kinase $C$ (PKC). $\mathrm{m} 2$ and $\mathrm{m} 4$ receptors couple to members of the $\mathrm{Gi}$ family of $\mathrm{G}$ proteins. Their main functions are to cause $\mathrm{G}_{\mathrm{i \alpha}}$-mediated activation of $\mathrm{K}^{+}$channels and to inhibit adenyl cyclase activity. Decreases in CAMP and cAMP-dependent protein kinase activity produce a state of decreased phosphorylation of effector systems. 
ANESTHETIC ACTIONS

\section{Muscarinic acetylcholine receptors}

Anesthetic effects on muscarinic receptors are well established. Aronstam and coworkers have published a series of papers reporting the effects of various anesthetics on muscarinic receptor binding. A summary of their findings has appeared in print as well. ${ }^{71}$ Several studies investigated the effect of halothane on agonist ${ }^{72}$ and antagonist ${ }^{13}$ binding. The conclusions drawn from this work were that (1) the anesthetic enhanced antagonist binding by slowing the rate of ligand dissociation; and (2) the anesthetic inhibited agonist binding (by $48 \%$ with $10 \%$ halothane).

The site of action of these effects was studied in more detail by investigating the interactions of anesthetics with $G$ protein functioning. ${ }^{72,73}$ As would be anticipated, the investigators found that addition of the non-hydrolyzable GTP analog Gpp(NH)p to the binding mixture resulted in decreased binding of muscarinic receptor agonist, i.e. GTP shift. They then determined the effect of halothane on this Gpp(NH)p-induced shift in the binding curve, and observed that the $\mathrm{Gpp}(\mathrm{NH}) \mathrm{p}$ concentration-response relationship was shifted to the right. In other words, a higher concentration of the GTP analog was necessary to induce a similar decrease in agonist binding. In the absence and presence of $5 \%$ halothane, the $\mathrm{IC}_{50}$ values for the inhibitory effect of $\mathrm{Gpp}(\mathrm{NH}) \mathrm{p}$ were 0.7 and $83 \mu \mathrm{M}$, respectively - a hundred-fold difference. These findings were interpreted as an ability of halothane to stabilize high-affinity $\mathrm{G}$ protein-receptor complexes.

Hence, it appears that halothane affects both receptor binding as well as receptor- $G$ protein interaction. In a subsequent study, the effect of the anesthetic on $G$ protein functioning - its ability to hydrolyze bound GTP - was investigated. Halothane was found not to inhibit binding of radiolabeled GTP analog to G proteins. However, the anesthetic blocked completely the stimulation of $\mathrm{G}$ protein GTPase activity induced by acetylcholine, with a half-maximal effect at the clinically relevant halothane concentration of $0.3 \mathrm{mM}$. The site of this effect was not determined. Largely similar findings were obtained with other anesthetics.

The conclusion to be drawn from these studies is that anesthetics may interfere with several components of the muscarinic signaling pathway. However, it should be kept in mind that (1) most times a mixture of muscarinic receptor subtypes was studied, (2) the anesthetics were administered in relatively high, and clinically unequal, concentrations, and (3) anesthetic effects on functional properties of the receptor- $G$ protein unit were not addressed specifically. Nonetheless, the results are in general agreement with those obtained later from functional studies.

Lin et al described the effects of enflurane on muscarinic acetylcholine receptors from extracted brain mRNA, ${ }^{74}$ and we have reported effects of several anesthetics on expressed muscarinic receptor clones. ${ }^{75,76}$ These studies were performed in Xenopus oocytes, a convenient model for such investigations. As will be described in more detail in Chapter 4 , in the oocyte, activation of $\mathrm{Ca}^{2+}$-signaling GCRs leads to generation of $\mathrm{IP}_{3}$ and release of intracellular $\mathrm{Ca}^{2+}$, which in turn opens an endogenous $\mathrm{Ca}^{2+}$-activated $\mathrm{Cl}^{-}$current, easily assayed by 2-electrode voltage clamp. Lin et al. found that enflurane $(2 \%)$ inhibited virtually completely currents induced by $100 \mathrm{nM}$ acetylcholine, but not $10 \mu \mathrm{M}$ acetylcholine. This suggests competitive components to the interaction. Similar to these findings, we observed that halothane, in clinically relevant concentrations, inhibited $\mathrm{ml}$ muscarinic signaling in this model. At a halothane concentration of approximately $0.3 \mathrm{mM}$, currents were depressed by $60 \%$. Studies with other expressed receptors and microinjection of intracellular mediators indicate that this anesthetic effect takes place at either the receptor or coupled G protein. 


\section{CHAPTER 2}

Studies with other anesthetics, however, have shown that these results can not necessarily be extrapolated. Isoflurane, at equipotent concentrations, was without effect on $\mathrm{m} 1$ signaling. ${ }^{76}$ Recently, we have shown that desflurane shows a biphasic effect: at lower concentrations (5\%) it enhances $\mathrm{ml}$ signaling, and at higher concentrations (10\%) it depresses it. ${ }^{76}$ The mechanism for this action is unclear at present, although we have shown that the anesthetic - like the others - is without effect on $\mathrm{IP}_{3}$ signaling. These findings are of significance, as the differences in anesthetic sensitivity imply that muscarinic inhibition is unlikely to underlie the anesthetic state per se. Instead, muscarinic inhibition is more likely to account for some of the specific side effects of clinically used anesthetics.

\section{REFERENCES}

1. Meyer TH: Theorie der Alkoholnarkose. Arch Exp Pathol Pharmacol 1899; 42: 109

2. Overton CE: Studien über die Narkose, zugleich ein Beitrag zur allgemeinen Pharmakologie. Jena, Fischer,G., 1901

3. Metcalfe JCSP, Burgen ASV: The proton relaxation of benzyl alcohol in erythrocyte membranes. Molec Pharmacol 1968; 4:87

4. Ueda I, Hirakawa M, Arakawa K, Kamaya $\mathrm{H}$ : Do anesthetics fluidize membranes? Anesthesiology 1986; 64: 67

5. Lee AG, Michelangeli F, East JM: Tests for the importance of fluidity for the function of membrane proteins. Biochem Soc Trans 1989; 17: 962

6. Miller KW, Paton WDM, Smith RA: The pressure reversal of general anesthetics and the critical volume hypothesis. Molec Pharmacol 1973; 9: 131

7. Dilger JP: Basic pharmacology of inhalational anesthetic agents. The Pharmacologic Basis of Anesthesiology. Edited by Bowdle TAHA, Kiefer MC, Horita A, Kharasch ED. New York, Churchill Livingstone, 1994, pp 497-521

8. Franks NP, Lieb WR: Molecular and cellular mechanisms of general anaesthesia. Nature 1994; 367: 607-614

9. Franks NP, Lieb WR: Do general anaesthetics act by competitive binding to specific receptors? Nature $1984 ; 310: 599-601$

10. Franks NP, Lieb WR: Stereospecific effects of inhalational general anesthetic optical isomers on nerve ion channels. Science 1991; 254: 427-430

11. Tyndale RF, Olsen RW, Toda H: GABAa receptors. Ligand- and voltage-gated ion channels. Edited by North RA. Boca Raton, CRC, 1995, pp 265-290

12. Harris $B$, Wong G, Skolnick P: Neurochemical actions of inhalational anesthetics at the GABAa receptor complex. J Pharmacol Exp Ther 1993; 265: 1392-1398

13. $\mathrm{Lin} \mathrm{LH}$, Whiting $\mathrm{P}$, Harris RA: Molecular determinants of general anesthetic action: role of GABAa receptor structure. J Neurochem 1993; 60: 1548-1553

14. Longoni B, Demontis GC, Olsen RW: Enhancement of gamma-aminobutyric acid A receptor function and binding by the volatile anesthetic halothane. J Pharmacol Exp Ther 1993; 266: $153-159$

15. Harrison NL, Kugler Л, Jones MV, Greenblatt EP, Pritchett DB: Positive modulation of human gamma-aminobutyric acid type $A$ and glycine receptors by the inhalation anesthetic isoflurane. Molec Pharmacol 1993; 44: 628-632 
16. Hirota K, Roth SH: Sevoflurane modulates both GABAa and GABAb receptors in area CA1 of rat hippocampus. Br J Anaesth 1997; 78: 60-65

17. Moody EJ, Harris BD, Skolnick P: Stereospecific actions of the inhalation anesthetic isoflurane at the GABAa receptor. Brain Res 1993; 615: 101-106

18. Hall AC, Lieb WR, Franks NP: Stereoselective and non-stereoselective actions of isoflurane on the GABAa receptor. Br J Pharmacol 1994; 112: 906-910

19. Quinlan JJ, Firestone S, Firestone LL: Isoflurane's enhancement of chloride flux through rat brain gamma-aminobutyric acid type A receptors is stereoselective. Anesthesiology 1995; 83: 611-615

20. Morgan PG, Usiak MF, Sedensky MM: Genetic differences affecting the potency of stereoisomers of isoflurane. Anesthesiology 1996; 85: 385-392

21. Harris BD, Wong G, Moody EJ, Skolnick P: Different subunit requirements for volatile and nonvolatile anesthetics at gamma-aminobutyric acid type A receptors. Molec Pharmacol $1995 ; 47: 363-367$

22. Sincoff R, Tanguy J, Hamilton B, Carter D, Brunner EA, Yeh JZ: Halothane acts as a partial agonist of the $\alpha 6 \beta 2 \gamma 2 S$ GABA $_{A}$ receptor. FASEB J 1996; 10: 1539-1545

23. Mihic SJ, Ye Q, Wick MJ, Koltchine W, Krakowski MD, Finn SE, Mascia MP, Valenzuela CF, Hanson KK, Greenblatt EP, Harris RA, Harrison NL: Sites of alcohol and volatile anesthetic action on GABAa and glycine receptors. Nature 1997; 389: 385-389

24. Narimatsu E, Tsai YC, Gerhold TD, Kamath SH, Davies LR, Kokolovsky M: A comparison of the effect of halothane on N-methyl-D-aspartate and non- $\mathrm{N}$-methyl-D-aspartate receptormediated excitatory synaptic transmission in the hippocampus. Anesth Analg 1996; 82: 843-847

25. Sprengel R, Seeburg PJ: Ionotropic glutamate receptors. Ligand- and voltage-gated ion channels. Edited by North RA. Boca Raton, CRC, 1996, pp 213-264

26. McBain CJ, Mayer ML: N-methyl-D-aspartic acid receptor structure and function. Physiol Rev 1994; 74: 723-753

27. Davies SN, Alford ST, Coan EJ, Lester RA, Collingridge GL: Ketamine blocks an NMDA receptor-mediated component of synaptic transmission in rat hippocampus in a voltagedependent manner. Neurosci Lett 1988; 92: 213-217

28. O'Shaughnessy CT, Lodge D: N-methyl-D-aspartate receptor-mediated increase in intracellular calcium is reduced by ketamine and phencyclidine. Eur J Pharmacol 1988; 153: 201209

29. Thomson AM, West DC, Lodge D: An N-methylaspartate receptor-mediated synapse in rat cerebral cortex: a site of action of ketamine? Nature 1985; 313:479-481

30. Yamamura T, Harada K, Okamura A, Kemmotsu O: Is the site of action of ketamine anesthesia the N-methyl-D-aspartate receptor? Anesthesiology 1990; 72: 704-710

31. Aronstam RS, Martin DC, Dennison RL: Volatile anesthetics inhibit NMDA-stimulated ${ }^{45} \mathrm{Ca}$ uptake by rat brain microvesicles. Neurochem Res 1994; 19: 1515-1520

32. Martin DC, Plagenhoef M, Abraham J, Dennison RL, Aronstam RS: Volatile anesthetics and glutamate activation of N-methyl-D-aspartate receptors. Biochem Pharmacol 1995; 49: 809-817

33. Ishizaki K, Yoshida N, Yoon DM, Yoon MH, Sudoh M, Fujita T: Intrathecally administered NMDA receptor antagonists reduce the MAC of isoflurane in rats. Can J Anaesth 1996; 43: 724-730 


\section{CHAPTER 2}

34. Bickler PE, Buck LT, Hansen BM: Effects of isoflurane and hypothermia on glutamate receptor-mediated calcium infux in brain slices. Anesthesiology 1994; 81: 1461-1469

35. MacIver MB, Mikulec AA, Amagasu SM, Monroe FA: Volatile anesthetics depress glutamate transmission via presynaptic actions. Anesthesiology 1996; 85: 823-834

36. Eilers $\mathrm{H}$, Bickler PE: Hypothermia and isoflurane similarly inhibit glutamate release evoked by chemical anoxia in cortical brain slices. Anesthesiology 1996; 85: 600-607

37. Bickler PE, Buck LT, Feiner JR: Volatile and intravenous anesthetics decrease glutamate release from cortical brain slices. Anesthesiology 1995; 83: 1233-1240

38. Miao N, Frazer MJ, Lynch C: Volatile anesthetics depress $\mathrm{Ca}^{2+}$ transients and glutamate release in isolated cerebral synaptosomes. Anesthesiology 1995; 83: 593-603

39. Schlame M, Hemmings HC: Inhibition by volatile anesthetics of endogenous glutamate release from synaptosomes by a presynaptic mechanism. Anesthesiology 1995; 82: 14061416

40. Patel PM, Drummond JC, Cole DJ, Goskowicz RL: Isoflurane reduces ischemia-induced glutamate release in rats subjected to forebrain ischemia. Anesthesiology 1995; 82: 9961003

41. Miyazaki H, Nakamura Y, Arai T, Kataoka K: Increase of glutamate uptake in astrocytes: a possible mechanism of action of volatile anesthetics. Anesthesiology 1997; 86: 1359-1366

42. Schloss P, Betz H, Schroder C, Gundelfinger E: Neuronal nicotinic acetylcholine receptors in Drosophila: antibodies against an $\alpha$-like and a non- $\alpha$-subunit recognize the same high affinity $\alpha$-bungarotoxin binding complex. J Neurochem 1991; 57: 1562

43. Schuster C, Ultsch A, Schloss P, Cox J, Schmidt B, Betz H: Molecular cloning of an invertebrate glutamate receptor subunit expressed in Drosophila muscle. Science 1991; 254: 114

44. Lindstrom JM: Nicotinic acetylcholine receptors. Ligand- and voltage-gated ion channels. Edited by North RA. Boca Raton, CRC, 1995, pp 153-175

45. Scheller M, Bufler J, Schneck H, Kochs E, Franke C: Isoflurane and sevoflurane interact with the nicotinic acetylcholine receptor channels in micromolar concentrations. Anesthesiology 1997; 86: 118-127

46. Eckenhoff RG: An inhalational anesthetic binding domain in the nicotinic acetylcholine receptor. Proc Natl Acad Sci USA 1996; 93: 2807-2810

47. Violet JM, Downie DL, Nakisa RC, Lieb WR, Franks NP: Differential sensitivities of mammalian neuronal and muscle nicotinic acetylcholine receptors to general anesthetics. Anesthesiology 1997; 86: 866-874

48. Flood P, Ramirez-Latorre J, Role L: Alpha 4 beta 2 neuronal nicotinic acetylcholine receptors in the central nervous system are inhibited by isoflurane and propofol, but alpha 7-type nicotinic acetylcholine receptors are unaffected. Anesthesiology 1997; 86: 859-865

49. Bannon AW, Decker MW, Holladay MW, Curzon P, Donnelly-Roberts D, Puttfarcken PS, Bitner RS, Diaz A, Dickenson AH, Porsolt RD, Williams M, ., Aneric SP: Broad-spectrum, non-opioid analgesic activity by selective modulation of neuronal nicotinic acetylcholine receptors. Science 1998; 279: 77-81

50. Stea A, Soong TW, Snutch TP: Voltage-gated calcium channels. Ligand- and voltage-gated ion channels. Edited by North RA. Boca Raton, CRC, 1995, pp 113-152

51. Pancrazio JJ: Halothane and isoflurane preferentially depress a slowly inactivating component of calcium channel current in guinea-pig myocytes. J Physiol 1996; 494: 92-103 


\section{ANESTHETIC ACTIONS}

52. Hirota K, Fujimura J, Wakasugi M, Ito Y: Isoflurane and sevoflurane modulate inactivation kinetics of $\mathrm{Ca}^{2+}$ currents in single bullfrog atrial myocytes. Anesthesiology 1996; 84: 377383

53. Baum VC, Wetzel GT, Klitzner TS: Effects of halothane and ketamine on activation and inactivation of myocardial calcium current. J Cardiovasc Pharmacol 1994; 23: 799-805

54. Takahashi H, Puttick RM, Terrar DA: The effects of propofol and enflurane on single calcium channel currents of guinea-pig isolated ventricular myocytes. Br J Pharmacol 1994; 111: 1147-1153

55. Charlesworth P, Pocock G, Richards CD: Calcium channel currents in bovine adrenal chromaffin cells and their modulation by anaesthetic agents. J Physiol 1994; 481: 543-553

56. Puli E, Hutcheon B, Reiner PB: Isoflurane inhibits calcium currents in neocortical neurons. Neurosci Lett 1994; 176: 63-66

57. Study RE: Isoflurane inhibits multiple voltage-gated calcium currents in neocortical neurons. Anesthesiology 1994; 81: 104-116

58. McDowell TS, Pancrazio JJ, Lynch C: Volatile anesthetics reduce low-voltage-activated calcium currents in a thyroid C-cell line. Anesthesiology 1996; 85: 1167-1175

59. Chandy KG, Gutman GA: Voltage-gated $\mathrm{K}^{+}$channels. Ligand- and voltage-gated ion channels. Edited by North RA. Boca Raton, CRC, 1995, pp 1-72

60. Kersten JR, Schmeling TJ, Hettrick DA, Pagel PS, Gross GJ, Warltier DC: Mechanism of myocardial protection by isoflurane. Role of adenosine triphosphate-regulated potassium $\left(\mathrm{K}_{\mathrm{ATP}}\right)$ channels. Anesthesiology 1996; 85: 794-807

61. Crystal G, Gurevicius J, Salem MR, Zhou X: Role of adenosine triphosphate-sensitive potassium channels in coronary vasodilation by halothane, isoflurane, and enflurane. Anesthesiology $1997 ; 86: 448-458$

62. Han J, Kim E, Ho WK, Earm YE: Effects of volatile anesthetic isoflurane on ATP-sensitive $\mathrm{K}^{+}$channels in rabbit ventricular myocytes. Biochem Biophys Res Commun 1996; 229: 852-856

63. Denson DD, Worrell RT, Eaton DC: The possible role for phospholipase A2 in the action of general anesthetics. Am J Physiol 1996; 270: C636-C644

64. Magyar J, Szabo G: Effects of volatile anesthetics on the $G$ protein-regulated muscarinic potassium channel. Molec Pharmacol 1996; 50: 1520-1528

65. Park WK, Pancrazio JJ, Suh CK, Lynch C: Myocardial depressant effects of sevoflurane. Mechanism and electrophysiologic actions in vitro. Anesthesiology 1996; 84: 1166-1176

66. Eskinder H, Gebremedhin D, Lee JG, Rusch NJ, Supan FD, Kampine JP, Bosjnak ZJ: Halothane and isoflurane decrease the open state probability of $\mathrm{K}^{+}$channels in dog cerebral arterial muscle cells. Anesthesiology 1995; 82: 479-490

67. Kulkarni RS, Zorn LJ, Anatharam V, Bayley H, Treistman SN: Inhibitory effects of ketamine and halothane on recombinant potassium channels from mammalian brain. Anesthesiology 1996; 84: 900-909

68. Lechleiter J, Hellmiss R, Duerson K, Ennulat D, David N, Clapham D, Peralta E: Distinct sequence elements control the specificity of $G$ protein activation by muscarinic acetylcholine receptor subtyypes. Embo J 1990; 9: 4381-4390

69. Hoenemann CW, Nietgen GW, Podranski T.A.Chan C.K., Durieux ME: Influence of volatile anesthetics on thromboxane $\mathrm{A}_{2}$ signaling. Anesthesiology 1998; 88: 440-451 


\section{CHAPTER 2}

70. Lin LH, Leonard S, Harris A: Enflurane inhibits the function of mouse and human brain phosphatidylinositol-linked acetylcholine and serotonin receptors expressed in Xenopus oocytes. Molec Pharmacol 1993; 43: 941-948

71. Aronstam RS, Dennison RL: Anesthetic effects on muscarinic signal tranduction. Int Anesthesiol Clin 1989; 27: 265-272

72. Dennison RL, Anthony BL, Narayanan TK, Aronstam RS: Effects of halothane on high affinity agonist binding and guanine nucleotide sensitivity of muscarinic acetylcholine receptors from brainstem of rat. Neuropharmacology 1987; 26: 1201-1205

73. Aronstam RS, Anthony BL, Dennison RL: Halothane effects on muscarinic acetylcholine receptor complexes in rat brain. Biochem Pharmacol 1986; 35: 667-672

74. Lin LH, Leonard S, Harris A: Enflurane inhibits the function of mouse and human brain phosphatidylinositol-linked acetylcholine and serotonin receptors expressed in Xenopus oocytes. Molec Pharmacol 1993; 43: 941-948

75. Durieux ME: Halothane inhibits signaling through $\mathrm{ml}$ muscarinic receptors expressed in Xenopus oocytes. Anesthesiology 1995; 82: 174-182

76. Nietgen GW, Hoenemann CW, Chan CK, Kamatchi GL, Durieux ME: Volatile anaesthetics have differential effects on recombinant $\mathrm{ml}$ and $\mathrm{m} 3$ muscarinic acetylcholine receptor function. Br J Anaesth 1998; 81: 569-577 


\section{CHAPTER 3}

\section{Lysophosphatidate signaling}

Marcel E. Durieux 


\section{CHAPTER 3}

\section{Lysophosphatidate signaling}

This chapter will review our current state of understanding of signaling by the compound lysophosphatidate (LPA). LPA is a highly intriguing compound: it is generated in large amounts during a process as common as platelet aggregation, its receptor is present almost ubiquitously, its cellular effects are varied and pronounced. At the same time we are still at a loss as to the physiologic or pathophysiologic role of the compound, and we are not in the possession of adequate pharmacologic tools such as highly selective antagonists or a receptor clone (although both have been reported, they are not yet accepted by the scientific community). From the viewpoint of anesthetic interactions the compound is of interest as inhibition of several of its actions (e.g. platelet aggregation and vascular smooth muscle contraction) could potentially have detrimental results in the surgical patient. The presence of an LPA receptor in Xenopus oocytes provides a model system where effects on receptor as well as intracellular pathways can be probed in detail.

The contents of this chapter are modified and updated from a book on this topic published by the author in $1995 .^{1}$

\section{STRUCTURAL PROPERTIES OF LPA}

LPA (1-acyl-2-sn-glycero-3-phosphate) is the simplest phospholipid known (see Chapter 6, Figure 1). For many years, the compound had been considered only as a constituent of lipid bilayer membranes and an intermediate in phospholipid metabolism, where it acts as a precursor in the synthesis of phosphatidic acid. ${ }^{2}$

LPA consists of a glycerol backbone with an acyl chain substituted in the $s n-1$ position, a hydroxyl group in the $s n-2$ position and a phosphate group in the $s n-3$ position. As the length and saturation of the acyl chain can vary, it is technically not correct to speak of LPA per se. Rather, there is a family of lysophosphatidic acids, and the composition of the acyl chain determines partially the potency of the compound. In fact, recent findings appear to indicate that LPA is only one member of a family of lipid phosphoric acid mediators, possibly acting on related receptors. Other members of this group include sphingosine-1-phosphate, for which a signaling role is established, and amantadine-1-phosphate. Lynch et al. have proposed that phosphorylated $\mathrm{N}$-acyl ethanolamines may occur naturally. ${ }^{3}$

The physicochemical properties of LPA have been studied in surprisingly little detail. Nonetheless, this information is of significance, as particularly the solubility properties of LPA are unusual for a signaling molecule and are relevant for defining the putative physiologic role of LPA. As an amphiphilic compound, LPA will form micelles in aqueous solutions at higher concentrations. The compound has a critical micellar concentration of approximately $1.3 \mathrm{mM}$ in 0.1 $\mathrm{M} \mathrm{NaCl}, 10 \mathrm{mM}$ HEPES buffer (pH 7.4). ${ }^{4}$ Nonetheless, several studies have shown only modest influence of the macromolecular form of LPA on its functional activity. 5 The compound binds $\mathrm{Ca}^{2+}$ avidly, in a 1:1 molar ratio, and aqueous LPA solutions become visibly turbid when $\mathrm{Ca}^{2+}$ is added. ${ }^{4} \mathrm{Ca}^{2+}$-induced turbidity can be prevented by the presence of bovine serum albumin (BSA), which also binds LPA, as discussed below.

It is of importance to mention that LPA, at concentrations that induce its pharmacologic effects, is not lytic to cells. This is in contrast to other phospholipids, in particular lysophosphatidylcholine, which has pronounced detergent properties. Jalink et al. showed conclusively that LPA concentrations greater than $1 \mathrm{mM}$ did not induce leakage of indo-1 out of cells, whereas 
lysophosphatidylcholine readily permeabilized cells at 10 -fold lowed concentrations. ${ }^{4}$ Although this result may not be extrapolated to all models (e.g. Dictyostelium discoideum is lysed by 200 $\mu \mathrm{M} \mathrm{LPA}^{6}$ ), $100 \mu \mathrm{M}$ LPA should be safe for most cell types.

The structure-activity relationship of LPA is being actively investigated. It has been known for a considerable amount of time that activity of the compound is closely related to structure of the phosphate and hydroxyl moieties: virtually any modification of this structure inactivates the compound completely. For example, neither phosphatidic acid (with an $s n-2$ hydrocarbon chain) or lysophosphatidylcholine (with a choline group attached to the phosphate) are able to elicit $\mathrm{Ca}^{2+}$ transients in most cell types. ${ }^{4}$ The acyl tail also has an influence on activity, but structural changes are tolerated better. For example, optimal potency of LPA for increasing rat blood pressure was obtained with a chain length of 16 and 2 or 3 double bonds. ${ }^{7}$ Similar findings were obtained in smooth muscle contraction ${ }^{8}$ and platelet aggregation ${ }^{9}$ assays. Lynch et al. have reported the relationship between total backbone length and activity of LPA, and found optimal activity at a chain length of 24-25 atoms. ${ }^{3}$

\section{SIGNALING PROPERTIES OF LPA}

LPA exhibits a profound array of actions on a variety of cellular systems. Indeed, the ubiquity of responsiveness to LPA has hindered efforts to clone the receptor for the compound. In this section, a brief overview will be provided of the main cellular effects of LPA. It should be noted that the vast majority of these studies were performed in cultured, immortalized cell lines. It is possible that the immortalized state or other selection procedures inherent in cell culture (such as adhesiveness) may be related to the ubiquitous LPA response.

\section{Smooth muscle}

Many of the early studies of LPA signaling were performed in smooth muscle. One of the initial observations of a physiologic effect of LPA was reported in 1978, when Tokumura described a transient pressor response in rats after the intravenous injection of crude soybean lecithin. ${ }^{10}$ The active compound was isolated and found to be LPA. ${ }^{7}$ The effects were species dependent: in rats and guinea pigs the compound was hypertensive, but in cats and rats it was hypotensive. These differences were shown by Schumacher to result from a species-specific effect on platelet aggregation: ${ }^{11}$ in species where LPA activates platelets the resulting aggregates are trapped in the pulmonary circulation, and the sudden increase in pulmonary vascular resistance induces circulatory collapse. In contrast, in those animals where LPA does not appreciably aggregate platelets, an increase in blood pressure is observed as a result of direct smooth muscle contractile effects of the compound.

A number of other smooth muscle preparations have been used to study the contractile actions of LPA. LPA was found to contract uterine smooth muscle, ${ }^{8}$ as well as intestinal smooth muscle. ${ }^{12,13}$ In all these systems, potency depended on chain length and saturation in the manner described in the previous section. Interestingly, despite the fact that the original observations of LPA's action on smooth muscle derived from the vasculature, it was not until recently that direct observations of the cerebral circulation demonstrated a contractile action of LPA on the vasculature. ${ }^{14}$ In pial arterioles a modest contraction (up to $15 \%$ ) was induced by the compound. We have shown recently that LPA has a more profound contractile action on larger cerebral arteries 


\section{CHAPTER 3}

(unpublished observations). It is unfortunate that this area has been relatively neglected, as a role for LPA in the vasculature appears likely.

\section{Mitogenic effects}

In 1986, Moolenaar published a seminal paper reporting that phosphatidic acid (PA) acted as a growth factor for fibroblasts. ${ }^{15}$ Since that time it has been shown that many commercial PA sources contain significant amounts of LPA. ${ }^{16,17}$ As LPA has been shown to be a more potent mitogen than $\mathrm{PA}^{18}$ it is likely that LPA was responsible for the growth promoting actions of PA in the original studies. In addition to being mitogenic, the compound induced protooncogene expression after $1 \mathrm{~h}$ of treatment. The cells in these experiments were serum-starved before being tested. Serum itself was approximately as potent a mitogen as the combination of $\mathrm{PA}$ and insulin. In view of later studies, it seems likely that this effect is due to the presence of LPA on serum albumin, as discussed below.

The mitogenic action of LPA has since been shown to be highly specific. Van Corven et al. tested a large variety of phospholipids and related compounds for mitogenic activity, and found only PA and LPA to be active. ${ }^{19}$ Specifically, they could demonstrate the importance of the LPA backbone for cellular activity. Changes in the phosphate group (e.g. lysophosphatidylcholine, lysophosphatidylethanolamine, lysophosphatidylinositol), changes in the fatty acid chain linkage (e.g. lyso-platelet-activating factor) and changes in the $s n-2$ position of the glycerol backbone (e.g. platelet-activating factor) lead to inactive compounds. LPA-induced proliferation is sensitive to pertussis toxin, suggesting that a $G_{i}$ protein is involved in the signal transduction pathway. ${ }^{19}$

\section{Intracellular $\mathrm{Ca}^{2+}$ release}

In the 1986 study by Moolenaar, PA (possibly contaminated with LPA) was also shown to induce release of $\mathrm{Ca}^{2+}$ from intracellular stores in A431 human carcinoma cells. ${ }^{15}$ This effect was specific for the compound and not mimicked by several structurally related molecules. The action of (L)PA was shown to be associated with increases in $\mathrm{IP}_{3}$, suggesting that the compound induces phospholipase $\mathrm{C}$ activation. In a more detailed investigation, Jalink demonstrated that LPA itself also increases intracellular $\mathrm{Ca}^{2+}$ levels in an $\mathrm{IP}_{3}$-dependent manner. ${ }^{4}$ This effect was shown not to be sensitive to pertussis toxin (and therefore most likely mediated by a $G_{q}$ protein). However, the action could be blocked by phorbol ester treatment. The effect was again highly specific.

The ability of LPA to induce $\mathrm{Ca}^{2+}$ transients has been evaluated in a large variety of cell types, and has been found to be present in virtually every cell type tested. Of relevance to the present report, Xenopus laevis oocytes also responded to LPA with intracellular $\mathrm{Ca}^{2+}$ transients, which in this model induce a $\mathrm{Ca}^{2+}$-activated $\mathrm{Cl}^{-}$current through endogenous channels. Only very few cell types have been found to be unresponsive. These unresponsive cells include fresh human neutrophils, mast cells, Jurkat T cells, monocytes, peripheral blood lymphocytes and K562 cells (although a few contradictory reports exist). Interestingly, all these cells are of hematopoietic lineage, and most of them are part of the immune system. Platelets, on the other hand, do respond to LPA with a $\mathrm{Ca}^{2+}$ transient. 


\section{LYSOPHOSPHATIDATE SIGNALING}

\section{Platelet aggregation and LPA generation by platelets}

Schumacher et al. demonstrated in 1979 that a factor present in serum "aged" for 18 to 24 $h$ induced platelet aggregation in vivo." The compound was tentatively defined as LPA, and LPA was shown to have the same effects. The effect is concentration-dependent as well as species-dependent: rat, rabbit and guinea pig platelets do not respond to the compound, feline platelets aggregate at a threshold of approximately $0.1 \mu \mathrm{g} / \mathrm{ml}$, and human platelets aggregate at approximately $6-10 \mu \mathrm{g} / \mathrm{ml}$.

Later studies have shown this platelet-aggregating activity of LPA to be $\mathrm{Ca}^{2+}$ - and $\mathrm{Mg}^{2+}-$ dependent, to be optimal at a $\mathrm{pH}$ of 7.50 and to be enhanced by the presence of fibrinogen. LPA enhances ADP-induced platelet aggregation as well. ${ }^{16,20}$ Its signaling pathway is separate from that of PAF. ${ }^{21,22}$ Watson et al. have demonstrated that LPA acts at an extracellular site on the platelet. $^{23}$

Not only does LPA induce platelet aggregation, it is also generated by activated platelets. ${ }^{24}$ This LPA, mostly of the palmitoyl, stearoyl or arachidonyl variety, ${ }^{25}$ appears to be released extracellularly. ${ }^{26}$ Because of this release (and possibly because of generation by stimulated neutrophils [Durieux ME: unpublished observations]) LPA is present in micromolar concentrations in serum. ${ }^{26}$ In serum, it is bound tightly to serum albumin ${ }^{27}$ at a relative LPA:albumin ration of $2: 1 .^{28}$ In fact, many of the cellular effects of serum may be due to LPA. For example, Moolenaar, in his paper describing the mitogenic actions of (L)PA, noted already that serum induced similar actions. Serum-induced sensitization of cAMP stimulation in atrocytoma cells, ${ }^{29,30}$ neurite retraction in nerve growth factor-stimulated PC12 cells, ${ }^{31,32}$ and Sp2 shape changes ${ }^{33}$ are examples of serum effects due to the presence of LPA. It is likely, therefore, that LPA is one of the main active factors in the serum routinely used to supplement cell culture. Some LPA is also present in plasma. ${ }^{34}$

\section{Cytoskeletal effects}

As mentioned above, LPA has dramatic effects on the shapes of some cell types: neurite retraction is observed in nerve growth factor-stimulated $\mathrm{PC} 12$ cells, ${ }^{32}$ and even more rapid rounding has been observed in neuroblastoma cells. ${ }^{35}$ Similar findings were reported in glioma cells. ${ }^{36}$ In addition, LPA reverses CAMP-induced stellation in BHK21 cells ${ }^{37}$ and spinal cord astrocytes, ${ }^{38}$ and induces shape changes in a variety of other fibroblasts lines. Of particular interest may be a recent report of LPA-induced contraction in Dupuytren's fibroblasts. ${ }^{39}$ Although the mechanisms underlying these effects are likely to be varied, one common pathway may be effects of LPA on the cytoskeleton. Neurite retraction in NG108-15 cells, for example, is blocked by cytochalasin $B .^{40}$ In fact, LPA has been shown to induce actin stress fiber assembly. In an effort to determine the factor(s) in serum responsible for maintenance of the actin stress fiber system, Ridley and Hall determined activities of a number of growth factors in serum, and found LPA to be the one most able to mimic the serum action. ${ }^{41}$ Similar findings have been reported by $\mathrm{Ha}$ and Exton. ${ }^{42}$

In addition, LPA is known to affect several adhesion molecules. Both LPA and PA enhance the interaction between fibronectin and integrins, ${ }^{43}$ although this effect could be observed in lipid vesicles only, not in platelet membranes. LPA enhancement of binding to integrins may be a common property, as similar findings have been reported in other systems. For example, Checovich and Mosher showed that binding of fibronectin to MG-63 osteosarcoma cells is en- 


\section{CHAPTER 3}

hanced in a dose-dependent manner by LPA. ${ }^{44}$ This appeared due to an increase in the number of fibronectin binding sites, rather than a change in affinity. Recent evidence suggests that Rho, which is activated by LPA, is involved in signaling downstream of integrins. ${ }^{45}$

In view of LPA's action on adhesion, it is of interest that most of the cell types found to be unresponsive to LPA are part of the hematopoietic system, and therefore do not adhere under normal circumstances.

These cytoskeletal effects may explain in part the findings of modulation by LPA of tumor invasion, a process highly dependent on adhesion and cytoskeletal action. For example, LPA induces invasion of AH130 hepatoma cells (MM1 clone). ${ }^{46}$

\section{Non-mammals}

All the effects described thus far were on mammalian cells. However, LPA responses are not limited to mammals. In Xenopus laevis oocytes LPA induces $\mathrm{Ca}^{2+}$-activated $\mathrm{Cl}^{-}$currents. ${ }^{28,47}$ $48,48,49$ This will be described in more detail in the remainder of this thesis.

In addition, LPA has been shown to be a chemoattractant for Dictyostelium discoideum amoebae. ${ }^{6}$ The compound is approximately half as efficient an attractant as cAMP, the classic chemoattractant for this system. LPA-induced chemotaxis occurs over the concentration range of 0 to $2 \mu \mathrm{M}$. These findings suggest that LPA signaling is an evolutionary ancient system, spread widely through the animal kingdom. Thus, LPA signaling may have a high survival value.

\section{LPA SIGNALING}

The remarkable variety of cellular effects induced by LPA appears to suggest that the compound may act in a non-specific manner. However, data indicating that the compound is not lytic in cells, ${ }^{4}$ that it does not act when applied intracellularly, ${ }^{23,47,48}$ and that a large variety of related compounds are without effect indicate that LPA has a specific, extracellular site of action. Thus, one would expect to find evidence for a membrane receptor system. Unfortunately, ligand binding assays with LPA have thus far been found to be poorly reproducible, ${ }^{50,51}$ probably because of excessive non-specific membrane binding of the lipophilic compound, as well as metabolism. The ubiquitous presence of LPA responses in cells commonly used for expression cloning and the absence of a dependable binding assay have greatly hampered efforts to clone the LPA receptor. Although several cDNA clones have been suggested to encode LPA receptors, none of them can at the time of writing be conclusively assigned that role. Thus, most evidence for the existence of an LPA receptor is relatively indirect. In contrast, the intracellular pathways influenced by LPA are much better defined. In this section, I will briefly review these data.

\section{Evidence for an LPA receptor}

Evidence for the existence of an LPA receptor system is as follows: (1) LPA acts extracellularly; (2) some responses to LPA are sensitive to pertussis toxin; (3) LPA signaling is affected by direct activators and inactivators of $G$ proteins; and (4) a photoaffinity analog labels an LPA binding protein in the plasma membrane.

As mentioned before, intracellular application of LPA is without effect. Watson et al. generated LPA intracellularly in platelets from didecanoylglycerol, and found it not to induce 
aggregation. ${ }^{23}$ In Xenopus oocytes, we $\mathrm{e}^{48}$ and others ${ }^{47}$ have shown that intracellular application of LPA does not induce $\mathrm{Ca}^{2+}$-activated $\mathrm{Cl}^{-}$currents. In addition, LPA microinjected into N1E-115 cells does not induce shape changes, whereas extracellularly applied LPA does. ${ }^{35} \mathrm{La}^{3+}$, which interacts strongly with negatively charged phospholipids, completely blocks the LPA-induced $\mathrm{Ca}^{2+}$ signal in fibroblasts, even when added after initiation of the response. ${ }^{4} \mathrm{As} \mathrm{La}^{3+}$ is virtually impermeable in most cell types, the ability of the compound to terminate LPA actions must take place extracellularly. Similarly, bovine serum albumin, which binds LPA, is able to reverse LPA-induced platelet aggregation. ${ }^{22}$ Thus, the site of action of LPA is likely to be extracellular.

The mitogenic activity of LPA is inhibited by pertussis toxin, ${ }^{19}$ strongly suggesting a $G$ protein-coupled pathway. LPA inhibition of adenylate cyclase is also inhibited by pertussis toxin. ${ }^{52}$ Additional evidence for a role for $G_{i}$ in LPA signaling has been provided by Carr et al. ${ }^{5 \hat{3}}$

If LPA acts through a $G$ protein-coupled receptor, one would anticipate sensitivity of the responses to GTP analogs. Such has indeed been shown. GTP $\gamma$ S potentiates LPA-induced $\mathrm{IP}_{3}$ generation and GDP $\beta S$ inhibits it. ${ }^{19,54}$ Thus, LPA signaling is likely to involve one or more $G$ protein-coupled pathways.

Van der Bend et al. ${ }^{55}$ reported studies using a radiolabeled, photoactivated LPA analog $\left({ }^{32} \mathrm{P}\right]$-diazirine-LPA). The compound was found to act as an agonist, and, when applied to N1E115 cells, labeled a single, $38 \mathrm{kD}$ band in the plasma membrane. The band was digested completely by trypsin, and in addition was inhibited competitively by unlabeled LPA, but not by other phospholipids. The labeled protein did not appear to contain a significant amount of $\mathrm{N}$ linked oligosaccharides. When tested in tissues, significant labeling was observed in membranes from brain homogenates, but labeling was undetectable in liver and faint in lung.

Taken together, these data provide reasonably convincing evidence that LPA signals through one or more $G$ protein-coupled receptors. In fact, several recent papers have reported cloning of LPA receptors. Thus far, however, none of these has passed the test of conveying LPA responsivity on a non-LPA responsive cell type. An et al. ${ }^{56}$ cloned a cDNA homologous to that encoding sheep Edg2 from human lung. It encodes a 364 amino acid protein, most abundant in brain, with a hydrophilicity profile compatible with a $G$ protein coupled receptor. Edg2transfected fibroblasts showed enhanced responses to LPA, and overexpression in CHO cells correlated with enhanced LPA binding. The mouse Edg2 counterpart was similarly published as an LPA receptor. ${ }^{57}$ Guo et al. reported cloning of a different cDNA from Xenopus oocytes. ${ }^{58}$ Antisense constructs injected into oocytes inhibited LPA responses in these cells. At the moment it is unclear which, if any, of these receptors is "the" LPA receptor.

What appears to be clear is that multiple receptors for LPA exist. Using L-palmitoylserine and $\mathrm{N}$-palmitoyl-tyrosine, two compounds that antagonize oocyte LPA responses, and a cyclic form of LPA, cLPA, Liliom et al. were able to differentiate high- and low-affinity receptors on Xenopus oocytes. 59,60

\section{Intracellular signaling pathways}

LPA activates multiple $G$ proteins intracellularly: as mentioned above, the mitogenic response to the compound is sensitive to pertussis toxin, whereas the $\mathrm{Ca}^{2+}$ response is not. Thus, coupling to at least two $G$ proteins appears likely, one linked to mitogenic effects and sensitive to pertussis toxin, presumably $\mathrm{G}_{i}$, and one coupled to $\mathrm{Ca}^{2+}$ release and insensitive to pertussis toxin, presumably $\mathrm{G}_{\mathrm{q}}$. This latter pathway is sensitive to phorbol ester. In addition, van Corven et al. have shown that LPA treatment of cells induces arachidonic acid release, which, based on con- 


\section{CHAPTER 3}

centration-response data, GTP $\gamma \mathrm{S}$ sensitivity and pertussis toxin and phorbol ester blockade, appears to be mediated by a third $G$ protein class. ${ }^{19}$

LPA inhibits agonist-induced cAMP accumulation in several models, including fibroblasts, ${ }^{19}$ glioma cells, ${ }^{61}$ and hamster adipocytes. ${ }^{62}$ This effect is due to $G$ protein-mediated inhibition of adenylate cyclase. ${ }^{52}$ In fibroblasts, half-maximal inhibition is obtained at an LPA concentration of approximately $0.1 \mu \mathrm{M}$. Experiments with GTP analogs and pertussis toxin have demonstrated that this effect is mediated through a $G$ protein, and Wong et al. have shown that the inhibitory effects of LPA on CAMP accumulation are mimicked completely by a constitutively active mutant of $\mathrm{G}_{\mathrm{i} 2}{ }^{63}$

In addition to inhibiting cAMP generation in response to agonist, LPA sensitizes cells to agonist, so that agonist stimulation results in levels of cAMP higher than those found in the absence of LPA. This effect was observed first with serum, ${ }^{29}$ and later the serum effect was shown to be due to LPA. ${ }^{30}$ LPA-induced sensitization is mediated by $G_{i}$ and protein kinase $C$, as shown by block of the effect with pertussis toxin and phorbol ester.

LPA activates members of the ras family of small cytoplasmic $G$ proteins. This was initially suggested in a study by $\mathrm{Yu}$ et al, ${ }^{64}$ where it was shown that neutralizing antibody against cras was able to reverse phosphatidic acid-induced cell proliferation. Van Corven et al. ${ }^{65}$ studied ras activation by LPA in more detail. LPA, as well as thrombin and epidermal growth factor, induced a rapid accumulation of GTP on $\mathrm{p} 21^{\text {ras }}$ in Rat- 1 cells. The $E C_{50}$ for LPA was approximately 20 to $30 \mathrm{nM}$. Pretreatment with pertussis toxin largely abolished LPA-induced p $21^{\text {ras }}$ activation, but cholera toxin was without effect. The cell-permeant cAMP analog 8-Br-cAMP was also without effect, suggesting that $\mathrm{p} 21^{\mathrm{ras}}$ activation by LPA is independent of a $\mathrm{G}_{\mathrm{i}}$ mediated decrease in cAMP. In contrast, tyrosine-specific phosphorylation does appear involved, as LPA strongly induces tyrosine phosphorylation in fibroblasts and the protein kinase inhibitor genistein inhibits both LPA-induced phosphorylation and $\mathrm{p} 21^{\mathrm{ras}}$ activation.

LPA also activates rho, another member of the ras family, and it is this effect that is responsible for LPA's profound effects on the cytoskeleton. The exoenzyme C3 transferase inactivates rho proteins by ADP-ribosylation, and also inhibits the effects of LPA on the cytoskeleton. ${ }^{41}$ Rho activity also appears to play a role in the stimulation by LPA of tumor cell invasion, as LPA-induced invasiveness of MMl tumor cells could be inhibited by $\mathrm{C} 3$ treatment. $^{46} \mathrm{~A}$ Rho GDP/GTP exchange factor, RhoGEF, may link LPA receptor activation with Rho activity, inducing neurite retraction and cell rounding. ${ }^{66}$

As indicated, LPA induces protein phosphorylation. At least two of the kinases involved are known: MAP kinase and $\mathrm{p} 125^{\mathrm{FAK}}$. Kumagai et al. reported that LPA induced phosphorylation of $\mathrm{p} 125^{\mathrm{FAK}}$, 67 which may play a role in the LPA-mediated actions on focal adhesions and the cytoskeleton. In addition, the investigators demonstrated LPA-induced phosphorylation of MAP kinase, which is likely to be the link to the mitogenic actions of LPA. Similar findings were reported by Hordijk et al, ${ }^{68}$ and the effects on $\mathrm{pl} 25^{\mathrm{FAK}}$ were confirmed by Seufferlein and Rozengurt. ${ }^{69}$ The action of LPA in these studies was rapid: maximal effects were generally observed after 2 to 5 minutes. Pertussis toxin is without effect on $\mathrm{p} 125^{\mathrm{FAK}}$ phosphorylation, but, in contrast, MAP kinase activation is inhibited completely. Staurosporine, an inhibitor of several serine/threonine and tyrosine-specific protein kinases also inhibits MAP kinase phosphorylation as well as $\mathrm{p} 21^{\text {ras }}$ activation induced by LPA. These findings have been confirmed in a subsequent study. ${ }^{70}$ 
In contrast to its effect on $\mathrm{p} 21^{\text {ras }}, 8-\mathrm{Br}$-cAMP blocks LPA-induced MAP kinase activation. ${ }^{71}$ The mechanism of this effect appears to be rapid dephosphorylation of constitutively active MAP kinase.

The links between the LPA receptor(s) and MAP kinase are not yet clearly established. $G_{i}$ activation by LPA induces tyrosine kinase activity and recruitment of Grb2, which causes GDPGTP exchange on ras. Recently, a tyrosine-phosphorylated protein (p100) was reported that binds to $\mathrm{Grb} 2$ in a $\mathrm{G}_{\mathrm{i}}$ dependent manner. ${ }^{72}$ The p100-Grb2 complex may thus form the link between the $G$ protein and MAP kinase.

\section{ROLE FOR LPA}

Despite the insights gained in recent years into the cellular effects of LPA and the molecular mechanisms underlying these actions, it is still unclear what the physiologic or pathophysiologic role of the compound is. Most of the research has been performed at the cellular or tissue level; very few studies have investigated effects in organs or animals. However, some patterns have emerged that indicate potential roles for the compound.

At present, the main source of LPA in the body appears to be activated platelets, which would suggest a site of action in the vasculature. In addition, injured fibroblasts have been shown to release LPA. ${ }^{73}$ As LPA constricts vascular smooth muscle, activates platelets, and induces fibroblast and vascular smooth muscle ${ }^{74}$ proliferation, this suggests a potential role in the response to vascular injury. It is of interest that blood cells that are not involved in repair are some of the very few cells known to be unresponsive to the compound. As a lipid, LPA would be unlikely to migrate far in the hydrophilic environment of the vasculature, which would prevent undesired actions far removed from the injury site. In addition to a repair function in the vasculature, LPA could play a beneficial role in wound healing. We have shown LPA levels in acute wounds to be increased (Durieux ME: unpublished observations), and the possibility of enhancing wound healing by external LPA application is currently under investigation.

If LPA indeed plays a role in the maintenance of vascular integrity, the possibility exists that it also plays a role in one or more pathophysiologic states. One possibility would be an etiologic role in the development of cerebral vasospasm seen after subarachnoid hemorrhage, when it could be released in large amounts after clotting of subarachnoid blood. In fact, LPA levels have been shown to increase after experimental subarachnoid hemorrhage in piglets, ${ }^{14}$ and we have shown LPA levels to be increased after subarachnoid hemorrhage in humans, as well as in an experimental rabbit model. ${ }^{75}$ In addition, LPA, in the concentrations present after subarachnoid hemorrhage, constricts cerebral blood vessels: the effect on pial arterioles is modest, ${ }^{14}$ but basilar artery is constricted approximately $50 \%$, both in vitro and in vivo, by $1 \mu \mathrm{M}$ LPA (Durieux, unpublished observations). Interestingly, LPA has several other detrimental effects on brain. It increases permeability of tight junctions in cultured brain endothelial cells, ${ }^{76}$ and it decreases glutamate and glucose uptake by astrocytes. ${ }^{77}$

Thus, despite the fact that a clear role for LPA in physiology or pathophysiology remains to be established, an investigation of anesthetic effects on LPA signaling seems warranted. In addition to providing information on the interactions between anesthetics and a novel signaling molecule with a variety of remarkable actions, it will serve as a paradigm for the investigation of anesthetic interactions with $G$ protein coupled receptors in general, and in particular those for lipophilic ligands. 


\section{REFERENCES}

1. Durieux ME: Lysophosphatidate Signaling: Cellular Effects and Molecular Mechanisms. New York, Springer-Verlag/R.G. Landes Company, 1995

2. Bosch H: Phosphoglyceride metabolism. Annu Rev Biochem 1974; 43: 243-277

3. Lynch KL, Hopper DW, Carlisle SJ, Catalano JG, Zhang M, MacDonald IL: Structure/activity relationships in lysophosphatidic acid: the 2-hydroxy moiety. Molec Pharmacol 1997; 52: 75-81

4. Jalink K, van Corven EJ, Moolenaar WH: Lysophosphatidic acid, but not phosphatidic acid, is a potent $\mathrm{Ca}^{2+}$-mobilizing stimulus for fibroblasts. J Biol Chem 1990; 265: 12232-12239

5. Smyth SS, Hillery CA, Parise LV: Fibrinogen binding to purified platelet glycoprotein IIbIIIa (integrin $\alpha_{\mathrm{Ib}} \beta_{3}$ ) is modulated by lipids. J Biol Chem 1992; 267: 15568-15577

6. Jalink K, Moolenaar WH, van Duijn B: Lysophosphatidic acid is a chemoattractant for Dictyostelium discoideum amoebae. Proc Natl Acad Sci USA 1993; 90: 1857-1861

7. Tokumura A, Fukuzawa K: Effects of synthetic and natural lysophosphatidic acids on the arterial blood pressure of different animal species. Lipids 1978; 13: 572-574

8. Tokumura A, Fukuzawa K, Yamada S: Stimulatory effect of lysophosphatidic acids on uterine smooth muscles of non-pregnant rats. Arch Int Pharmcodyn Ther 1980; 245: 74-83

9. Sugiura T, Tokumura A, Gregory L, Nouchi T, Weintraub ST, Hanahan DJ: Biochemical characterization of the interaction of lipid phosphoric acids with human platelets: comparison with platelet-activating factor. Arch Biochem Biophys 1994; 311: 358-368

10. Tokumura A, Fukuzawa K, Akamatsu Y, Yamada S, Suzuki T: Identification of vasopressor phospholipid in crude soybean lecithin. Lipids 1978; 13: 468-472

11. Schumacher KA, Classen HG, Späth M: Platelet aggregation evoked in vitro and in vivo by phosphatidic acids and lysoderivatives: identity with substances in aged serum (DAS). Thromb Haemost 1979; 42: 631-640

12. Tokumura A, Fukuzawa K: Contractile actions of lysophosphatidic acids with a chemicallydefined fatty acyl group on longitudinal muscle from guinea-pig ileum. J Pharm Pharmacol 1981; 34: 514-516

13. Tokumura A, Yabe N, Fujimoto $\mathrm{H}$ : Lysophosphatidic acids induce contraction of rat isolated colon by two different mechanisms. J Pharm Pharmacol 1991; 43: 774-778

14. Tigyi G, Hong L, Yakubu M, Parfenova H, Shibata M, Leffler CW: Lysophosphatidic acid alters cerebrovascular reacitvity in piglets. Am J Physiol 1995; H2048-H2055

15. Moolenaar WH, Kruijer W, Tilly BC, Verlaan I, Bierman AJ, de Laat SW: Growth factorlike action of phosphatidic acid. Nature 1986; 323: 171-173

16. Benton AM, Gerrard JM, Michiel T, Kindom SE: Are lysophosphatidic acids or phosphatidic acids involved in stimulus activation coupling in platelets? Blood 1982; 60: 642-649

17. Jalink K, van Corven EJ, Moolenaar WH: Lysophosphatidic acid, but not phosphatidic acid, is a potent $\mathrm{Ca}^{2+}$-mobilizing stimulus for fibroblasts. J Biol Chem 1990; 265: 12232-12239

18. van Corven EJ, van Rijswijk A, Jalink K, van der Bend RL, van Blitterswijk WJ, Moolenaar WH: Mitogenic action of lysophosphatidic acid and phosphatidic acid on fibroblasts; dependence on acyl-chain length and inhibition by suramin. Biochem J 1992; 281: 163-169 


\section{LYSOPHOSPHATDDATE SIGNALING}

19. van Corven EJ, Groenink A, Jalink K, Eichholtz T, Moolenaar WH: Lysophosphatidateinduced cell proliferation: identification and dissection of signaling pathways mediated by $G$ proteins. Cell 1989; 59: 45-54

20. Gerrard JM, Kindom SE, Peterson DA, Peller J, Krantz KE, White JG: Lysophosphatidic acids; influence on platelet aggregation and intracellular calcium flux. Am J Path 1979; 96: 423-438

21. Simon MF, Chap H, Douste-Blazy L: Human platelet aggregation induced by 1-alkyllysophosphatidic acid and its analogs: a new group of phospholipid mediators? Biochem Biophys Res Comm 1982; 108: 1743-1750

22. Tokumura A, Yoshida J, Maruyama T, Fukuzawa K: Platelet aggregation induced by etherlinked phospholipids. 1. Inhibitory actions of bovine serum albumin and structural analogues of platelet activating factor. Thromb Res 1987; 46: 51-63

23. Watson SP, McConnell RT, Lapetina EG: Decanoyl lysophosphatidic acid induces platelet aggregation through an extracellular action; evidence against a second messenger role for lysophosphatidic acid. Biochem J 1985; 232: 61-66

24. Lapetina EG, Billah MM, Cuatrecasas P: The phosphatidylinositol cycle and the regulation of arachidonic acid production. Nature 1981; 292: 367-369

25. Gerrard JM, Robinson P: Identification of the molecular species of lysophosphatidic acid produced when platelets are stimulated by thrombin. Biochim Biophys Acta 1989; 1001: 282-285

26. Eichholtz T, Jalink K, Fahrenfort I, Moolenaar WH: The bioactive phospholipid lysophosphatidic acid is released from activated platelets. Biochem $J$ 1993; 291: 677-680

27. Tigyi G, Dyer DL, Matute C, Miledi R: A serum factor that activates the phosphotidylinositol phosphate signaling system in Xenopus oocytes. Proc Natl Acad Sci USA 1990; 87: 1521-1525

28. Tigyi G, Miledi R: Lysophosphatidates bound to serum albumin activate membrane currents in Xenopus oocytes and neurite retraction in PC12 pheochromocytoma cells. J Biol Chem 1992; 267: 21360-21367

29. Johnson RA, Ameson-Rotert LJ, Hoffman JM, Toews ML: Serum-induced sensitization of cyclic AMP accumulation in 1321N1 human astrocytoma cells. Molec Pharmacol 1991; 39: 399-406

30. Kreps DM, Whittle SM, Hoffman JM, Toews ML: Lysophosphatidic acid mimics seruminduced sensitization of cyclic AMP accumulation. FASEB J 1993; 7: 1376-1380

31. Dyer DL, Tigyi G, Miledi R: The effect of active serum albumin on PC12 cells: I. Neurite retraction and activation of the phosphoinositide second messenger system. Molec Brain Res 1992; 14: 293-301

32. Dyer DL, Tigyi G, Miledi R: The effect of active serum albumin on PC12 cells: II. Intracellular $\mathrm{Ca}^{2+}$ transients and their role in neurite retraction. Molec Brain Res 1992; 14: 302-309

33. Tigyi G, Dyer DL, Miledi R: Lysophosphatidic acid possesses dual action in cell proliferation. Proc Natl Acad Sci USA 1994; 91: 1908-1912

34. Tokumura A, Harada K, Fukuzawa K: Involvement of lysophospholipase D in the production of lysophosphatidic acid in rat plasma. Biochim Biophys Acta 1986; 875: 31-38

35. Jalink K, Eichholtz T, Postma FR, van Corven EJ, Moolenaar WH: Lysophosphatidic acid induces neuronal shape changes via a novel, receptor-mediated signaling pathway: similarity to thrombin action. Cell Growth Differ 1993; 4: 247-255 


\section{CHAPTER 3}

36. Koschel K, Tas PWL: Lysophosphatidic acid reverts the $\beta$-adrenergic agonist-induced morphological response in C6 rat glioma cells. Exp Cell Res 1993; 206: 162-166

37. Edwards JG, Campbell G, Carr M, Edwards CC: Shapes of cells spreading on fibronectin: measurement of the stellation of BHK21 cells induced by raising cyclic AMP, and of its reversal by serum and lysophosphatidic acid. J Cell Sci 1993; 104: 399-407

38. Manning TJ, Sontheimer H: Bovine serum albumin and lysophosphatidic acid stimulate calcium mobilization and reversal of cAMP-induced stellation in rat spinal cord astrocytes. Glia 1997; 20: 163-172

39. Rayan GM, Parizi M, Tomasek JJ: Pharmacologic regulation of Dupuytren's fibroblast contracture in vitro. J Hand Surg 1996; 21: 1065-1070

40. Jalink K, van Corven EJ, Hengeveld T, Morii N, Narumiya S, Moolenaar WH: Inhibition of LPA- and thrombin-induced neurite retraction and neuronal cell rounding by ADP ribosylation of the small GTP-binding protein Rho. Lysophosphatidate as an extracellular messenger; a study of early cellular effects and mechanism of action. Edited by Jalink K. Amsterdam, 1993, pp 45-59

41. Ridley AJ, Hall A: The small GTP-binding protein tho regulates the assembly of focal adhesions and actin stress fibers in response to growth factors. Cell 1992; 70: 389-399

42. Ha KS, Exton JH: Activation of actin polymerization by phosphatidic acid derived from phosphatidylcholine in IIC9 fibroblasts. J Cell Biol 1993; 123: 1789-1796

43. Smyth SS, Hillery CA, Parise LV: Fibrinogen binding to purified platelet glycoprotein IrbIIIa (integrin $\alpha \Pi b \beta 3$ ) is modulated by lipids. J Biol Chem 1992; 267: 15568-15577

44. Checovich WJ, Mosher DF: Lysophosphatidic acid enhances fibronectin binding to adherent cells. Arterioscler Thromb 1993; 13: 1662-1667

45. Barry ST, Flinn HM, Humphries MJ, Critchley DR, Ridley AJ: Requirement for Rho in integrin signaling. Cell Adh Comm 1997; 4: 387-398

46. Imamura F, Horai T, Mukai M, Shinkai K, Sawada M, Akedo H: Induction of in vitro tumor cell invasion of cellular monolayers by lysophosphatidic acid or phospholipase D. Biochem Biophys Res Commun 1993; 193: 497-503

47. Fernhout BJH, Dijcks FA, Moolenaar WH, Ruigt GSF: Lysophosphatidic acid induces inward currents in Xenopus laevis oocytes: evidence for an extracellular site of action. Eur J Pharmacol 1992; 213: 313-315

48. Durieux ME, Salafranca MN, Lynch KR, Moorman JR: Lysophosphatidic acid induces a pertussis toxin-sensitive $\mathrm{Ca}^{2+}$-activated $\mathrm{Cl}^{-}$current in Xenopus laevis oocytes. Am $\mathrm{J}$ Physiol 1992; 263: C896-C900

49. Ferguson JE, Hanley MR: Phosphatidic acid and lysophosphatidic acid stimulate receptorregulated membrane currents in the Xenopus laevis oocyte. Arch Biochem Biophys 1992; 297: 388-392

50. Shiono S, Kawamoto K, Yoshida N, Kondo T, Inagami T: Neurotransmitter release from lysophosphatidic acid stimulated PC12 cells: involvement of lysophosphatidic acid receptors. Biochem Biophys Res Comm 1993; 193: 667-673

51. Thomson FJ, Perkins I, Ahern D, Clark MA: Identification and characterization of a lysophosphatidic acid receptor. Molec Pharmacol 1994; 45: 718-723

52. Proll MA, Clark RB, Butcher RW: Phosphatidate and monooleylphosphatidate inhibition of fibroblast adenylate cyclase is mediated by the inhibitory coupling protein, $N_{i}$. Molec Pharmacol 1985; 28: 331-337 


\section{LYSOPHOSPHATIDATE SIGNALING}

53. Carr C, Grassie M, Milligan G: Stimulation of high-affinity GTPase activity and cholera toxin-catalysed $\left[{ }^{32} \mathrm{P}\right] \mathrm{ADP}$-ribosylation of $\mathrm{G}_{i}$ by lysophosphatidic acid (LPA) in wild-type and $\alpha 2 \mathrm{C} 10$ adrenoceptor-transfected Rat 1 fibroblasts. Biochem J 1994; 298: 493-497

54. Plevin R, MacNulty EE, Palmer S, Wakelam MJO: Differences in the regulation of endothelin-1- and lysophosphatidic acid-stimulated $\operatorname{Ins}(1,4,5) \mathrm{P}_{3}$ formation in Rat-1 fibroblasts. Biochem J 1991; 280: 609-615

55. van der Bend RL, Brunner J, Jalink K, van Corven EJ, Moolenaar WH, van Blitterswijk WJ: Identification of a putative membrane receptor for the bioactive phospholipid, lysophosphatidic acid. EMBO J 1992; 11:2495-2501

56. An S, Dickens MA, Bleu T, Hallmark OG, Goetzl EJ: Molecular cloning of the human Edg2 protein and its identification as a functional cellular receptor for lysophosphatidic acid. BBR 1997; 231: 619-622

57. Hecht JH, Weiner JA, Post SR, Chun J: Ventricular Zone Gene-1 (vzg-1) encodes a lysophosphatidic acid receptor expressed in neurogenic regions of the developing cerebral cortex. J Cell Biology 1996; 135: 1071-1083

58. Guo Z, Liliom K, Fischer DJ, Bathurst IC, Tomei LD, Kiefer MC, Tigyi G: Molecular cloning of a high-affinity receptor for the growth factor-like lipid mediator lysophospahtidic acid from Xenopus oocytes. Proc Natl Acad Sci USA 1996; 93: 14367-14372

59. Liliom K, Murakami-Murofushi K, Kobayashi S, Murofushi H, Tigyi G: Xenopus oocytes express multiple receptors for LPA-like lipid mediators. Am J Physiol 1996; 270: C772C777

60. Liliom K, Bittman R, Swords B, Tigyi G: $N$-palmitoyl-serine and $N$-palmitoyl-tyrosine phosphpric acids are selective competitive antagonists of the lysophosphatidic acid receptors. Molec Pharmacol 1996; 50: 616-623

61. Green DA, Clark RB: Comparison of the muscarinic-cholinergic and lysophosphatidate inhibition of fibroblasts adenylate cyclase demonstrating desensitization to the cholinergic stimulus. Life Sci 1981; 29: 1629-1639

62. Schimmel RJ, Honeyman TW, McMahon KK, Serio R, Clark RB: Inhibition of cyclic AMP accumulation in hamster adipocytes with phosphatidic acid: differences and similarities with $\alpha$-adrenergic effects. J Cyclic Nuc Res 1980; 6: 437-449

63. Wong YH, Federman A, Pace AM, Zachary I, Evans T, Pouysségur J, Bourne HR: Mutant $\alpha$ subunits of $G_{i 2}$ inhibit cyclic AMP accumulation. Nature 1991; 351: 63-65

64. Yu CL, Tsai MH, Stacey DW: Cellular ras activity and phospholipid metabolism. Cell 1988; 52: 63-71

65. van Corven EJ, Hordijk PL, Medema RH, Bos JL, Moolenaar WH: Pertussis toxin-sensitive activation of $\mathrm{p} 21^{\mathrm{ras}}$ by $\mathrm{G}$ protein-coupled receptor agonists in fibroblasts. Proc Natl Acad Sci USA 1993; 90: 1257-1261

66. Gebbink MF, Kranenburg O, Poland M, van Horck FP, Houssa B, Moolenaar WH: Identification of a novel, putative Rho-specific GDP/GTP exchange factor and a RhoA-binding protein: control of neuronal morphology. J Cell Biol 1997; 137: 1603-1613

67. Kumagai N, Morii N, Fujisawa K, Yoshimasa T, Nakao K, Narumiya S: Lysophosphatidic acid induces tyrosine phosphorylation and activation of MAP-kinase and focal adhesion kinase in cultured Swiss 3T3 cells. FEBS Lett 1993; 329: 273-276

68. Hordijk PL, Verlaan I, van Corven EJ, Moolenaar WH: Protein tyrosine phosphorylation induced by lysophosphatidic acid in Rat-1 fibroblasts; evidence that phosphorylation of MAP kinase is mediated by the $\mathrm{G}_{\mathrm{i}}-\mathrm{p} 21^{\text {ras }}$ pathway. J Biol Chem 1994; 269 : 645-651 


\section{CHAPTER 3}

69. Seufferlein T, Rozengurt E: Lysophosphatidic acid stimulates tyrosine phosphorylation of focal adhesion kinase, paxillin, and p130: signaling pathways and cross-talk with plateletderived growth factor. J Biol Chem 1994; 269: 9345-9351

70. Saville MK, Graham A, Malarkey K, Paterson A, Gould GW, Plevin R: Regulation of endothelin-1- and lysophosphatidic acid-stimulated tyrosine phosphorylation of focal adhesion kinase (pp125 fak ) in Rat-1 fibroblasts. Biochem J 1994; 301: 407-414

71. Hordijk PL, Verlaan I, Jalink K, van Corven EJ, Moolenaar WH: cAMP abrogates the p2 $1^{\text {ras }}$-mitogen-activated protein kinase pathway in fibroblasts. J Biol Chem 1994; 269: 3534-3538

72. Kranenburg O, Veriaan I, Hordijk PL, Moolenaar WH: Gi-mediated activation of the Ras/MAP kinase pathway involves a $100 \mathrm{kDa}$ tyrosine-phosphorylated $\mathrm{Grb} 2 \mathrm{SH} 3$ binding protein, but not Src or Shc. EMBO J 1998; 16: 3097-3105

73. Moolenaar WH: LPA: a novel lipid mediator with diverse biological actions. Trends Cell Biol 1994; 4: 213-219

74. Seewald S, Sachinidis A, Dusing R, Ko Y, Seul C, Epping P, Vetter H: Lysophosphatidic acid and intracellular signalling in vascular smooth muscle cells. Atherosclerosis 1997; 130: 121-131

75. Bavbek M, Kamiryo T, Durieux ME: The role of lysophosphatidic acid in radiation injury: a pilot study. Turk Neurosurg 1997; 7: 20-23

76. Schultze C, Smales C, Rubin LL, Staddon JM: Lysophosphatidic acid increases tight junction permeability in cultured brain endothelial cells. J Neurochem 1997; 68: 991-1000

77. Keller JN, Steiner MR, Mattson MP, Steiner SM: Lysophosphatidic acid decreases glutamate and glucose uptake by astrocytes. J Neurochem 1996; 67: 2300-2305 
RECEPTOR EXPRESSION IN OOCYTES

CHAPTER 4

\section{RECEPTOR EXPRESSION IN OOCYTES}

Marcel E. Durieux 


\section{CHAPTER 4}

\section{Receptor expression in oocytes}

The potential of the Xenopus laevis oocyte as an expression and cloning system was first realized in 1971. In that year Gordon et al. for the first time expressed foreign protein in the oocyte by injection of messenger RNA. ${ }^{1}$ During the intervening 25 years oocyte expression has developed into a highly versatile method for the study of recombinant proteins, and in particular for membrane signaling proteins such as G protein-coupled receptors (GCRs) and ion channels. Although the expression principles first laid down in Gordon's paper are to a large extent still valid, a variety of novel methodologies has been devised over the years, which have helped to make oocyte expression more flexible and powerful. Examples are the measurement of $\mathrm{Ca}^{2+}$-induced $\mathrm{Cl}^{-}$currents and of ${ }^{45} \mathrm{Ca}^{2+}$ efflux as convenient methods for the functional study of $\mathrm{Ca}^{2+}$ signaling receptors, and the development of cDNA injection into the germinal vesicle to bypass the need for mRNA preparation. More rarely used, but very elegant variations on the basic theme are the use of aequorin, both as a reporter of intracellular $\mathrm{Ca}^{2+}$ release and a control of adequate mRNA expression, and the combined expression of GCRs and G protein-regulated ion channels functioning as reporter molecules.

During the past ten years, the oocyte system has been used primarily as a cloning system. However, the system is also a powerful tool for the functional study of receptors. Chimeric or otherwise mutated receptors can be expressed easily and their structure/function relationships studied. Similarly, the functional properties of potential agonists and antagonists can be tested easily, in order to supplement binding studies. These uses of the system are likely to increase over the years to come.

In this chapter I will give an overview of use of the Xenopus oocyte expression system as a functional assay for the study of receptor properties. This section is based on a book chapter by the author. ${ }^{2}$

\section{THE XENOPUS OOCYTE}

The African Clawed Toad, Xenopus laevis, is an aquatic species of toad found primarily in southern Africa (despite the fact that the animal biologically is a toad, it has historically been called a frog, and I will concede to this established terminology). The animal has long been used for laboratory purposes, as it is remarkably easy to maintain and quite resistant to disease. In the past, injecting female frogs with a urine sample and watching for release of eggs was a routine method of pregnancy testing. Being aquatic, the animals can be kept in tanks without the need for a dry surface. In addition, the presence of several compounds with antibiotic activity in Xenopus skin makes infection at the site of operation remarkably rare. They easily adapt to commercial food and have few special temperature, water and light requirements.

Female Xenopus frogs carry a large supply of oocytes. Although most of these are immature cells, removal of mature oocytes will cause some of the immature cells to develop into mature cells. Thus, oocytes can be retrieved multiple times from a single frog. Mature oocytes have to be separated from the - usually much more numerous - immature ones. Dumont distinguished 6 stages of oocyte maturation, ${ }^{3}$ of which only stage 5 and 6 are suitable for expression purposes. These are easily recognized by being the largest oocytes, showing a clear division in dark and light poles, and uniform coloration of each pole. Oocytes with a white spot in the dark half should be avoided; these are undergoing spontaneous maturation (so-called germinal vesicle breakdown). The isolated oocytes obtained can be maintained for more than a week. 
As obtained from the ovary, the oocytes are surrounded by a thin layer of follicle cells, recognizable only by the presence of blood vessels and a shiny appearance. The combination of oocyte and follicular layer is at times termed a follicle. For most purposes, the follicle cells need to be removed, as they impede access of agonists to the oocyte, and in addition - and in contrast to the oocyte proper - contain a large array of endogenous receptors and channels. As the follicle cells connect to the oocyte by gap junctions, activation of signaling systems in the follicle cells can result in transmission of electrical or chemical signals to the oocyte, ${ }^{4}$ which can confound experimental results. Hence, the oocytes need to be defolliculated. Two common methods are in use. There seems to be little difference between them in the (minimal) amount of damage to membrane proteins. In manual defolliculation, the follicular layer is removed from each oocyte individually, using microforceps and a dissection microscope. Although requiring a significant amount of skill and time, this method probably provides the best assurance that complete defolliculation has been achieved, as each oocyte is inspected individually. Alternatively, oocytes can be defolliculated by gentle shaking in collagenase for several hours.

After defolliculation, the oocyte plasma membrane is still covered with an additional layer, the (acellular) vitelline membrane. This layer gives significant strength to the oocyte. Its removal is not necessary for most receptor studies. However, oocyte patch clamping requires removal of at least parts of the vitelline membrane, which can be accomplished manually after shrinking the cell by immersion in hypertonic solution.

Defolliculated Dumont stage 5 or 6 Xenopus oocytes are approximately 1.2 to $1.5 \mathrm{~mm}$ in diameter, and consist of well defined dark brown and light brown hemispheres. The dark brown color is caused by melanin accumulation; albino oocytes are white all over. If the oocyte were to develop into an egg and be fertilized, the dark hemisphere, termed the animal pole, would develop into the rostral segment of the frog, whereas the light hemisphere, termed the vegetal pole, would develop into the caudal segment. The distinction between animal and vegetal pole is relevant for several reasons. First, the germinal vesicle (the technical term for the oocyte nucleus) is located in the center of the animal pole, and approximately one third the oocyte diameter in size. Although not visible, its fixed location allows microinjection of cDNA. Second, the distribution of receptors and channels (endogenous as well as recombinantly expressed) over the oocyte surface is not homogeneous. Although exceptions exist, expression is generaily considered to be better over the animal pole, ${ }^{5}$ and agonist application is therefore better performed over that segment of the oocyte membrane.

The internal volume of the oocyte, approximately 0.5 to $1 \mu \mathrm{l}$, consists largely of yolk. In fact, it is this remarkable yolk production that makes the oocyte such an effective protein factory. In order to produce these large amounts of protein, the cell duplicates part of its genome encoding the building blocks for ribosomes, and as a result it has a complement of protein synthesizing machinery far exceeding that of other cells. The other large component of the interior is, as stated, the germinal vesicle. It can be visualized easily by carefully pulling open the oocyte membrane: it will appear as a small clear sphere within the white yolk protein.

\section{Endogenous G protein-coupled receptors}

One of the major advantages of the Xenopus oocyte for use as an expression system for GCRs is its remarkable paucity of endogenous receptors. In fact, only a single receptor type is consistently present, that for the phospholipid agonist lysophosphatidate (see Chapter 5). ${ }^{6}$ Whether this receptor also mediates responses to sphingosine-1-phosphate, or whether a separate 


\section{CHAPTER 4}

sphingosine-1-phosphate receptor is present is still an unresolved question (see Chapter 6). ${ }^{7}$ In fact, as discussed in Chapter 3, multiple subtypes of LPA receptor appear to exist in the oocyte. The presence of the lysophosphatidate receptor can be used to test for functional oocyte signaling.

A number of studies report the presence of other receptors endogenously expressed in Xenopus oocytes. However, most times these receptors are located in the follicular cell layer, and their activation leads to oocyte responses only because of the gap junctions present between oocyte and follicle cells. If oocytes are meticulously defolliculated, such responses almost invariably disappear or become so small to be practically irrelevant. Examples of such receptors endogenously present in follicles are muscarinic ${ }^{8-10}$ and angiotensin ${ }^{4}, 10,11$ receptors. Oocytes from occasional frogs (so-called "variant donors") may exhibit consistently large responses to acetylcholine. ${ }^{12}$ Despite the fact that these have received considerable attention, they are rare, and the fact that many investigators have successfully studied recombinantly expressed angiotensin and muscarinic receptors in Xenopus oocytes indicates that such occasional intrinsic oocyte responses form no hindrance to the study of exogenous receptors. We have expressed both muscarinic and angiotensin receptors, and never observed endogenous responses in defolliculated oocytes ${ }^{13,14}$ In contrast, folliculated oocytes will show $\mathrm{Ca}^{2+}$ transients in response to angioten$\sin ^{4}$ acetylcholine, ${ }^{12,15}$ follicle-stimulating hormone, ${ }^{16}$ adenosine, ${ }^{16} \beta$-adrenergic agonists, ${ }^{16}$ and other compounds.

The oocyte shows responses to extracellularly applied trypsin that are indistinguishable from those observed after GCR activation (see Chapter 8). ${ }^{17}$ These have recently been shown to be mediated by $\mathrm{G}$ proteins. ${ }^{18}$ Whether or not a receptor for trypsin or a related enzyme (analogous, maybe, to the thrombin receptor?) is present in the oocyte membrane is still an open question; however, if material used to stimulate oocytes (e.g. cell extracts) contains trypsin, responses may be anticipated.

\section{Endogenous signaling systems}

Despite its paucity of endogenous receptors, the oocyte contains the appropriate machinery to link activation of exogenously expressed receptors to intracellular responses. For the purpose of GCR expression, the most important intracellular signaling cascade is $\mathrm{G}_{\mathrm{q}} / \mathrm{G}_{\mathrm{o}}-$ linked Ca $\mathrm{Ca}^{2+}$ release, which can be quantified conveniently through an induced $\mathrm{Cl}^{-}$current. Other $\mathrm{G}$ proteins are present, however, and able to link receptor activation to opening of recombinantly expressed channels. Finally, a number of other endogenous channels are present in the oocyte, and may be activated - whether intended or not - by manipulation of the oocyte system.

\section{$G_{d} / G_{q}$ activation: $\mathrm{Ca}^{2+}$ release and $\mathrm{Ca}^{2+}$-activated $\mathrm{Cl}$ current}

Activation of GCRs, expressed in the oocyte membrane, that couple to $G_{o}$ or $G_{q}$ proteins endogenously present leads to activation of the oocyte phospholipase C (PLC) and release of inositoltrisphosphate $\left(\mathrm{IP}_{3}\right)$ from phosphatidylinositolbisphosphate $\left(\mathrm{PIP}_{2}\right)$. The oocyte has been shown to contain only a single subtype of PLC linking GCR stimulation to $\mathrm{Ca}^{2+}$ release, namely PLC- $\beta .{ }^{19}$ The $\mathrm{IP}_{3}$ generated by PLC activation releases $\mathrm{Ca}^{2+}$ from intracellular stores. Intracellular $\mathrm{Ca}^{2+}$ signaling in the oocyte has received a significant amount of attention over the past years, as is has been shown to be a complicated and even beautiful process. When confocal microscopy is used to study albino oocytes loaded with $\mathrm{Ca}^{2+}$-sensitive dye, it can be shown that $\mathrm{Ca}^{2+}$ is not 


\section{RECEPTOR EXPRESSION IN OOCYTES}

released as a single gradient across the oocyte, but rather as complex spirals that emerge from several points, move through the oocyte volume, and annihilate on contact. ${ }^{20},{ }^{21}$ These $\mathrm{Ca}^{2+}$ waves arise because of an interplay between $\mathrm{IP}_{3}$-stimulated release and $\mathrm{Ca}^{2+}$-activated $\mathrm{Ca}^{2+}$ release, and are probably responsible for the fluctuations observed in the $\mathrm{Ca}^{2+}$-activated $\mathrm{Cr}^{-}$currents described next.

Whereas confocal microscopy provides detailed insight in the kinetics of $\mathrm{Ca}^{2+}$ release, for most purposes it is sufficient to have a quantifiable measure of total release. This can be conveniently obtained by measuring $\mathrm{Ca}^{2+}$-activated $\mathrm{Cl}^{-}$current $\left(\mathrm{I}_{\mathrm{Cl}(\mathrm{Ca})}\right)$. The oocyte contains endogenous $\mathrm{Cl}^{-}$-selective ion channels that are gated by the intracellular $\mathrm{Ca}^{2+}$ concentration and probably play a role in maintaining oocyte polarity and segregation of intracellular contents. Hence, if membrane potential and ionic gradients across the cell membrane are chosen appropriately, intracellular $\mathrm{Ca}^{2+}$ release will result in an inward $\mathrm{Cl}^{-}$current that is measured easily by twoelectrode voltage clamp. Either peak current (in $\mu \mathrm{A}$ ) or total charge movement (the integral of the current trace, in $\mu \mathrm{C}$ ) have been used as a measure of $\mathrm{Ca}^{2+}$ release. As charge transfer provides us the closest correlation when plotted against the logarithm of agonist concentration, we routinely use charge movement as a measure of intracellular $\mathrm{Ca}^{2+}$ release. A data acquisition program is available that automates the integration step (see Chapter 7). ${ }^{22}$

\section{Other G proteins: $c A M P$ and channel activation}

The ease with which intracellular $\mathrm{Ca}^{2+}$ release is studied in the oocyte has made the system a favorite for the investigation of $\mathrm{Ca}^{2+}$-linked GCRs, and it has been used much less often for the study of receptors activating other $G$ proteins. However, it is certainly possible to use the system to study such receptors.

Activation of expressed receptors coupling to $G_{s}$ or $G_{i}$ proteins leads to the expected changes in cAMP concentration. Thus, these $G$ proteins are present and able to couple appropriately to exogenously expressed receptors. Unfortunately, $\mathrm{G}_{i}$-linked receptors are still difficult to study, as raising cAMP levels sufficiently to observe decreases after receptor activation remains problematic. This appears to be due to relative insensitivity of the oocyte adenylyl cyclase to the stimulating agent forskolin. ${ }^{16}$ The oocyte $G_{i}$ is sensitive to pertussis toxin, although in general much higher incubation concentrations and times are used (e.g. 1-2 $\mu \mathrm{g} / \mathrm{ml}$ for $12 \mathrm{~h}$ ) than employed for cells with a smaller volume.

A more promising method of studying $G_{i}$-coupled receptors is by coexpression of a $G$ protein regulated ion channel, such as a $\mathrm{K}$ channel.

\section{Endogenous channels}

For the investigator interested in using the oocyte system for expression of GCRs, the $\mathrm{Ca}^{2+}$-activated $\mathrm{Cl}^{-}$channel described above is no doubt the most important endogenous ion channel present. However, a number of other channels are expressed, and researchers should be aware of these, as their unplanned activation might lead to confounding results.

The presence of voltage-activated $\mathrm{Ca}^{2+}$ channels is well established. ${ }^{23}$ They are activated by depolarization of the oocyte membrane from between -100 and $-60 \mathrm{mV}$ to more than $-30 \mathrm{mV}$, and have a decay constant of approximately $0.5 \mathrm{~s}$. Because $\mathrm{Ca}^{2+}$ is normally present in physiologic solutions bathing the oocyte, activation of these channels will lead to $\mathrm{Ca}^{2+}$ influx and subse- 


\section{CHAPTER 4}

quent activation of $\mathrm{I}_{\mathrm{Cl}(\mathrm{Ca})}$, which could confound experimental results. Therefore, the holding potential of the oocyte should be maintained constant during experiments with GCRs.

Other currents described to be present in the oocyte include a hyperpolarization-induced $\mathrm{Cl}^{-}$current, a depolarization-induced slow $\mathrm{K}^{+}$current, and a depolarization-induced slow $\mathrm{Na}^{+}$ current. None of these responses should interfere with the study of GCRs, as long as membrane potential is maintained constant during experimentation. For a more in depth discussion of these endogenous channels, the reader is referred to a thorough review article. ${ }^{24}$

\section{TECHNIQUES OF OOCYTE EXPRESSION}

This section will discuss the two main methods by with GCRs can be expressed in Xenopus oocytes: by microinjection of RNA into the cytoplasm, or by microinjection of DNA into the germinal vesicle.

Despite meticulous technique and consistency in method, variation in expression levels will still be occasionally observed. It is not certain where this variation derives from. Clearly, diseases or changes in the animals' environment (temperature, water quality, food) may play a role, but even if these are ruled out, some degree of variation may persist. A seasonal variation has been suggested, but in our experience there is no consistent distribution over the year. Despite the fact that often no specific problem can be found and corrected, suboptimal expression tends to be temporary. Often, simply waiting for a few weeks will resolve the problem. Alternatively, some new frogs can be acquired and used.

RNA injection

The original, and still the most commonly used, method of expressing receptors in Xenopus oocytes is by intracellular microinjection of RNA encoding the protein to be expressed. The RNA can either be extracted from tissue (mRNA), or be prepared in vitro from a DNA template (cRNA). RNA injection into oocytes is performed into the vegetal pole, in order not to injure the germinal vesicle.

cDNA injection

Although used less commonly, receptor expression by injection of cDNA into the oocyte germinal vesicle has the advantage that smaller amounts of nucleic acid are needed, and that the step of cRNA preparation can be skipped. There is, however, some additional complexity to the technique. The cDNA is injected as the uncut vector construct. In order to allow the oocyte RNA polymerase to transcribe the $\mathrm{CDNA}$, an appropriate promoter should be incorporated in the vector. Several specifically designed oocyte promoters have been developed, but the presence of a CMV promoter upstream of the cDNA to be expressed has been shown to be effective as well.

Although it was known that the germinal vesicle is localized in the animal pole, it was for some time considered necessary to centrifuge the oocytes at low speed, with the animal pole facing outward, in order for the germinal vesicle to move against the cell membrane, where it was visible as a whitish spot and could be injected easily. However, this manipulation is time consuming, as oocytes need to be aligned individually, and in addition it tends to damage the cells, decreasing their survival rate. It has become clear by now that the position of the germinal 
vesicle is sufficiently consistent that it can be injected blindly with a high success rate. Expression by germinal vesicle injection often requires more culture time than expression by cytoplasmic injection.

\section{THE STUDY OF GCRS IN OOCYTES}

Once a GCR of interest is expressed in the oocyte membrane, an assay system is needed to determine its presence and function. As the questions that can be addressed using this system (from cloning to the effect of mutations in the receptor to the study of changes in agonist structure) range wide, a number of techniques have been developed to study GCRs expressed in oocytes. In this section, some of these will be discussed, and their advantages and disadvantages will be compared. In the context of the present thesis, only techniques used to study $\mathrm{Ca}^{2+}$ signaling receptors $\left(\mathrm{I}_{\mathrm{Cl}(\mathrm{Ca})},{ }^{45} \mathrm{Ca}^{2+}\right.$, and aequorin assays) will be discussed. Descriptions of methods to study receptors signaling through other intracellular mediators (co-expression with channels, cAMP measurements) are available elsewhere. ${ }^{2}$ The technique for applying anesthetics to oocytes will be described in subsequent chapters.

\section{$\mathrm{Ca}^{2+}$-induced $\mathrm{Cl}^{-}$currents}

The most widely used oocyte assay for the study of GCRs is measurement of $\mathrm{I}_{\mathrm{Cl}(\mathrm{Ca})}$ in response to intracellularly released $\mathrm{Ca}^{2+}$. The technique is relatively straightforward, rapid, and provides consistent quantitative results. The main practical difficulties with the technique derive from the difference in response size and kinetics as compared with "standard" electrophysiologic data; therefore, many hardware and software systems have difficulty dealing with them. For example, the membrane capacitance of the oocyte is enormous when compared with that of other cells, and as a result, the capacitance transient occurring after a membrane potential step easily saturates standard voltage clamp amplifiers. Similarly, many electrophysiology software packages have difficulty dealing with currents that develop over many seconds or even minutes, rather than milliseconds to seconds. Thus, specific hardware and software has been developed for this task (see Chapter 7).

In general, only a single response should be elicited from each oocyte, as receptor desensitization may occur. However, if required by the experimental protocol (e.g. studies investigating reversibility of inhibition), multiple responses can be obtained from most expressed receptors by allowing the oocyte to rest 10-30 min between agonist applications. In our laboratory, we reuse, at times, oocytes after one or more days of rest.

A number of variations on routine $I_{C l(C a)}$ measurement can be used to study effects of compounds on intracellular signaling pathways. For example, localization of site of action of drugs known to interfere with GCR signaling can be easily accomplished using the oocyte. Microinjection of the compound into the cell can determine if its site of action is intracellular or extracellular. Determining the effect of the compound on $\mathrm{I}_{\mathrm{Cl}(\mathrm{Ca})}$ induced by microinjection of intracellular mediators such as $\mathrm{IP}_{3}$ or $\mathrm{Ca}^{2+}$ can determine its exact site of action within intracellular signaling pathways. 


\section{CHAPTER 4}

${ }^{45} \mathrm{Ca}^{2+}$ efflux

A different method to assess intracellular $\mathrm{Ca}^{2+}$ release indirectly is by the measurement of efflux of $\mathrm{Ca}^{2+}$ from the oocyte. The procedure is based on the presence in the oocyte membrane of endogenous voltage-gated $\mathrm{Ca}^{2+}$ channels. Cells are first loaded with ${ }^{45} \mathrm{Ca}^{2+}$. Agonist-induced

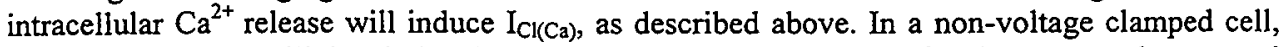
this inward current will depolarize the membrane, inducing opening of endogenous voltage-gated channels. ${ }^{45} \mathrm{Ca}^{2+}$ will flow through these channels and appear in the medium. This can then be assayed quantitatively by scintillation counting.

Although the method allows testing of multiple oocytes at the same time, it lacks some of the advantages of the electrophysiologic technique. The sensitivity and time resolution of the ${ }^{45} \mathrm{Ca}^{2+}$ assay is less than that obtained with direct $\mathrm{I}_{\mathrm{Cl}(\mathrm{Ca})}$ measurements, and the intracellular manipulations possible with the electrophysiology technique are not as easily performed. In addition, the method has the inherent disadvantage of requiring the use of a radioactive compound (however, ${ }^{45} \mathrm{Ca}^{2+}$ spills are cleaned easily with EGTA).

Aequorin

The use of aequorin is another approach to circumvent the necessity of individual oocyte testing. In addition, it provides a built-in control for adequacy of protein expression.

Aequorin is a protein obtained from jellyfish that emits light when it binds $\mathrm{Ca}^{2+}$. Its cDNA has been cloned, and either the protein $\left(50 \mathrm{nl}\right.$ of $\left.5 \mathrm{mg} / \mathrm{ml}^{25}\right)$ or its $\mathrm{mRNA}$ can be injected into oocytes for expression. ${ }^{26}$ Aequorin luminescence in response to intracellular $\mathrm{Ca}^{2+}$ release can be used as a reporter for receptor activation. Although the technique can be performed in regular oocytes, ${ }^{25}$ light emission may be measured more conveniently in albino oocytes. The advantage of injection of mRNA (or CDNA) encoding aequorin over injection of the protein itself is in the control it offers for adequate expression. In those oocytes that express a functional receptor, intracellular $\mathrm{Ca}^{2+}$ will be released in response to agonist, bind to aequorin, and result in light emission, which is detected by the luminometer. Alternatively, for more detailed study, a single oocyte can be observed under a microscope with attached video imaging system. If desired, electrophysiological measurements can be performed at the same time. ${ }^{25}$

To ascertain that the injected nucleic acid is adequately expressed and that the cellular signaling system is functional, the cells can be exposed to lysophosphatidate. Light emission in response to this agonist confirms that the oocyte signaling system is intact, and that at least the aequorin is adequately expressed.

\section{CONCLUDING REMARKS}

Within the past few years, creative strategies have been employed to enhance the value of Xenopus oocytes for expression cloning and functional characterizations of GCRs. In particular, the expression of ion channels that act as reporters of GCR-activated signaling pathways promises to be an important advance in the study of GCRs that do not activate the endogenous $\mathrm{Ca}^{2+}$ activated $\mathrm{Cl}^{-}$current. As nearly all of the GCRs that have been characterized by pharmacologic criteria have been identified by molecular cloning, the use of the oocyte as an expression cloning system is likely to decline. The increasing number of orphan GCRs combined with the decreas- 


\section{RECEPTOR EXPRESSION IN OOCYTES}

ing number of known endogenous ligands may prompt the development of strategies to screen orphan GCRs for responsiveness to various bioactive compounds. As novel uses and techniques continue to be developed, Xenopus oocytes are likely to remain an important tool in future studies of GCR structure and function.

\section{REFERENCES}

1. Gordon JB, Lane CD, Woodland HR, Marbaix G: Use of frog eggs and oocytes for the study of messenger RNA and its translation in living cells. Nature 1971;233: 177

2. Lee A, Durieux ME: The use of Xenopus oocytes for expression and cloning of G proteincoupled receptors. Identification and expression of $G$ protein-coupled receptors. Edited by Lynch KR. 1997

3. Dumont N: 1. Stages of oocyte development in laboratory maintained animals. J Morphol 1972; 136: 153-180

4. Sandberg K, Hong J, lida $\mathrm{T}$, Catt $\mathrm{KJ}$ : Intracellular communication between follicular angiotensin receptors and Xenopus laevis oocytes: mediation by an inositol 1,4,5-trisphosphatedependent mechanism. J Cell Biol 1992; 117: 157-167

5. Matus-Leibovitch N, Lupu-Meiri M, Oron Y: Two types of muscarinic responses in Xenopus oocytes. II. Hemispheric asymmetry of responses and receptor distribution. Pflugers Arch 1990; 417: 194-199

6. Durieux ME, Salafranca MN, Lynch KR, Moorman JR: Lysophosphatidic acid induces a pertussis toxin-sensitive $\mathrm{Ca}^{2+}$-activated $\mathrm{Cl}^{-}$current in Xenopus laevis oocytes. Am J Physiol 1992; 263: C896-C900

7. Durieux ME, Carlisle SJ, Salafranca MN, Lynch KR: Endogenous responses to sphingosine1-phosphate in $X$. laevis oocytes: similarities with lysophosphatidic acid signaling. Am J Physiol 1993; 264: C1360-C1364

8. Kusano K, Miledi R, Stinnakre J: Acetylcholine receptors in the oocyte membrane. Nature 1977; 270: 739-741

9. Dascal N, Landau EM: Types of muscarinic receptors in Xenopus oocytes. Life Sci 1980; 27: $1423-1428$

10. Lacy P, Murray-McIntosh RP, McIntosh JEA: Angiotensin II and acetylcholine differentially activate mobilization of inositol phosphates in Xenopus laevis ovarian follicles. Pflugers Arch 1992; 420: 127-135

11. Sakuta H, Sekiguchi M, Okamoto K, Sakai $Y$ : Endogenous angiotensin II receptors in Xenopus oocytes and eggs. Eur J Pharmacol 1991; 29: 31-39

12. Lupu-Meiri M, Shapira $\mathrm{H}$, Matus-Leibovitch N, Oron $\mathrm{Y}$ : Two types of intrinsic muscarinic responses in Xenopus oocytes. I. Differences in latencies and ${ }^{45} \mathrm{Ca}$ efflux kinetics. Pflugers Arch 1990; 417: 391-397

13. Durieux ME: Halothane inhibits signaling through $\mathrm{ml}$ muscarinic receptors expressed in Xenopus oocytes. Anesthesiology 1995; 82: 174-182

14. Durieux ME: Inhibition by ketamine of muscarinic acetylcholine receptor function. Anesth Analg 1995; 81: 57-62

15. Ji H, Sandberg K, Catt KJ: Differential activation of inositol 1,4,5-trisphosphate-sensitive calcium pools by muscarinic receptors in Xenopus oocytes. Cell Calcium 1993; 14: 649-662 


\section{CHAPTER 4}

16. Greenfield LJ, Hackett JT, Linden J: Xenopus oocyte $\mathrm{K}^{+}$current. II. Adenylyl cyclase-linked receptors on follicle cells. Am J Physiol (Cell Physiol) 1990; 259: C784-C791

17. Durieux ME, Salafranca MN, Lynch $\mathrm{KR}$ : Trypsin induces $\mathrm{Ca}^{2+}$-activated $\mathrm{Cl}^{-}$currents in $X$. laevis oocytes. FEBS Lett 1994; 337: 235-238

18. Shapira H, Amit I, Revach M, Oron Y, Battey JF: $G \alpha_{14}$ and $G \alpha_{q}$ mediate the response to trypsin in Xenopus oocytes. J Biol Chem 1997; 273: 19431-19436

19. Ma H-W, Blitzer RD, Healy EC, Premont RT, Landau EM, Iyengar R: Receptor-evoked $\mathrm{Cl}^{-}$ current in Xenopus oocytes is mediated through a $\beta$-type phospholipase $\mathrm{C}$; cloning a new form of the enzyme. J Biol Chem 1993; 268: 19915-19918

20. Lechleiter J, Girard S, Clapham D, Peralta E: Subcellular patterns of calcium release determined by $G$ protein-specific residues of muscarinic receptors. Nature 1991; 350: 505-508

21. Lechleiter JD, Clapham DE: Molecular mechanisms of intracellular calcium excitability in $X$ laevis oocytes. Cell 1992; 69: 283-293

22. Durieux ME: OoClamp: An IBM-compatible software system for the study of receptors expressed in Xenopus oocytes. Comput Meth Progr Biomed 1993; 41: 101-105

23. Dascal N, Snutch TP, Lubbert H, Davidson NR, Lester HA: Expression and modulation of voltage-dependent calcium currents after RNA injection in Xenopus oocytes. Science 1986; 231: 1147

24. Dascal N: The use of Xenopus oocytes for the study of ion channels. CRC Crit Rev Biochem 1987; 22: 317-387

25. Parker I, Miledi R: Changes in intracellular calcium and in membrane currents evoked by injection of inositol trisphosphate into Xenopus oocytes. Proc R Soc Lond 1986; 228: 307 315

26. Sandberg K, Marwick AJ, Trinh DP, Katt KJ: Calcium mobilization by angiotensin II and neurotransmitter receptors expressed in Xenopus laevis oocytes. FEBS Lett 1988; 241 : 177 180,1988 


\title{
CHAPTER 5
}

Lysophosphatidic acid induces a pertussis toxin-sensitive

$\mathrm{Ca}^{2+}$-activated $\mathrm{Cl}^{-}$current in Xenopus laevis oocytes

\author{
Marcel E. Durieux \\ Mina N. Salafranca \\ Kevin R. Lynch \\ J. Randall Moorman
}

Am J Physiol 1992; 263 (Cell Physiol 32): C896-C900

Reproduced with permission from the publisher. 


\title{
Lysophosphatidic acid induces a pertussis toxin-sensitive $\mathrm{Ca}^{2+}$-activated $\mathrm{Cl}^{-}$ current in Xenopus laevis oocytes
}

\begin{abstract}
Lysophosphatidic acid (LPA) induces a $\mathrm{Ca}^{2+}$-activated $\mathrm{Cl}^{-}$current in defolliculated Xenopus laevis oocytes. The response appears mediated by a specific membrane receptor, because no current is induced when related compounds [phosphatidic acid (PA), lysophosphatidylcholine (LPC), and lysophosphatidylserine (LPS)] are applied extracellularly or when LPA is injected intracellularly. Incubation in pertussis toxin prevents the response. The response is mediated by a $\mathrm{Ca}^{2+}$-activated $\mathrm{Cl}^{-}$current because 1) it is abolished by intracellular ethylene glycol-bis( $\beta$-aminoethyl ether)-N,N,N',N'-tetraacetic acid (EGTA; $5 \mathrm{mM}$ ) but not affected by changes in extracellular $\mathrm{Ca}^{2+}$ concentration and 2) the reversal potential becomes more positive at lower $\mathrm{Cl}^{-}$concentrations. Suramin $(2 \mathrm{mM})$ blocks the LPA-induced current, but PA, LPS, LPC, and the platelet-activating factor antagonist WEB-2086 do not. The response is dose dependent for LPA concentrations from $10^{-8}$ to $10^{-3} \mathrm{M}$. Incubation of oocytes in LPA does not induce germinal vesicle breakdown. These findings suggest that this novel oocyte response to LPA is mediated by a specific membrane receptor linked to a pertussis toxin-sensitive $G$ protein.
\end{abstract} factor

Key words: G protein-coupled receptors; chloride channels; suramin; platelet-activating

\section{INTRODUCTION}

The polar lipid L- $\alpha$-lysophosphatidic acid (monoacylglycerol $\Delta 3$-phosphate; LPA) has attracted attention as a potential intercellular messenger because it causes species-specific blood pressure changes when injected intravenously, ${ }^{14}$ aggregates platelets, ${ }^{12}$ and contracts uterine ${ }^{15}$ and colonic ${ }^{16}$ smooth muscle. LPA is also a mitogen in Rat-1 cells and human foreskin fibroblasts.' These two cell types respond to LPA application with phosphoinositide hydrolysis and a transient elevation of intracellular $\mathrm{Ca}^{2+}$ as measured by $\left[{ }^{3} \mathrm{H}\right]$ inositol phosphate accumulation and Indo-1 fluorescence.' In these cell lines, this effect was not prevented by pertussis toxin (PT) pretreatment. In the present study, we report that defolliculated Xenopus laevis oocytes respond to LPA with a Ca ${ }^{2+}$-activated $\mathrm{Cl}^{-}$current and that, in contrast to the findings in mammalian cells, this response is blocked by incubation in PT. The presence of this response offers a new experimental system for study of the putative LPA receptor and should be considered when expressing membrane receptors in the $X$. laevis oocyte.

\section{MATERIALS AND METHODS}

\section{Materials}

LPA (1-oleoyl-2-hydroxy-sn-glycero-3-phosphate) and phosphatidic acid (PA; 1,2-dipalmitoyl-sn-glycero-3-phosphate) were obtained from Avanti Polar Lipids (Alabaster, AL) and were dissolved in a $1 \%$ solution of bovine serum albumin (BSA; ICN Biomedicals, 


\section{LYSOPHOSPHATIDATE CURRENTS IN OOCYTES}

Cleveland, $\mathrm{OH}$ ). PT was a kind gift of Dr. E. Hewlett at the University of Virginia. The platelet-activating factor (PAF) antagonist WEB-2086 was kindly provided by Dr. T. Y. Shen at the University of Virginia. Molecular biology reagents were obtained from Promega (Madison, WD). All other chemicals were obtained from Sigma Chemical (St. Louis, MO).

\section{Oocyte harvesting, incubation, and injection}

Female $X$ laevis were obtained from Xenopus I (Ann Arbor, MI), housed in an established frog colony, and fed regular frog brittle twice weekly. For removal of oocytes, a frog was anesthetized by immersion in ice until unresponsive. A $1-\mathrm{cm}$ incision was made in a lower abdominal quadrant, and a lobule of ovarian tissue, containing 200-300 oocytes, was removed and placed in modified Barth's solution [MBS; in mM: $88 \mathrm{NaCl}, 1 \mathrm{KCl}, 2.4 \mathrm{NaHCO}_{3}, 0.41 \mathrm{CaCl}_{2}$, $0.82 \mathrm{MgSO}_{4}, 0.3 \mathrm{CaNO}_{3}, 0.1$ gentamicin, and $15 \mathrm{~N}^{\prime}$-2-hydroxyethylpiperazine-N'-2-ethanesulfonic acid (HEPES), $\mathrm{pH}$ 7.6]. The wound was closed in two layers, the animal was allowed to recover from anesthesia, kept in a separate tank overnight, and returned to the colony the following day. The ovarian tissue was washed immediately and copiously in MBS and dissected into small clusters of 20-50 oocytes. Dumont stage V and VI oocytes were isolated manually and cultured in MBS at $18-19^{\circ} \mathrm{C}$. Before each experiment, oocytes were defolliculated manually. For injection of mRNA, folliculated oocytes in MBS were placed on ice and injected with $50 \mathrm{nl}$ of mRNA in $100 \mathrm{mM} \mathrm{KCl}$, using a manual microinjector (Microdispenser; Drummond Scientific, Broomall, PA). The cells were cultured for 3 days and defolliculated manually before the experiment.

\section{Electrophysiological recording}

A single defolliculated oocyte was placed in a recording chamber ( $3 \mathrm{ml}$ vol), perfused at 3-4 $\mathrm{ml} / \mathrm{min}$ with a solution containing (in $\mathrm{mM}$ ) $150 \mathrm{NaCl}, 5 \mathrm{KCl}, 1 \mathrm{MgCl}_{2}, 2 \mathrm{CaCl}_{2}, 10$ dextrose, and 10 HEPES ( $\mathrm{pH}$ 7.4). Microelectrodes were pulled in one stage from capillary glass (type 6010; AM-1 Systems, Everett, CA) on a Flaming/Brown micropipette puller (model P-86; Sutter Instrument, Novato, CA) and beveled to sharpness on an electrode grinder (Narishige KG-6, Tokyo, Japan). They were filled with $3 \mathrm{M} \mathrm{KCl}$, and tip resistances were usually 1-3 M $\Omega$. The cell was voltage clamped using a conventional two-microelectrode voltage clamp amplifier (Oocyte Clamp OC725; Warner, New Haven, CT) connected to commercially available data acquisition and analysis software (Axon Instruments, Foster City, CA) and an IBM-compatible personal computer. Membrane current was sampled at $16.7 \mathrm{~Hz}$ and recorded for $\sim 10 \mathrm{~s}$ before and $50 \mathrm{~s}$ after application of the test compounds. Before drug application the bath perfusion was stopped, and compounds were delivered in 30- $\mu 1$ aliquots over 1-2 s using a handheld micropipette positioned $\sim 5 \mathrm{~mm}$ from the oocyte. Responses were quantified by integrating the current trace by quadrature and are reported as microcoulombs (mean $\pm \mathrm{SE}$ ). All experiments were performed at room temperature.

To determine the reversal potentials of the induced current, responses to $10 \mu \mathrm{M}$ LPA were determined at several holding potentials. This was repeated at several extracellular $\mathrm{Cl}^{-}$ concentrations. Low $\mathrm{Cl}^{-}$solutions were prepared by reducing the amount of $\mathrm{NaCl}$ and replacing it with an isosmolar amount of $\mathrm{N}$-methyl-D-glucamine and by adjusting the $\mathrm{pH}$ with methane-

sulfonic acid. Each oocyte was tested at one potential in one bath solution. Reversal potentials were estimated from the $x$-intercept of a plot of charge movement vs. holding potential. 


\section{CHAPTER 5}

\section{Intracellular injections}

For the intracellular injections of LPA and ethylene glycol-bis( $\beta$-aminoethyl ether)-N,N,N',N'-tetraacetic acid (EGTA), a third micropipette was used, connected to an automated nitrogen-driven microinjector (Picospritzer, General Valve, Fairfield, NJ). The micropipette was calibrated volumetrically by counting the number of injections needed to expel a known volume of solution. It was then introduced in the cell, and a 50-nl volume was administered. The adequacy of injection was verified by observing the slight increase in cell size on injection.

\section{$R N A$ transcription}

The rat M1 muscarinic acetylcholine receptor cDNA clone, a 2.8-kilobase pair Xho I fragment in the pGEM1 vector (Promega, Madison, WD), was a gift of Dr. T. I. Bonner (National Institute of Mental Health, Bethesda, MD). It was linearized with Hind III, transcribed in vitro in the presence of a capping analogue $\left({ }^{7 \mathrm{~m}} \mathrm{GpppG}\right)$, and the resulting mRNA was diluted in $100 \mathrm{mM}$ $\mathrm{KCl}$ to a concentration of $1 \mathrm{mg} / \mathrm{ml}$.

\section{RESULTS}

\section{$L P A$ induces a current in $\mathrm{X}$. laevis oocytes}

Application of LPA $\left(10^{-7}\right.$ to $\left.10^{-3} \mathrm{M}\right)$ to oocytes at a holding potential of $-70 \mathrm{mV}$ resulted in a transient inward current (Figure 1A). Typically, $1 \mu \mathrm{M}$ LPA induced a 2- to 6- $\mu \mathrm{C}$ response. Vehicle (BSA 1\%) alone did not induce this response. The current developed after a latency of $\geq 1 \mathrm{~s}$ and consisted of a fast inward component, followed by a relaxation over several seconds, on which small fluctuations were superimposed. The oocyte response to LPA desensitized only partially. If the recording chamber was adequately washed with LPA-free solution ( $150 \mathrm{ml}$ over 30 $\mathrm{min}$ ), multiple responses could be obtained from a single oocyte ( 3 oocytes, 1 frog; Figure 1B).

\section{Response to LPA is specific}

Because LPA is a lipophilic compound, the currents observed might have been caused by nonspecific interactions with the oocyte membrane. To differentiate nonspecific effects from specific interactions, we performed the following experiments.

Structurally related compounds do not induce the response. We tested the LPA analogues PA ( 8 oocytes, 3 frogs), lysophosphatidylcholine (78 oocytes, 6 frogs), and lysophosphatidylserine (LPS; 16 oocytes, 3 frogs) for activity and for their ability to block the LPA response. Except for PA, none of these compounds induced currents. PA $(1 \mu \mathrm{M})$ induced occasional small responses. As a group, responses to PA $(0.3 \pm 0.2 \mu \mathrm{C})$ were not significantly different from responses to application of vehicle. None of these compounds blocked the oocyte response to LPA (data not shown).

LPA is related structurally to PAF, which mediates its actions through a G protein-mediated pathway. The PAF receptor can be blocked by several structurally unrelated com- 


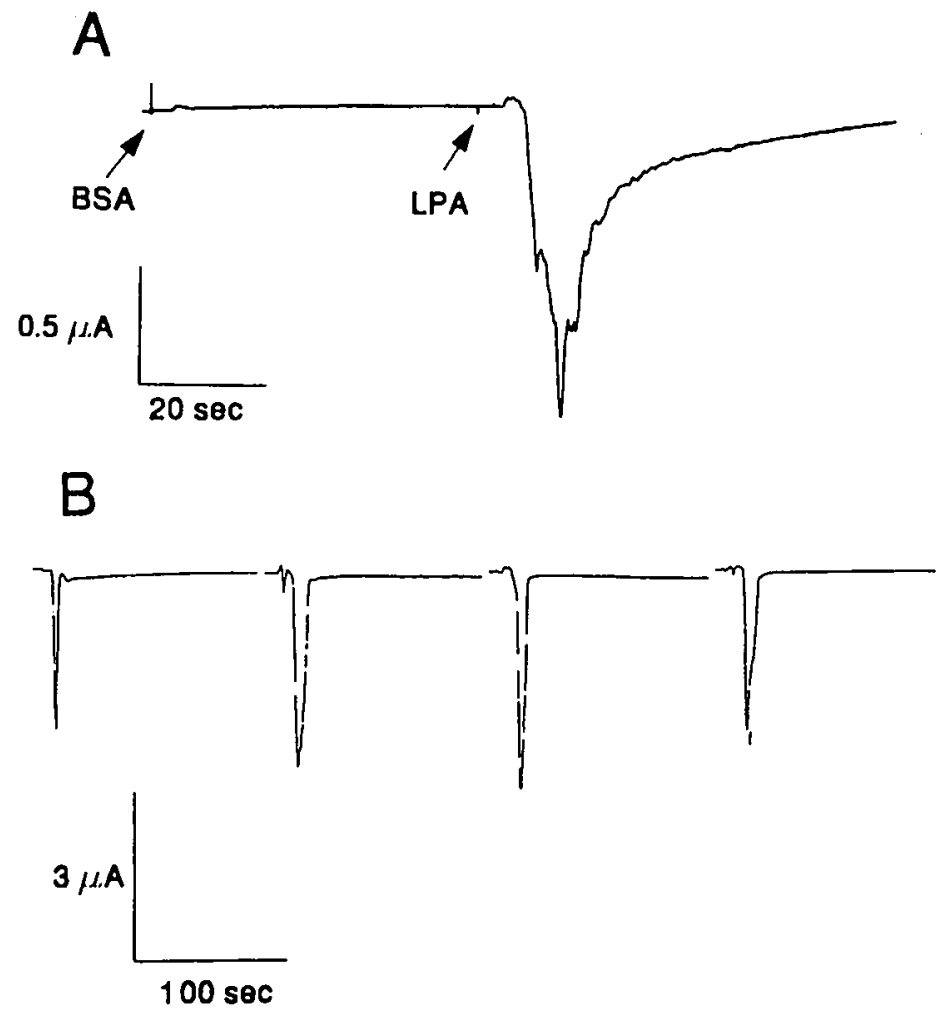

Figure 1. LPA-induced currents in Xenopus ocytes. A. Inward current induced by $100 \mu \mathrm{M}$ lysophosphatidic acid (LPA) in defolliculated $X$. laevis oocyte at holding potential of $-70 \mathrm{mV}$. Application of $1 \%$ bovine serum albumin (BSA) alone does not induce response. Peak current of LPA response, $1,100 \mathrm{nA}$; total charge movement, $6.3 \mu \mathrm{C}$. B: LPA-induced current does not significantly desensitize. LPA $(100 \mu \mathrm{M})$ was applied repeatedly to single oocyte at holding potential of $-70 \mathrm{mV}$ and washed with $\sim 150 \mathrm{ml}$ over 30 min between applications. Charge movements: $2.0,4.4,2.7$ and $2.8 \mu \mathrm{C}$. Holding currents at beginning of each recording: $-146,-181,-171$ and $-156 \mathrm{nA}$, respectively.

pounds. " We tested the PAF antagonist WEB-2086 (a synthetic benzodiazepine; 5 oocytes, 1 frog) for agonist and antagonist activity. It neither induced currents nor blocked the LPA-induced current in oocytes (data not shown).

The anthelmintic polyanionic drug suramin, which inhibits the mitogenic responses to LPA in fibroblasts, ${ }^{2}$ decreased the currents induced in oocytes by LPA. At a concentration of 2 $\mathrm{mM}$, the response to $10 \mu \mathrm{M}$ LPA was decreased from $4.6 \pm 0.4$ to $1.4 \pm 0.1 \mu \mathrm{C}$ (16 oocytes, 3 frogs), a decrease of $70 \%$. This decrease could not be reversed by washing the bath ( $150 \mathrm{ml}$ over $30 \mathrm{~min}$ ). Combinations of $100 \mu \mathrm{M}$ LPA-2mM suramin or $10 \mu \mathrm{M}$ LPA- $-5.5 \mathrm{mM}$ suramin also resulted in an irreversible decrease in the LPA-induced current (data not shown).

Intracellular injection of LPA does not induce a current. A volume of $50 \mathrm{nl}$ LPA $\left(10^{-5}\right.$ $M$ ) injected into the oocyte did not result in a current response, whereas LPA applied extracellu- 


\section{A}

Control

\section{PT incubated}
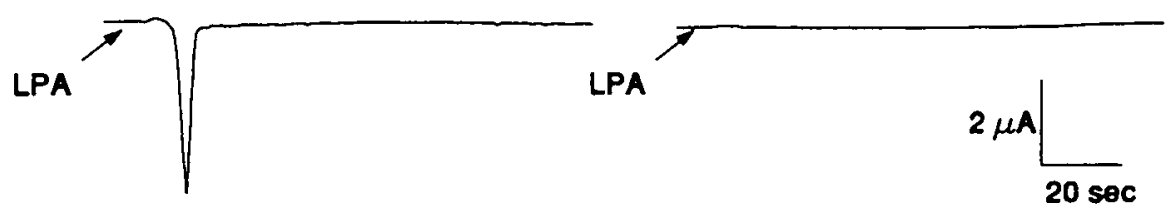

B

Control

PT incubated
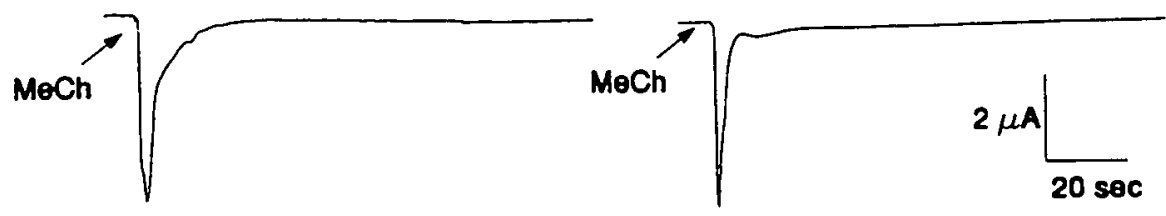

Figure 2. LPA response is PT sensitive. $A$ : LPA $(1 \mu \mathrm{M})$ applied to defolliculated oocyte incubated over night in $2 \mu \mathrm{g} / \mathrm{ml}$ pertussis toxin (PT; charge movement $0.3 \mu \mathrm{C}$ ) and to control oocyte from same frog incubated in modified Barth's solution (charge movement $5.7 \mu \mathrm{C}$ ). Holding potential, $-70 \mathrm{mV}$. LPA response is PT sensitive. $B$ : Methylcholine (MeCh: $3 \mu \mathrm{M}$ ) applied to defolliculated oocytes 3 days after injection with $50 \mathrm{ng} \mathrm{M}_{1}$ muscarinic acetylcholine receptor mRNA, one incubated overnight in $2 \mu \mathrm{g} / \mathrm{ml} \mathrm{PT}$ (charge movement $8.7 \mu \mathrm{C}$ ), and one control oocyte from same frog (charge movement $10.6 \mu \mathrm{C})$. Holding potential, $-70 \mathrm{mV}$. Methylcholine response is not PT sensitive.

larly to the same oocyte did produce the usual response (5 oocytes, 2 frogs; see Figure 3A). This finding suggests that LPA acts through an extracellular site of action and not through nonspecific membrane interactions.

\section{$L P A$ response is $P T$ sensitive}

Overnight incubation in $2 \mu \mathrm{g} / \mathrm{ml} \mathrm{PT}$, a dose shown to inhibit PT-sensitive G proteins in the $X$. laevis oocyte, ${ }^{8,9}$ decreased the oocyte response to $10^{-4} \mathrm{M}$ LPA from $8.8 \pm 1.6(\mathrm{n}=48)$ to $0.9 \pm 0.3(\mathrm{n}=52) \mu \mathrm{C}$, a decrease of $90 \%$ (Figure $2 \mathrm{~A})$. This finding was reproduced in oocytes from 9 of 10 frogs. In oocytes injected with mRNA encoding the $M_{1}$ muscarinic acetylcholine receptor, incubation in PT did not decrease the response to $1 \mu \mathrm{M}$ methylcholine (Figure $2 \mathrm{~B}$ ), 


\section{LYSOPHOSPHATDATE CURRENTS IN OOCYTES}
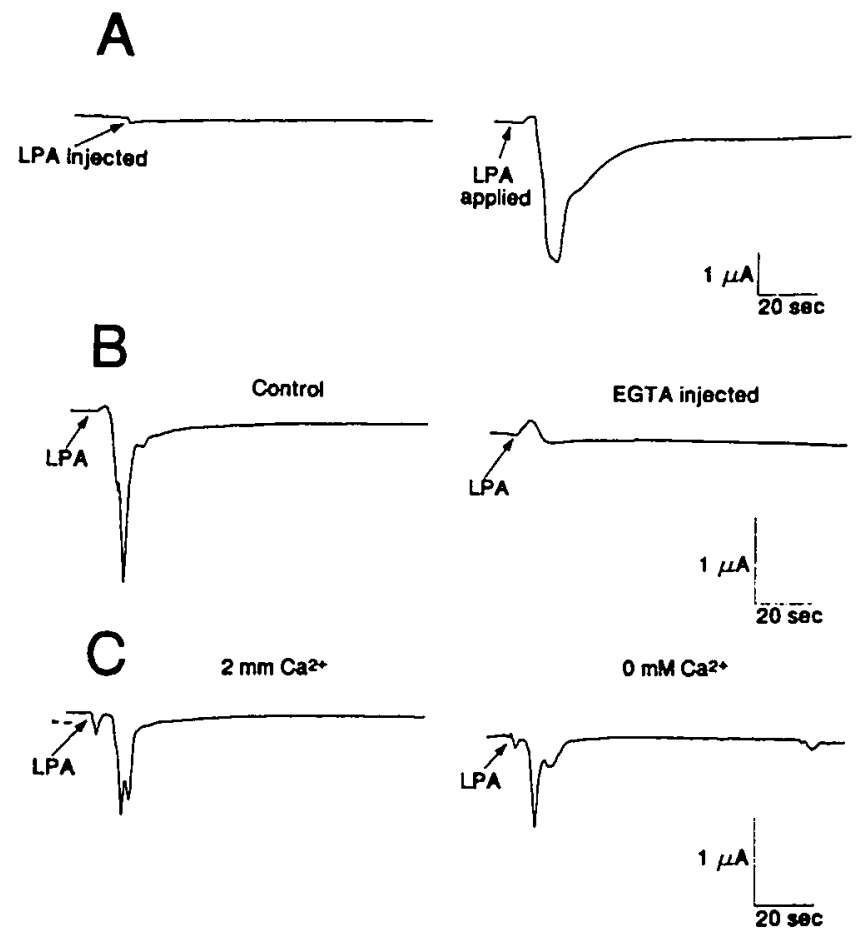

Figure 3. A: LPA $(50 \mathrm{nl}, 10 \mu \mathrm{M})$ injected into defolliculated oocyte at holding potential of $-70 \mathrm{mV}$ does not induce a current. Small deflection seen is attributed to motion artifact induced by injection. LPA applied extracellularly to same oocyte afterwards induces typical current $(19.3 \mu \mathrm{C})$. This suggests an extracellular site of action for LPA. B: Intracellular injection of EGTA (50 nl, $100 \mathrm{nM}$ ) abolishes response to LPA $(100 \mu \mathrm{M})$ in defolliculated oocyte at holding potential of $-70 \mathrm{mV}$. This suggests that LPA response is mediated by intracellular $\mathrm{Ca}^{2+}$. C: LPA $(10 \mu \mathrm{M})$-induced currents in defolliculated oocytes in 0 and $2 \mathrm{mM}$ extracellular $\mathrm{Ca}^{2+}$. Charge movements are 3.5 and $2.8 \mu \mathrm{C}$, respectively.

suggesting that PT did not have a direct effect on intracellular $\mathrm{Ca}^{2+}$ release or on opening of $\mathrm{Ca}^{2+}$-dependent $\mathrm{Cl}^{-}$channels. Thus the LPA effect appears to be mediated through a $\mathrm{G}$ protein-linked pathway.

\section{Oocyte LPA response is a $\mathrm{Ca}^{2+}$-dependent $\mathrm{Cl}$ current}

The $X$. laevis oocyte membrane contains $\mathrm{Ca}^{2+}$-dependent $\mathrm{Cl}^{-}$channels. ${ }^{3}$ To test the hypothesis that the current seen on LPA application was dependent on intracellular $\mathrm{Ca}^{2+}$, we tested oocytes for LPA responses before and after intracellular injection of a 50- to 100-nl volume of $100 \mathrm{mM}$ EGTA (estimated intracellular concentration 5-10 mM). We were unable to elicit the 


\section{CHAPTER 5}

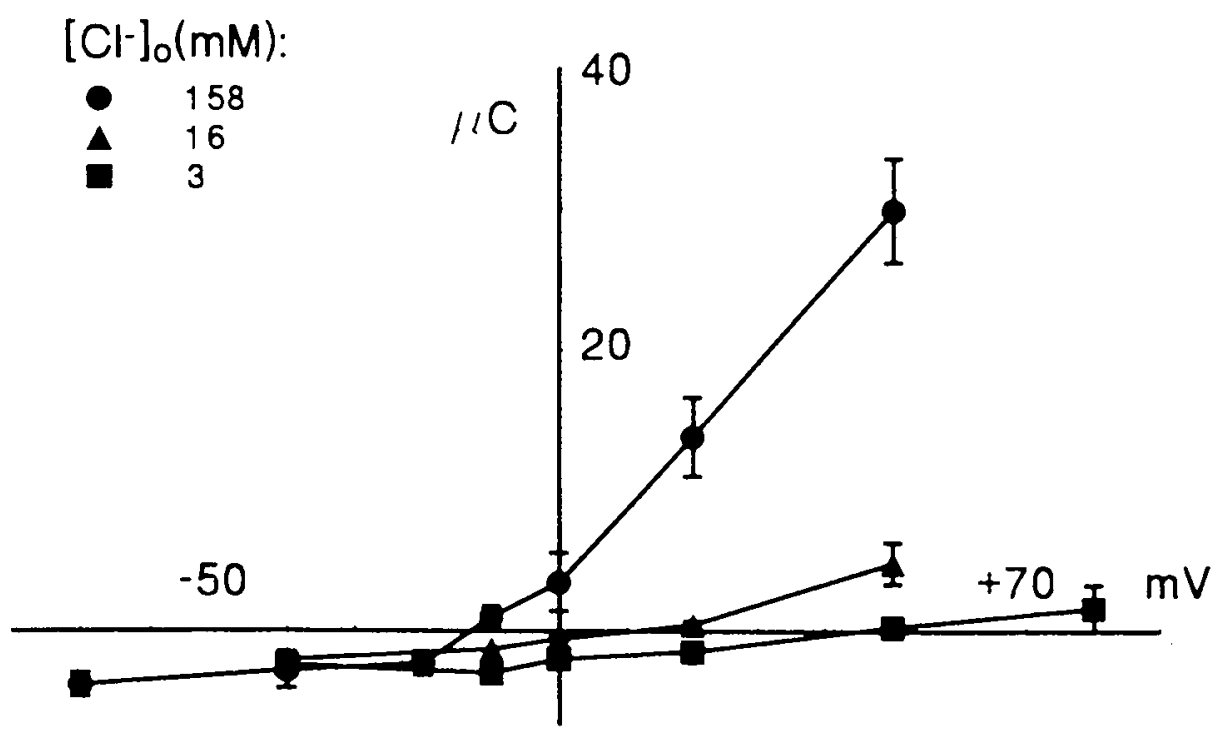

Figure 4. Reversal potential determinations of LPA-induced current in $X$. laevis oocytes. Plot shows charge movement as function of holding potential at $3 \mathrm{Cl}^{-}$concentrations. Each point consists of at least 10 measurements. Error bars indicate SE. Reversal potential: $158 \mathrm{mM} \mathrm{Cl},-15 \mathrm{mV} ; 16$ $\mathrm{mM} \mathrm{Cl}^{-},+10 \mathrm{mV}$; and $3 \mathrm{mM} \mathrm{Cl}^{-},+45 \mathrm{mV}$. This indicates that current is carried mainly by $\mathrm{Cl}^{\circ}$.

LPA effect after EGTA injection (13 oocytes, 2 frogs; Figure 3B), suggesting that intracellular $\mathrm{Ca}^{2+}$ is a mediator of the current. Injection of $50 \mathrm{nl} \mathrm{KCl}(150 \mathrm{mM})$ did not block the response to LPA (data not shown). To determine whether influx of $\mathrm{Ca}^{2+}$ across the cell membrane is important for the response, we recorded LPA-induced currents in oocytes while perfusing the recording chamber with nominally $\mathrm{Ca}^{2+}$-free medium $\left(0 \mathrm{mM} \mathrm{Ca}^{2+}\right.$, no EGTA; 21 oocytes, 3 frogs; Figure $3 \mathrm{C}$ ) as well as with high $(6 \mathrm{mM}) \mathrm{Ca}^{2+}$ medium ( 3 oocytes, 1 frog). In neither case was the magnitude of the induced current affected, suggesting that the response is not dependent on extracellular $\mathrm{Ca}^{2+}$.

To establish the ionic nature of the LPA-induced current, we measured its reversal potential in solutions with different $\mathrm{Cl}^{-}$concentrations (Figure 4). In $158 \mathrm{mM} \mathrm{Cl}^{-}$the reversal potential was approximately $-15 \mathrm{mV}$, in $16 \mathrm{mM} \mathrm{Cl}^{-}$it was $+10 \mathrm{mV}$, and in $3 \mathrm{mM} \mathrm{Cl}-$ it was $+45 \mathrm{mV}$. These findings indicate that the current is mainly carried by $\mathrm{Cl}^{-}$. 

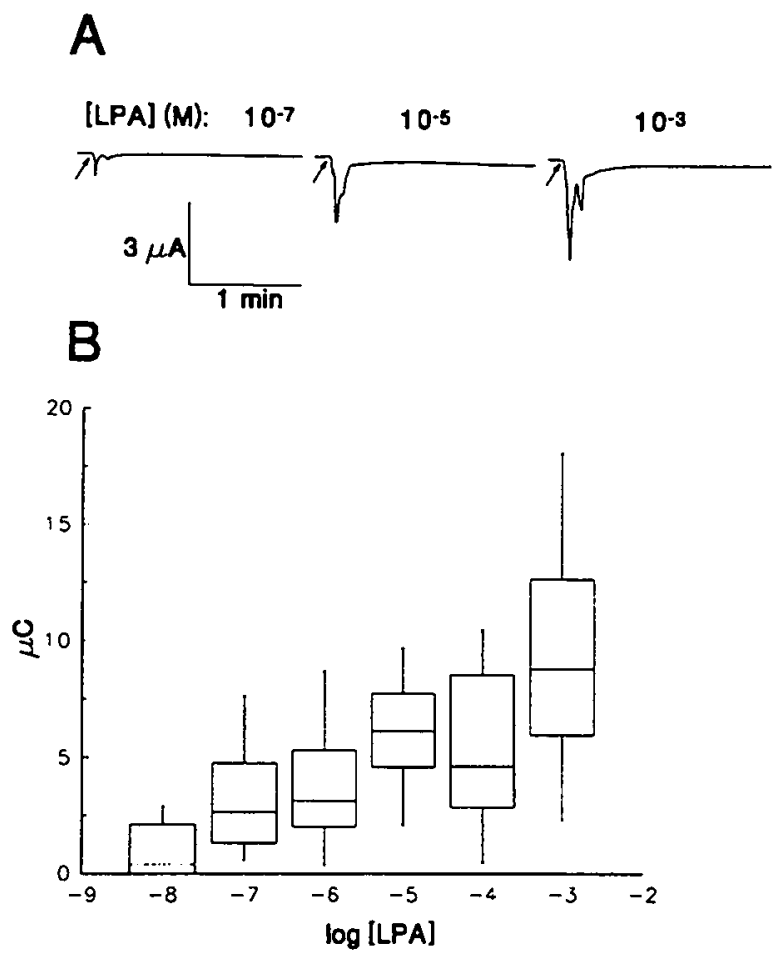

Figure 5. Oocyte LPA response is dose dependent. $A$ : currents induced by 3 concentrations of LPA in defolliculated oocyte at holding potential of $-70 \mathrm{mV}$. Charge movements are $1.37,6.18$, and 9.61 $\mu \mathrm{C}$, respectively. LPA response is dose dependent. $B$ : variability of oocyte response to LPA is demonstrated in this box plot. At least 15 oocytes were tested at each concentration (total 130 oocytes). Each box includes $50 \%$ of measurements; vertical line encompasses $75 \%$. Horizontal line within each box indicates median.

\section{Oocyte LPA response is dose dependent}

The oocyte response to LPA is dependent on the dose applied. Higher concentrations of LPA induced larger currents in individual oocytes (Figure 5A). There was, however, much variability between oocytes, and, even when $>15$ cells were used to determine the average charge movement at each concentration of LPA, we could not demonstrate a sigmoidal dose-response relationship (Figure 5B). This variation was not eliminated by constructing a cumulative dose-response curve (data not shown) nor by testing all doses in a single oocyte, even with copious washes between applications. However, a half-maximal effect was obtained at $\sim 1 \mu \mathrm{M}$ LPA. At concentrations above the critical micellar concentration [ $1.3 \mathrm{mM}(7)]$, we observed a progressive decrease in membrane resistance, possibly due to nonspecific interactions of LPA with the oocyte membrane. 


\section{CHAPTER 5}

\section{LPA does not induce oocyte maturation}

Because LPA induces mitosis in fibroblast lines, ${ }^{2}$ we tested its capability to induce germinal vesicle breakdown (GVBD), the precursor to mitosis in oocytes. Twenty folliculated cells were incubated overnight in $10^{-4} \mathrm{M}$ LPA and were observed under a microscope the next day for the presence of a white spot at the animal pole, an indicator of GVBD. Control oocytes were incubated with progesterone $(5 \mu \mathrm{M})$, which is the physiological inducer of GVBD. The experiment was performed in two sets of oocytes from different frogs. In both cases, $50-60 \%$ of the cells incubated in progesterone showed GVBD, whereas none of the LPA-incubated cells showed this response.

\section{DISCUSSION}

We report that application of LPA to defolliculated $X$. laevis oocytes induces a $\mathrm{Ca}^{2+}$-activated $\mathrm{Cl}^{-}$current. This response is specific for LPA, is dose dependent, and is sensitive to PT. These results suggest that the X. laevis oocyte has a specific receptor for LPA that is linked to a PT-sensitive G protein. Its function is at present unknown but is not related to inducing GVBD. Because the response is present in defolliculated oocytes, this putative receptor is localized on the oocyte itself and not only on the follicle cells. The fraction of the current response blocked by PT incubation puts an upper limit on the amount of LPA effect that can be ascribed to other nonspecific interactions and is $<15 \%$ in our study. During the course of our studies, we learned that others also had observed an inward current in $X$. laevis oocytes induced by LPA application. ${ }^{6}$

Our results have potential limitations. First, PA also induced occasional small currents. These, however, could be due to contamination with LPA, which has been shown to be present in commercial PA sources. ' Alternately, PA is less water soluble than LPA, so the effective concentration might have been lower. Second, it is conceivable that the absence of responses after intracellular LPA application were not a result of the inability of LPA to reach an extracellular site of action but were due to the high intracellular protein concentration that precluded the LPA from ever reaching the membrane and exerting a nonspecific effect.

Nonetheless, our findings are highly suggestive that the LPA response is mediated by an intrinsic oocyte receptor, probably coupled to a PT-sensitive G protein. This receptor would be different from the receptor described on mammalian cells in several ways. In mammalian fibroblasts, the $\mathrm{Ca}^{2+}$ response (but not the mitogenic response) to LPA has been shown to be PT insensitive, 1 so we postulate that either the LPA receptor is linked to a different G protein in $X$. laevis oocytes than in mammalian cells, or amphibian $G$ proteins show a different PT sensitivity. Furthermore, Jalink et al. ${ }^{7}$ demonstrated that the LPA response in fibroblasts is subject to homologous, but not heterologous, desensitization, whereas we found that the oocyte LPA response does not desensitize. However, only after prolonged bath perfusion could full responses again be obtained, possibly indicating that metabolism of LPA at its site of action plays a role in the reappearance of the response. This difference in pharmacological behavior between two species makes the putative LPA receptor an interesting subject for structure-function relationship studies.

The LPA response in $X$. laevis oocytes shows marked variability, and we were unable to establish that the dose dependency of the response falls along a sigmoid curve. We tried multiple approaches using many cells, obtained from several frogs, but obtained similar results in each 


\section{LYSOPHOSPHATDATE CURRENTS IN OOCYTES}

case. The variability could be explained by the many amplification and modulation steps that take place between activation of a receptor and $\mathrm{Cl}^{-}$moving across the cell membrane. More likely, however, is the possibility that the delivery of LPA to its site of action is variable, as a result of its binding affinity for the plasma membrane, micelle formation, and binding to the $B S A$ vehicle. Also, rapid metabolism of LPA might decrease the effective concentration of the drug at its site of action. The concentration at the receptor might therefore be different from the applied concentration and vary from measurement to measurement.

Our findings are of importance for investigators involved in expressing putative membrane receptors in X laevis oocytes. Membrane receptors can activate several phospholipases, not only $C$ but also $D$ and $A 2,{ }^{4,5,10,13}$ and it is therefore conceivable that activation of an expressed receptor could generate LPA in sufficient quantities to activate the oocyte LPA receptor, generating a $\mathrm{Ca}^{2+}$ transient. In that case, an observed current would not be a direct effect of the expressed receptor.

In summary, we report the presence of a novel endogenous response in $X$. laevis oocytes, a $\mathrm{Ca}^{2+}$-activated $\mathrm{Cl}$ current induced by LPA. The response appears mediated by a specific membrane receptor linked to a PT-sensitive G protein.

\section{REFERENCES}

1. van Corven EJ, Groenink A, Jalink A, Eichholtz T, Moolenaar WH: Lysophosphatidate-induced cell proliferation: identification and dissection of signaling pathways mediated by $\mathrm{G}$ proteins. Cell 1989; 59: $45-54$

2. van Corven EJ, van Rijswijk A, Jalink K, van der Bend RL, van Blitterswijk WJ, Moolenaar WH: Mitogenic action of lysophosphatidic acid and phosphatidic acid on fibroblasts. Biochem J 1992; 281: 163-169

3. Dascal N: The use of Xenopus oocytes for the study of ion channels. CRC Crit Rev Biochem $1987 ; 22: 317-387$

4. Exton JH: Signaling through phosphatidylcholine breakdown. J Biol Chem 1990; 265: 1-4

5. Exton JH: Cell signaling through phospholipid breakdown. Mol Cell Biochem 1991; 104: 81-86

6. Fernhout BJH, Dijcks FA, Moolenaar WH, Ruigt GSF: Lysophosphatidic acid induces inward currents in Xenopus laevis oocytes: evidence for an extracellular site of action. Eur J Pharmacol 1992; 213:313-315

7. Jalink K, van Corven EJ, Moolenear WH: Lysophosphatidic acid, but not phosphatidic acid, is a potent $\mathrm{Ca}^{2+}$ mobilizing stimulus for fibroblasts. J Biol Chem 1990; 265: 12232-12239

8. Masu M., Tanabe Y, Tsuchida K, Shigemoto R, Nakanishi S. Sequence and expression of a metabotropic glutamate receptor. Nature 1991; 349: 760-765

9. Moriarty TM, Gillo B, Carty DJ, Premont RT, Landau EM, Iyengar R: $\beta \gamma$-Subunits of GTP-binding proteins inhibit muscarinic receptor stimulation of phospholipase C. Proc Natl Acad Sci USA 1988; 85: 8865-8869

10. Peach MJ, Dostal D: The AngII receptor and actions of AngII. J Cardiovasc Pharmacol 1990; 16: $525-530$

11. Saunders RN, Handley DA: Platelet-activating factor antagonists. Annu Rev Pharmacol Toxicol 1992; 27: 237-255 


\section{CHAPTER 5}

12. Schumacher KA, Classen HG, Späth M: Platelet aggregation evoked in vitro and in vivo by phosphatidic acids and lysoderivatives: identity with substances in aged serum (DAS). Thromb Haemostasis 1979; 42: 631-640

13. Stewart SJ, Cunningham GR, Strupp JA, House FS, Kelley LL, Henderson GS, Exton JH, Bocckino SB: Activation of phospholipase-D-a signaling system set in motion by perturbation of the lymphocyte-T antigen receptor/CD3 complex. Cell Regul 1991; 2: 841-850

14. Tokumura A, Fukuzawa K, Tsukatani H: Effects of synthetic and natural lysophosphatidic acids on the arterial blood pressure of different animal species. Lipids 1978; 13: 572-574

15. Tokumura A, Fukuzawa K, Yamada S, and Tsukatani H: Stimulatory effect of lysophosphatidic acids on uterine smooth muscles of non-pregnant rats. Arch Int Pharmacodyn Ther 1980; 245: 74-83

16. Tokumura A, Yabe N, Fujimoto H, Tsukatani H: LPAs induce contraction of rat isolated colon by two different mechanisms. J Pharm Pharmacol 1991; 43: 774-778 
RESPONSES TO SPHINGOSINE-1-PHOSPHATE IN OOCYTES

\section{CHAPTER 6}

Responses to sphingosine-1-phosphate in $X$. laevis oocytes:

Similarities with lysophosphatidic acid signaling

Marcel E. Durieux

Steve J. Carlisle

Mina N. Salafranca

Kevin R. Lynch

Am J Physiol 1993; 264 (Cell Physiol 33): C1360-C1364

Reproduced with permission from the publisher. 


\title{
Responses to sphingosine-1-phosphate in $X$. laevis oocytes: Similarities with lysophosphatidic acid signaling
}

\begin{abstract}
Sphingosine-1-phosphate (S1P, $50 \mu \mathrm{M}$ ) induces inward currents in Xenopus laevis oocytes voltage clamped at $-70 \mathrm{mV}$. The currents are $\mathrm{Ca}^{2+}$-activated $\mathrm{Cl}^{-}$currents, as shown by a reversal potential of $-20 \mathrm{mV}$ and absence of the response after intracellular injection of ethylene glycol-bis( $\beta$-aminoethyl ether) $-N, N, N^{\prime}, N^{\prime}$-tetraacetic acid (EGTA; $10 \mathrm{mM}$ ). The response is nearly indistinguishable from that to the related compound lysophosphatidic acid (LPA), and complete cross-desensitization occurs between LPA and SIP responses. Both the LPA and SIP responses are inhibited by suramin $(2 \mathrm{mM})$ and dithiothreitol $(5 \mathrm{mM})$. These responses appear mediated by a specific membrane receptor, since intracellular injection of S1P $(5 \mu \mathrm{M})$ does not induce currents, and sphingosine and the related compounds sphingosylphosphorylcholine and $\mathrm{N}, \mathrm{N}$-dimethylsphingosine, all at $100, \mu \mathrm{M}$, neither induce currents nor block the response to S1P. HEK-293 and COS-1 cells respond with intracellular $\mathrm{Ca}^{2+}$ release to both $50 \mu \mathrm{M} \mathrm{SIP}$ and $10 \mu \mathrm{M}$ LPA; K-562 cells do not. No cross-desensitization was noted in the responsive cells. Our findings indicate that S1P and LPA might act through the same mechanism, probably a membrane receptor.
\end{abstract} $\cos -1$

Key words: G protein-coupled receptors; suramin; dithiothreitol; HEK-293; K-562;

\section{INTRODUCTION}

Over the past years several classes of molecules have been shown, unexpectedly, to act as intercellular messengers. Naturally occurring cellular metabolites, because of their ubiquity, were only reluctantly considered as intercellular mediators. However, the demonstration that adenosine, ${ }^{21}$ glutamate, ${ }^{22}$ and $A T P^{17}$ signal through specific G protein-coupled receptors (GCR) has proven this view wrong. There were similar doubts whether highly lipophilic fatty acid derivatives could act through specific membrane receptors. Many investigators favored a direct action on the plasma membrane to explain their effects. Again, however, examples of such compounds acting on receptors or enzymes have now been documented: the prostaglandins, ${ }^{12}$ platelet-activating factor, ${ }^{18}$ the cannabinoids, ${ }^{15}$ and diacylglycerol. ${ }^{11}$

Lysophosphatidic acid (1-acyl-sn-glycerol-3-phosphate, LPA; see Figure 1A) is a phospholipid with a range of cellular actions, including $\mathrm{Ca}^{2+}$ accumulation, platelet aggregation, and cytoskeletal effects. ${ }^{2,19,24,25}$ It is mitogenic for fibroblasts ${ }^{13}$ but inhibits tumor cell growth. ${ }^{6}$ LPA elicits $\mathrm{Ca}^{2+}$-activated $\mathrm{Cl}^{-}$currents in Xenopus oocytes ${ }^{5,7,8}$ and is probably the factor inducing oscillatory currents in these cells on exposure to serum. ${ }^{23}$ Being a natural, albeit minor, membrane constituent and an intermediate in phospholipid biosynthesis, the concept of LPA as a signaling molecule met resistance on both issues mentioned when it was postulated to mediate its varied effects through a specific receptor. However, there is now compelling biochemical evidence that LPA acts through a specific membrane receptor coupled to several $G$ proteins. ${ }^{1,5,24}$ 


\section{RESPONSES TO SPHINGOSINE-1-PHOSPHATE IN OOCYTES}

Recently, there has been increased interest in another phospholipid, sphingosine-l-phosphate (S1P; see Figure 1A) that also induces intracellular $\mathrm{Ca}^{2+}$ transients, ${ }^{9}$ has mitogenic effects in certain cells, ${ }^{27}$ but inhibits growth of tumor lines. ${ }^{20}$ Many researchers expect S1P to have an intracellular site of action, and the possibility of a membrane receptor for this compound has not received much attention. Prompted by the resemblance in structure and effects between LPA and SIP, we studied the relationship between responses to these compounds. In this report, we show the presence, in Xenopus laevis oocytes and several mammalian cell lines, of an endogenous S1P response that shows many similarities with LPA signaling. The SIP response, like the LPA response, might be mediated through a membrane receptor.

\section{MATERIALS AND METHODS}

\section{Materials}

S1P was prepared using the method of van Veldhoven et al. ${ }^{26}$ Briefly, sphingosylphosphorylcholine (Matreya, Pleasant Gap, PA) was treated with phospholipase D (EC 3. 1. 4. 4) from Streptomyces chromofuscus (Sigma, St. Louis, MO), and the product was isolated by selective precipitation in water, acetone, and methanol-chloroform. Purity of the compound was verified by thin-layer chromatography. When developed in $n$-butanol-acetic acid-water (6:2:2 $\mathrm{vol} / \mathrm{vol})$ and sprayed with ninhydrin, a single spot at the expected retardation factor $\left(R_{f} 0.45\right)$ was obtained. In addition, proton nuclear magnetic resonance of the product confirmed the absence of a choline group (data not shown). The compound was dissolved by sonication in $1 \%$ fatty acid-free bovine serum albumin (BSA; ICN Biochemicals, Cleveland, $\mathrm{OH}$ ) in water to a concentration of $\sim 5 \mathrm{mM}$ (assuming a yield of $70 \%$, as reported for this method). Sphingosine and $\mathrm{N}, \mathrm{N}$-dimethylsphingosine were obtained from Matreya and lysophosphatidic acid from Avanti Polar Lipids (Alabaster, AL), and they were dissolved in $1 \%$ BSA. Suramin was obtained from FBA Pharmaceuticals (West Haven, CT). Pertussis toxin was a kind gift of Dr. E. Hewlett at the University of Virginia and obtained from List Biological Laboratories (Campbell, CA). All other chemicals were from Sigma.

\section{Oocyte culture and testing}

Our technique for $X$ laevis oocyte harvesting and culture has been described previously. ${ }^{5}$ Before each experiment, oocytes were defolliculated manually. A single oocyte was placed in a recording chamber filled with $3 \mathrm{ml}$ of a solution containing (in $\mathrm{mM}$ ) $150 \mathrm{NaCl}, 5 \mathrm{KCl}, 1 \mathrm{MgCl}_{2}$, $2 \mathrm{CaCl}_{2}, 10$ dextrose, and $10 \mathrm{~N}$-2-hydroxyethylpiperazine- $\mathrm{N}$-2-ethanesulfonic acid (HEPES; $\mathrm{pH}$ 7.4). Microelectrodes were pulled in one stage from $1.5-\mathrm{mm}$ capillary glass (BBL with fiber; World Precision Instruments, Sarasota, FL) on a micropipette puller (model 700C; David Kopf Instruments, Tujunga, $\mathrm{CA}$ ), and the tips were broken to a diameter of $\sim 10 \mu \mathrm{m}$. They were filled with $3 \mathrm{M} \mathrm{KCl}$, and tip resistances were usually $1-3 \mathrm{M} \Omega$. The cell was voltage clamped using a two-microelectrode voltage clamp amplifier (oocyte clamp OC725A; Warner Corporation, New Haven, CT), connected to a data acquisition system (DAS-8; Keithly Metrabyte, Taunton, MA) running on an IBM-compatible personal computer. Membrane current was sampled at $125 \mathrm{~Hz}$ and recorded for $5 \mathrm{~s}$ before and $55 \mathrm{~s}$ after application of the test compounds. Compounds were delivered in 30- $\mu 1$ aliquots over 1-2 $\mathrm{s}$ using a hand-held micropipettor positioned $\sim 5 \mathrm{~mm}$ from 


\section{CHAPTER 6}

the oocyte. Responses were quantified by integrating the current trace by quadrature and are reported as microcoulombs (means $\pm \mathrm{SE}$ ), since this better reflects $\mathrm{Cl}^{-}$flux than peak current does. ${ }^{5,8}$ All experiments were performed at room temperature. For intracellular injections a third micropipette was used, connected to an automated nitrogen-driven microinjector (PLI-100; Medical Systems, Greenvale, NY). The micropipette was calibrated volumetrically by counting the number of injections needed to expel a known volume of solution. It was then introduced into the cell, and a 50-nl volume was administered. The adequacy of injection was verified by observing the slight increase in cell size on injection.

\section{Cell culture and testing}

HEK-293 cells were obtained from American Type Culture Collection (Rockville, MD) and grown in 1:1 Dulbecco's modified Eagle's medium (DMEM) and F-12 medium containing $10 \%$ fetal bovine serum (FBS). COS- 1 cells were obtained from Derk Bergsma, SmithKline Beecham Pharmaceuticals (Swedeland, PA), and grown in DMEM containing 5\% FBS. K-562 cells were a gift from Dr. Craig L. Slingluff at the University of Virginia and were grown in RPMI medium containing $10 \%$ FBS. All were maintained at $37^{\circ} \mathrm{C}$ in an atmosphere of $5 \% \mathrm{CO}_{2}$. Changes in intracellular $\mathrm{Ca}^{2+}$ concentration $\left(\left[\mathrm{Ca}^{2+}\right]_{i}\right)$ in cultured cell lines were measured using the fluorescent $\mathrm{Ca}^{2+}$ indicator indo-1. Confluent cell layers were removed from the dishes with 6 $\mathrm{ml}$ of a $0.01 \%$ trypsin- $0.02 \%$ EDTA solution, immediately transferred to HEPES-Krebs-Ringer bicarbonate solution (HKRB; in mM: $20 \mathrm{HEPES}, 103 \mathrm{NaCl}, 4.77 \mathrm{KCl}, 0.5 \mathrm{CaCl}_{2}, 1.2 \mathrm{MgSO}_{4}$, $1.2 \mathrm{KH}_{2} \mathrm{PO}_{4}, 25 \mathrm{NaHCO}_{3}$, and 15 glucose, as well as $0.25 \% \mathrm{BSA}, \mathrm{pH} 7.40$ ), and centrifuged for $4 \mathrm{~min}$ at $200 \mathrm{~g}$. Cells were resuspended in HKRB and incubated for $40 \mathrm{~min}$ to $1 \mathrm{~h}$ with $4 \mu \mathrm{M}$ of the acetoxymethyl ester of indo- 1 in $100 \%$ dimethyl sulfoxide at $37^{\circ} \mathrm{C}$. Cells were centrifuged, resuspended to a density of $1.5 \times 10^{6} \mathrm{cells} / \mathrm{ml} \mathrm{HKRB}$, and held at $37^{\circ} \mathrm{C}$ before use. Fluorescence was measured in a temperature-controlled fluorometer (SLM 8000C; SLM Instruments, Urbana, I) at an excitation wavelength of $332 \mathrm{~nm}$ (slit width $2 \mathrm{~nm}$ ) and emission wavelengths of 400 and $485 \mathrm{~nm}$ (slit widths $16 \mathrm{~nm}$ ). $\left[\mathrm{Ca}^{2+}\right]_{\mathrm{i}}$ was calculated from the fluorescence intensity using the method of Lückhoff. ${ }^{14}$ Maximum and minimum fluorescence ratios were calculated by the sequential addition of $75 \mu \mathrm{M}$ digitonin and $5 \mathrm{mM}$ ethylene glycol-bis( $\beta$-aminoethyl ether)- $N, N, N^{\prime}, N^{\prime}$-tetraacetic acid (EGTA), respectively.

\section{RESULTS}

\section{$S I P$ induces $I_{C l(C a)}$ in $\mathrm{X}$. laevis oocytes}

S1P $(50 \mu \mathrm{M})$ induced transient inward currents when applied to oocytes at a holding potential of $-70 \mathrm{mV}$ (Figure $1 \mathrm{~B}$ ). Average charge movement was $-3.9 \pm 0.64 \mu \mathrm{C}$, with some variability between oocytes from different frogs (Figure 2A). The responses developed after a latency of at least $5 \mathrm{~s}$ and occasionally up to $20 \mathrm{~s}$ and consisted of a fast inward component, followed by a recovery over several seconds with superimposed fluctuations. Because this shape is typical for $\mathrm{Ca}^{2+}$-activated $\mathrm{Cl}^{-}$currents in oocytes, we performed experiments to demonstrate the involvement of $\mathrm{Ca}^{2+}$ and $\mathrm{Cl}^{-}$. Intracellular injection of the $\mathrm{Ca}^{2+}$ chelator EGTA (50 nl of 100 $\mathrm{mM}$, intracellular concentration $\sim 10 \mathrm{mM}$ ) inhibited the current completely (5 oocytes from 1 animal; Figure 1 ), suggesting that the response is mediated by a change in $\left[\mathrm{Ca}^{2+}\right]_{\mathrm{i}}$. This is in 

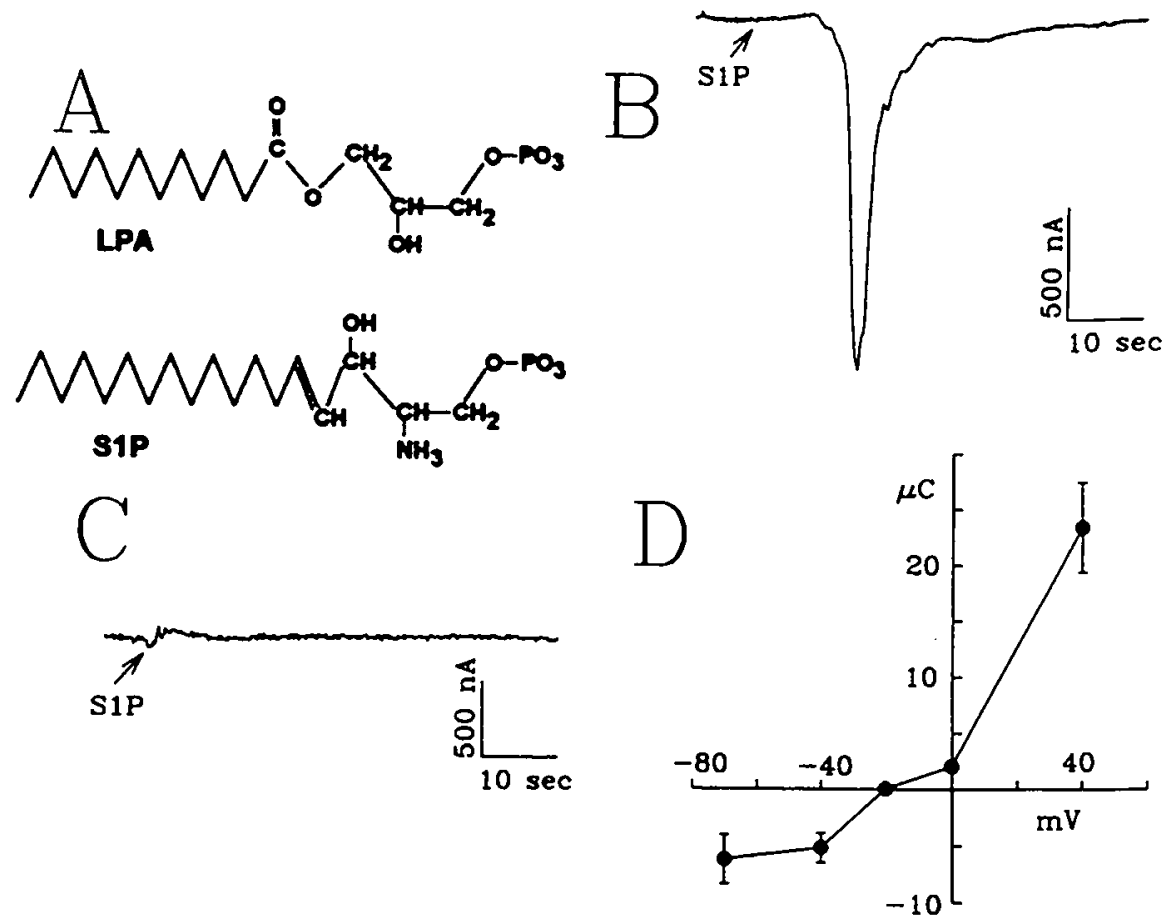

Figure 1. S1P responses in oocytes. $A$ : Molecular structures of sphingosine-1-phosphate (S1P) and lysophosphatidic acid (LPA), indicating their structural similarity. $B$ : Large inward current induced by $50 \mu \mathrm{M} \mathrm{S1P}$ in defolliculated $X$. laevis oocyte voltage clamped at $-70 \mathrm{mV}$. Peak current of SIP response is $1,700 \mathrm{nA}$; total charge movement is $-12 \mu \mathrm{C}$. Bovine serum albumin vehicle did not induce responses. C: Intracellular injection of $50 \mathrm{nl} 100 \mathrm{mM}$ EGTA (intracellular concentration $\sim 10 \mathrm{mM}$ ) inhibits responses to $50 \mu \mathrm{M}$ S1P in defolliculated oocyte at holding potential of $-70 \mathrm{mV}$. This indicates that free intracellular $\mathrm{Ca}^{2+}$ is involved in response. $D$ : Reversal potential determination of S1Pinduced responses in $X$. laevis oocytes. Plot shows charge movement as function of holding potential in solution containing $158 \mathrm{mM} \mathrm{Cl}$. Error bars indicate SEM. Reversal potential is $-20 \mathrm{mV}$, indicating that the current is carried mainly by $\mathrm{Cl}$.

accordance with previous reports of SIP causing intracellular $\mathrm{Ca}^{2+}$ release (9). The measured reversal potential of $-20 \mathrm{mV}$ (Figure $1 \mathrm{D}$ ) indicates that the current is carried mainly by $\mathrm{Cl}-$, presumably through $\mathrm{Ca}^{2+}$-activated $\mathrm{Cl}^{-}$channels known to exist in the oocyte membrane (3). During the first minutes after a S1P response, no further currents could be induced by SIP. However, if the recording chamber was washed with copious amounts of SIP-free solution (150 ml over $30 \mathrm{~min}$ ) multiple responses could be obtained from a single oocyte ( 3 oocytes from 1 animal; data not shown), indicating that tachyphylaxis did not occur. 

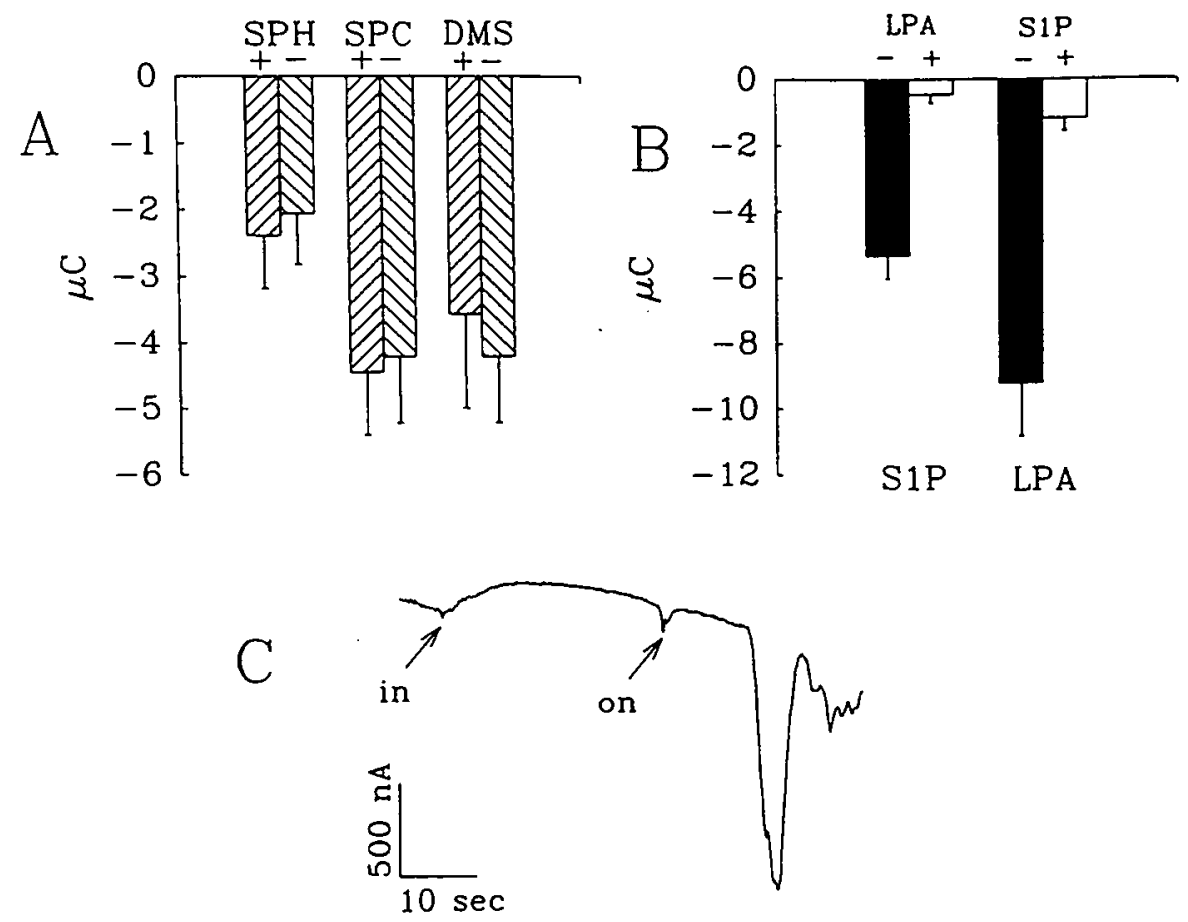

Figure 2. S1P response is specific. $A$ : Responses to $50 \mu \mathrm{M} \mathrm{S1P}$ in defolliculated oocytes voltage clamped at $-70 \mathrm{mV}$, with $(+)$ and without (-) prior application of sphingosine (SPH), sphingosylphosphorylcholine (SPC), or $N, N$-dimethylsphingosine (DMS). SIP response is not affected by these analogues. Note variation in S1P response among batches of oocytes. B: Responses to S1P or LPA in defolliculated oocytes voltage clamped at $-70 \mathrm{mV}$, with $(+)$ or without $(-)$ prior application of LPA or $\mathrm{S} 1 \mathrm{P}$, respectively. There is crossdesensitization between compounds. $C: \mathrm{S} 1 \mathrm{P}(50 \mathrm{nl}, 50 \mu \mathrm{M})$ injected into defolliculated oocyte at holding potential of $-70 \mathrm{mV}$ does not induce inward response, but extracellular application to the same oocyte afterward induces typical $\mathrm{Ca}^{2+}$-activated $\mathrm{Cl}^{-}$current. This suggests extracellular site of action for SIP.

\section{Related sphingolipids do not induce responses}

We tested the S1P analogues sphingosine (11 oocytes from 3 animals), sphingosylphosphorylcholine (lysosphingomyelin; 5 oocytes from 2 animals) and $N, N$-dimethylsphingosine (6 oocytes from 2 animals) for agonist and antagonist activity. When applied at $100 \mu \mathrm{M}$, none of these compounds induced currents in oocytes nor did they block the response to subsequent administration of $50 \mu \mathrm{M}$ S1P (Figure 2A). This lack of response to structurally similar compounds makes nonspecific membrane effects of S1P unlikely. 


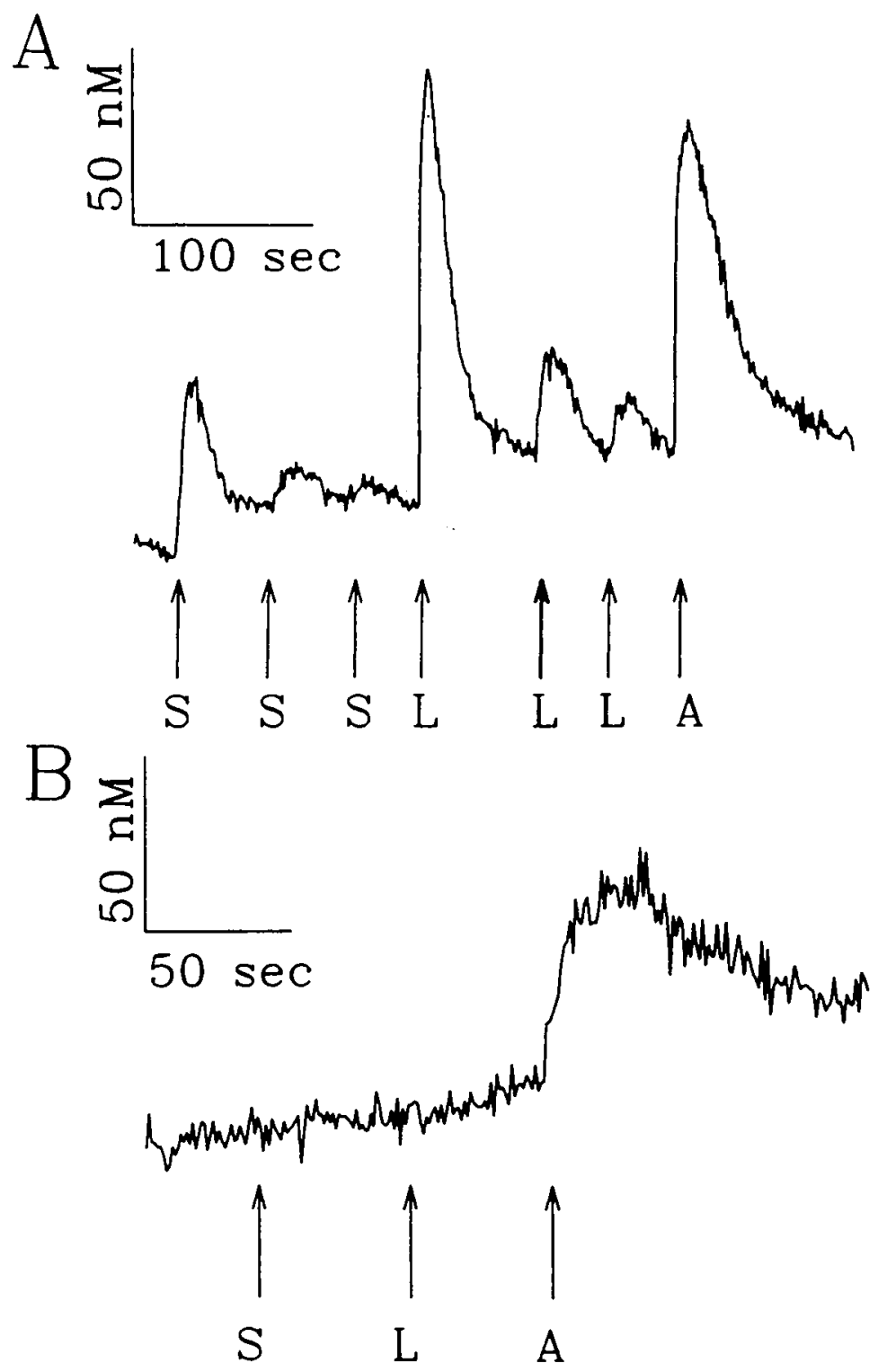

Figure 3. S1P responses in mammalian cells. $A$ : Intracellular $\mathrm{Ca}^{2+}$ concentration ([Ca $\left.\left.{ }^{2+}\right] \mathrm{i}\right)$ measurement by indo-1 fluorescence in HEK-293 cells. Repeated application of $50 \mu \mathrm{M}$ S1P (S) desensitizes response but does not inhibit subsequent responses to $10 \mu \mathrm{M}$ LPA (L). ATP $(10 \mu \mathrm{M} ; \mathrm{A})$ is used to confirm intact signaling mechanism. $B$ : No changes in $\left[\mathrm{Ca}^{2+}\right]_{\mathrm{i}}$ are seen when $50 \mu \mathrm{MS} 1 \mathrm{P}$ or $10 \mu \mathrm{M} \mathrm{LPA}$ are applied to $\mathrm{K} 562$ cells. ATP $(10 \mu \mathrm{M})$ application confirms that $\left[\mathrm{Ca}^{2+}\right]_{\mathrm{i}}$ signaling pathway is intact in these cells. 


\section{CHAPTER 6}

\section{Responses to SIP and LPA cross-desensitize}

We found that a response to the related compound LPA (Figure 1A) consistently inhibited responses to S1P applied subsequently (Figure 2B). Conversely, SIP blocked responses to LPA (Figure 2B). Responses to agonists of other GCRs (muscarinic acetylcholine $M_{1}$ and angiotensin $\Pi$ receptors) expressed in oocytes were not inhibited by prior application of LPA or S1P (data not shown). Because the cross-desensitization suggested that LPA and S1P act through a similar pathway, we studied the concordance between the properties of these compounds more closely.

\section{$S 1 P$ responses appear mediated through a membrane receptor}

In view of the similarities between LPA and S1P responses, we investigated whether the polyanionic compound suramin, which blocks the putative LPA receptor, ${ }^{2,5}$ also inhibited oocyte responsiveness to S1P. At a suramin concentration of $2 \mathrm{mM}$, the response to S1P was decreased by $89 \%$, from $1.58 \pm 0.39$ to $0.18 \pm 0.13 \mu \mathrm{C}$ ( 25 oocytes from 4 animals), similar to its effect on the LPA response. ${ }^{2,5}$ Dithiothreitol (DTT), a disulfide-reducing agent, has been shown to reduce ligand-receptor interaction on several GCR, including the angiotensin II receptor, ${ }^{10}$ presumably by disrupting disulfide bonds in the receptor. When oocytes were incubated for $15 \mathrm{~min}$ in $5 \mathrm{mM}$ DTT, responses to both SIP (11 oocytes from 2 frogs) and LPA (4 oocytes from 1 frog) were eliminated completely. As a control experiment, we expressed the $M_{1}$ muscarinic receptor in oocytes and found that the $\mathrm{Ca}^{2+}$ activated $\mathrm{Cl}^{-}$currents induced by $1 \mu \mathrm{M}$ methylcholine was not sensitive to DTT incubation. These data suggest that a membrane receptor with at least one extracellular disulfide bond might be part of the S1P and LPA signaling pathway. Previously, we reported consistent sensitivity of the oocyte LPA response to pertussis toxin (PT; $2 \mathrm{mg} / \mathrm{ml}$ overnight). ${ }^{5}$ In our present experiments, we found highly variable responses to PT between batches of oocytes, with responses to $10 \mu \mathrm{M}$ LPA consistently inhibited ( $>50 \%$ of control) in only 5 of 15 batches of oocytes. SIP responses were inhibited also in these groups but not in the others. Thus there was complete consistency between LPA and S1P PT sensitivity. To determine further whether S1P acts on an extracellular or intracellular site, we tested the ability of injected $\mathrm{S} 1 \mathrm{P}$ to induce $\mathrm{Ca}^{2+}$-activated $\mathrm{Cl}^{-}$currents. A volume of $50 \mathrm{nl} \mathrm{S1P}$ injected into the oocyte did not induce a current, whereas SIP applied extracellularly to the same oocyte resulted in a charge movement of $-1.68+0.86 \mu \mathrm{C}$ ( 8 oocytes from 2 animals; Figure $2 \mathrm{C}$ ). Similar results have been obtained with LPA. ${ }^{\overline{5,8}}$ This finding indicates that $\mathrm{S} 1 \mathrm{P}$ acts on an extracellular site, rather than on an intracellular target or through nonspecific membrane interactions, and again underscores the similarities between S1P and LPA responses.

The SIP response in mammalian cell lines is different from that in $\mathrm{X}$. laevis oocytes

To study the concordance between S1P and LPA signaling further, we tested several immortalized cell lines for responsiveness to S1P and LPA. COS-1 (5 batches) and HEK-293 (10 batches) cells showed transient intracellular $\mathrm{Ca}^{2+}$ accumulation on stimulation with $50 \mu \mathrm{M} \mathrm{S} 1 \mathrm{P}$ or $10 \mu \mathrm{M}$ LPA (Figure $3 \mathrm{~A}$ ). When we tested the ability of S1P to block responses to subsequent LPA, no inhibition was noted, even after the SIP response was desensitized by several applications of S1P (Figure 3A). Similarly, treatment with LPA did not inhibit S1P responses. Overnight incubation in $5 \mathrm{mM}$ DTT did, but $2 \mathrm{mg} / \mathrm{ml}$ PT did not, reduce responses to LPA or S1P. 


\section{RESPONSES TO SPHINGOSINE-1-PHOSPHATE IN OOCYTES}

$\mathrm{K}-562$ cells ( 7 batches) consistently showed no $\left[\mathrm{Ca}^{2+}\right]_{i}$ changes in response to either S1P or LPA (Figure $3 \mathrm{~B}$ ) but were responsive to ATP and thrombin. In preliminary experiments, $\mathrm{HeLa}, \mathrm{C}_{6}$ glioma, and bovine aortic endothelial cells have been responsive to both LPA and S1P, whereas Jurkat T and EL-4 cells were unresponsive. Therefore we have found complete concordance between responses to LPA and SIP.

\section{DISCUSSION}

We report that application of the phospholipid SIP to Xenopus oocytes results in a $\mathrm{Ca}^{2+}$-activated $\mathrm{Cl}^{-}$current. The SIP response appears mediated through a specific pathway, possibly involving a membrane receptor, and is nearly indistinguishable from the LPA response. In several mammalian cell lines, SiP also induces intracellular $\mathrm{Ca}^{2+}$ accumulation, but through a mechanism that shows several differences with that in oocytes. Our hypothesis that these findings can be explained by LPA and S1P acting through a similar or even identical pathway is difficult to prove conclusively in the absence of binding studies. Nonetheless, our data are consistent with the hypothesis and suggest that a specific membrane receptor might be part of the signaling mechanism. As the lysophospholipid literature bears out, most research groups have focused exclusively on either the glycerol-based or the sphingosine-based family, and the functional and structural similarities between S1P and LPA appear to have gone unnoticed. Our findings suggest that at least some reports of LPA and SIP effects might be addressing the same phenomena.

One potential difficulty with these studies is that the binding to BSA and insolubility of LPA and S1P affect the amount of drug available for interaction with the signaling system, and the concentration applied is probably different from that present at the site of action. There is therefore no inconsistency between the similar magnitude of the responses to LPA and S1P and the differences in concentrations used. Dose-response studies in oocytes with LPA have been unsuccessful, ${ }^{5,7}$ probably due to solubility problems, and therefore we have not attempted establishing a dose-response relationship with the even less soluble S1P.

We were surprised to find significant variability of the oocyte LPA response to PT, whereas in a previous study ${ }^{5}$ we found consistent inhibition. At present, we have no explanation for this result; one possible reason could be seasonal variation in the availability of NAD in the oocyte. The important result, however, is the concordance in sensitivity between SIP and LPA.

The only difference we found between LPA- and S1P-induced currents was a several second longer delay after application of S1P. We cannot determine from our observations whether this longer delay is due to metabolism of S1P to another compound or simply a result of the extreme insolubility of S1P and different dissociation kinetics from the BSA vehicle. It has been shown that, in mammalian cells, S1P induces the formation of phosphatidic acid, ${ }^{4}$ but the time course is at least an order of magnitude too slow to account for the S1P responses we observed.

It is not possible to conclude from the oocyte studies that S1P and LPA act through a membrane receptor, but the cross-desensitization, sensitivity to suramin and DTT, and absence of response after intracellular injection are consistent with that hypothesis. Unfortunately, definitive confirmation of the existence of a SIP receptor and of the identity of the putative LPA and S1P receptors is difficult to obtain. Competition binding studies are virtually impossible due to the heavy membrane partitioning of these lipophilic compounds, resulting in unacceptable 


\section{CHAPTER 6}

levels of nonspecific binding. Also, there is a lack, at present, of specific antagonists for either LPA or S1P. Molecular cloning of the LPA/S1P receptor(s) would be very helpful to settle this issue.

If there is a single LPA/S1P receptor in the Xenopus oocyte, the question arises whether LPA or S1P is the natural ligand for this receptor. This again is not easy to study. It is conceivable, although to our knowledge no precedent exists, that two separate pathways, one resulting in the formation of LPA, the other of S1P, might act through a single receptor as a final common pathway. In mammalian cells, the lack of cross-desensitization is suggestive of the existence of separate LPA and SIP receptors. Again, molecular cloning of the receptors would be helpful in explaining these findings.

In summary, we have demonstrated that $\mathrm{S} 1 \mathrm{P}$ induces $\mathrm{Ca}^{2+}$-activated $\mathrm{Cl}^{-}$currents in Xenopus oocytes. This novel endogenous oocyte response shows a high degree of similarity to, and cross-desensitization with, the response to LPA. In mammalian cells cross-desensitization was not seen, but in the cell types tested to date, there is complete concordance between the $\mathrm{Ca}^{2+}$ transients induced by SIP and those elicited by LPA. Our findings indicate that SIP and LPA act through similar, or even identical, pathways, probably through specific membrane receptors.

\section{REFERENCES}

1. van der Bend RL, Brunner J, Jalink K, van Corven EJ, Moolenaar WH, van Blitterswijk WJ: Identification of a putative membrane receptor for the bioactive phospholipid, lysophosphatidic acid. EMBO J 1992; 11:2495-2501

2. van Corven EJ, van Rijswijk A, Jalink K, van der Bend RL, van Blitterswijk WJ, Moolenaar WH: Mitogenic action of lysophosphatidic acid and phosphatidic acid on fibroblasts: dependence on acyl chain length and inhibition by suramin. Biochem J 1992; 281: 163-169

3. Dascal N: The use of Xenopus oocytes for the study of ion channels. CRC Crit Rev Biochem 1987; 22: 317-387

4. Desai NN, Zhang H, Olivera A, Mattie ME, Spiegel S: Sphingosine-1-phosphate, a metabolite of sphingosine, increases phosphatidic acid levels by phospholipase $\mathrm{D}$ activation. $\mathrm{J}$ Biol Chem 1992; 267: 23122-23128

5. Durieux ME, Salafranca MN, Lynch KR, Moorman JR: Lysophosphatidic acid induces a pertussis toxin-sensitive $\mathrm{Ca}^{2+}$-activated $\mathrm{Cl}^{-}$current in Xenopus laevis oocytes. Am J Physiol 1992; 263 (Cell Physiol. 32): C896-C900

6. Dyer D: The Effects of a Lipid Factor Associated with Serum Albumin on the Growth and Differentiation of Mammalian Cell Lines ( $\mathrm{PhD}$ Thesis). Irvine, CA: Univ. of California, 1992.

7. Ferguson JE, Hanley MR: Phosphatidic acid and lysophosphatidic acid stimulate receptor-regulated membrane currents in the Xenopus laevis oocyte. Arch Biochem Biophys 1992; 297: 388-392, 1992.

8. Fernhout BJH, Dijcks FA, Moolenaar WH, Ruigt GSF: Lysophosphatidic acid induces inward currents in Xenopus laevis oocytes; evidence for an extracellular site of action. Eur J Pharmacol 1992; 213: 313-315

9. Ghosh TK, Bian J, Gill DL: Intracellular calcium release mediated by sphingosine derivatives generated in cells. Science 1990; 248: 1653-1656 


\section{RESPONSES TO SPHINGOSINE-1-PHOSPHATE IN OOCYTES}

10. Gunther S: Characterization of angiotensin II receptor subtypes in rat liver. J Biol Chem 1984; 259: 7622-7629

11. Hannun YA: Lysosphingolipids inhibit protein kinase C: implications for the sphingolipidoses. Science $1987 ; 235: 670-674$

12. Hirata M, Hayashi Y, Ushikubi F, Yokota Y, Kageyana R, Nakanishi S, Narumiya S: Cloning and expression of cDNA for a human thromboxane A2 receptor. Nature 1991; 349: 617-620

13. Jalink K, van Corven EJ, Moolenaar WH: Lysophosphatidic acid, but not phosphatidic acid, is a potent $\mathrm{Ca}^{2+}$ mobilizing stimulus for fibroblasts. J Biol Chem 1990; 265: 12232-12239

14. Lückhoff A: Measuring cytosolic free calcium concentration in endothelial cells with indo-l: the pitfall of using the ratio of two fluorescence intensities recorded at different wavelengths. Cell Calcium 1986; 7: 233-248

15. Matsuda LA, Lolait SJ, Brownstein MJ, Young AC, Bonner TI: Structure of a cannabinoid receptor and functional expression of the cloned cDNA. Nature 1990; 346: 651-564

16. Moriarty TM, Gillo B, Carty DJ, Premont RT, Landau EM, Iyengar R: $\beta \gamma$ Subunits of GTP-binding proteins inhibit muscarinic receptor stimulation of phospholipase C. Proc Natl Acad Sci USA 1988; 85: 8865-8869

17. O'Connor SE: Recent developments in the classification and functional significance of receptors for ATP and UTP, evidence for nucleotide receptors. Life Sci 1992; 50: 1657-1664

18. Prescott SM, Zimmerman GA, McIntyre TM: Platelet-activating factor. J Biol Chem 1990; 265: 17381-17384

19. Ridley AJ, Hall A: The small GTP-binding protein rho regulates the assembly of focal adhesions and actin stress fibers in response to growth factors. Cell 1992; 70: 389-399

20. Sadahira Y, Ruan F, Hakomori S, Igrareshi Y: Sphingosine-1-phosphate, a specific endogenous signaling molecule controlling cell motility and tumor cell invasiveness. Proc Natl Acad Sci USA 1992; 89: 9686-9690

21. Stilea GL: Adenosine receptors. J Biol Chem 1992; 267: 6451-6454

22. Tanabe Y, Masu M, Iahii T, Shigemoto R, Nakanishi S: A family of metabotropic glutamate receptors. Neuron 1992; 8: 169-79

23. Tigyi G, Miledi R: Lysophosphatidates bound to serum albumin activate membrane currents in Xenopus oocytes and neurite retraction in PC12 pheochromocytoma cells. J Biol Chem 1992; 267: 21360-21367

24. Tokomura A, Fukuzawa K, Tsukatani H: Effects of synthetic and natural lysophosphatidic acids on the arterial blood pressure of different animal species. Lipids 1978; 13: 572-574

25. Tokumura A, Fukuzawa K, Yamada S, Tsukatani H: Stimulatory effect of lysophosphatidic acids on uterine smooth muscles of non-pregnant rats. Arch Int Pharmacodyn Ther 1980; 245: 74-83

26. van Veldhoven PP, Foglesong RJ, Bell RM: A facile enzymatic synthesis of sphingosine-1-phosphate and dihydrosphingosine-1-phosphate. J Lipid Res 1989; 30: 611-616

27. Zhang H, Desai NN, Olivera A, Seki T, Brooker G, Spiegel S: Sphingosine-1 phosphate, a novel lipid, involved in cellular proliferation. J. Cell Biol. 1991; 114: 155-167 
OOCLAMP

CHAPTER 7

OoClamp: an IBM-compatible software system for electrophysiologic receptor studies in Xenopus oocytes

Marcel E. Durieux

Comput Meth Prog Biomed 1993; 41: 101-105

Reproduced with permission from the publisher. 


\title{
OoClamp: an IBM-compatible software system for electrophysiologic receptor studies in Xenopus oocytes
}

\begin{abstract}
A software system for IBM-compatible microcomputers running MS-DOS or Microsoft Windows 3.1 is described which facilitates the acquisition, analysis and storage of data from electrophysiologic studies of receptors expressed in Xenopus laevis oocytes. The system is designed to provide standardization of test conditions, automation of all routine functions, rapid, on-line analysis of data, and self-documentation and compact storage of data files. All system settings are optimized for use with the Xenopus expression system, but can be adapted to other large cells. An example application, expression of muscarinic acetylcholine receptors in Xenopus oocytes, is described.
\end{abstract}

Key words: Electrophysiology; Xenopus laevis; Oocytes; Voltage clamp; Receptors

\section{INTRODUCTION}

The oocytes of the African clawed toad Xenopus laevis play an increasingly important role in the study of many membrane ion channels and receptors. Foreign messenger RNA, when injected into these unusually large cells, is translated into protein and inserted into the cell membrane after the appropriate post-translational modifications. The cells can then be studied easily with electrophysiologic or other methods. One particularly helpful feature of the Xenopus oocyte is the presence of $\mathrm{Ca}^{2+}$-activated $\mathrm{Cl}^{-}$channels in the membrane. ${ }^{1}$ These channels pass a $\mathrm{Cl}$ - current $\mathrm{I}_{\mathrm{Cl}(\mathrm{Ca})}$ proportional to the $\mathrm{Ca}^{2+}$ concentration inside the cell.

As many receptors, when stimulated, induce increases in intracellular $\mathrm{Ca}^{2+}$, the function of these receptors can be studied by electrophysiologically measuring $\mathrm{I}_{\mathrm{Cl}(\mathrm{Ca})}{ }^{2}{ }^{2}$ The same assay system also offers a useful approach for cloning the genetic material for such receptors. ${ }^{3}$

This novel concept, electrophysiologic study of membrane receptors, offers significant challenges to existing electrophysiologic hardware and software, as most systems are designed primarily for the study of ion channels in small cells. Xenopus oocytes are several orders of magnitude larger than most cell types, resulting in very high membrane capacitance and necessitating voltage clamp amplifiers with the ability to pass large currents. Several of such 'oocyte amplifiers' are commercially available, but the software needs have not been addressed. Specifically, two problem areas exist. First, $\mathrm{I}_{\mathrm{Cl}(\mathrm{Ca})}$ resulting from receptor stimulation has a much longer time scale (seconds to minutes) than current through most voltage or ligand-gated ion channels (milliseconds to seconds), and available software is not designed to handle these long acquisitions suitably. For example, some electrophysiologic data acquisition programs do not display captured data during acquisition, nor is it possible to abort trials. For experiments on a millisecond time scale this offers no difficulties, but for trials of minutes in duration these are serious disadvantages: a separate oscilloscope is necessary to monitor progress of the experiment, and trials that will yield no useful data (e.g. when clamp oscillation occurs on test compound addi- 
tion) cannot be interrupted. Scale labeling in some packages demonstrates how the software was developed for small cells and short time courses: a typical Xenopus experiment might last an unwieldy '120 $000 \mathrm{~ms}^{\prime}$ (rather than $2 \mathrm{~min}$ ), and yield a current of '5000 nA' (rather than $5 \mu \mathrm{A}$ ). A second problem relates to the need to perform experiments on many oocytes in the most efficient manner possible. Particularly during molecular cloning many hundreds of oocytes need to be tested rapidly, and software optimized for standardization of test conditions, automation of routine functions, rapid analysis, and self-documentation and compact storage of data files will ease the effort considerably. Again, present systems are not designed for such experiments. For example, $\mathrm{I}_{\mathrm{Cl}(\mathrm{Ca})}$ is analyzed most appropriately by integration of the current trace, ${ }^{4,5}$ and most programs do not allow this integration on-line during acquisition.

OoClamp was designed to provide, in combination with an appropriate voltage clamp amplifier and acquisition hardware, an optimized system for acquisition, analysis and storage of $\mathrm{I}_{\mathrm{CI}(\mathrm{Ca})}$ in Xenopus oocytes. Many of the program's features make it useful for the study of other slow currents in large cells. To illustrate the functionality of the program, it was used for acquisition and analysis of $\mathrm{I}_{\mathrm{Cl}(\mathrm{Ca})}$ induced by acetyl- $\beta$-methylcholine in Xenopus oocytes expressing the $\mathrm{M}_{1}$ muscarinic acetylcholine receptor. Another application has been published elsewhere. ${ }^{6}$

\section{PROGRAM DESCRIPTION}

The OoClamp system consists of three programs: (i) OoClamp, which performs all data acquisition and analysis functions and requires the presence of acquisition hardware, (ii) OoCalc, a stand-alone version of the OoClamp analysis module, used to analyze OoClamp data on computers without acquisition hardware, and (iii) OoConv, a utility to convert the compact OoClamp data files to a format that can be imported easily into graphics and spreadsheet programs.

OoClamp runs in $640 \times 480$ color graphics mode, with a $500 \times 350$ pixel screen area reserved for data display. To maximize speed in using the program, all features were designed to be accessed by single-keystroke choices from menus. The program runs in one of three modes: oscilloscope, acquisition, or analysis.

\section{Oscilloscope mode}

This mode shows a real-time trace of the voltage amplifier current output. Under most conditions, this obviates the need for a separate oscilloscope during impalement and stabilization of the oocyte. From this mode, a number of program parameters, optimized for receptor studies in oocytes, can be adjusted, including trial and sweep time (10 s to $2 \mathrm{~min}$ ) and upper and lower screen limits $(-5 \mu \mathrm{A}$ to $+5 \mu \mathrm{A})$. Tick marks can be set for ease of screen reading. An 'auto save' feature controls automatic saving of data files after acquisition and after integration. All these settings are retained when the system is shut down. Acquisition and analysis mode are entered from oscilloscope mode.

\section{Acquisition mode}

Once this mode is entered, the program samples data for the predetermined period, plotting the acquired data in real time. As standardized application of test compounds to the oocyte is desirable, a bell can be set to sound at a preset time into acquisition. Also, a real time clock indi- 
tion) cannot be interrupted. Scale labeling in some packages demonstrates how the software was developed for small cells and short time courses: a typical Xenopus experiment might last an unwieldy '120 $000 \mathrm{~ms}^{\prime}$ (rather than $2 \mathrm{~min}$ ), and yield a current of '5000 nA' (rather than $5 \mu \mathrm{A}$ ). A second problem relates to the need to perform experiments on many oocytes in the most efficient manner possible. Particularly during molecular cloning many hundreds of oocytes need to be tested rapidly, and software optimized for standardization of test conditions, automation of routine functions, rapid analysis, and self-documentation and compact storage of data files will ease the effort considerably. Again, present systems are not designed for such experiments. For example, $\mathrm{I}_{\mathrm{Cl}(\mathrm{Ca})}$ is analyzed most appropriately by integration of the current trace, ${ }^{4,5}$ and most programs do not allow this integration on-line during acquisition.

OoClamp was designed to provide, in combination with an appropriate voltage clamp amplifier and acquisition hardware, an optimized system for acquisition, analysis and storage of $\mathrm{I}_{\mathrm{CI}(\mathrm{Ca})}$ in Xenopus oocytes. Many of the program's features make it useful for the study of other slow currents in large cells. To illustrate the functionality of the program, it was used for acquisition and analysis of $\mathrm{I}_{\mathrm{Cl}(\mathrm{Ca})}$ induced by acetyl- $\beta$-methylcholine in Xenopus oocytes expressing the $\mathrm{M}_{1}$ muscarinic acetylcholine receptor. Another application has been published elsewhere. ${ }^{6}$

\section{PROGRAM DESCRIPTION}

The OoClamp system consists of three programs: (i) OoClamp, which performs all data acquisition and analysis functions and requires the presence of acquisition hardware, (ii) OoCalc, a stand-alone version of the OoClamp analysis module, used to analyze OoClamp data on computers without acquisition hardware, and (iii) OoConv, a utility to convert the compact OoClamp data files to a format that can be imported easily into graphics and spreadsheet programs.

OoClamp runs in $640 \times 480$ color graphics mode, with a $500 \times 350$ pixel screen area reserved for data display. To maximize speed in using the program, all features were designed to be accessed by single-keystroke choices from menus. The program runs in one of three modes: oscilloscope, acquisition, or analysis.

\section{Oscilloscope mode}

This mode shows a real-time trace of the voltage amplifier current output. Under most conditions, this obviates the need for a separate oscilloscope during impalement and stabilization of the oocyte. From this mode, a number of program parameters, optimized for receptor studies in oocytes, can be adjusted, including trial and sweep time ( $10 \mathrm{~s}$ to $2 \mathrm{~min}$ ) and upper and lower screen limits $(-5 \mu \mathrm{A}$ to $+5 \mu \mathrm{A})$. Tick marks can be set for ease of screen reading. An 'auto save' feature controls automatic saving of data files after acquisition and after integration. All these settings are retained when the system is shut down. Acquisition and analysis mode are entered from oscilloscope mode.

\section{Acquisition mode}

Once this mode is entered, the program samples data for the predetermined period, plotting the acquired data in real time. As standardized application of test compounds to the oocyte is desirable, a bell can be set to sound at a preset time into acquisition. Also, a real time clock indi- 


\section{CHAPTER 7}

cates time elapsed since the beginning of the trial, a feature useful for standardization of multiple interventions during a single acquisition. If desired, the acquisition can be aborted at any moment. For maximum efficiency, the system automatically switches to analysis mode at the and of the acquisition, and, if 'auto save' has been activated in oscilloscope mode, stores the acquired data at this point.

OoClamp samples 12-bit data at a fixed rate of $125 \mathrm{~Hz}$. This rate is sufficient both to prevent aliasing of 60 or $50 \mathrm{~Hz}$ noise, the primary noise source for oocyte voltage clamp systems, and to sample adequately the relatively slow changes in current resulting from receptor activation. Sampling is in background (interrupt driven), and is therefore not interrupted or delayed by CPU activity, a feature particularly important when OoClamp is run under Microsoft Windows. A fixed number of 500 data points is used to record each trial, and OoClamp determines the number of $A / D$ conversions averaged to calculate each point as

$$
n=\operatorname{int}\left(\frac{125 * t}{500}\right)
$$

where $t$ is the total acquisition time. Therefore, for a 10 -s trial each data point will be the average of 2 conversions; for a 120 -s trial each point will be the average of 30 conversions.

\section{Analysis mode}

This mode can be entered manually from oscilloscope mode, or automatically after completion of a trial. The primary use of analysis mode is for rapid integration of the current trace. A segment of interest can be highlighted using the cursor keys, and a horizontal cursor is positioned to indicate base line (see Figure 1). With a single keystroke the area delimited is then integrated, using the quadrature method. ${ }^{7}$ If 'auto save' has been activated in oscilloscope mode, the system will also store the data automatically on disk, together with the integration result and the positions of the highlighted segment and base line cursor. If necessary, $Y$-axis scaling and tick settings can be retroactively adjusted to ensure that traces fit on the display, and for ease of reading. The horizontal cursor can also be used to measure current directly, as a digital readout of its position is available (see Figure 1).

From analysis mode files can be saved, and saved files can be loaded for analysis. To maximize speed in using the system, OoClamp generates its own data file names, based on date and a sequential numbering for experiments on each day, resulting in intuitive file names. For example, 'OC060393.14' contains data of the 14th trial run on June 3,1993. This file naming system is not affected by exiting and restarting the system. Similarly, save and load paths, which can be specified separately, are retained when the system is shut down.

Several features are included to increase speed when reviewing large numbers of data files. The date of acquisition only needs to be entered once. Further references to files acquired on that day are simply by number. Also, single-keystroke commands are available to load the next or previous file written on the specified day.

OoClamp data files are designed to use minimal disk space, and to be self-documenting. To minimize the size of data files, only the 500 averaged data points are stored. The time scale is reconstructed during loading from the trial duration, which is stored in the file header. Additional information stored (see Table 1) allows the system to reconstruct completely the screen settings in use as the data were saved. 


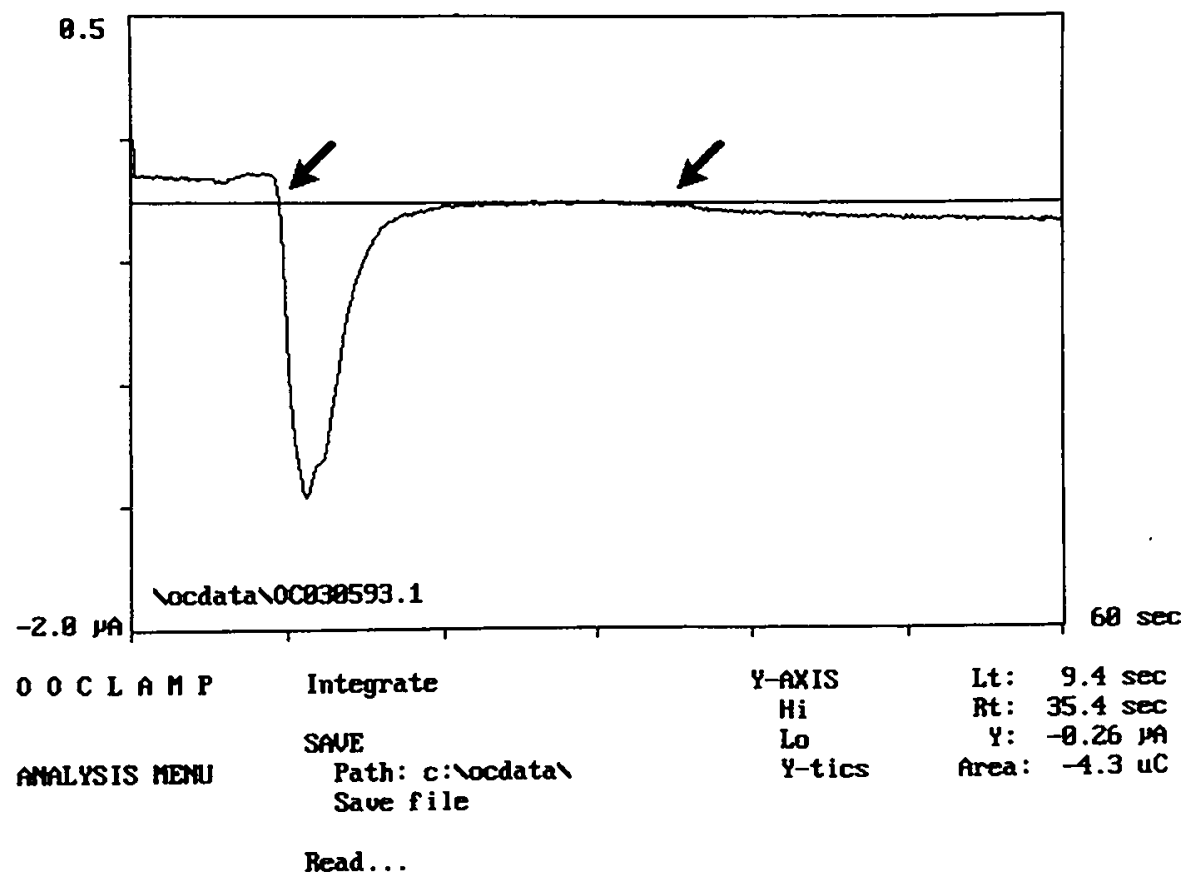

Figure 1. Black-white capture of color screen, demonstrating OoClamp analysis mode. A Xenopus oocyte was injected with $5 \mathrm{ng}$ of the $\mathrm{M}_{1}$ muscarinic acetylcholine receptor (gift of Dr. T.I. Bonner), and cultured for 3 days. The oocyte was defolliculated manually and studied using 2-electrode voltage clamp, using a Oocyte Clamp OC725A (Wamer, New Haven, CT) voltage clamp amplifier. Holding potential was $-70 \mathrm{mV}$. Electrodes were filled with $3 \mathrm{M} \mathrm{KCl}$, and resistances were 1-3 M $\Omega$. Recording chamber contained (in $\mathrm{mM}$ ) $150 \mathrm{NaCl}, 5 \mathrm{KCl}, 1 \mathrm{MgCl}_{2}, 2 \mathrm{CaCl}_{2}, 10$ dextrose, $10 \mathrm{HEPES}$ $(\mathrm{pH}$ 7.4). Acetyl- $\beta$-methylcholine, $30 \mu \mathrm{l}$ of a $1 \mu \mathrm{M}$ solution, was applied to the oocyte $5 \mathrm{~s}$ into the experiment, as marked by a small application artifact. Several seconds later, the large inward $\mathrm{I}_{\left.\mathrm{Cl}_{(\mathrm{C})}\right)}$ demonstrates expression of the receptor. The tracing shows a peak current of approcimately $-1.5 \mu \mathrm{A}$. The segment between 9.4 and $35.4 \mathrm{~s}$ was highlighted (here indicated by arrows), and integrated using the horizontal cursor at $-0.26 \mu \mathrm{A}$ as baseline. Total charge movement over the delimited area was -4.3 $\mu \mathrm{C}$.

\section{Error handling}

OoClamp intercepts and handles 14 different errors. Most of these are used by the system in monitoring the acquisition hardware. The remainder report problems with OoClamp system files, or errors during saving or loading of data files. 
Table 1

File header information stored with OoClamp data files

Name Use

\begin{tabular}{|c|c|}
\hline Max Y value & To reconstruct $\mathrm{Y}$-axis scale \\
\hline Min $Y$ value & To reconstruct $Y$-axis scale \\
\hline $\mathrm{X}$ tick setting & To reconstruct $\mathrm{X}$-axis scale \\
\hline$Y$ tick setting & To reconstruct $\mathrm{Y}$-axis scale \\
\hline Acquisition time & To reconstruct $\mathrm{X}$-axis scale \\
\hline $\begin{array}{l}\text { Horizontal cursor } \\
\text { position }\end{array}$ & $\begin{array}{l}\text { To reconstruct position during } \\
\text { integration }\end{array}$ \\
\hline Left delimiter & $\begin{array}{l}\text { To reconstruct delimited trace } \\
\text { segment }\end{array}$ \\
\hline Right delimiter & $\begin{array}{l}\text { To reconstruct delimited trace } \\
\text { segment }\end{array}$ \\
\hline Integratic & To display \\
\hline
\end{tabular}

OoConv

Due to the compact data storage and the presence of a header with additional information (see Table 1), importing OoClamp data files into other programs is not straightforward. For this reason, a utility program, OoConv, is included. OoConv, using the header information, expands OoCalc data files to ASCII files that can be read easily by graphics and spreadsheet systems.

Hardware and software specifications

OoClamp is designed to work with a Keithley-Metrabyte DAS-8 data acquisition and control board. ${ }^{8}$ No additional software is necessary, as all drivers are included in the OoClamp system. All OoClamp data acquisition functions are performed using standard DAS-8 function calls. A VGA graphics board with either a color or monochrome monitor are also required. The system needs approximately $70 \mathrm{k}$ conventional memory, and will work well in an environment with $128 \mathrm{k}$ left available. OoClamp is written in Microsoft QuickBasic, version 4.5, and has been tested under MS-DOS 5.0 and as a non-Windows application under Microsoft Windows 3.1. 


\section{AVAILABUITY}

Further information concerning the distribution of OoClamp can be requested from the author.

\section{REFERENCES}

1. Dascal N: The use of Xenopus oocytes for the study of ion channels. CRC Crit Rev Biochem 1987; 22: 317-387

2. Straub RE, Oron Y, Gershengorn MC: Expression of mammalian plasma membrane receptors in Xenopus oocytes: studies of thyrotropin-releasing hormone action. Methods Neurosci 1989; 1: 46-61

3. Kushner L, Lerna J, Bennett MVL, Zukin RS: Using the Xenopus oocyte system for expression and cloning of neuroreceptors and channels. Methods Neurosci. 1989; 1: 3-29

4. Fernhout BJH, Dijcks FA, Moolenaar WH, Ruigt GSF: Lysophosphatidic acid induces inward currents in Xenopus laevis oocytes; evidence for an extracellular site of action. Eur J Physiol 1992; 213: 313-315

5. Durieux ME, Salafranca MN, Lynch KR, Moorman JR. Lysophosphatidic acid induces a pertussis toxin-sensitive $\mathrm{Ca}^{2+}$-activated $\mathrm{Cl}^{-}$current in Xenopus laevis oocytes. Am J Physiol 1992; 263: C896-C900

6. Durieux, ME, Carlisle SJ, Salafranca MN, Lynch KR: Responses to sphingosine-l-phosphate in $X$. laevis oocytes: similarities with lysophosphatidic acid signaling. Am J Physiol 1993; 264: $\mathrm{C} 1360-\mathrm{C} 1364$

7. Sprott JC: Numerical Recipes: Routines and Examples in BASIC (Cambridge University Press, 1991)

8. Keithley-Metrabyte DAS-8, DAS-8/PGA, DAS-AO and DAS-8/LT User Manual (Keithley Metrabyte Corporation, 1991) 
TRYPSIN INDUCES CURRENTS IN OOCYTES

CHAPTER 8

Trypsin induces $\mathrm{Ca}^{2+}$-activated $\mathrm{Cl}^{-}$currents in $X$. laevis oocytes

Marcel E. Durieux

Mina N. Salafranca

Kevin R. Lynch

FEBS Lett 1994; 337: 235-238

Reproduced with permission from the publisher. 


\title{
Trypsin induces $\mathrm{Ca}^{2+}$-activated $\mathrm{Cl}^{-}$currents in $\mathrm{X}$. laevis oocytes
}

\begin{abstract}
The protease trypsin induces $\mathrm{Ca}^{2+}$-activated $\mathrm{Cl}^{-}$currents when applied in concentrations as low as $0.1 \mathrm{mg} / \mathrm{ml}$ to defolliculated, voltage clamped $X$. laevis oocytes. The response is dose-dependent and specific, as other proteases (chymotrypsin, Lys-C and Arg-C), or trypsin pretreated with soybean trypsin inhibitor, did not induce currents. Intracellular trypsin injection did not induce responses. The current does not appear to result from proteolytic activation of the endogenous receptor for lysophosphatidic acid, the only known $\mathrm{Ca}^{2+}$-mobilizing receptor consistently present in oocytes. These results suggest the presence on the oocyte membrane of a specific receptor for trypsin.
\end{abstract}

Key words: Oocyte; Xenopus laevis; Trypsin; Voltage clamp; Membrane receptor; Lysophosphatidic acid

\section{INTRODUCTION}

The oocytes of the African clawed toad Xenopus laevis are a tool used commonly for the expression and cloning of membrane receptors of the $G$ protein-coupled receptor superfamily.' One of several advantages of this system is the relative absence of endogenous $\mathrm{Ca}^{2+}$ releaseactivating receptors. Although other agonist-induced responses have been described, particularly to muscarinic agonists, ${ }^{2,3}$ the only responses present consistently in native oocytes are to the phospholipids lysophosphatidic acid (LPA $)^{4-7}$ and sphingosine-1-phosphate (SIP) ${ }^{8}$, which may well signal through the same receptor. To prevent confounding results when expressing receptors in oocytes, it is important for investigators to be aware of the presence of any endogenous signaling systems in these cells. Here we describe the presence of a novel endogenous oocyte response, a Ca ${ }^{2+}$-activated $\mathrm{Cl}^{-}$current induced by the protease trypsin. This response, which is dose-dependent and specific, appears to result from activation of a membrane receptor system.

\section{MATERIALS AND METHODS}

\section{Materials}

LPA (1-oleyl-2-hydroxy-sn-glycero-3-phosphate) was obtained from Avanti Polar Lipids (Alabaster, $\mathrm{AL}$ ) and was dissolved in a $1 \%$ solution of bovine serum albumin (BSA; ICN Biochemicals, Cleveland, OH). The endoproteases Arg-C and Lys-C were obtained from Boehringer-Mannheim (Indianapolis, IN). All other chemicals were obtained from Sigma (St. Louis, $\mathrm{MO})$.

\section{Oocyte culture and testing}

Our technique for Xenopus laevis oocyte harvesting and culture has been described previously. ${ }^{4}$ Prior to each experiment, oocytes were defolliculated manually. A single oocyte was 
placed in a recording chamber filled with $3 \mathrm{ml}$ of a solution containing (mM): $\mathrm{NaCl} 150, \mathrm{KCl} 5$, $\mathrm{MgCl}_{2} 1, \mathrm{CaCl}_{2}$ 2, dextrose 10, HEPES 10 (pH 7.4). Microelectrodes were pulled in one stage from $1.5 \mathrm{~mm}$ capillary glass (BBL with fiber, World Precision Instruments, Sarasota, FL) on a micropipette puller (model 700C, David Kopf Instruments, Tujunga, CA), and the tips were broken to a diameter of approximately $10 \mu \mathrm{m}$. They were filled with $3 \mathrm{M} \mathrm{KCl}$, and tip resistances were usually 1-3 M $\Omega$. The cell was voltage clamped (at $-70 \mathrm{mV}$, unless otherwise noted) using a two-microelectrode voltage clamp amplifier (Oocyte Clamp OC725A, Warner Corp., New Haven, $\mathrm{CT}$ ), connected to an IBM-compatible personal computer with data acquisition hardware (DAS-8, Keithly Metrabyte, Taunton, MA) and software (OoClamp'). Membrane current was sampled at $125 \mathrm{~Hz}$, and recorded for $5 \mathrm{~s}$ before, and $55 \mathrm{~s}$ after, application of the test compounds. Compounds were delivered in $30 \mu \mathrm{l}$ aliquots over 1-2 s using a hand-held micropipettor positioned approximately $5 \mathrm{~mm}$ from the oocyte. Responses were quantified by integrating the current trace by quadrature and are reported as $\mu \mathrm{C}$ (mean \pm S.E.M.). All experiments were performed at room temperature and, unless otherwise noted, at least 5 oocytes were used for each datapoint. For intracellular injections a third micropipette was used, connected to an automated, nitrogen-driven microinjector (PLI-100, Medical Systems Corp., Greenvale, NY). The micropipette was calibrated volumetrically by counting the number of injections needed to expel a known volume of solution. It was then introduced into the cell, and a $50 \mathrm{nl}$ volume was administered. The adequacy of injection was verified by observing the slight increase in cell size on injection.

\section{RESULTS}

Application of trypsin to defolliculated oocytes voltage clamped at a holding potential of $-70 \mathrm{mV}$ induced transient inward currents (see Figure 1A). The responses developed after a latency of several seconds, and consisted of a fast inward component, followed by a fluctuating return to baseline over a period of 5-10 $\mathrm{s}$. Typically, $1 \mathrm{mg} / \mathrm{ml}$ trypsin induced charge transfers of $-2 \mu \mathrm{C}$, but responses could be elicited with concentrations as low as $0.1 \mathrm{mg} / \mathrm{ml}$. The response was dose-dependent within the dose range tested (see Figure 1B). Vehicle alone (BSA $1 \%$ ) did not induce responses. Even if after trypsin application the oocyte was washed for 30 min with trypsin-free solution, no subsequent trypsin responses could be elicited. Therefore, the trypsin response desensitizes completely.

In shape and kinetics these responses are very similar to $\mathrm{Ca}^{2+}$-activated $\mathrm{Cl}^{-}$currents $\left(I_{C I(C a)}\right)$ induced by activation of endogenous or expressed $G$ protein-coupled receptors in Xenopus oocytes. ${ }^{5}$ For this reason we tested the hypothesis that the responses induced by trypsin are

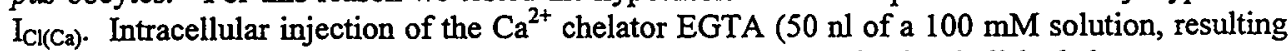
in an approximate intracellular concentration of $5 \mathrm{mM}$ ) completely abolished the response to subsequent application of trypsin (Figure $2 \mathrm{~A}$ ). Therefore, an increase in intracellular $\mathrm{Ca}^{2+}$ level appears to mediate the response. To establish the nature of the ionic current, we elicited responses to trypsin at various holding potentials, and determined the reversal potential of the current (Figure 2B). The reversal potential of $-15 \mathrm{mV}$ at an extracellular $\mathrm{Cl}^{-}$concentration of 158 $\mathrm{mM}$ indicates that the current is carried mainly by $\mathrm{Cl}^{-}$ions. 


\section{CHAPTER 8}
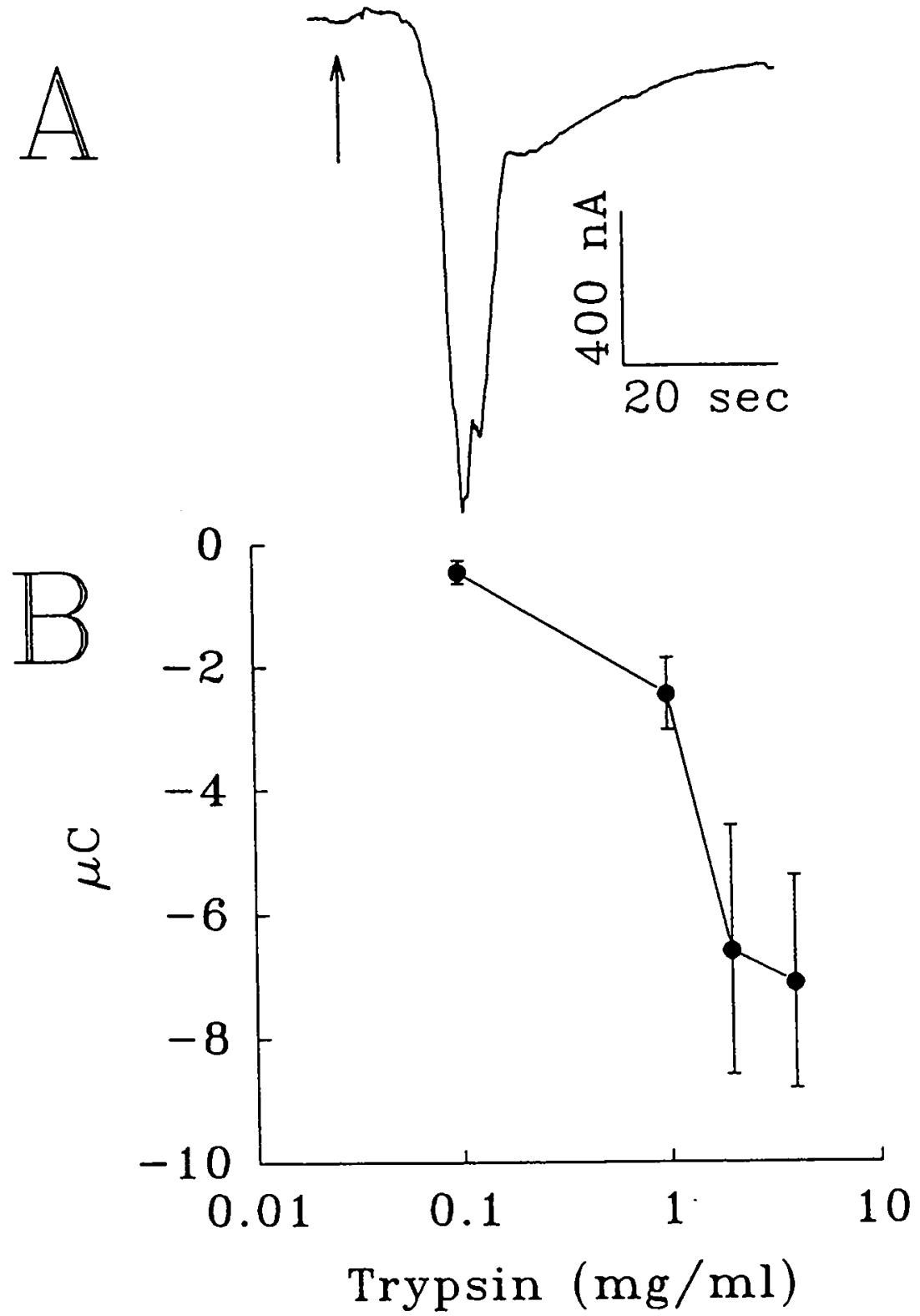

Figure 1. Trypsin-induced currents in Xenopus oocytes. A: When applied (at arrow) to a defolliculated oocyte, voltage clamped at $-70 \mathrm{mV}$, tyypsin $(2 \mathrm{mg} / \mathrm{ml})$ induces an inward current. Charge transfer is -9.4 $\mu C$. $B$ : Dose-dependency of the oocyte response to trypsin. 


\section{TRYPSIN INDUCES CURRENTS IN OOCYTES}
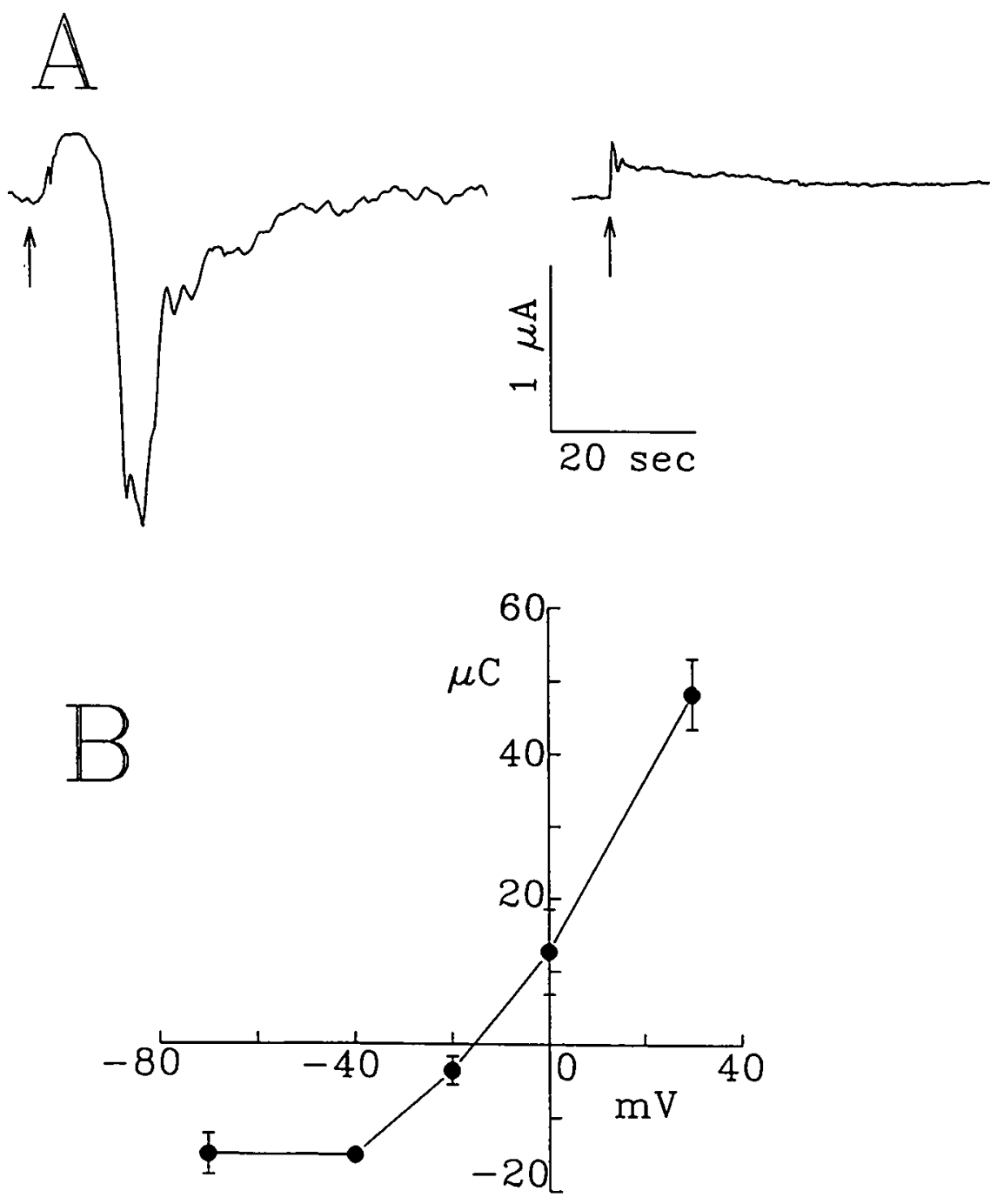

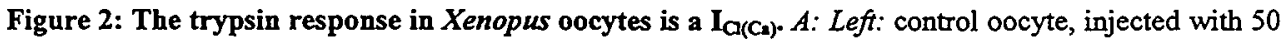
$\mathrm{nl}$ water, and subsequently exposed (at arrow) to trypsin $(1 \mathrm{mg} / \mathrm{ml})$. Charge transfer is $-14.3 \mu \mathrm{C}$. Right: oocyte, injected with $50 \mathrm{nl}$ EGTA $(100 \mathrm{mM})$, and subsequently exposed (at arrow) to trypsin $(1 \mathrm{mg} / \mathrm{ml})$. Except for application artifact, no response is seen, indicating an increase in intracellular $\mathrm{Ca}^{2+}$ concentration mediates the response. Time between injections and applications is approximately 1 minute. $B$. Plot of charge transfer versus holding potential. Each point contains data of at least 5 oocytes. A trypsin concentration of $1 \mathrm{mg} / \mathrm{ml}$ was used. The reversal potential at $-15 \mathrm{mV}$ indicates the current is carried mainly by $\mathrm{Cl}^{*}$ ions. 


\section{CHAPTER 8}

Next, we studied the mechanism of activation of $\mathrm{I}_{\mathrm{Cl}(\mathrm{Ca})}$ by trypsin. To ensure that the responses were due to trypsin, and not to a contaminant, we treated the trypsin solution (1.6 $\mathrm{mg} / \mathrm{ml}$ ) with soybean trypsin inhibitor before application, and found that oocyte responses were virtually eliminated $(-0.4 \pm 0.2 \mu \mathrm{C})$. Trypsin inhibitor alone did not induce responses (data not shown). To determine whether the action of the protease was intracellular or extracellular, we injected trypsin $(50 \mathrm{nl}, 10 \mathrm{mg} / \mathrm{ml})$ into oocytes voltage clamped at $-70 \mathrm{mV}$. No responses were observed, yet viability of the oocytes could be confirmed by responses to $1 \mathrm{mg} / \mathrm{ml}$ trypsin applied subsequently to the outside of the same oocytes, either after 1 minute $(-9.0 \pm 2.1 \mu \mathrm{C}$; see Figure $3 \mathrm{~A})$ or after $5 \mathrm{~min}(-7.5 \pm 1.6 \mu \mathrm{C} ; n=4)$. These responses were similar to those obtained in oocytes injected with $50 \mathrm{nl}$ water $(-11.2 \pm 2.7 \mu \mathrm{C} ; n=3)$. Therefore, an extracellular site of action appears likely. To ascertain that the current did not result from nonspecific proteolysis of membrane constituents, we tested several other proteases for their ability to induce currents. Application of chymotrypsin at a concentration of $1 \mathrm{mg} / \mathrm{ml}$ resulted in small application artifacts only. Similarly, the proteases Arg-C and Lys-C, which cleave a subset of the trypsin cleavage sites, did not induce currents when applied at these concentrations. In addition, responses to trypsin were not reduced by exclusion of $\mathrm{Ca}^{2+}$ from, and addition of, $10 \mathrm{mM}$ EGTA to the bath solution, eliminating trypsin-induced $\mathrm{Ca}^{2+}$ leakage into the oocyte as an explanation of the $\mathrm{I}_{\mathrm{CI}(\mathrm{Ca}) \text {. }}$ Finally, we did not note increases in holding potential after responses to trypsin, indicating the absence of a non-specific increase in membrane leakiness. Thus, the action of trypsin is specific.

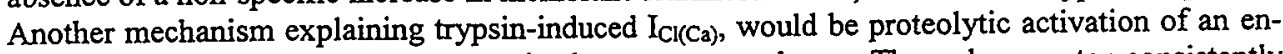
dogenous $G$ protein-coupled receptor in the oocyte membrane. The only receptor consistently present in native oocytes is that for LPA. ${ }^{4-7}$ When activated by LPA this receptor does not desensitize. ${ }^{4,5}$ However, if trypsin activated the LPA receptor by proteolysis one would expect subsequent unresponsiveness to LPA. Therefore, we applied trypsin $(1 \mathrm{mg} / \mathrm{ml})$ to defolliculated oocytes, washed the oocytes in trypsin-free solution for $30 \mathrm{~min}$, and then applied LPA $\left(10^{-5}\right.$ $\mathrm{mM})$. Responses of $-8.7 \pm 2.4 \mu \mathrm{C}$ were obtained, indicating that proteolytic digestion of the LPA receptor had not occurred (Figure $3 \mathrm{~B}$ ).

\section{DISCUSSION}

We report the presence of an endogenous response to trypsin in defolliculated $X$. laevis

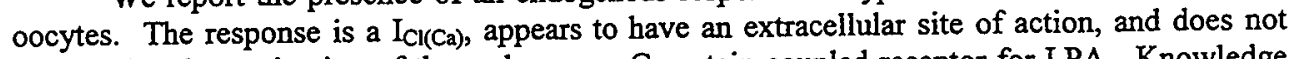
seem to involve activation of the endogenous $G$ protein-coupled receptor for LPA. Knowledge of this response is relevant for researchers using oocytes for expression of $\mathrm{Ca}^{2+}$-mobilizing receptors.

Based on the data presented, it is not possible to determine the signaling mechanism that links the extracellular action of trypsin to the release of intracellular $\mathrm{Ca}^{2+}$. The specificity of the effect makes general destruction of membrane proteins an unlikely explanation. The presence of response in the absence of extracellular $\mathrm{Ca}^{2+}$ eliminates the possibility of trypsin-induced $\mathrm{Ca}^{2+}$ leak. The LPA receptor, the only $G$ protein-coupled receptor known to be present consistently in oocytes, does not appear proteolytically activated. A direct action on the $\mathrm{Cl}_{\mathrm{Ca}}$ channel cannot be ruled out, but appears unlikely, as: (1) the time delay and response kinetics mimic closely those seen during receptor activation, and (2) a (presumably permanent) change in the channel would be unlikely to result in the transient currents observed. Therefore, the most likely explanation for the trypsin responses appears to be the presence of a specific trypsin receptor in these cells. 
A
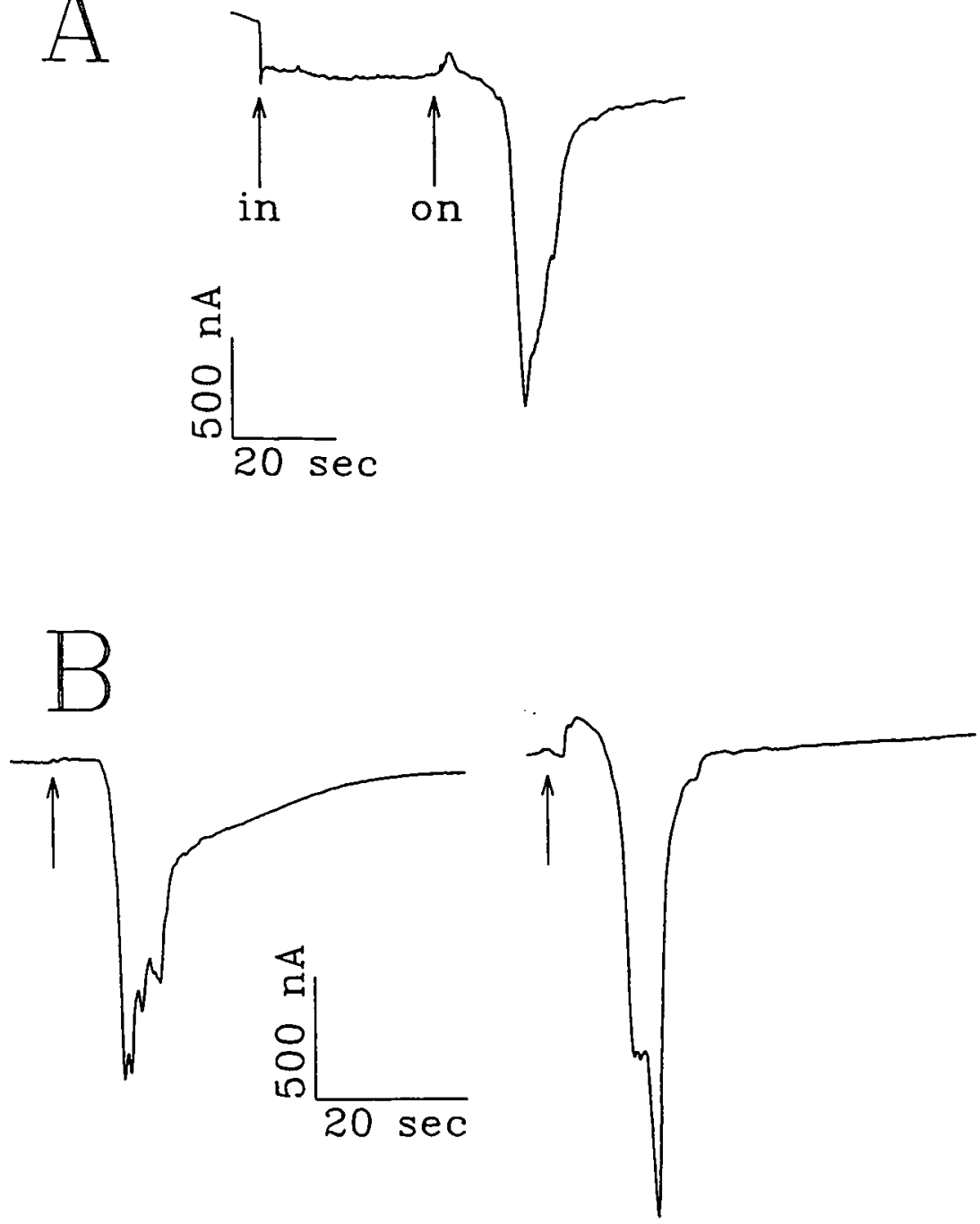

Figure 3. The trypsin response in Xenopus oocytes is mediated through an extracellular system different from the LPA receptor. A: Trypsin $(10 \mathrm{mg} / \mathrm{ml}, 50 \mathrm{ml})$ injected into the oocyte ('in') does not elicit responses whereas trypsin ( $1 \mathrm{mg} / \mathrm{ml}$ ) applied subsequently to the outside of the same oocyte ('on') results in a charge transfer of $-12.5 \mu \mathrm{C}$. Therefore, the site of action is probably extracellular. $B:$ Lef: LPA $\left(10^{-5} \mathrm{M}\right)$ applied to a control oocyte elicits a charge transfer of $-11.1 \mu \mathrm{C}$. Right: after treatment of oocyte with trypsin $(1 \mathrm{mg} / \mathrm{ml})$ and $30 \mathrm{~min}$ wash in trypsin-free solution, LPA $\left(10^{-5} \mathrm{M}\right)$ still elicits a current (charge transfer $-9.2 \mu \mathrm{C}$ ). Therefore, trypsin has not degraded the LPA receptor, making trypsin signaling through this system unlikely. 


\section{CHAPTER 8}

Based on the response morphology, this receptor might belong to the $G$ protein-coupled receptor superfamily. In analogy to the thrombin receptor, another $G$ protein-coupled receptor activated by a protease, this putative trypsin receptor might well be activated through a tethered ligand mechanism. ${ }^{10,11}$ This would explain the complete desensitization of the trypsin response. However, the trypsin doses needed to induce currents are higher than those activating other $G$ protein-coupled receptors, and an altemative explanation of the responses would be trypsin binding, with low affinity, to a receptor in the oocyte membrane for another ligand, as yet unreported. Final determination of the mechanism of action will need additional investigation.

Unresolved at this time is the function of the endogenous trypsin response in oocytes. As $\mathrm{I}_{\mathrm{CI}(\mathrm{Ca})}$ in these cells is presumably a fertilization signal, ${ }^{12}$ the responses to trypsin, LPA or sphingosine-I-phosphate might be involved in signaling that sperm penetration has occurred. Interestingly, in several studies lysophospholipids and trypsin have been shown to have similar effects on components of the reproductive system. Both compounds are able to induce the acrosome reaction and capacitate bovine spermatozoa, ${ }^{14}$ allowing penetration of the zone pellucida of oocytes. Also, a cyclic nucleotide phosphodiesterase has been isolated from Xenopus oocytes that can be activated by trypsin or lysophospholipids, as well as by $\mathrm{Ca}^{2+}$-calmodulin. ${ }^{14}$ Several studies have demonstrated the presence of trypsin-related proteases in the ejaculate of mice ${ }^{15}$ and humans. ${ }^{16}$ The functional relevance of these findings, as well as the relationship, if any, to our finding of an endogenous oocyte $\mathrm{I}_{\mathrm{Cl}\left(\mathrm{C}_{\mathrm{a}}\right)}$ in response to lysophospholipids and trypsin, remains to be evaluated.

\section{REFERENCES}

1. Kushner L, Lerma J, Bennett MVL, Zukin RS: Using the Xenopus oocyte system for expression and cloning of neuroreceptors and channels. Methods Neurosci 1989; 1: 3-29

2. Kusano K, Miledi R, Stinnakre J: Acetylcholine receptors in the oocyte membrane. Nature 1977; 270: 739-741

3. Dascal N, Landau EM: Types of muscarinic receptors in Xenopus oocytes. Life Sci 1980; 27: 1423-1428

4. Durieux ME, Salafranca MN, Lynch KR Moorman JR: Lysophosphatidic acid induces a pertussis toxin-sensitive $\mathrm{Ca}^{2+}$-activated $\mathrm{Cl}^{-}$current in Xenopus laevis oocytes. Am J Physiol 1992; 263: C896-C900

5. Ferguson JE, Hanley MR: Phosphatidic acid and lysophosphatidic acid stimulate receptorregulated membrane currents in Xenopus laevis oocyte. Arch Biochem Biophys 1992; 297, 388-392

6. Femhout BJH, Dijcks FA, Moolenaar WH, Ruigt GSF: Lysophosphatidic acid induces inward currents in Xenopus laevis oocytes; evidence for an extracellular site of action. Eur J Pharmacol 1992; 213: 313-315

7. Tigyi G, Miledi R: Lysophosphatidates bound to serum albumin activate membrane currents in Xenopus oocytes and neurite retraction in PC12 pheochromocytoma cells. J Biol Chem 1992; 67: 21360-21367

8. Durieux ME, Carlisle SJ, Salafranca MN, Lynch KR: Responses to sphingosine-1-phosphate in $X$. laevis oocytes: similarities with lysophosphatidic acid signaling. Am J Physiol 1993; 264: C1360-C1364 


\section{TRYPSIN INDUCES CURRENTS IN OOCYTES}

9. Durieux ME: OoClamp: an IBM-compatible software system for electrophysiologic receptor studies in Xenopus oocytes. Comp Methods Prog Biomed 1993; 41: 101-105

10. Vouret-Craviari V, van Obberghen-Schilling E, Rasmussen UB, Pavirani A, Lecocq JR, Pouyssegur J: Synthetic $\alpha$ thrombin receptor peptides activate $G$ protein-coupled signaling pathways but are unable to induce mitogenesis. Molec Biol Cell 1992; 3: 95-102

11. Scarborough RM, Naughton MA, Teng W et al: Tethered ligand agonist peptides: structural requirements for thrombin receptor activation reveal mechanism of proteolytic unmasking of agonist function. J Biol Chem 1992; 267: 13146-13149

12. Dascal N: The use of Xenopus oocytes for the study of ion channels. CRC Crit Rev Biochem $1987 ; 22: 317-387$

13. Wheeler MB Seidel GE: Capacitation of bovine spermatozoa by lysophospholipids and trypsin. Gamete Res 1989; 22: 193-204

14. Orellana O, Jedlicki E, Allende CC, Allende JE: Properties of a cyclic nucleotide phosphodiesterase of amphibian oocytes that is activated by calmodulin and calcium, by try tic proteolysis, and by phospholipids. Arch Biochem Biophys 1984; 231 : 345-354

15. Huarte J, Belin D, Bosco D, Sappino AR, Vassalli JD: Plasminogen activator and mouse spermatozoa: urokinase synthesis in the male genital tract and binding of the enzyme to the sperm cell surface. J Cell Biol 1987; 1281-1289

16. Huarte J, Belin D, Vassalli JD: Occurrence of both urokinase and tissue plasminogen activator in human seminal plasma. Thromb Res 1979; 16: 463-472 

PROPOFOL AND LYSOPHOSPHATIDATE SIGNALING

CHAPTER 9

Interactions between propofol and lipid mediator receptors:

Inhibition of lysophosphatidate signaling

Mario A. Rossi

Carrie K. Chan

Jared D. Christensen

Emily J. DeGuzman

Marcel E. Durieux

Anesth Analg 1996; 83: 1090-1096

Reproduced with permission from the publisher. 


\section{CHAPTER 9}

\section{Interactions between propofol and lipid mediator receptors: Inhibition of lysophosphatidate signaling}

\section{ABSTRACT}

As a highly lipophilic drug, propofol may interact with lipophilic domains in addition to its likely primary site of action on the $\gamma$-aminobutyrate ${ }_{A}\left(G_{A B A}\right)$ receptor. Likely candidates for such interaction are the $G$ protein-coupled membrane receptors for lipid intercellular mediators. The phospholipid lysophosphatidate (LP) has attracted attention as such a signaling molecule. It has a variety of biological actions, including vasoconstriction. We therefore studied the interaction between propofol and the LP receptor. Intracellular $\mathrm{Ca}^{2+}$ release in response to LP was assessed by measuring $\mathrm{Cl}^{-}$flux through $\mathrm{Ca}^{2+}$-activated $\mathrm{Cl}^{-}$channels in Xenopus oocytes. The average charge movement in response to $\mathrm{LP} 10^{-7} \mathrm{M}$ was $2.0 \pm 0.2$ microCoulombs. Propofol in Intralipid ${ }^{\otimes}(0.01 \%)$ dose-dependently inhibited LP signaling $(50 \%$ inhibitory concentration $\left.\left[\mathrm{IC}_{50}\right] 5.38 \mu \mathrm{M}\right)$. Propofol $28 \mu \mathrm{M}$ inhibited LP signaling by $81 \%$. Intralipid ${ }^{\circledR}(0.01 \%)$ was without effect. To ascertain that intracellular signaling pathways and the $\mathrm{Ca}^{2+}$-activated $\mathrm{Cl}^{-}$channel were not affected by propofol, we tested the effects of propofol $(5.6 \mu \mathrm{M})$ on currents induced by methylcholine $\left(10^{-7} \mathrm{M}\right)$ in oocytes expressing the ml muscarinic acetylcholine receptor. No inhibition was observed. As both receptors share the same intracellular signaling pathway, we conclude that clinically relevant concentrations of propofol most likely inhibit the LP receptor or its $G$ protein. Inhibition of LP signaling may explain some of propofol's vasodilating actions.

Key words: General anesthetics: propofol; Xenopus laevis; Receptors: lysophosphatidate, muscarinic acetylcholine

\section{INTRODUCTION}

Propofol (2,6-diisopropylphenol) has rapidly established itself as one of the most commonly used intravenous anesthetics. Like the benzodiazepines, the barbiturates, and etomidate, its likely primary site of action appears to be the $\gamma$-aminobutyrate ${ }_{A}\left(G A B A_{A}\right)$ receptor-channel complex. ${ }^{-3}$ However, propofol is significantly more lipophilic than these other GABAergic anesthetics. Therefore, it might be expected to interact with additional sites in the central nervous system and the periphery; such interactions might explain some of the compound's specific secondary effects, such as peripheral and coronary vasodilation. ${ }^{4}$

Of particular interest as sites of propofol action are the receptors for lipophilic mediators. Whereas until recently it was considered unlikely that hydrophobic molecules could act as intercellular mediators, several classes of such lipid-derived compounds have now been well described. The prostaglandins and leukotrienes are prominent examples, and a novel group of phosphate-containing compounds, including lysophosphatidate ${ }^{5,6}$ and sphingosine-1-phosphate, ${ }^{7}$ has recently attracted much attention. An intracellular analog of such lipid signaling compounds is diacylglycerol, the second messenger that activates protein kinase $C$.

Lysophosphatidate (1-oleoyl-2-hydroxy-sn-glycero-3-phosphate; LP) signaling has been described in considerable detail over the past years. ${ }^{5,6,8}$ The compound has a variety of actions in 


\section{PROPOFOL AND LYSOPHOSPHATDATE SIGNALING}

various preparations: it contracts smooth muscle, aggregates platelets, is mitogenic in fibroblasts, and induces morphologic changes in neurons and other cells. In many cell types it releases intracellular $\mathrm{Ca}^{2+}$ and decreases cyclic adenosine monophosphate levels. These effects are mediated through a $G$ protein-coupled membrane receptor. The compound is a simple phospholipid (Figure 1A) and is quite hydrophobic. Since the binding site on the LP receptor is presumably hydrophobic as well, we hypothesized that propofol might interact with this LP receptor. Such interaction could explain some of propofol's vasodilating properties.

We therefore studied the effects of clinical concentrations of propofol on LP signaling. As a model system we used Xenopus laevis oocytes. These cells have an endogenous, well described LP signaling system linked to intracellular $\mathrm{Ca}^{2+}$ release, which is quantified conveniently by measuring current through $\mathrm{Ca}^{2+}$-activated $\mathrm{Cl}^{-}$channels $\left(\mathrm{I}_{\mathrm{Cl}(\mathrm{Ca})}\right.$, Figure $\left.1 \mathrm{~B}\right){ }^{7,9}$ In addition, the size of the cells makes them very accessible and easily studied. To localize the site of action of propofol, we compared its effect on LP signaling with that on recombinantly expressed ml muscarinic acetylcholine receptors, which signal through the same intracellular pathway. Specifically, we attempted to answer the following questions: 1) Does propofol, in clinically relevant concentrations, affect signaling through LP receptors? 2) If so, in which segment of the signal-

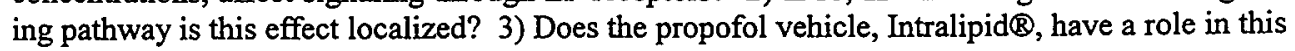
effect?

\section{METHODS}

The study protocol was approved by the Animal Research Committee at the University of Virginia.

\section{Oocyte harvesting}

Female $X$. laevis toads were obtained from Xenopus I (Ann Arbor, MT), housed in an established frog colony, and fed regular frog brittle twice weekly. For removal of oocytes, a frog was immersed in $7.65 \mathrm{mM}$ solution of tricaine until unresponsive to a painful stimulus (toe pinching). A 1-cm long incision was made in a lower abdominal quadrant and a lobule of ovarian tissue, containing approximately 200 oocytes, was removed and placed in modified Barth's solution (containing in mM: $\mathrm{NaCl} 88, \mathrm{KCl} 1, \mathrm{NaHCO}_{3} 2.4, \mathrm{CaCl}_{2} 0.41, \mathrm{MgSO}_{4} 0.82, \mathrm{Ca}_{2}\left(\mathrm{NO}_{3}\right)_{2}$ 0.3 , gentamicin 0.1 , HEPES $15 ; \mathrm{pH}$ adjusted to 7.6 ). The wound was closed in two layers, and the animal was allowed to recover in a separate tank overnight.

The ovarian tissue was washed immediately with modified Barth's solution and dissected into small clusters of 20-50 oocytes. Mature oocytes (Dumont Stage V and VI) were isolated and the follicular layer was removed manually from each oocyte using microforceps.

\section{Receptor expression}

LP receptors are expressed endogenously in Xenopus oocytes. The rat ml muscarinic acetylcholine receptor was expressed recombinantly. Its complementary DNA (cDNA) consists of a 2.8-kilobasepair fragment in a commercial vector (pGEM1; Promega, Madison, WI). The construct was linearized by digestion with the nuclease Hind III, and complementary RNA (cRNA) was transcribed in vitro using the bacteriophage RNA polymerase T7. A capping ana- 


\section{CHAPTER 9}

$\log \left({ }^{7 \mathrm{~m}} \mathrm{GpppG}\right)$ was included in the reaction to generate capped transcripts, as these are translated more efficiently in the oocyte. The resulting mRNA was quantified by spectroscopy and diluted in water to a concentration of $0.1 \mathrm{mg} / \mathrm{mL}$. Oocytes were each injected with $3.5-5 \mathrm{ng}$ of ml muscarinic receptor mRNA using an automated microinjector (Nanoject; Drummond Scientific, Broomall, PA). Adequacy of injection was confirmed by noting the slight increase in cell size during injection. The cells were then cultured in modified Barth's solution at $18^{\circ} \mathrm{C}$ for 3 days before study.

\section{Electrophysiology}

A single defolliculated oocyte was placed in a perfusable recording chamber $(3 \mathrm{~mL}$ volume) filled with Tyrode's solution (containing in $\mathrm{mM}: \mathrm{NaCl} 150, \mathrm{KCl} 5, \mathrm{MgCl}_{2} 1, \mathrm{CaCl}_{2}$ 2, dextrose 10, HEPES 10; pH adjusted to 7.4). Microelectrodes were pulled in one stage from capillary glass (BBL with fiber; World Precision Instruments, Sarasota, FL) on a micropipette puller (model 700C; David Kopf Instruments, Tujunga, CA). Tips were broken to a diameter of approximately $10 \mu \mathrm{m}$, providing a resistance of $1-3 \mathrm{M} \Omega$. Electrodes were filled with $3 \mathrm{M} \mathrm{KCl}$.

The cell was voltage clamped using a two microelectrode oocyte voltage clamp amplifier (OC725C; Warner Corporation, New Haven, CT) connected to a data acquisition and analysis system running on an IBM-compatible personal computer. The acquisition system consisted of a DAS-8 A/D conversion board (Keithley-Metrabyte, Taunton, MA) and analysis was performed with OoClamp software. ${ }^{10}$ Holding potential was $-70 \mathrm{mV}$. Cells that did not show a stable holding current of less than $1 \mu \mathrm{A}$ during a 1 -min equilibration period (less than $5 \%$ of cells tested) were excluded from analysis. Membrane current was sampled at $125 \mathrm{~Hz}$ and recorded for $5 \mathrm{~s}$ before and $55 \mathrm{~s}$ after application of the test compounds.

\section{Drug application}

LP was dissolved in $1 \%$ bovine serum albumin (fatty acid free). To ensure that the hydrophobic LP was in solution, it was vortexed vigorously and sonicated (Benson 250 Sonifier, Danbury, CT) at $5 \%$ output in two 5-s intervals each day before use.

Propofol was added to the bath as a $30-\mu \mathrm{L}$ volume of 100 -fold concentrated stock in $1 \%$ Intralipid $^{\otimes}$ (an intravenous fat emulsion) in Tyrode's solution (final Intralipid ${ }^{\otimes}$ concentration $0.01 \%$ for all propofol concentrations), and $1 \mathrm{~min}$ was allowed for equilibration. The agonist (methylcholine $10^{-7} \mathrm{M}$ for ml muscarinic-injected oocytes; LP $10^{-7} \mathrm{M}$ for uninjected oocytes) was then delivered in a $30-\mu \mathrm{L}$ aliquot over $1-2 \mathrm{~s}$ using a micropipettor positioned approximately $5 \mathrm{~mm}$ from the oocyte.

Intralipid ${ }^{\Phi}$ was added to the bath as a $30-\mu \mathrm{L}$ volume of 100 -fold concentrated $1 \%$ stock (final concentration $0.01 \%$ ), and $1 \mathrm{~min}$ was allowed for equilibration. LP was then delivered to the oocyte in the same manner as in the propofol experiments. All experiments were performed at room temperature.

\section{Data analysis}

$\mathrm{I}_{\mathrm{Cl}(\mathrm{Ca})}$ was used as a measure of agonist-induced $\mathrm{Ca}^{2+}$-release. Responses were quantified by integrating the current trace by quadrature and are reported as charge movements in units of microCoulombs, as this reflects $\mathrm{Ca}^{2+}$ release better than peak current does. ${ }^{9}$ 
Responses are reported as mean \pm SEM. As variability between batches of oocytes is common, responses were normalized to controls from the same batch to allow inclusion of data from multiple frogs into the same comparison. Oocytes from at least two frogs were used for each treatment. Differences between treatment groups were analyzed using Student's unpaired t-test. $\mathrm{P}<0.05$ was considered significant.

\section{Materials}

The rat $\mathrm{ml}$ muscarinic acetylcholine receptor cDNA was obtained from Dr. T. I. Bonner (National Institute of Mental Health, Bethesda, MD). LP was obtained from Avanti Polar Lipids (Alabaster, AL). Bovine serum albumin was obtained from ICN Biomedicals (Cleveland, $\mathrm{OH}$ ). Propofol was obtained from Zeneca Pharmaceuticals (Wilmington, DE). Intralipid ${ }^{\circledast}$ was obtained from KabiVitrum Inc. (Alameda, CA). Molecular biology reagents were obtained from Promega (Madison, WD). All other chemicals were obtained from Sigma (St. Louis, MO).

\section{RESULTS}

\section{LP signaling}

Uninjected oocytes responded to lysophosphatidate LP $10^{-7} \mathrm{M}$ with a transient inward current (Figure 1C). The current developed after a latency of $\geq 1 \mathrm{~s}$ and consisted of a fast inward component followed by a relaxation over several seconds, on which small fluctuations were superimposed. This is the typical response pattern to LP in these cells. ${ }^{9}$ Average charge movement in response to $L P 10^{-7} \mathrm{M}$ was $2.0 \pm 0.2 \mu \mathrm{C}(\mathrm{n}=65)$. We have previously shown that this response to $\mathrm{LP}$ is specific and represents a $\mathrm{Cl}^{-}$flux through $\mathrm{Ca}^{2+}$-activated $\mathrm{Cl}^{-}$channels. ${ }^{9}$

\section{Effects of propofol on LP signaling}

We then tested the ability of propofol to interfere with LP signaling. Propofol in clinically relevant concentrations (2.8-28 $\mu \mathrm{M})$ did not elicit responses in uninjected oocytes (data not shown), but depressed LP-induced currents in a dose-dependent manner. Sample traces showing typical responses to $L P 10^{-7} \mathrm{M}$ in the presence of various concentrations of propofol are shown in Figure $2 \mathrm{~A}$, whereas Figure $2 \mathrm{~B}$ represents the concentration-response relationship. Curve fitting to the Hill equation yielded a $50 \%$ inhibitory concentration $\left(\mathrm{IC}_{50}\right)$ of $5.38 \mu \mathrm{M}$ and a slope of 5.74. Propofol in a concentration of $28 \mu \mathrm{M}$ depressed the LP response by $81 \%$. This incomplete inhibition by large propofol concentrations suggests that the effect of propofol on LP signaling may not be exclusively competitive antagonism.

To exclude effects on LP signaling of the Intralipid ${ }^{\otimes}$ solvent, its ability to interfere with LP signaling was also tested. Intralipid ${ }^{\otimes}(0.01 \%)$ did not elicit responses in uninjected oocytes (data not shown), nor did it inhibit responses to LP. The average LP response in the presence of Intralipid $^{\otimes}$ was $2.1 \pm 0.4 \mu \mathrm{C}$, similar to the control response $(1.8 \pm 0.5 \mu \mathrm{C}$ ) (Figure $2 \mathrm{C}$ ). 

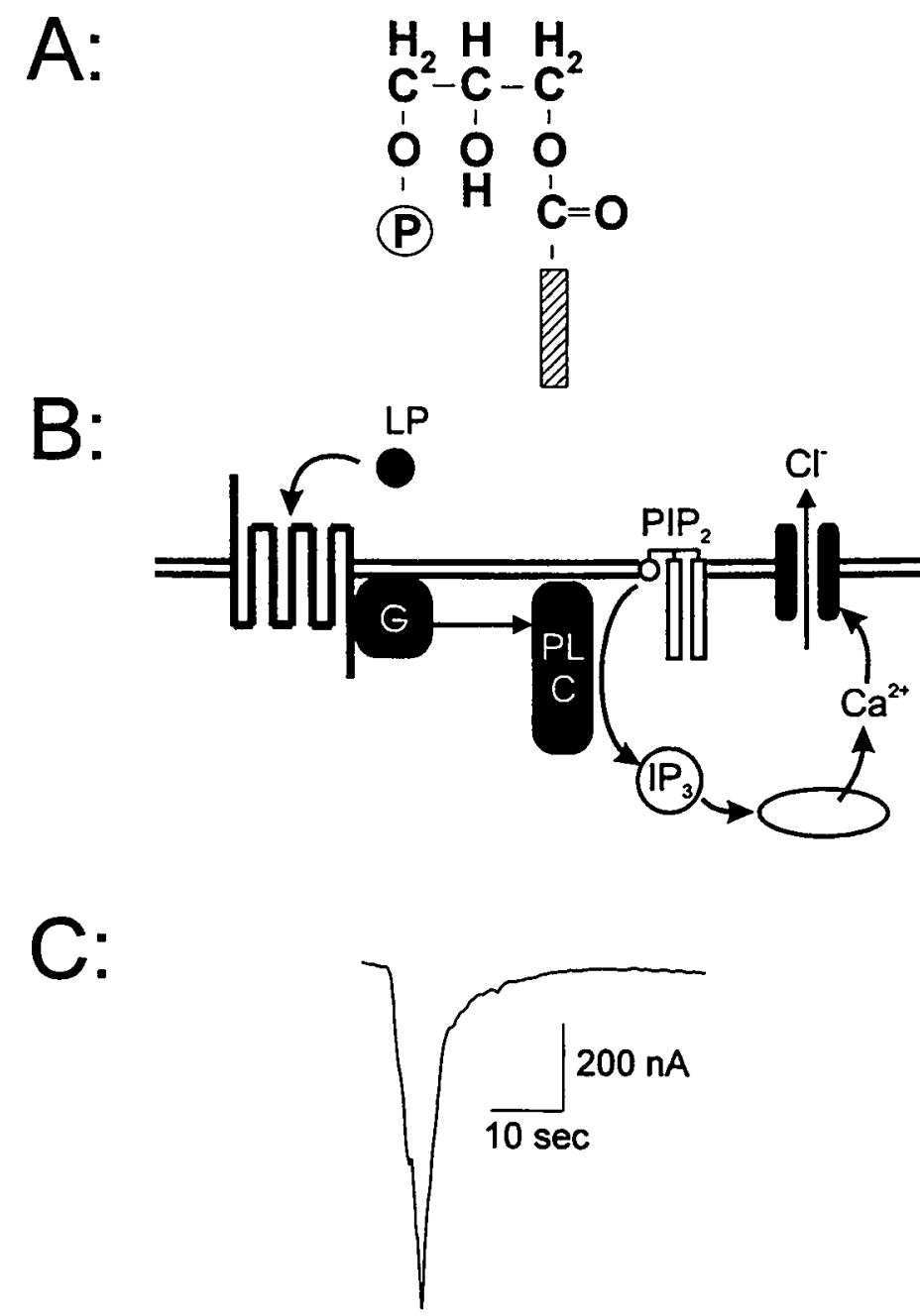

Figure 1. Lysophosphatidate (LP) structure and signaling in Xenopus oocytes. A: Structure of LP. The circled "P" represents a phosphate group. The striped rectangle represents an acyl chain (18:1 in the present study). B: Signaling pathway linking stimulation of the endogenous LP receptor in Xenopus oocytes to $\mathrm{Cl}^{-}$channel opening. The double line represents the cell membrane. The agonist LP binds to its receptor and the resulting signal is transduced via the coupled $G$ protein (G) to phospholipase $C$ (PLC). PLC produces the second messenger inositoltriphosphate $\left(\mathrm{IP}_{3}\right)$ from phosphatidylinositolbiphosphate $(\mathrm{PIP})$. Calcium $\left(\mathrm{Ca}^{2+)}\right.$ released from intracellular stores by $\mathrm{IP}_{3}$ then activates calcium-dependent chloride channels in the cell membrane. The resulting $\mathrm{Cl}^{-}$flux $\left(\mathrm{I}_{\mathrm{Cl}\left(\mathrm{C}_{2}\right)}\right)$ is a measure of intracellular $\mathrm{Ca}^{2+}$ release. $C$ : Example of inward $\mathrm{Cl}^{-}$current induced by $10^{-7} \mathrm{M} \mathrm{LP}$ in a defolliculated oocyte. Holding potential was $-70 \mathrm{mV}$. Charge movement was $3.6 \mu \mathrm{C}$. 

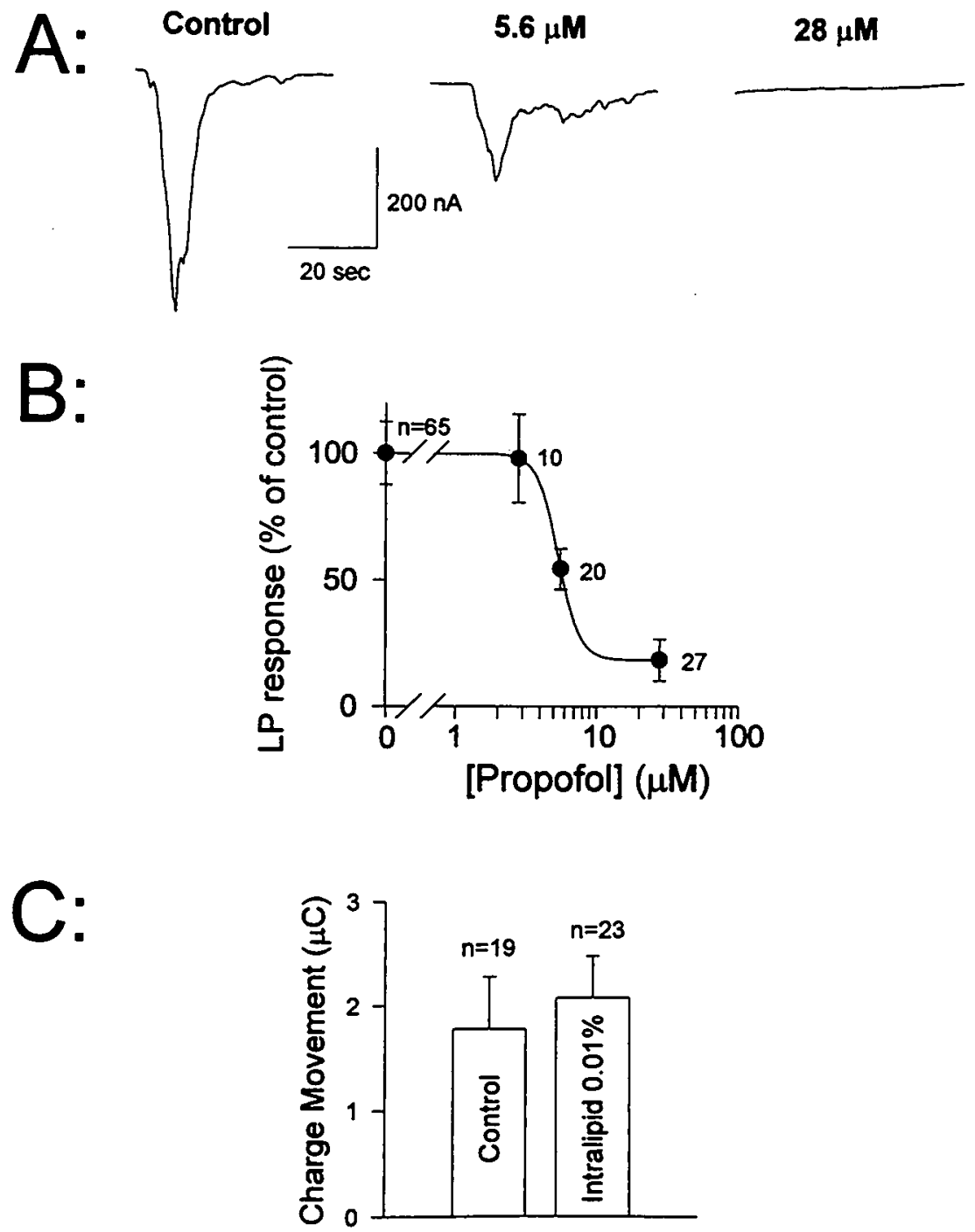

Figure 2. Propofol inhibits lysophosphatidate (LP) signaling in oocytes. All oocytes are voltage clamped at a holding potential of $-70 \mathrm{mV}$. A. Examples of $\mathrm{I}_{\mathrm{CI}(\mathrm{Ca})}$ induced by $\mathrm{LP}$ alone $(3.1 \mu \mathrm{C})$ and in the presence of 5.6 and $28 \mu \mathrm{M}$ propofol $(1.7$ and $0 \mu \mathrm{C}$, respectively). $B$ : Propofol has a dose-dependent inhibitory effect on $\mathrm{I}_{\mathrm{Cl}_{\left(C_{2}\right)}}$ induced by $10^{-7} \mathrm{M} \mathrm{LP}$ in uninjected oocytes. The number of oocytes used for each data point is indicated. The $50 \%$ inhibitory concentration is $5.38 \mu \mathrm{M}$; maximum depression is $81 \%$. C: Responses to $10^{-7} \mathrm{M} \mathrm{LP}$ in control oocytes, and those exposed to $0.01 \%$ Intralipid ${ }^{\otimes}$. Intralipid ${ }^{\circledast}$ does $^{\circ}$ not affect LP signaling. 


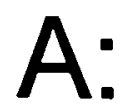

Control

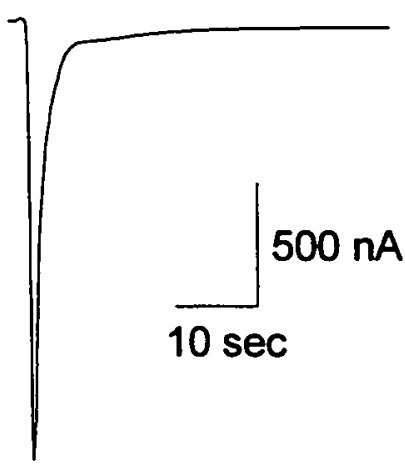

5.6 $\mu \mathrm{M}$ Propofol

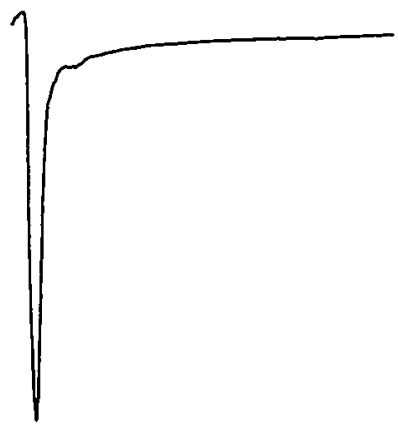

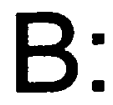

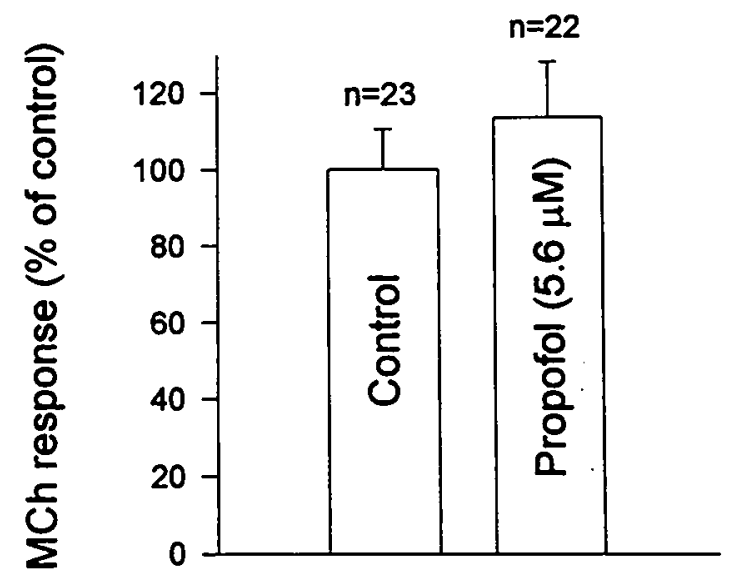

Figure 3. Propofol $(5.6 \mu \mathrm{M})$ does not inhibit $\mathrm{ml}$ muscarinic signaling in oocytes. All oocytes are voltage clamped at a holding potential of $-70 \mathrm{mV}$. $A$ : Methylcholine $\left(\mathrm{MCh} ; 10^{-7} \mathrm{M}\right)$ applied to defolliculated oocytes 3 days after injection with $3.5 \mathrm{ng} \mathrm{ml} \mathrm{receptor} \mathrm{mRNA,} \mathrm{one} \mathrm{incubated} \mathrm{for} 1 \mathrm{~min}$ in $5.6 \mu \mathrm{M}$ propofol, and one control oocyte from the same frog (each response is $3.2 \mu \mathrm{C}$ ). B: Responses to $10^{-7} \mathrm{M}$ $\mathrm{MCh}$ in control oocytes and those exposed to $5.6 \mu \mathrm{M}$ propofol. $\mathrm{n}=$ number oocytes in each group. 


\section{PROPOFOL AND LYSOPHOSPHATIDATE SIGNALING}

\section{Effects of propofol on ml signaling}

To ascertain that the effect of propofol on LP signaling was not due to interference with intracellular pathways or the $\mathrm{Cl}^{-}$channel, we expressed the $\mathrm{ml}$ muscarinic acetylcholine receptor in Xenopus oocytes. Like the LP receptor, the ml receptor is a member of the G protein-coupled receptor superfamily. When expressed in oocytes it also induces $\mathrm{I}_{\mathrm{Cl}(\mathrm{Ca})}$ through a mechanism that, apart from receptor and possibly G protein, is considered to be the same as that for LP signaling. Lack of propofol inhibition of muscarinic signaling would therefore make an effect on the signaling pathway downstream of the LP receptor unlikely.

Methylcholine $10^{-7} \mathrm{M}$, a nonhydrolyzable agonist at the ml muscarinic acetylcholine receptor, was without effect on uninjected oocytes (data not shown), but induced $\mathrm{I}_{\mathrm{Cl}(\mathrm{Ca})}$ in oocytes expressing the $\mathrm{ml}$ receptor. These currents had a somewhat shorter latency and larger peaks than did LP-induced currents, but were otherwise similar (Figure 3A). Average charge movement was $5.8 \pm 0.7 \mu \mathrm{C}(n=52)$. Presence of $5.6 \mu \mathrm{M}$ propofol (close to the $\mathrm{IC}_{50}$ for LP inhibition, $5.4 \mu \mathrm{M}$ ) did not interfere with muscarinic signaling (Figure $3 \mathrm{~B}$ ). Therefore, inhibition of LP signaling by this concentration of propofol is unlikely to be explained by effects on intracellular pathways or the $\mathrm{Ca}^{2+}$-activated $\mathrm{Cl}^{-}$channel of the oocyte.

\section{DISCUSSION}

The main finding of our study is that propofol, in clinical concentrations, profoundly inhibits LP-induced $\mathrm{I}_{\mathrm{Cl}\left(\mathrm{C}_{a}\right)}$ in Xenopus oocytes. The vehicle Intralipid ${ }^{\circledR}$ was without effect. Propofol concentrations that depressed LP signaling by $50 \%$ were without effect on $\mathrm{I}_{\mathrm{Cl}(\mathrm{Ca})}$ induced by methylcholine in oocytes expressing the ml muscarinic receptor.

This latter finding suggests strongly that propofol's site of action on LP signaling is the LP receptor and not a site downstream in the signaling pathway. In the Xenopus oocyte only a single isoform of phospholipase $\mathrm{C}$ couples receptor activation to $\mathrm{Ca}^{2+}$ release. ${ }^{\text {" }}$ Therefore, both $\mathrm{LP}$ and $\mathrm{ml}$ receptors couple to this isoform, and the signaling pathway downstream from this point (including the intracellular $\mathrm{Ca}^{2+}$ release mechanism and the $\mathrm{Ca}^{2+}$-activated $\mathrm{Cl}^{-}$channel) will be the same for both receptors. The comparable kinetics of the responses supports this (the slightly slower responses to LP presumably being due to its poor water solubility and its binding to albumin). As $5.6 \mu \mathrm{M}$ propofol was without effect on ml signaling, it is unlikely that its inhibitory action on LP signaling takes place downstream of the LP receptor or the associated G protein. One issue that deserves further study is the interaction between propofol and LP bound to the physiologic carrier protein, albumin.

Several potential limitations of our model system should be considered. First, we performed our experiments at room temperature, and interactions between propofol and LP receptors might be different in homeothermic animals at higher temperatures. In addition, lack of propofol effect on muscarinic signaling might in theory be due to disturbed functioning of the (rat) receptor clone at low temperatures. However, this is unlikely as we have shown previously that halothane $e^{12}$ and ketamine ${ }^{13}$ inhibit muscarinic signaling in this model in a manner comparable with that found in other systems. Thus, although it cannot be ruled out that temperature might affect protein functioning to some degree, we thought it more important to maintain the cell membrane in its normal state of fluidity. A second potential issue with our choice of model is that the Xenopus LP receptor might be of a different type, potentially with a different response to 


\section{CHAPTER 9}

propofol, than its mammalian homolog. As the LP receptor has not yet been cloned, no molecular biological evidence exists for multiple receptor subtypes. Similarly, no published pharmacological or functional studies suggest the existence of different receptor subtypes. Indeed, LP signaling in oocytes has been shown to be quite comparable to that in other cell types. Therefore, the flexibility of the oocyte model far outweighs the remote possibility of a different propofol effect in another model. Thirdly, endogenous muscarinic receptors have been reported in Xenopus oocytes. ${ }^{14}$ However, we have not observed these in this or our previous studies; $;^{9,12,13}$ apparently many frogs do not express such receptors.

Although it is well established that propofol's primary site of action is on the $\mathrm{GABA}_{\mathrm{A}}$ receptor/ $\mathrm{Cl}^{-}$channel, ${ }^{1-3}$ this does not rule out other interactions. In fact, several other activities of the compound have been described. Propofol affects another ligand-gated ion channel, the nicotinic acetylcholine receptor. In a concentration of $15 \mu \mathrm{M}$ it decreased channel open time without affecting single channel conductance. ${ }^{15}$ Effects on voltage-activated channels have also been reported. For example, propofol at concentrations between 30 and $150 \mu \mathrm{M}$ reduced sodium channel fractional open time and interfered with voltage-dependent steady state activation. ${ }^{16}$ Similarly, $\mathrm{K}^{+}$currents in PCl2 cells were inhibited by propofol ( $50 \mu \mathrm{M}$ to $\left.1 \mathrm{mM}\right),{ }^{17}$ and $300 \mu \mathrm{M}$ propofol inhibited $\mathrm{Ca}^{2+}$ currents in chick sensory neurons. ${ }^{18}$ However, the compound also has effects on second messenger-mediated systems. In concentrations ranging from 0.17 to $280 \mu \mathrm{M}$ it induced release of intracellular $\mathrm{Ca}^{2+}$ in embryonic rat brain cells (but propofol did not induce $\mathrm{I}_{\mathrm{CI}(\mathrm{Ca})}$ in our model) and reorganization of the actin cytoskeleton in human astrocytes. ${ }^{19}$ It also activated protein kinase $C$ with an $50 \%$ effective concentration of $240 \mu \mathrm{M}^{20}$ The latter finding is of particular interest in the current context, as protein kinase $C$ is physiologically activated by a lipid agonist, diacylglycerol.

One issue of importance in interpreting such studies is the concentration of propofol used. It is quite difficult to determine the relevant concentration at the site of action for a drug as lipophilic as propofol, that in addition is very highly protein-bound ( $>95 \%)$. The minimally effective propofol plasma concentration for general anesthesia is considered to be around $1 \mu \mathrm{g} / \mathrm{mL}$, or approximately $5 \mu \mathrm{M}^{21}$ Free concentrations would of course be considerably smaller, but on the other hand enrichment might take place at the (lipophilic) site of action. We think that studies demonstrating effects of propofol at concentrations larger than $50 \mu \mathrm{M}$ should be interpreted cautiously. The $\mathrm{IC}_{50}$ observed in the present study, $5.4 \mu \mathrm{M}$, is certainly within the clinically relevant range.

Although outside the scope of the study, it is interesting to speculate whether inhibition of LP signaling might explain some of propofol's side effects. LP has a wide variety of actions in several systems. Best described are its mitogenic, ${ }^{22,23}$ platelet aggregating, ${ }^{24}$ and smooth muscle contractile effects. ${ }^{25}$ In addition, it induces actin stress fiber rearrangement and resulting cellular shape changes. ${ }^{26}$ Its physiologic or pathophysiologic role is unknown, although a function in the vasculature seems likely. Supporting this hypothesis are findings that activated platelets form the primary source of $\mathrm{LP},{ }^{27}$ that LP is a vasoconstrictor, ${ }^{28}$ and that the compound induces mitosis in vascular smooth muscle cells. ${ }^{23}$ If LP does play a role in the maintenance of vascular tone, inhibition of LP signaling might explain some of the vasodilatory actions of propofol. However, this hypothesis will require additional study.

In summary, we have demonstrated that clinically relevant concentrations of propofol significantly inhibit LP signaling, an effect most likely taking place at the LP receptor or its associated $G$ protein. Our findings imply that, at the concentrations used during general anesthe- 


\section{PROPOFOL AND LYSOPHOSPHATIDATE SIGNALING}

sia, propofol has more than a single site of action. Therefore, study of interactions between propofol and other lipid mediator receptors (such as those for the prostaglandins) are indicated.

\section{REFERENCES}

1. Concas A, Santoro G, Mascia MP, et al: The general anesthetic propofol enhances the function of gamma-aminobutyric acid-coupled chloride channel in the rat cerebral cortex. $J$ Neurochem 1990; $55: 2135-8$

2. Concas A, Santoro G, Serra M, et al: Neurochemical action of the general anesthetic propofol on the chloride channel coupled with GABA $_{A}$ receptors. Brain Res 1991; 542: 225-32.

3. Hales TG, Lambert JJ: The actions of propofol on inhibitory amino acid receptors of bovine adrenomedullary chromaffin cells and rodent central neurones. Br J Pharmacol 1991;104: 619-28.

4. Mouren S, Baron JF, Albo C, et al: Effects of propofol and thiopental on coronary blood flow and myocardial performance in an isolated rabbit heart. Anesthesiology 1994; 80: 634-41

5. Moolenaar WH: LPA: a novel lipid mediator with diverse biological actions. Trends Cell Biol 1994; 4: 213-9.

6. Durieux ME, Lynch KR: Signalling properties of lysophosphatidic acid. Trends Pharmacol Sci 1993; 14: 249-54

7. Durieux ME, Carlisle SJ, Salafranca MN, Lynch KR: Endogenous responses to sphingosine-1-phosphate in $X$. laevis oocytes: similarities with lysophosphatidic acid signaling. Am J Physiol 1993; 264: C1360-4

8. Durieux ME: Lysophosphatidate signaling: cellular effects and molecular mechanisms. New York: Springer-Verlag/R. G. Landes Company, 1995.

9. Durieux ME, Salafranca MN, Lynch KR, Moorman JR: Lysophosphatidic acid induces a pertussis toxin-sensitive $\mathrm{Ca}^{2+}$-activated $\mathrm{Cl}^{-}$current in Xenopus laevis oocytes. Am J Physiol 1992; 263: C896-900

10. Durieux ME: OoClamp: an IBM-compatible software system for the study of receptors expressed in Xenopus oocytes. Comp Meth Prog Biomed 1993; 41: 101-5

11. $\mathrm{Ma} \mathrm{H}$, Blitzer RD, Healy EC, et al: Receptor-evoked $\mathrm{Cl}^{-}$current in Xenopus oocytes is mediated through a $\beta$-type phospholipase $C$; cloning a new form of the enzyme. $J$ Biol Chem 1993; 268: 19915-8

12. Durieux ME: Halothane inhibits signaling through $\mathrm{ml}$ muscarinic receptors expressed in Xenopus oocytes. Anesthesiology 1995; 82: 174-82

13. Durieux ME: Inhibition by ketamine of muscarinic acetylcholine receptor function. Anesth Analg 1995; 81: 57-62

14. Dascal N, Landau EM: Types of muscarinic receptors in Xenopus oocytes. Life Sci 1980; 27: 1423-8

15. Wachtel RE, Wegrzynowicz ES: Kinetics of nicotinic acetylcholine ion channels in the presence of intravenous anesthetics and induction agents. Br J Pharmacol 1992; 106: 623-7

16. Frenkel C, Urban BW: Human brain sodium channels as one of the molecular target sites for the new intravenous anesthetic propofol (2,6-diisopropylphenol). Eur J Pharmacol 1991; 208: 75-9

17. Magnelli V, Nobile M, Maestrone $\mathrm{E}: \mathrm{K}^{+}$channels in PC12 cells are affected by propofol. Pflügers Arch 1992; 420: 393-8 


\section{CHAPTER 9}

18. Olcese R, Usai C, Maestrone E, Nobile M: The general anesthetic propofol inhibits transmembrane calcium currents in chick sensory neurons. Anesth Analg 1994; 78: 955-60

19. Jensen $A G$, Lindroth $M$, Sjolander A, Eintrei $C$ : Propofol induces changes in cytosolic free calcium concentration and the cytoskeletal organization of cultured human glial cells and primary embryonic rat brain cells. Anesthesiology 1994; 81: 1220-9

20. Hemmings HC, Adamo AI: Effects of halothane and propofol on purified brain protein kinase $C$ activation. Anesthesiology 1994; 81: 147-55

21. Shafer A, Doze VA, Shafer S, White PF: Pharmacokinetics and pharmacodynamics of propofol infusions during general anesthesia. Anesthesiology 1988; 69: 348-56

22. van Corven EJ, Groenink A, Jalink K, et al. Lysophosphatidate-induced cell proliferation: identification and dissection of signaling pathways mediated by $\mathrm{G}$ proteins. Cell 1989; 59: 45-54

23. Tokumura $A$, Iimori $M$, Nishioka $Y$, et al: Lysophosphatidic acids induce proliferation of cultured vascular smooth muscle cells from rat aorta. Am J Physiol 1994; 267: C204-10

24. Schumacher KA, Classen HG, Späth M: Platelet aggregation evoked in vitro and in vivo by phosphatidic acids and lysoderivatives: identity with substances in aged serum (DAS). Thromb Haemost 1979; 42: 631-40

25. Tokumura A, Fukuzawa K, Yamada S: Stimulatory effect of lysophosphatidic acids on uterine smooth muscles of nonpregnant rats. Arch Int Pharmadyn Ther 1980; 245: 74-83

26. Ridley AJ, Hall A. The small GTP-binding protein tho regulates the assembly of focal adhesions and actin stress fibers in response to growth factors. Cell 1992; 70: 389-99

27. Eichholtz T, Jalink K, Fahrenfort I, Moolenaar WH: The bioactive phospholipid lysophosphatidic acid is released from activated platelets. Biochem J 1993; 291: 677-80

28. Tigyi $G$, Hong L, Yakubu M, et al: Lysophosphatidic acid alters cerebrovascular reactivity in piglets. Am J Physiol 1995; 268: H2048-55 
CHAPTER 10

Differential inhibition of lysophosphatidate signaling by volatile anesthetics

Carrie K. Chan

Marcel E. Durieux

Anesthesiology 1997; 80: 600-609

Reproduced with permission from the publisher. 


\title{
Differential Inhibition of Lysophosphatidate Signaling by Volatile Anesthetics
}

\begin{abstract}
Background: Volatile anesthetics have been found to interfere with the functioning of several $G$ protein-coupled receptors, effects that may be relevant to the mechanism of anesthetic action. Lysophosphatidate (1-acyl-2-sn-glycero-3-phosphate; LP) is the simplest natural phospholipid. It has pronounced biological effects and signals through a specific $G$ protein-coupled receptor. Because of its lipophilicity, the LP receptor is a feasible site of anesthetic interaction. Therefore, the authors investigated the effects of halothane and isoflurane on LP signaling using Xenopus oocytes.

Methods: Mature oocytes were harvested from Xenopus frogs, isolated, and defolliculated manually. Lysophosphatidate receptors are endogenously present in these cells. Angiotensin receptors were expressed recombinantly to study anesthetic effects on intracellular signaling. Oocytes were studied individually with a two-electrode voltage clamp at room temperature. Integrated $\mathrm{Ca}^{2+}$-activated $\mathrm{Cl}^{-}$currents $\left(\mathrm{I}_{\mathrm{Cl}\left(\mathrm{C}_{a}\right)}\right)$ were used to evaluate the effects of anesthetics on changes in intracellular $\mathrm{Ca}^{2+}$ concentration in response to receptor agonists $\left(10^{-7} \mathrm{M} \mathrm{LP}\right.$ or $10^{-7} \mathrm{M}$ angiotensin II) or intracellular inositoltrisphosphate $\left(\mathrm{IP}_{3}\right)$ injection.

Results: Halothane depressed LP signaling in a concentration-dependent manner, with half-maximal inhibition at $0.23 \mathrm{mM}$ and virtually complete inhibition at $0.34 \mathrm{mM}$. Responses could be recovered after an anesthetic-free wash. Oocyte injection with heparin, an $\mathbb{P}_{3}$ receptor antagonist, completely blocked LP and angiotensin signaling, indicating similar $\mathrm{IP}_{3}$ dependent pathways. However, $\mathrm{I}_{\mathrm{Cl}(\mathrm{Ca})}$ induced by angiotensin receptor activation or intracellular $\mathrm{IP}_{3}$ injection were not inhibited by halothane. Isoflurane, at comparable concentrations, did not depress LP responses in oocytes significantly.

Conclusions: Lipid mediator signaling can be affected profoundly by volatile anesthetics. At clinically relevant concentrations, halothane and isoflurane have different effects on LP signalng. The inhibitory effects of halothane on the LP signaling pathway occur before the $\mathrm{IP}_{3}$ receptor.
\end{abstract}

Key words: Anesthetics, volatile: halothane; isoflurane. Receptors: angiotensin; G protein-coupled; lysophosphatidate. Xenopus laevis oocytes.

\section{INTRODUCTION}

Volatile anesthetics interact with various cellular systems, although the relative importance of these interactions to clinical anesthesia is largely unknown. Much recent research has focused on anesthetic-protein interactions. Effects on N-methyl-D-aspartate, ${ }^{1-3}$ and gamma amino-butyric acid receptor ${ }^{2,4,5}$ signaling seem to offer the most promise for explaining the mechanism of general anesthesia. However, interactions with other systems may also be important, either in modulatory roles or by inducing anesthetic side effects.

Although anesthetic interactions with ion channel function have been studied in some detail, effects on second messenger-linked receptors have been investigated to a limited extent only. Nonetheless, studies have shown pronounced inhibition of, for example, muscarinic acetyl- 
choline ${ }^{6-9}$ and serotonin ${ }^{9-11}$ receptor functioning, making the interactions between anesthetics and $G$ protein-coupled receptors a worthwhile field of investigation. Of specific relevance are receptors for lipid mediators, because a hydrophobic ligand-binding domain might be a likely site of anesthetic action. The field of lipid mediators has attracted much attention recently and includes important messengers such as the prostaglandins and platelet-activating factor.

Lysophosphatidate (1-acyl-2-hydroxy-sn-glycero-3-phosphate; LP) is a novel lipid mediator, ${ }^{12,13}$ originally known only as a precursor in de novo lipid synthesis. ${ }^{14}$ However, LP also has several pronounced biological effects, including the induction of smooth muscle contraction, ${ }_{15-17}$ cellular proliferation, ${ }^{18-20}$ and platelet aggregation. ${ }^{21-23}$ Many of these effects may be due to LP's pronounced ability to induce actin stress fiber reorganization, and they are mediated through a specific $G$ protein-coupled receptor for the compound. ${ }^{24}$ Although some volatile anesthetics exhibit effects opposite to those of LP signaling in various cell types, suggesting an interaction, and although the lipophilicity of LP makes its receptor a feasible site for such interaction, the direct anesthetic effects on the LP signaling system have not been studied.

We hypothesized that LP signaling can be inhibited by volatile anesthetics. To test this hypothesis, we studied the effects of halothane and isoflurane on LP signaling in Xenopus laevis oocytes. Xenopus oocytes form a good model to study the compound because these cell express a well-described endogenous LP signaling system ${ }^{25-28}$ coupled to intracellular $\mathrm{Ca}^{2+}$ release (Figure 1A). In addition, the presence of $\mathrm{Ca}^{2+}$-activated $\mathrm{Cl}^{-}$channels allows convenient measurement of this $\mathrm{Ca}^{2+}$ release by electrophysiologic means. ${ }^{26-29}$ In this study, we tried to answer the following questions:

1. Do volatile anesthetics, at clinically relevant concentrations, affect LP signaling in oocytes?

2. If so, are there differences in effect between halothane and isoflurane, two anesthetics used frequently in clinical practice?

3. Can these effects be localized to a specific segment of the signaling pathway?

\section{MATERIALS AND METHODS}

\section{Animals}

The study protocol was approved by the Animal Research Committee at the University of Virginia. Female Xenopus laevis frogs were obtained from Xenopus I (Ann Arbor, MI), housed in an established frog colony, and fed regular frog brittle twice per week. To remove the oocytes, each frog was anesthetized by immersion in $0.2 \%$ methanesulfonate salt solution until unresponsive to a painful stimulus (toe pinching). A $1-\mathrm{cm}-$ long incision was made in a lower abdominal quadrant and a lobule of ovarian tissue, containing approximately 200 oocytes, was removed and placed in modified Barth's solution $\left(88 \mathrm{mM} \mathrm{NaCl}, 1 \mathrm{mM} \mathrm{KCl}, 2.4 \mathrm{mM} \mathrm{NaHCO}{ }_{3}\right.$, $0.41 \mathrm{mM} \mathrm{CaCl} 2,0.82 \mathrm{mM} \mathrm{MgSO}_{4}, 0.3 \mathrm{mM} \mathrm{Ca}_{2} \mathrm{NO}_{3} 15 \mathrm{mM} \mathrm{HEPES}$, and $0.1 \mathrm{mg} / \mathrm{ml}$ gentamicin, $\mathrm{pH}$ adjusted to 7.4). The wound was closed in two layers and the frog was allowed to recover from anesthesia, kept in a separate tank overnight, and returned to the colony the next day.

The ovarian tissue was immediately and copiously washed in modified Barth's solution and dissected into small clusters of 20 to 50 oocytes. Mature oocytes (Dumont stages V and VI) were isolated, defolliculated manually with microforceps, and maintained in modified Barth's solution. 


\section{Materials}

Lysophosphatidate (1-oleoyl-2-hydroxy-sn-glycero-3-phosphate) stock was obtained from Avanti Polar Lipids (Alabaster, AL) and diluted in a $1 \%$ solution of fatty acid-free bovine serum albumin (BSA; ICN Pharmaccuticals, Costa Mesa, CA) to appropriate concentrations. Halothane and isoflurane were obtained from Halocarbon Laboratories (River Edge, NJ) and Ohmeda PPD (Liberty Comer, NJ), respectively. All other chemicals were obtained from Sigma Chemical Company (St. Louis, MO).

\section{Electrophysiologic recording}

A single defolliculated oocyte was placed in a perfusable recording chamber (3-ml volume) filled with Tyrode's solution (150 $\mathrm{mM} \mathrm{NaCl}, 5 \mathrm{mM} \mathrm{KCl}, 1 \mathrm{mM} \mathrm{MgCl}, 2.2 \mathrm{mM} \mathrm{CaCl}, 10$ $\mathrm{mM}$ dextrose, $10 \mathrm{mM}$ HEPES, $p \mathrm{H}$ adjusted to 7.4). Microelectrodes were pulled in one stage from capillary glass (BBL with fiber; World Precision Instruments, Sarasota, FL) on a micropipette puller (model 700C; David Kopf Instruments, Tujunga, CA). Electrode tips were broken to a diameter of approximately $10 \mu \mathrm{m}$, providing a resistance of 1 to $3 \mathrm{M} \Omega$, and filled with $3 \mathrm{M}$ $\mathrm{KCl}$. The cell was voltage clamped using a two-microelectrode oocyte voltage-clamp amplifier (OC725A; Warner Corp., New Haven, CT) connected to a data acquisition and analysis system running on an IBM-compatible personal computer. The acquisition system consisted of a DAS-8 A/D conversion board (Keithley-Metrabyte, Taunton, MA), and analysis was performed with OoClamp software. ${ }^{30}$ Holding potential was $-70 \mathrm{mV}$, and only cells exhibiting stable holding currents less than $1 \mu \mathrm{A}$ during a 1 -min equilibration period were included in analysis. Membrane current was sampled at $125 \mathrm{~Hz}$ and recorded for $5 \mathrm{~s}$ before and $55 \mathrm{~s}$ after application of the appropriate receptor agonist. Agonists were delivered in 30- $\mu$ l aliquots for a period of 1 to $2 \mathrm{~s}$ using a hand-held micropipettor positioned approximately $5 \mathrm{~mm}$ from the oocyte. Unless otherwise indicated, washout did not occur during the time scale of traces presented. To prevent desensitization of the receptor or signaling pathways from influencing the results, each oocyte received only a single agonist application. Responses were quantified by integrating the current trace by quadrature and are reported in microcoulombs $(\mu \mathrm{C})$. All experiments were performed at room temperature.

\section{Anesthetic administration}

To determine the effects of halothane and isoflurane on LP-induced currents, output from the appropriate vaporizer was bubbled through a reservoir filled with $30 \mathrm{ml}$ Tyrode's solution and allowed to equilibrate for at least $10 \mathrm{~min}$. Air at a flow rate of $500 \mathrm{ml} / \mathrm{min}$ was used as the carrier gas. After equilibration, the solution from the reservoir was perfused through the recording chamber at a rate of approximately $10 \mathrm{ml} / \mathrm{min}$, and measurements were obtained after ten bath volumes had been exchanged $(3 \mathrm{~min}$ ). The concentrations of the anesthetics in the recording chamber were quantified by gas chromatography: Triplicate samples from the recording chamber were equilibrated with air and analyzed in a gas chromatograph (Aerograph 940; Varian Analytical Instruments, Walnut Creek, CA) calibrated with the appropriate standard. Results were converted to concentrations in liquid using Kreb's solution/ air partition coefficients at $25^{\circ} \mathrm{C}^{31}$ and to 
corresponding partial pressure (vol\%) at that temperature. ${ }^{32}$ Each oocyte was exposed to a single concentration of anesthetic only.

\section{Intracellular injection}

To study inositoltrisphosphate $\left(\mathrm{IP}_{3}\right)$-induced $\mathrm{Ca}^{2+}$-activated $\mathrm{Cl}^{-}$currents $\left(\mathrm{I}_{\mathrm{Cl}(\mathrm{Ca})}\right)$ a third microelectrode, connected to an automated microinjector (Nanoject; Drummond Scientific, Broomall, PA), was inserted into the oocyte under voltage clamp. Oocytes were injected with 50 $\mathrm{nl} \mathrm{IP}_{3}$ (final concentration $100 \mu \mathrm{M}$ ) and adequacy of injection was confirmed by noting a small increase in cell size. Membrane currents were recorded for $5 \mathrm{~s}$ before and $55 \mathrm{~s}$ after $\mathbb{I P}_{3}$ injection. Microinjection pipettes were examined for obstruction before and after recording. Only experiments in which tips were fully functional before and after injection were included in the analysis.

For intracellular injection of heparin, an automated microinjector (Nanoject) was used. Oocytes were injected with $60 \mathrm{nl}$ heparin (final concentration $120 \mathrm{ng} / \mu \mathrm{l}$ ) at least $30 \mathrm{~min}$ before agonist application. Adequacy of injection was confirmed by observing the small increase in cell size on injection.

\section{$c R N A$ synthesis and injection}

The rat $\mathrm{AT}_{1 \mathrm{~A}}$ angiotensin II receptor clone was obtained from Dr. K. R. Lynch (University of Virginia, Chariottesville, VA) as a cDNA of 1.2 kilobasepair in the CDM8 vector (Invitrogen, San Diego, CA). The construct was linearized with the nuclease $X$ ho $I$ and transcribed in the presence of a capping analog by $T 7$ polymerase.

Oocytes were injected with $50 \mathrm{nl}$ cRNA (3-5 ng) in water using an automated microinjector (Nanoject). The adequacy of injection was confirmed by noting the slight increase in cell size during injection. The cells were cultured in modified Barth's solution for 3 days before study.

\section{Data analysis}

Responses are reported as means \pm SEM. Differences among treatment groups were analyzed using Student's $t$ test. If multiple comparisons were made, data were analyzed using analysis of variance followed by a $t$ test corrected for multiple comparisons. Probability values less than 0.05 were considered significant. Concentration-response curves were fit to the following logistic function, derived from the Hill equation:

$$
y=y_{\min }+\left(y_{\max }-y_{\min }\right)\left(1-\frac{x^{n}}{x_{50}^{n}+x^{n}}\right)
$$

where $y_{\max }$ and $y_{\min }$ are the maximum and minimum obtained response, $n$ is the Hill coefficient, and $x_{50}$ is the concentration at which the half-maximal response occurs. 

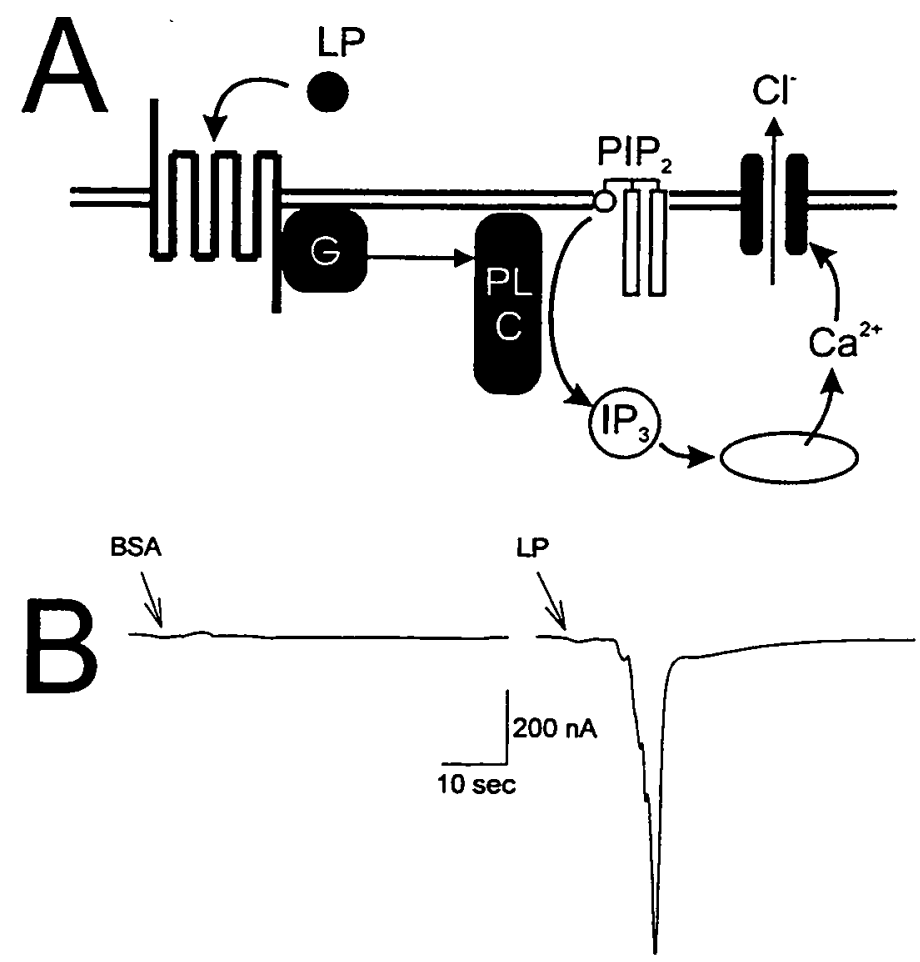

Figure 1. Endogenous tysophosphatidate (LP) signaling in Xenopus oocytes. A: The signaling pathway linking LP receptor activation to chloride $\left(\mathrm{Cl}^{-}\right)$channel opening. The double line represents the cell membrane. The agonist $L P$ binds to its receptor, which transduces the signal via the coupled $G$ protein (G) to phospholipase C (PLC), which produces the second messenger inositoltrisphosphate $\left(\mathrm{IP}_{3}\right)$ from phosphatidylinositolbisphosphate $\left(\mathrm{PIP}_{2}\right)$. Calcium $\left(\mathrm{Ca}^{2+}\right)$, released from $\mathrm{PP}_{3}$-sensitive intracellular stores, then activates $\mathrm{Ca}^{2+}$-dependent $\mathrm{Cl}^{-}$channels in the cell membrane. The resulting $\mathrm{Cl}^{-}$current $\left(I_{\left.C_{(1} C_{2}\right)}\right)$ is integrated and expressed in microcoulombs $\left(\mu \mathrm{C}\right.$; charge movement). $B$ : Inward $\mathrm{Cl}^{-}$current induced by $10^{-7} \mu \mathrm{M}$ LP (second trace) but not by $1 \%$ bovine serum albumin (first trace) in the same defolliculated oocyte. The charge movement in response to $\mathrm{LP}$ is $2.9 \mu \mathrm{C}$.

\section{RESULTS}

\section{Lysophosphatidate induces an imward current in oocytes}

Whereas application of $1 \%$ BSA had no effect on oocytes at a holding potential of -70 $\mathrm{mV}$ (Figure 1B), application of $10^{-7} \mathrm{M} \mathrm{LP}$ (approximately the median effective concentration in this model $^{33}$ ), diluted in $1 \%$ BSA, resulted in transient inward currents of several microamperes. The current developed after a short latency period $(\sim 5 s)$ and consisted of a fast inward component followed by a relaxation over several seconds with superimposed small fluctuations. We and others have shown previously that the oocyte responses to LP are due to release of $\mathrm{Ca}^{2+}$ from 
[HAL]: $\quad 0 \mathrm{mM} \quad 0.22 \mathrm{mM} \quad 0.34 \mathrm{mM}$
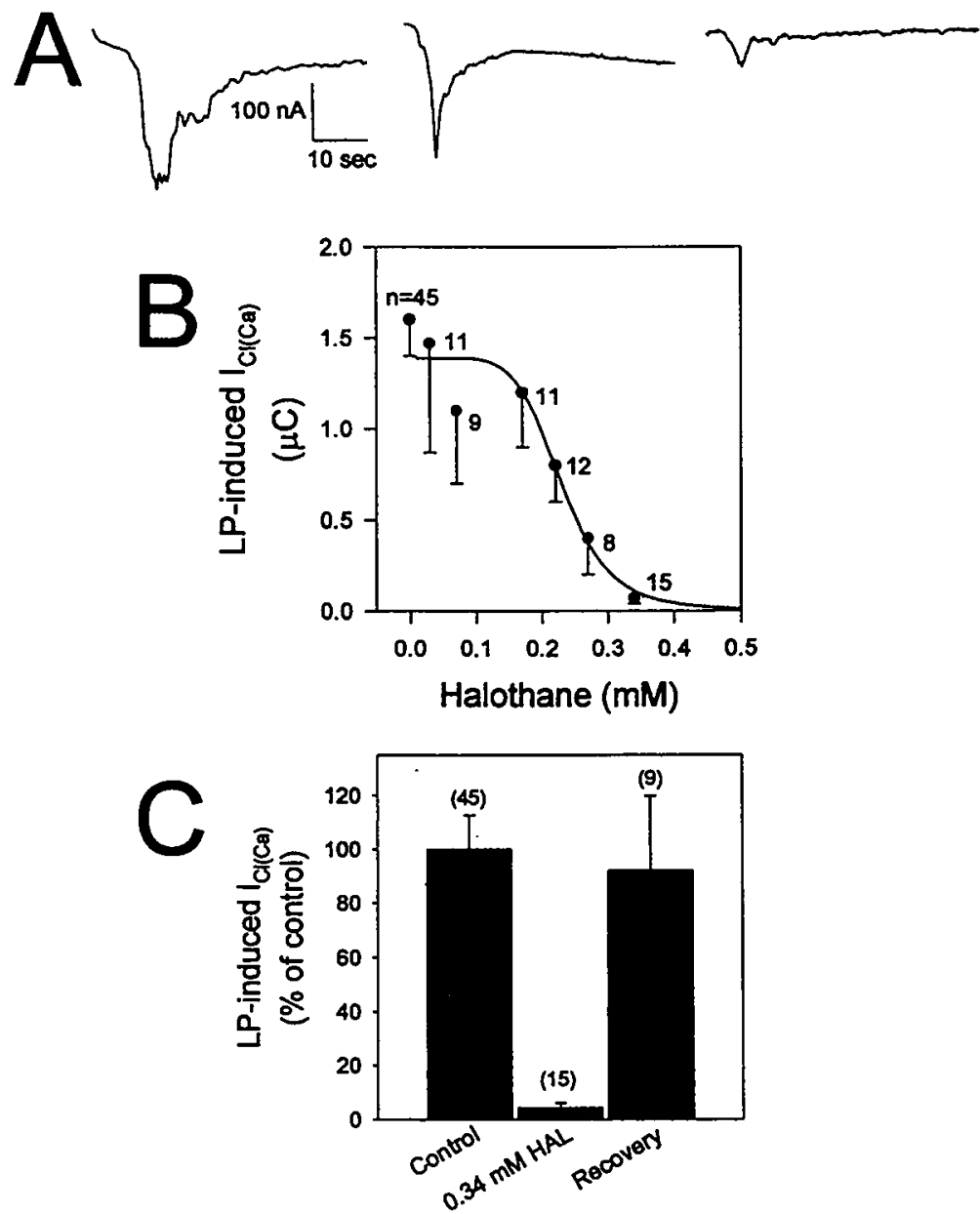

Figure 2. Halothane inhibits lysophosphatidate (LP) signaling in oocytes. A: Sample traces of LP-induced $\mathrm{I}_{\mathrm{Cl}\left(\mathrm{C}_{3}\right)}$ in the absence and presence of halothane. Charge movements are $2.1 \mu \mathrm{C}, 0.7 \mu \mathrm{C}$, and $0.2 \mu \mathrm{C}$, respectively. Halothane concentrations in oocyte bath are indicated above current traces. $B$ : Halothane depresses $\operatorname{LP}\left(10^{-7} \mathrm{M}\right)$-induced $\mathrm{I}_{\left.\mathrm{Cl}_{(2}\right)}$ in a concentration-dependent manner. The half-maximal inhibitory concentration is $0.23 \pm 0.02 \mathrm{mM}(0.43 \%)$. Each oocyte was exposed to a single halothane concentration only. The number of oocytes used per treatment group is indicated above each data point. $C$ :

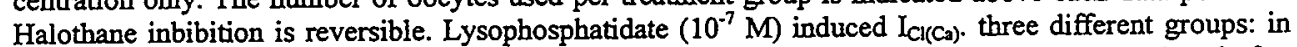
the absence of halothane (first bar), after exposure to $0.34 \mathrm{mM}(0.64 \%)$ halothane (middle bar) and after $0.34 \mathrm{mM}$ halothane exposure followed by a 20 -min wash of Tyrode's solution (last bar). The number of oocytes used per group is indicated. 


\section{CHAPTER 10}

intracellular stores and subsequent activation of $\mathrm{I}_{\mathrm{Cl}(\mathrm{Ca}) .}{ }^{25,26,28}$ The shape of the response is indistinguishable from responses induced by activation of other $G$ protein-coupled receptors.

\section{Halothane reversibly inhibits lysophosphatidate responses in oocytes}

We tested the ability of halothane to interfere with LP signaling. Halothane at clinically relevant concentrations depressed LP-induced $\mathrm{I}_{\mathrm{Cl}(\mathrm{Ca})}$ in a concentration-dependent manner (Figures $2 \mathrm{~A}$ and $\mathrm{B}$ ). In the absence of halothane, average charge movement induced by $10^{-7} \mathrm{M} \mathrm{LP}$ was $1.6 \pm 0.2 \mu \mathrm{C}$. In the presence of $0.34 \mathrm{mM}(0.64 \%)$ halothane, responses to LP were inhibited completely. Curve fitting using the Hill equation revealed a half-maximal inhibitory concentration of $0.23 \pm 0.02 \mathrm{mM}(0.43 \%)$ and a Hill coefficient of $6.3 \pm 2.5$.

To determine if the effect of halothane was reversible, LP-induced currents were tested under three conditions: in the absence and presence of halothane and after exposure to halothane followed by a wash with anesthetic-free solution. Three separate treatment groups were used to prevent multiple agonist applications from desensitizing the LP receptor or intracellular signaling pathways. A high concentration of halothane was used because it was considered more likely to cause irreversible effects. Although LP-induced responses were depressed more than $95 \%$ in the presence of anesthetic, $\mathrm{I}_{\mathrm{Cl}(\mathrm{Ca})}$. obtained in response to $\mathrm{LP}$ after exposure to $0.34 \mathrm{mM}(0.64 \%)$ halothane and a wash with anesthetic-free solution were similar in size to control responses (Figure $2 \mathrm{C}$ ).

\section{Halothane does not inhibit angiotensin responses in oocytes}

In a previous study, we showed that $0.34 \mathrm{mM}(0.64 \%)$ halothane does not affect responses to $10^{-7} \mathrm{M}$ angiotensin II (ATI) in oocytes expressing the $\mathrm{AT}_{1 \mathrm{~A}}$ angiotensin receptor. Apart from the receptor and possibly the $G$ protein, $\mathrm{LP}_{\text {and }} \mathrm{AT}_{1 \mathrm{~A}}$ receptors are presumed to signal through the same intracellular pathway, because they both induce $\mathrm{Ca}^{2+}$ release and $\mathrm{Ca}^{2+}$-activated $\mathrm{Cl}^{-}$channel activation and because the oocyte contains only a single molecular species of phospholipase $\mathrm{C}$ coupling receptor activation to intracellular $\mathrm{Ca}^{2+}$ release. ${ }^{34}$ Therefore, as halothane had no inhibitory effect on angiotensin signaling, halothane's site of action is unlikely to be downstream of the LP receptor and $G$ protein. To confirm our previous data, we expressed $\mathrm{AT}_{1 \mathrm{~A}}$ receptors in oocytes and tested the ability of $0.34 \mathrm{mM}(0.64 \%)$ halothane to inhibit $\mathrm{I}_{\mathrm{Cl}(\mathrm{Ca})}$ induced by $10^{-7} \mathrm{M}$ ATI (as for LP, this concentration is approximately half-maximal in this model ${ }^{35}$ ). As in our previous investigation, halothane at this concentration had no effect (Figure 3). We proceeded to confirm that LP and AT receptors signal through the same transduction pathway and that halothane has no effect on this common signaling pathway.

\section{Lysophosphatidate and angiotensin receptors signal through inositoltrisphosphate}

Both $\mathrm{LP}^{36,37}$ and angiotensin signaling ${ }^{38}$ result in $\mathrm{IP}_{3}$ release. To verify that these receptors indeed signal through this mechanism in our model, we injected heparin (MW $=3,000 ; 60$ $\mathrm{nl}$; final concentration, $120 \mathrm{ng} / \mu \mathrm{l}$ ) into oocytes and tested their ability to respond to agonist application $30 \mathrm{~min}$ later. Heparin antagonizes the effect of $\mathrm{IP}_{3}$ on its receptor and inhibits $\mathrm{PP}_{3}$-mediated $\mathrm{Ca}^{2+}$ responses in oocytes. ${ }^{38}$ To ensure that the intracellular injection process did not impair the signaling ability of the cells, some oocytes were injected with $60 \mathrm{nl}$ water, which 
[HAL]: $\quad 0 \mathrm{mM}$

$0.34 \mathrm{mM}$
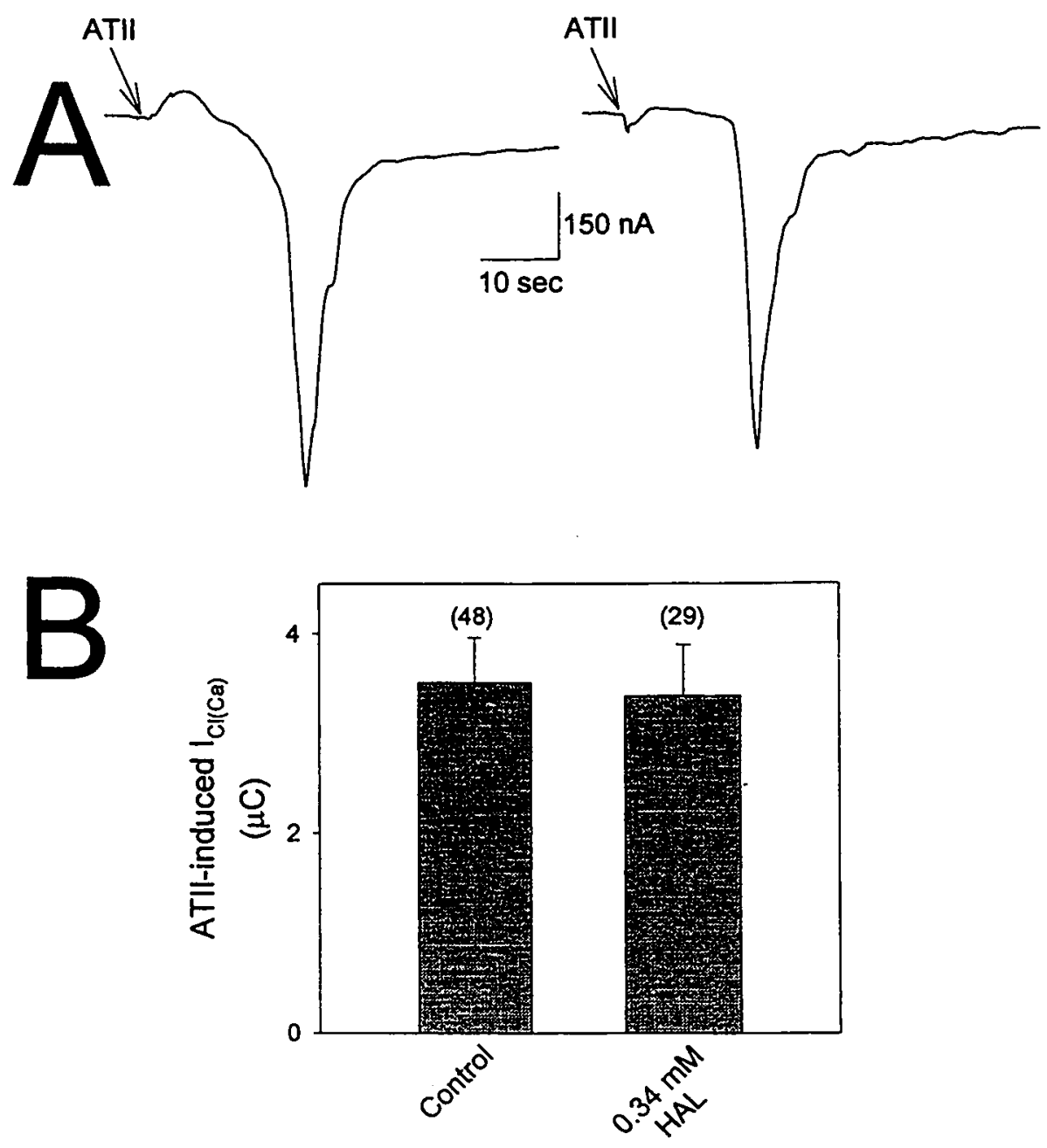

Figure 3. Halothane does not inhibit angiotensin signaling. $A$ : Example traces of $10^{-7} \mathrm{M}$ ATU-induced currents in oocytes expressing $\mathrm{AT}_{\mathrm{IA}}$ angiotensin receptors. The arrow indicates the time of agonist application. Charge movements in the absence and presence of $0.34 \mathrm{mM}$ halothane are 3.8 and $3.4 \mu \mathrm{C}$, respectively. $B$ : Halothane does not significantly inhibit $10^{-7} \mathrm{M}$ ATI-induced currents. The number of oocytes used per treatment group is indicated. 


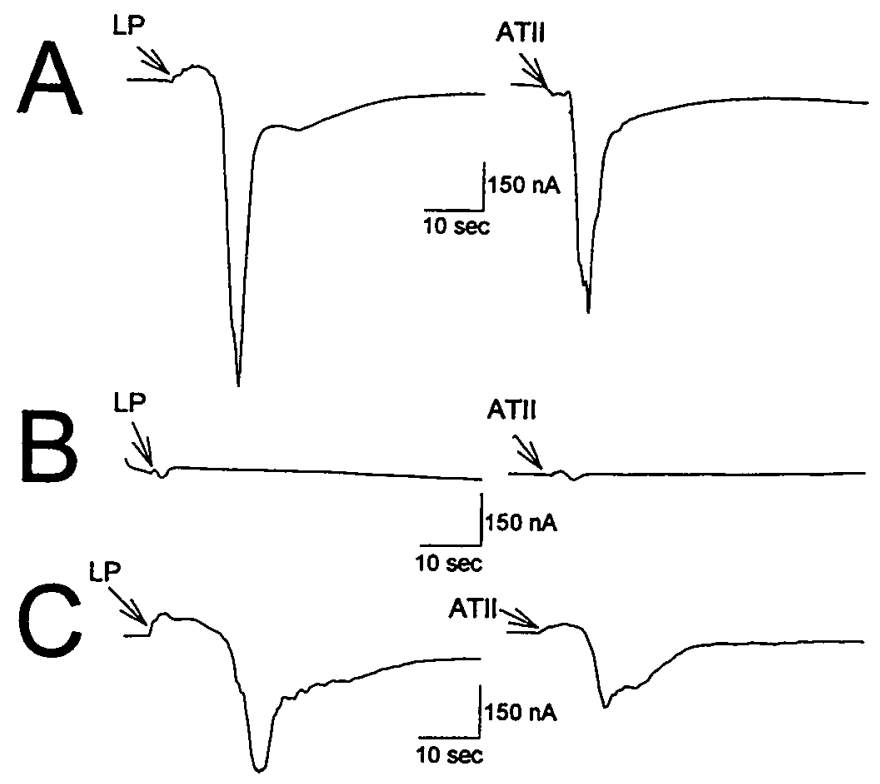

D

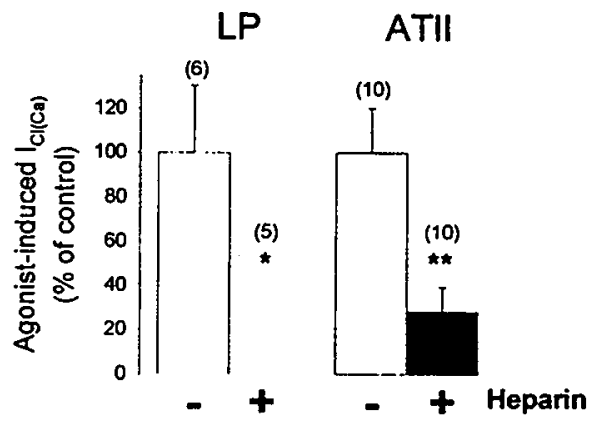

Figure 4. Lysophosphatidate (L.P) and angiotensin receptors signal through inositoltoltrisphosphate $\left(\mathrm{PP}_{3}\right)$. A: Water $(60 \mathrm{nl})$ preinjected into oocytes does not interfere with LP signaling (first trace) or angiotensin (AT) signaling (second trace, in oocyte injected with $\mathrm{AT}_{1 \mathrm{~A}}$ CRNA 3 days previously). Charge movements are $4.6 \mu \mathrm{C}$ and $2.9 \mu \mathrm{C}$, respectively. The arrow indicates the time of agonist application. $B$ : Sample traces of oocytes preinjected with heparin $(60 \mathrm{nl}, 120 \mathrm{ng})$, an $\mathbb{P P}_{3}$ receptor blocker, show inhibition of both LP and AT signaling. $C$ : De-N-sulfated heparin (60 ml, $120 \mathrm{ng}$ ) preinjected into oocytes does not significantly affect LP or AT signaling. Charge movements are $2.8 \mu \mathrm{C}$ and $1.7 \mu \mathrm{C}$, respectively. $D$ : Heparin significantly blocks LP and AT signaling. Agonist (LP or ATII)-induced $I_{C_{1}\left(C_{2}\right)}$ in oocytes (non-RNA injected oocytes for $L P$, and $\mathrm{AT}_{1 \mathrm{~A}}$ CRNA-injected oocytes for AT). + and - refer to oocytes injected and not injected with $120 \mathrm{ng}$ heparin. The number of oocytes per treatment group is indicated *P $<0.05$. $* * \mathrm{P}<0.01$. Pathway downstream of $\mathrm{IP}_{3}$ generation is unaffected by the anesthetic. 
was found to have no effect on LP or ATII-induced $I_{C I(C a)}$ (Figure 4A). However, responses to LP and ATI were blocked significantly by previous heparin injection (Figures $4 \mathrm{~B}$ and D). In contrast, the de-N-sulfated form of heparin, which is a less potent $\mathbb{I P}_{3}$ antagonist, ${ }^{38}$ did not affect agonist-induced responses significantly (Figure $4 \mathrm{C}$ ).

\section{Halothane does not affect inositoltrisphosphate responses in oocytes}

Because lack of effect on AT signaling suggests that halothane does not affect the signaling pathway downstream of receptor or $G$ protein, we wanted to confirm that the anesthetic does not affect the intracellular $\mathrm{Ca}^{2+}$ release system or the $\mathrm{Ca}^{2+}$-activated $\mathrm{Cl}^{-}$channel. For this purpose we injected $\mathrm{IP}_{3}$ into oocytes and determined the effect of halothane on $\mathrm{I}_{\mathrm{CI}(\mathrm{Ca})}$ induced by the compound. Inositol trisphosphate (50 nl; final concentration, $100 \mu \mathrm{M}$ ) induced currents similar in kinetics to those observed with $\mathrm{LP}$ or $\mathrm{AT}_{1 \mathrm{~A}}$ signaling (Figure $5 \mathrm{~A}$ ). In preliminary experiments, we established that this concentration of injected $\mathrm{IP}_{3}$ resulted in response sizes similar to those observed with $10^{-7} \mathrm{MLP}$ or ATII. To ensure that the observed $\mathrm{IP}_{3}$-induced currents were not a result of the injection process, membrane currents were recorded after injections of $50 \mathrm{nl}$ water. Intracellular injection of water did not induce any currents (first trace; Figure 5A). The average $\mathrm{IP}_{3}$-induced response was $4.2 \pm 0.5(\mathrm{n}=22)$. Halothane $(0.34 \mathrm{mM} ; 0.64 \%)$ had no effect on these responses (Figures 5A and B; average charge movement, $4.2 \pm 0.6 \mu \mathrm{C} ; \mathrm{n}=20$ ), indicating that the pathway downstream of $\mathbb{I P}_{3}$ generation is unaffected by the anesthetic.

\section{Isoflurane does not depress lysophosphatidate responses in oocytes}

We also investigated the effects of isoflurane on LP-induced $\mathrm{Cl}^{-}$currents. In contrast to halothane, isoflurane caused only modest depression of LP-induced currents in oocytes (Figure 6). The calculated half-maximal concentration was $0.22 \pm 0.07 \mathrm{mM}(0.46 \%)$, with a Hill coefficient of 3.4 \pm 2.9 . Maximal inhibition was $45 \%$, which was not statistically different from control $(2.7 \pm 0.3 \mu \mathrm{C})$. Thus the effects of these two anesthetics on the LP response in oocytes are quite different.

\section{DISCUSSION}

In this study we show that halothane at clinically relevant concentrations completely inhibits LP, but not AT, responses in Xenopus oocytes. In contrast, equivalent concentrations of isoflurane induced no significant inhibition of LP signaling.

\section{Effects and site of action of lysophosphatidate}

Lysophosphatidate, the simplest natural phospholipid, has many biological effects. Examples include contraction of vascular ${ }^{39}$ and other ${ }^{15}$ smooth muscle; aggregation of human and feline platelets; $;^{21}$ rapid neurite retraction in several neuronal cell lines; $;^{25,40,41, a}$ mitogenesis in

\footnotetext{
- Jalink K: Lysophosphatidate as an extracellular messenger; a study of early cellular effects and mechanism of action. Doctoral thesis, Jalink K. Leiden, the Netherlands, 1993; pp 81-7.
} 

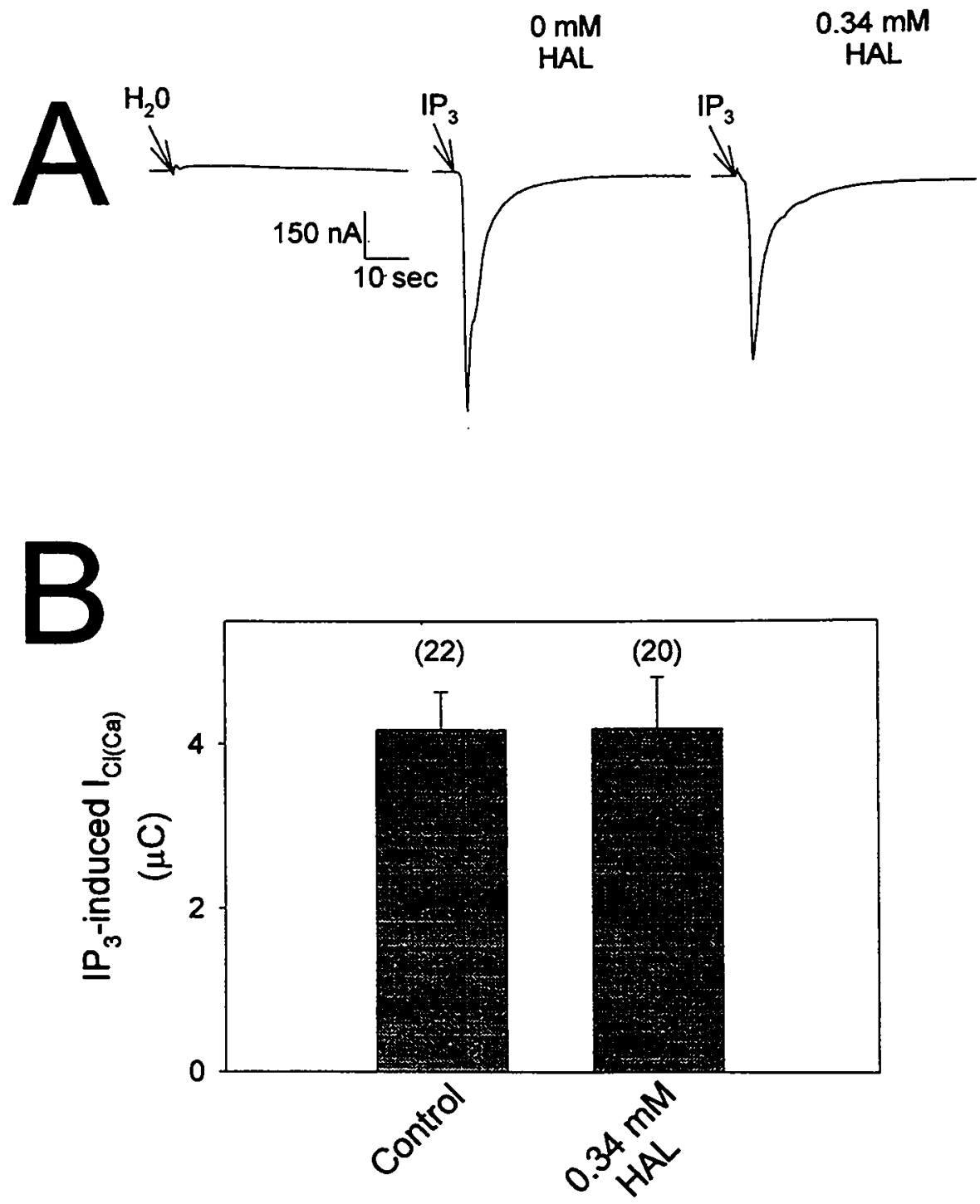

Figure 5. Halothane does not affect inositoltrisphosphate $\left(\mathrm{AP}_{3}\right)$ induced currents. $A$ : Injected water (50 nl) does not elicit a current (first trace), but $100 \mu \mathrm{M} \mathrm{P}_{3}$ (50 nl, middle trace) induces $\mathrm{I}_{\mathrm{CI}(\mathrm{Ca})}$ (charge movement is $3.2 \mu \mathrm{C})$. Halothane $(0.34 \mathrm{mM})$ does not significantly affect $\mathrm{P}_{3}$-induced currents (last trace, charge movement is $2.7 \mu \mathrm{C}$ ). $B$ : Inositoltrisphosphate-induced responses in control oocytes and in those exposed to $0.34 \mathrm{mM}$ halothane are similar. The number of oocytes used per data set is indicated. 
[ISO]: $\quad 0 \mathrm{mM}$

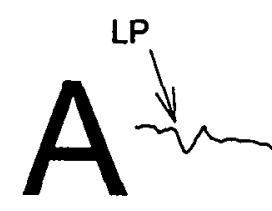

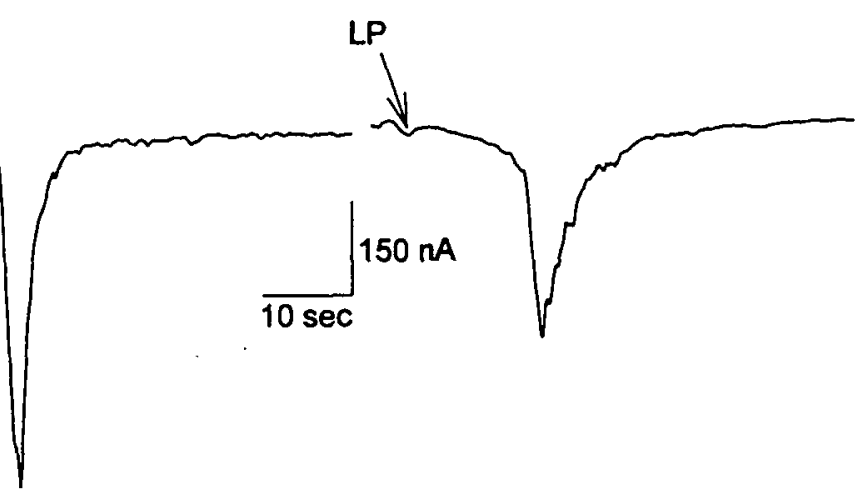

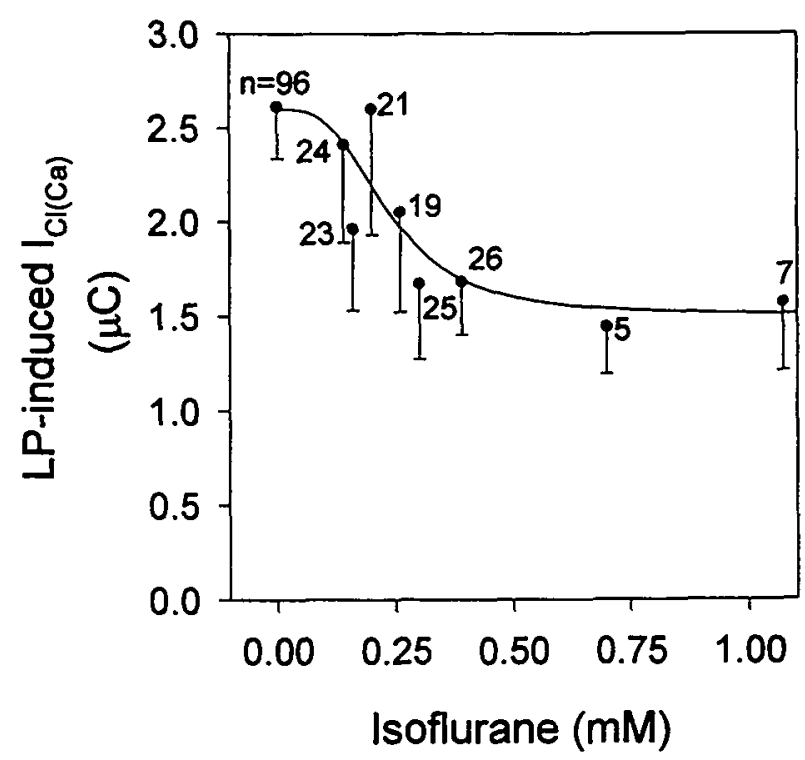

Figure 6. Isoflurane does not significantly affect LP signaling. A: Sample traces of LP-induced $\mathrm{I}_{\mathrm{CI}(\mathrm{Ca})}$ in the absence and presence of isoflurane. Charge movements are $1.9 \mu \mathrm{C}$ and $2.0 \mu \mathrm{C}$, respectively. Isoflurane concentrations in the oocyte bath are indicated above current traces. $B$ : Concentration-response relation of isoflurane effects on LP signaling. Isoflurane does not significantly affect LP $\left(10^{-7} \mathrm{M}\right)$ induced $\mathrm{Cl}^{-}$currents. The half-maximal concentration is $0.22 \pm 0.07 \mathrm{mM}(0.46 \%)$, and maximal depression is $45 \%$. The number of oocytes used per treatment group is indicated above each data point. 
fibroblasts ${ }^{18,19}$ through a mechanism involving $\mathrm{p} 21^{\mathrm{ras}}$ and the mitogen-activated protein (MAP) kinase pathway ${ }^{41,42:}$ and inhibition of proliferation in myeloma cells. ${ }^{43}$ Many of these diverse effects presumably can be reduced to a primary action on the intracellular actin stress fiber system through an effect on the guanine triphosphate (GTP)-binding protein Rho. ${ }^{24,44}$ In addition, the compound inhibits cyclic adenosine monophosphate generation and induces $\mathrm{Ca}^{2+}$ release from intracellular stores through $\mathrm{IP}_{3}$ generation. In Xenopus laevis oocytes, we and other investigators found that $\mathrm{LP}$ induces $\mathrm{I}_{\mathrm{Cl}(\mathrm{Ca})}$ through this mechanism. ${ }^{25-28}$ The compound is released into serum by activated platelets, ${ }^{45,46}$ and its importance is demonstrated by the fact that many of the studies we refer to have shown that well-known serum effects such as neurite retraction and actin reorganization are, in fact, due to LP bound to serum albumin.

Although it has not been cloned yet, many studies document the existence of an LP receptor that couples to a $G$ protein signaling cascade. When microinjected into cells, LP has no effect, implying an extracellular site of action. ${ }^{25,26,36,47}$ Additional evidence for a membrane receptor comes from work done by van der Bend et al. ${ }^{48}$ who, using a photoreactive, radiolabeled, cross-linking LP analog, identified a putative LP membrane receptor of $38-40 \mathrm{kd}$. In addition, responses to LP are blocked by suramin, an inhibitor of many ligand-receptor interactions. Several studies support a $\mathrm{G}$ protein-coupled signaling system for LP. Transient increases in $\mathrm{Ca}^{2+}$ levels in fibroblaststs ${ }^{18,36}$ and oocytes ${ }^{25,26}$ induced by LP have kinetics typical of those of G protein-coupled receptor responses. In addition, some LP-induced responses are sensitive to pertussis toxin, ${ }^{18,26}$ and GTP $\gamma$ S, a nonhydrolyzable GTP analog, potentiates the effects of LP. ${ }^{18,37}$ Lysophosphatidate action is highly specific. Virtually no structurally related compounds induce changes in $\mathrm{Ca}^{2+}$ levels in human fibroblasts or oocytes. Prostaglandins and platelet-activating factor have been shown clearly to signal through other receptor classes. ${ }^{49,50}$

\section{Site of anesthetic inhibition}

The inhibition of LP responses by halothane observed in the present study is likely to occur at the receptor or $G$ protein level. Suggestive evidence for this derives from our finding that angiotensin signaling is not inhibited by halothane concentrations that virtually abolish LP responses. The two agonists are presumed to signal through the same intracellular pathway and have similar potencies in our model. A single phospholipase $C$ type has been shown to be involved in receptor-mediated $\mathrm{Ca}^{2+}$ signaling in oocytes, ${ }^{34}$ making $\mathrm{Ca}^{2+}$ release from similar pools and activation of the same $\mathrm{Cl}^{-}$channel very likely. The indistinguishable response kinetics in these cells supports this. Our heparin microinjection experiments show that both LP and AT receptors signal through $\mathrm{IP}_{3}$-sensitive $\mathrm{Ca}^{2+}$ stores. Furthermore, no other intracellular calcium release channels, such as ryanodine receptors, have been found in oocytes. ${ }^{38}$ Therefore, apart from the receptors, and possibly the coupled G proteins, AT and LP signaling pathways can be considered identical, and lack of halothane on one, but not the other, pathway suggests an effect at the receptor level.

Additional evidence supporting lack of anesthetic interference with intracellular signaling mechanisms derives from our finding that $\mathrm{IP}_{3}$-induced currents are not affected by halothane. This indicates that the anesthetic does not affect the $\mathrm{Ca}^{2+}$ release mechanism or the $\mathrm{Ca}^{2+}$ activated $\mathrm{Cl}^{-}$channel. Our findings correspond with other studies in which low concentrations of halothane were shown not to affect $\mathrm{IP}_{3}$-linked $\mathrm{Ca}^{2+}$ signaling. For example, Smart et al. ${ }^{51}$ studied the effect of halothane $(0.5-1 \%)$ on basal and carbachol-stimulated $\mathrm{IP}_{3}$ production in SH-SY5Y human neuroblastoma cells and found no inhibition but rather a modest enhancement of $\mathrm{IP}_{3}$ for- 
mation in the presence of anesthetic. Hossain and Evers ${ }^{52}$ and Stern et al. ${ }^{53}$ observed that halothane $(0.5 \mathrm{mM})$ had almost no effect on thyrotropin-releasing hormone-induced, $\mathbb{P}_{3}$-mediated intracellular $\mathrm{Ca}^{2+}$ release.

Our data cannot rule out an effect of halothane on the LP molecule itself or on LP binding to albumin. However, such interactions are unlikely to explain our results, because volatile anesthetics also inhibit signaling through $G$ protein-coupled receptors with agonists that are less hydrophobic and do not require albumin for solubilization. We have shown that halothane significantly inhibits signaling through muscarinic acetylcholine receptors. ${ }^{6}$ Lin et al. ${ }^{9}$ reported findings similar to ours, showing that although enflurane $(1.8 \mathrm{mM})$ inhibited muscarinic and serotonin signaling, it did not affect the signaling cascade downstream of phospholipase C. A differential effect of isoflurane and halothane on LP binding to albumin is also unlikely. Although volatile anesthetics have been shown to compete with fatty acids for binding sites on albumin, halothane and isoflurane have similar binding constants: Kd was $1.4 \mathrm{mM}$ for isoflurane and 1.3 $\mathrm{mM}$ for halothane. ${ }^{54,55}$ Therefore, our data are most compatible with an effect of halothane on the $L P$ receptor or its associated $G$ protein.

\section{Anesthetic effects suggestive of lysophosphatidate inhibition}

Besides being a useful model for investigating anesthetic - protein interactions, LP is an important compound to study because it is a likely regulator of cell proliferation, particularly in tumor cells. The lack of selective LP antagonists limits our understanding of this growth modulator, although recent reports, ${ }^{33,56}$ if confirmed, suggest that this problem may be resolved. Suramin inhibits LP responses, but it is nonspecific because it blocks many other growth factor actions. Many studies have shown volatile anesthetics to exhibit effects opposite of those of LP signaling, although some reports are conflicting. As noted earlier, LP is a mitogen and induces stress fiber assembly. Halothane inhibits growth of neuroblastoma cells in a dose-dependent manner by disrupting actin-like microfilaments of the mitotic apparatus. ${ }^{57}$ Similar results were found in other cell types. Halothane also affects the distribution pattern of actin in fibroblasts and neuroblastoma cells ${ }^{58}$ and prevents cell cleavage in sea urchin eggs, ${ }^{59}$ another actin-dependent process. Both enflurane and halothane at equivalent minimum alveolar concentrations interfere with cell division in Tetrabymena pyriformis. ${ }^{60}$ As previously noted, LP is a potent platelet aggregator and decreases cyclic adenosine monophosphate levels in many cell types. In contrast, halothane has been found to decrease aggregation in human platelets ${ }^{61,62}$ accompanied by increased cyclic adenosine monophosphate levels. ${ }^{61}$ Thus the LP antagonist-like properties and some side effects of volatile anesthetics may be due to interference with LP signaling.

\section{CONCLUSIONS}

Our findings show that lipid mediator signaling can be affected profoundly by anesthetics. It should be determined if prostaglandins and platelet-activating factor are similarly inhibited by volatile anesthetics. It is not possible to study direct interactions between anesthetics and the LP receptor, because a binding assay for the LP receptor has not been established. If, however, anesthetic interference with signaling occurs at the LP binding site, the simple molecular structure of many anesthetics might allow elucidation of the molecular determinants that define an LP antagonist. Finally, because the LP receptor is $\mathrm{G}$ protein linked, our findings provide additional 
support for anesthetic interference with $\mathrm{G}$ protein-coupled receptors.

\section{REFERENCES}

1. Lin LH, Chen LL, Harris RA: Enflurane inhibits NMDA, AMPA and kainate-induced currents in Xenopus oocytes expressing mouse and human brain mRNA. FASEB J 1993; 7: 479-485

2. Puil E, El-Beheiry H: Anaesthetic suppression of transmitter actions in neocortex. Br J Pharmacol 1990; 101: 61-66

3. Yamamura T, Harada K, Okamura A, Kemmotsu O: Is the site of action of ketamine anesthesia the N-methyl-D-aspartate receptor? Anesthesiology 1990; 72: 704-710

4. Longoni $B$, Olsen RW: Studies on the mechanism of interaction of anesthetics with GABA-A receptors. Adv Biochem Psychopharmacol 1992; 47: 365-378

5. Quinlan JJ, Gallaher EJ, Firestone LL: Halothane's effects on GABA-gated chloride flux in mice selectivity bred for sensitivity or resistance to diazeparn. Brain Res 1993; 610: 224-228

6. Durieux ME: Halothane inhibits signaling through $\mathrm{ml}$ muscarinic receptors expressed in Xenopus oocytes. Anesthesiology 1995; 82: 174-182

7. Anthony BL, Dennison RL, Aronstam RS: Disruption of muscarinic receptor-G protein coupling is a general property of liquid volatile anesthetics. Neurosci Lett 1989; 99: 191-196

8. Aronstam RS, Anthony BL, Dennison RL: Halothane effects on muscarinic acetylcholine receptor complexes in rat brain. Biochem Pharmacol 1986; 35: 667-672

9. Lin LH, Leonard S, Harris A: Enflurane inhibits the function of mouse and human brain phosphatidylinositol-linked acetylcholine and serotonin receptors expressed in Xenopus oocytes. Molec Pharmacol 1993; 43: 941-948

10. Okamura A, Ohkubo K, Yamamura T, Kemmotsu O, Tohda M, Nomura Y: Inhalational anesthetics depress second messengermediated response of mRNA expressed Xenopus oocyte [sic] (abstract). Anesthesiology 1993; 79:A735

11. Sanna E, Dildy-Mayfield JE, Harris RA: Ethanol inhibits the function of 5-hydroxytryptamine type $\mathrm{lc}$ and muscarinic $\mathrm{M}_{1} \mathrm{G}$ proteinlinked receptors in Xenopus oocytes expressing brain mRNA: Role of protein kinase C. Molec Pharmacol 1994; 45: 10041012

12. Durieux ME, Lynch KR: Signalling properties of lysophosphatidic acid. Trends Pharmacol Sci 1993; 14: 249-254

13. Durieux ME: Lysophosphatidate signaling: Cellular effects and molecular mechanisms. New York, Springer-Verlag/R.G. Landes Company, 1995

14. Moolenaar WH: LPA: A novel lipid mediator with diverse biological actions. Trends Cell Biol 1994; 4: 213-219

15. Tokumura A, Fukuzawa K, Yamada S: Stimulatory effect of lysophosphatidic acids on uterine smooth muscles of non-pregnant rats. Arch Int Pharmacodyn Ther 1980; 245: 74-83

16. Tokumura A, Yabe N, Fujimoto H: Lysophosphatidic acids induce contraction of rat isolated colon by two different mechanisms. J Pharm Pharmacol 1991; 43: 774-778

17. Tokumura A, Fukuzawa K: Contractile actions of lysophosphatidic acids with a chemically-defined fatty acyl group on longitudinal muscle from guinea-pig ileum. J Pharm Pharmacol 1981; 34: 514-516 
18. van Corven EJ, Groenink A, Jalink K, Eichholtz T, Moolenaar WH: Lysophosphatidate-induced cell proliferation: Identification and dissection of signaling pathways mediated by G proteins. Cell 1989; 59: 45-54

19. van Corven EJ, van Rijswijk A, Jalink K, van der Bend RL, van Blitterswijk WJ, Moolenaar WH: Mitogenic action of lysophosphatidic acid and phosphatidic acid on fibroblasts; dependence on acyl-chain length and inhibition by suramin. Biochem J 1992; 281: 163-169

20. Moolenaar WH: Mitogenic action of lysophosphatidic acid. Adv Cancer Res 1991; 57: 87102

21. Schumacher KA, Classen HG, Späth M: Platelet aggregation evoked in vitro and in vivo by phosphatidic acids and lysoderivatives: Identity with substances in aged serum (DAS). Thromb Haemost 1979; 42: 631-640

22. Watson SP, McConnell RT, Lapetina KG: Decanoyl lysophosphatidic acid induces platelet aggregation through an extracellular action; evidence against a second messenger role for lysophosphatidic acid. Biochem J 1985; 232: 61-66

23. Gerrard JM, Robinson P: Lysophosphatidic acid can activate platelets without increasing ${ }^{32}$ P-labelling of phosphatidic acid. Biochim Biophys Acta 1984; 795: 487-492

24. Ridley AJ, Hall A: The small GTP-binding protein rho regulates the assembly of focal adhesions and actin stress fibers in response to growth factors. Cell 1992; 70:389-399

25. Fernhout BJH, Dijcks FA, Moolenaar WH, Ruigt GSF: Lysophosphatidic acid induces inward currents in Xenopus laevis oocytes; evidence for an extracellular site of action. Eur J Pharmacol 1992; 213: 313-315

26. Durieux ME, Salafranca MN, Lynch KR, Moorman JR: Lysophosphatidic acid induces a pertussis toxin-sensitive $\mathrm{Ca}^{2+}$-activated $\mathrm{Cl}^{-}$current in Xenopus laevis oocytes. Am J Physiol 1992; 263: C896-C900

27. Ferguson JE, Hanley MR: Phosphatidic acid and lysophosphatidic acid stimulate receptor-regulated membrane currents in the Xenopus laevis oocyte. Arch Biochem Biophys 1992; 297: 388-392

28. Tigyi G, Miledi R: Lysophosphatidates bound to serum albumin activate membrane currents in Xenopus oocytes and neurite retraction in PC12 pheochromocytoma cells. J Biol Chem 1992; 267: 21360-21367

29. Durieux ME, Carlisle SJ, Salafranca MN, Lynch KR: Endogenous responses to sphingosine-l-phosphate in $X$ laevis oocytes: Similarities with lysophosphatidic acid signaling. Am J Physiol 1993; 264: C1360-C1364

30. Durieux ME: OoClamp: An IBM-compatible software system for the study of receptors expressed in Xenopus oocytes. Comput Methods Programs Biomed 1993; 41:101-105

31. Roth SH, Miller KW: Molecular and cellular mechanisms of anesthetics. New York, Plenum Publishing, 1986, pp 455-70

32. Franks NP, Lieb WR: Selective actions of volatile general anaesthetics at molecular and cellular levels. Br J Anaesth 1993; 71: 65-76

33. Liliom K, Bittman R, Swords B, Tigyi G: N-palmitoyl-serine and N-palmitoyl-tyrosine phosphoric acids are selective competitive antagonists of the lysophosphatidic acid receptors. Molec Pharmacol 1996; 50: 616-623

34. Ma H, Blitzer RD, Healy EC, Premont RT, Landau EM, lyengar R: Receptor-evoked $\mathrm{Cl}^{-}$current in Xenopus oocytes is mediated through a $\beta$-type phospholipase $C$; cloning a new form of the enzyme. J Biol Chem 1993; 268: 19915-19918 
35. Sandberg $\mathrm{K}$, Hong J, lida $\mathrm{T}$, Catt $\mathrm{KJ}$ : Intracellular communication between follicular angiotensin receptors and Xenopus laevis oocytes: Mediation by an inositol 1,4,5-triphosphatedependent mechanism. J Cell Biol 1992; 117: 157-167

36. Jalink K, van Corven EJ, Moolenaar WH: Lysophosphatidic acid, but not phosphatidic acid, is a potent $\mathrm{Ca}^{2+}$-mobilizing stimulus for fibroblasts. J Biol Chem 1990; 265: 12232-12239

37. Plevin R, MacNulty EE, Palmer S, Wakelam MJO: Differences in the regulation of endothelin-1- and lysophosphatidic acid-stimulated Ins $(1,4,5) \mathrm{P}_{3}$ formation in Rat-1 fibroblasts. Biochem J 1991; 280: 609-615

38. Parys JB, Semett SW, DeLisle S, Snyder PM, Welsh MJ, Campbell KP: Isolation, characterization, and localization of the inositol 1,4,5-trisphosphate receptor protein in Xenopus laevis oocytes. J Biol Chem 1992; 267: 18776-18782

39. Tokumura A, Fukuzawa K: Effects of synthetic and natural lysophosphatidic acids on the arterial blood pressure of different animal species. Lipids 1978; 13:572-574

40. Dyer DL, Tigyi G, Miledi R: The effect of active serum albumin on PC12 cells: I. Neurite retraction and activation of the phosphoinositide second messenger system. Molec Brain Res $1992 ; 14: 293-301$

41. Hordijk PL, Verlaan I, van Corven EJ, Moolenaar WH: Protein tyrosine phosphorylation induced by lysophosphatidic acid in Rat-l fibroblasts; evidence that phosphorylation of MAP kinase is mediated by the $\mathrm{G}_{1}-\mathrm{p} 21^{\mathrm{ras}}$ pathway. J Biol Chem 1994; 269: 645-651

42. Corven EJ, Hordijk PL, Medema RH, Bos JL, Moolenaar WH: Pertussis toxin-sensitive activation of $\mathrm{p} 21^{\text {ras }}$ by $\mathrm{G}$ protein-coupled receptor agonists in fibroblasts. Proc Natl Acad Sci USA 1993; 90: 1257-1261

43. Tigyi G, Dyer DL, Miledi R: Lysophosphatidic acid possesses dual action in cell proliferation. Proc Natl Acad Sci USA 1994; 91 : 1908-1912

44. Jalink K, van Corven EJ, Hengeveld T, Moru N, Narumiya S, Moolenaar WH: Inhibition of lysophosphatidate- and thrombin-induced neurite retraction and neuronal cell rounding by ADP ribosylation of the small GTP-binding protein Rho. J Cell Biol 1994; 126: 801-810

45. Gerrard JM, Robinson P: Identification of the molecular species of lysophosphatidic acid produced when platelets are stimulated by thrombin. Biochim Biophys Acta 1989; 1001: 282-285

46. Eichholtz T, Jalink K, Fahrenfort I, Moolenaar WH: The bioactive phospholipid lysophosphatidic acid is released from activated platelets. Biochem J 1993; 291: 677-680

47. Jalink K, Eichholtz T, Postma FR, van Corven EJ, Moolenaar WH: Lysophosphatidic acid induces neuronal shape changes via a novel, receptor mediated signaling pathway: Similarity to thrombin action. Cell Growth Differ 1993; 4: 247-255

48. van der Bend RL, Brunner J, Jalink K, van Corven EJ, Moolenaar WH, Bitterswijk WJ: Identification of a putative membrane receptor for the bioactive phospholipid, lysophosphatidic acid. EMBO J 1992; 11: 2495-2501

49. Tokumura A, Yoshida J, Marnyama T, Fukuzawa K: Platelet aggregation induced by ether-linked phospholipids. 1. Inhibitory actions of bovine serum albumin and structural analogues of platelet activating factor. Thromb Res 1987; 46: 51-63

50. Sugiura T, Tokumura A, Gregory L, Nouchi T, Weintraub ST, Hanahan DJ: Biochemical characterization of the interaction of lipid phosphoric acids with human platelets: Comparison with plateletactivating factor. Arch Biochem Biophys 1994; 311 : 358-68 
51. Smart D, Smith G, Lambert DG: Halothane and isoflurane enhance basal and carbachol-stimulated inositol $(1,4,5)$ triphosphate formation in SH-SY5Y human neuroblastoma cells. Biochem Pharmacol 1994; 47: 939-945

52. Hossain $\mathrm{MD}$, Evers AS: Volatile anesthetic-induced efflux of calcium from $\mathrm{IP}_{3}$-gated stores in clonal $\left(\mathrm{GH}_{3}\right)$ pituitary cells. Anesthesiology 1994; 80: 1379-1389

53. Stern RC, Herrington J, Lingle CJ, Evers AS: The action of halothane on stimulus-secretion coupling in clonal $\left(\mathrm{GH}_{3}\right)$ pituitary cells. J Neurosci 1991; 11:2217-2225

54. Dubois BW, Cherian SF, Evers AS: Volatile anesthetics compete for common binding sites on bovine serum albumin: A ${ }^{19}$ F-NMR study. Proc Natl Acad Sci USA 1993; 90: 6478-6482

55. Dubois BW, Evers AS: ${ }^{19} \mathrm{~F}-\mathrm{NMR}$ spin-spin relaxation $\left(\mathrm{T}_{2}\right)$ method for characterizing volatile anesthetic binding to proteins. Analysis of isoflurane binding to serum albumin. Biochemistry 1992; 31: 7069-7076

56. Bittman R, Swords B, Liliom K, Tigyi G: Inhibitors of lipid phosphatidate receptors: $\mathrm{N}$-palmitoyl-serine and N-palmitoyl-tyrosine phosphoric acids. J Lipid Res 1996; 37: 391-398

57. Telser A, Hinkley RE: Cultured neuroblastoma cells and halothane; effects on cell growth and macromolecular synthesis. Anesthesiology 1977; 46: 102-110

58. Uemura E, Levin ED: The effect of halothane on cultured fibroblasts and neuroblastoma cells. Neurosci Lett 1992; 145: 33-36

59. Hinkley RE, Chambers EL: Structural changes in dividing sea-urchin eggs induced by the volatile anaesthetic halothane. J Cell Sci 1982; 55: 327-339

60. Conklin KA, Lau S: Enflurane effects on cell division and macro-molecular synthesis in Tetraloymena pyriformis; comparison with halothane. Anesthesiology 1980; 53: 287-292

61. Walter F, Vulliemoz Y, Verosky M, Triner L: Effects of halothane on the cyclic $3^{\prime}, 5^{\prime}$-adenosine monophosphate enzyme system in human platelets. Anesth Analg 1980; 59: 856-861

62. Dalgaard-Nielsen J, Gormsen J: Effects of halothane on platelet function. Thromb Haemost 1980 ; 44: 143-145 

CHAPTER 11

Inhibition of lysophosphatidate signaling by lidocaine and bupivacaine

\author{
Gregor W. Nietgen \\ Carrie K. Chan \\ Marcel E. Durieux
}

Anesthesiology 1997; 86: 1112-1119

Reproduced with permission from the publisher. 


\title{
Inhibition of Lysophosphatidate Signaling by Lidocaine and Bupivacaine
}

\begin{abstract}
Background. Lidocaine and bupivacaine impair wound healing, but the mechanism of this side effect has not been determined. The phospholipid messenger lysophosphatidate is released from activated platelets and induces fibroblast and smooth muscle proliferation. Because it may play a role in wound healing, the authors studied the effects of local anesthetics on lysophosphatidate signaling in Xenopus oocytes.

Methods: Defolliculated Xenopus oocytes expressing endogenous G protein-coupled lysophosphatidate receptors were voltage clamped and studied in the presence or absence of lidocaine or bupivacaine. Lysophosphatidate-induced $\mathrm{Ca}^{2+}$-activated $\mathrm{Cl}^{-}$currents $\left(\mathrm{I}_{\mathrm{Cl}(\mathrm{Ca})}\right)$ were measured. To determine the site of action of the local anesthetics on the signaling pathway, the authors studied 1) the effects of local anesthetics on signaling induced by intracellular injection of the second messenger inositoltrisphosphate, and 2) the effects of local anesthetics on functioning of recombinantly expressed angiotensin II receptors signaling through the same pathways as the lysophosphatidate receptor.

Results: Lysophosphatidate signaling was inhibited in the presence of local anesthetics. The half maximal inhibitory concentrations $\left(\mathrm{IC}_{50} \mathrm{~s}\right.$ ) for lidocaine and bupivacaine were $29.6 \mathrm{mM}$ and $4.7 \mathrm{mM}$, respectively. Neither responses induced by inositoltrisphosphate injection nor angiotensin signaling were influenced by local anesthetics.

Conclusions: Lysophosphatidate signaling is inhibited by the extracellular application of lidocaine or bupivacaine. In contrast, inositoltrisphosphate or angiotensin signaling was not affected by local anesthetics. Therefore, local anesthetics have a specific, effect on lysophosphatidate receptor functioning. As the local anesthetic concentrations used were similar to those observed after injection around surgical wounds, lysophosphatidate inhibition may play a role in the observed detrimental effects of local anesthetics on wound healing.
\end{abstract}

Key words: Local anesthetics: Lidocaine; bupivacaine. Lysophosphatidate signaling.

\section{INTRODUCTION}

Local anesthetics impair wound healing in various models. For example, the tensile strength of wounds is decreased when lidocaine is injected in wounds to reduce pain after operation. ${ }^{1}$ Lidocaine, with or without epinephrine, also caused a 13-day delay in surgical wound healing in rats. ${ }^{2}$ Although long-acting local anesthetics are becoming ever more important to provide pain relief after outpatient surgery, their effects on wound healing have not been reported.

The mechanisms responsible for the adverse effects of local anesthetics on wound healing are unclear. Suppression of mucopolysaccharide synthesis has been postulated.' In tissue cultures of fibroblasts, slices of newborn rat skin or in vivo granuloma tissue induced by subcutaneous implantation of steel cylinders in rats, application of lidocaine or bupivacaine inhibited synthesis of collagen to a greater extent than that of noncollagenous proteins. Glycosaminoglycan 
synthesis was found defective as well. ${ }^{3}$ Nevertheless, the specific site of local anesthetic interference in the wound healing process is not known.

Lysophosphatidate is a phospholipid released by activated platelets and injured fibroblasts. ${ }^{4,5}$ The compound activates a specific membrane receptor and, through several coupled $G$ proteins, activates a number of intracellular signaling cascades. ${ }^{6-9}$ Its effects include platelet activation, vasoconstriction, and induction of mitogenesis, particularly in fibroblasts. ${ }^{6,10,11}$ Thus the compound may be released after injury and play a role in wound healing. Therefore, we hypothesized that interference of local anesthetics with the lysophosphatidate signaling pathway might explain this phenomenon. We investigated the effects on lysophosphatidate signaling of lidocaine and bupivacaine, two local anesthetics of different lipid solubility and duration of action.

As a model, we used oocytes of the African clawed toad, Xenopus laevis. These cells express lysophosphatidate-specific $G$ protein-coupled membrane receptors, the activation of which results in a $\mathrm{Cl}^{-}$current induced by intracellular $\mathrm{Ca}^{2+}$ release (Figure $1 \mathrm{~A}$ ). ${ }^{7}$ To localize the site of local anesthetic action, we expressed the angiotensin receptor, which responds to a structurally different agonist but couples to the same intracellular signaling pathway as does the lysophosphatidate receptor. In addition, we determined the effects of the local anesthetics on signaling induced by microinjection of inositoltrisphosphate $\left(\mathrm{IP}_{3}\right)$. Specifically, we tried to answer the following questions:

1. Does lidocaine or bupivacaine interfere with lysophosphatidate-induced $\mathrm{Ca}^{2+}$-activated $\mathrm{Cl}^{-}$ currents; if so, are the calculated half maximal inhibitory concentration $\left(\mathrm{IC}_{50} \mathrm{~s}\right)$ comparable to concentrations reached after subcutaneous injection?

2. Are these effects reversible?

3. Where in the signaling pathway are these effects localized?

\section{MATERIALS AND METHODS}

Oocytes

The study protocol was approved by the Animal Research Committee of the University of Virginia. Adult female Xenopus laevis frogs were obtained from Xenopus I (Ann Arbor, MI) and housed in an established frog colony. To obtain oocytes, frogs were anesthetized with $1 \%$ tricaine (3-aminobenzoic acid ethyl ester) until they became unresponsive, and they were operated on ice. Oocytes were harvested through a $5-\mathrm{mm}$ incision in the lower lateral abdominal wall and immediately placed in modified Barth's solution (containing $88 \mathrm{mM} \mathrm{NaCl}, 1 \mathrm{mM} \mathrm{KCl}, 2.4$ $\mathrm{mM} \mathrm{NaHCO}_{3}, 0.41 \mathrm{mM} \mathrm{CaCl}, 0.82 \mathrm{mM} \mathrm{MgSO}_{4}, 0.3 \mathrm{mM} \mathrm{Ca}\left(\mathrm{NO}_{3}\right)_{2}, 15 \mathrm{mM} \mathrm{HEPES}$, and 0.1 $\mathrm{mM} \mathrm{mg} / \mathrm{ml}$ gentamicin, with $\mathrm{pH}$ adjusted to 7.6). Frogs were returned to the main tank after recovering for 2 days in isolation. Oocytes (Dumont's stage 5 and 6) were defolliculated manually using microforceps and incubated in modified Barth's solution at $18^{\circ} \mathrm{C}$ for $24 \mathrm{~h}$ because this results in more consistent lysophosphatidate responses. 


\section{CHAPTER 11}

\section{Receptor expression}

Endogenous lysophosphatidate receptors were used to evaluate the influence of local anesthetics on lysophosphatidate signaling. The angiotensin receptor was expressed recombinantly. A 1.2-kilobase pair cDNA in the CDM8 vector (Invitrogen, San Diego, CA), encoding the rat $A T_{I A}$ angiotensin $\Pi$ receptor, was a gift from Dr. K. R. Lynch at the University of Virginia. The construct was linearized with the nuclease $X h o$ I and transcribed in vitro by T7 RNA polymerase in the presence of a capping analog. Oocytes were injected with $50 \mathrm{nl} \mathrm{cRNA}(5 \mathrm{ng})$ in water, using an automated microinjector (Nanoject; Drummond Scientific, Broomall, PA). Slight ballooning of the oocyte confirmed the adequacy of injection. The cells were cultured for $72 \mathrm{~h}$ at $18^{\circ} \mathrm{C}$ in modified Barth's solution before study.

\section{Electrophysiologic studies}

Lysophosphatidate or angiotensin receptor activation in the oocyte leads to $G$ protein-mediated phospholipase $\mathrm{C}$ activity and release of $\mathrm{IP}_{3}$ from phosphoinositolbisphosphate (Figure 1A). Inositoltrisphosphate then binds to its specific receptor on intracellular $\mathrm{Ca}^{2+}$ stores to release $\mathrm{Ca}^{2+}$, which in turn opens an endogenous $\mathrm{Ca}^{2+}$-activated $\mathrm{Cl}^{-}$channel. The resulting current can be measured using a voltage clamp, and this $\mathrm{Ca}^{2+}$-activated $\mathrm{Cl}^{-}$current $\left(\mathrm{I}_{\mathrm{Cl}(\mathrm{Ca})}\right)$, integrated and expressed in microcoulombs $(\mu \mathrm{C})$, is a measure of intracellular $\mathrm{Ca}^{2+}$ release. ${ }^{8,12-14}$ All experiments were performed at room temperature (approximately $22^{\circ} \mathrm{C}$ ).

Microelectrodes were pulled in one stage from capillary glass (BBL with fiber; World Precision Instruments, Sarasota, FL) on a micropipette puller (model 700C; David Kopf Instruments, Tujunga, CA). Tips were broken to a diameter of approximately $10 \mu \mathrm{m}$, providing a resistance of 1-3 M $\Omega$, and filled with $3 \mathrm{M} \mathrm{KCl}$. A single oocyte was placed in a perfusable bath containing $3 \mathrm{ml}$ Tyrode's solution (consisting of $150 \mathrm{mM} \mathrm{NaCl}, 5 \mathrm{mM} \mathrm{KCl}, 1 \mathrm{mM} \mathrm{MgCl}$, $2 \mathrm{mM}$ $\mathrm{CaCl}_{2}, 10 \mathrm{mM}$ dextrose, and $10 \mathrm{mM}$ HEPES, with the $\mathrm{pH}$ adjusted to 6.4 with $\mathrm{NaOH}$ ) with or without local anesthetic. Two microelectrodes were inserted into the oocyte, and a holding potential of $-70 \mathrm{mV}$ was applied to the membrane. The voltage clamp amplifier (OC725A; Warner Corp., New Haven, CD) was connected to a data acquisition and analysis system running on an IBM-compatible personal computer. The acquisition system was a DAS-8 A/D conversion board (Keithly-Metrabyte, Taunton, MA), and analysis was performed with OoClamp software. ${ }^{15}$ Occasional cells that did not show a stable holding current less than $1 \mu \mathrm{A}$ during a 1-min equilibration period were excluded from analysis. Membrane current was sampled at $125 \mathrm{~Hz}$ and recorded for $5 \mathrm{~s}$ before and $55 \mathrm{~s}$ after application of the agonist (lysophosphatidate or angiotensin, $10^{-7} \mathrm{M}$ ). Agonists were delivered in $30-\mu \mathrm{l}$ aliquots during 1 or $2 \mathrm{~s}$ using a micropipettor positioned approximately $1 \mathrm{~mm}$ from the oocyte. Responses were quantified by integrating the current trace by quadrature and are reported as microcoulombs because this reflects intracellular $\mathrm{Ca}^{2+}$ release better than peak current does. ${ }^{16}$ Oocytes were preincubated with local anesthetics at least $2 \mathrm{~min}$ before agonists were applied. In pilot experiments we found that inhibition develops within $60 \mathrm{~s}$ after exposure to the local anesthetic.

For intracellular injections of $\mathrm{IP}_{3}$, a third microelectrode connected to an automated microinjector (Nanoject) was inserted into the oocyte. Cells were injected under voltage clamp, and the adequacy of injection was verified by observing the small increase in cell size on injection. 

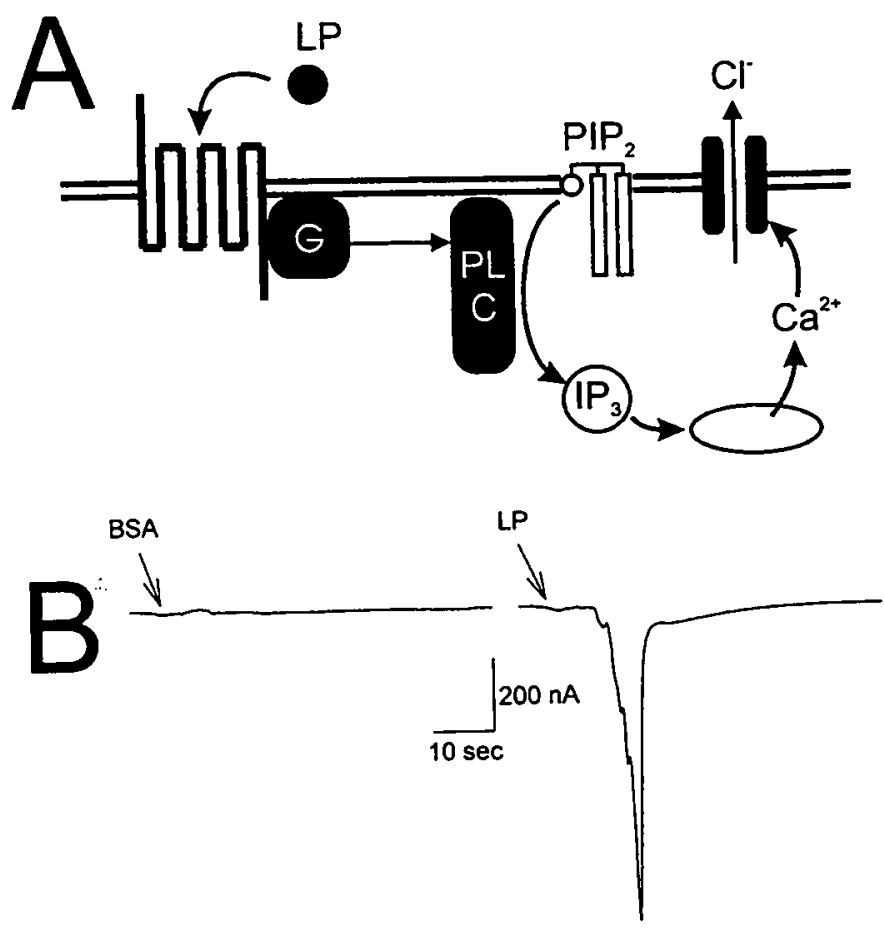

Figure 1. Endogenous lysophosphatidate signaling in Xenopus laevis oocytes. A: Signaling pathway linking activation of the lysophosphatidate receptor to chloride $\left(\mathrm{Cl}^{-}\right)$channel opening. The double line represents the cell membrane. The agonist lysophosphatidate binds to a $G$ protein-coupled receptor, and the $G$ protein activates phospholipase $C$. Phospholipase $C$ releases inositoltrisphosphate $\left(\mathrm{IP}_{3}\right)$ from cell membrane-bound phosphatidylinositolbisphosphate. Calcium $\left(\mathrm{Ca}^{2+}\right)$ is released from $\mathrm{IP}_{3}$-sensitive intracellular stores and activates a Ca${ }^{2+}$-dependent $\mathrm{Cl}^{-}$channel in the cell membrane. $B$ : Example of inward $\mathrm{Ca}^{2+}$-activated $\mathrm{Cl}^{-}$current $\left(\mathrm{I}_{\left.\mathrm{Cl}_{(\mathrm{C} 2}\right)}\right)$ induced by $10^{-7} \mathrm{M}$ lysophosphatidate in a defolliculated oocyte. The vehicle, $1 \%$ bovine serum albumin, has no effect. The current is integrated and expressed as charge movement $(2.9 \mu \mathrm{C})$.

\section{Analysis}

Results are reported as means \pm standard error of the mean. Because variability among batches of oocytes is common, responses were at times normalized to controls for each batch. Differences between treatment groups were analyzed using analysis of variance and Student's unpaired $t$ test. Probability values less than 0.05 were considered significant.

\section{Materials}

Molecular biology reagents were obtained from Promega (Madison, WI), and other chemicals were obtained from Sigma Chemical Company (St. Louis, $\mathrm{MO}$ ). Lidocaine $\mathrm{HCl}$ and 

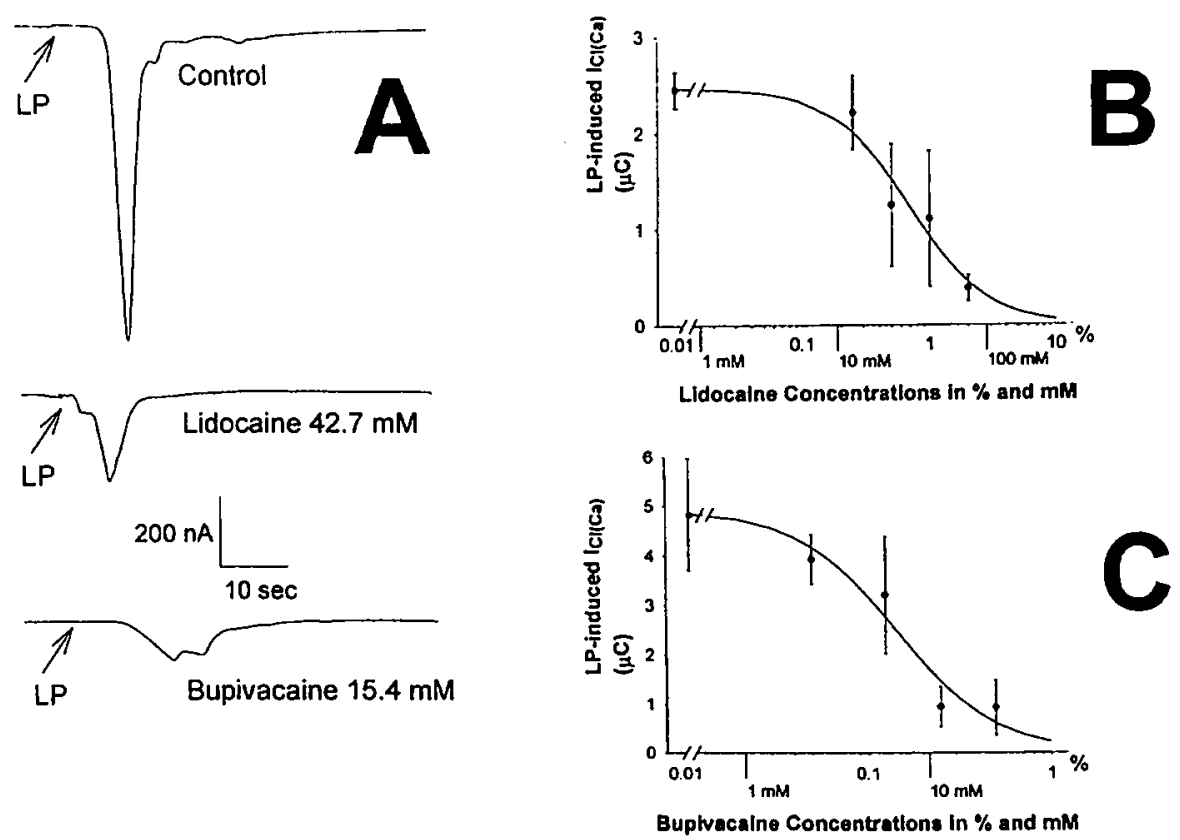

Figure 2. Local anesthetics inhibit lysophosphatidate signaling. $A$ : The $\mathrm{Ca}^{2+}$-activated $\mathrm{Cl}^{-}$current $\left(\mathrm{I}_{\mathrm{Cl}(\mathrm{Ca})}\right)$ induced by $10^{-7} \mathrm{M}$ lysophosphatidate in control oocyte $(4.6 \mu \mathrm{C})$. Below is an example of lysophosphatidate signaling inhibition by $42.7 \mathrm{mM}$ lidocaine $(1.5 \mu \mathrm{C})$ and $15.5 \mathrm{mM}$ bupivacaine $(1.1 \mu \mathrm{C})$. $B$ : Lidocaine depresses lysophosphatidate-induced $\mathrm{I}_{\mathrm{C}\left(\mathrm{C}_{2}\right)}$ in a dose-dependent manner. The half maxi$\mathrm{mal}$ inhibitory concentration $\left(\mathrm{IC}_{50}\right)$ is $29.6 \pm 8.2 \mathrm{mM}$. C: Bupivacaine depresses lysophosphatidate-induced $\mathrm{I}_{\mathrm{Cl}\left(\mathrm{C}_{2}\right)}$ in a dose-dependent manner. The $\mathrm{IC}_{50}$ is $4.5 \pm 1.2 \mathrm{mM}$.

bupivacaine $\mathrm{HCl}$ (Sigma Chemical Co.) were diluted in Tyrode solution. Because of bupivacaine's low solubility at $\mathrm{pH}$ values greater than 6.4 , all solutions were adjusted to $\mathrm{pH}$ of 6.4 , and pilot experiments showed that lysophosphatidate and angiotensin signaling were not influenced by this lower value. Consecutive dilutions for dose-response calculations were made with pH-adjusted Tyrode's solution. Lysophosphatidate (1-oleoyl-2-hydroxy-sn-glycero-3-phosphate [sodium salt]; Avanti Polar Lipids, Alabaster, AL) was prepared as a $10^{-4} \mathrm{M}$ stock solution in $1 \%$ delipidated bovine serum albumin (ICN Biomedicals, Aurora, $\mathrm{OH}$ ). Consecutive dilutions to $10^{-7} \mathrm{M}$ were made in Tyrode's solution. Before experiments, lysophosphatidate solutions were sonicated for $5 \mathrm{~s}$ using a Branson Sonifier 250 (Misonix, Farmingdale, NY) to ensure that the compound was fully in solution. All other chemicals were obtained from Sigma Chemical Company. 


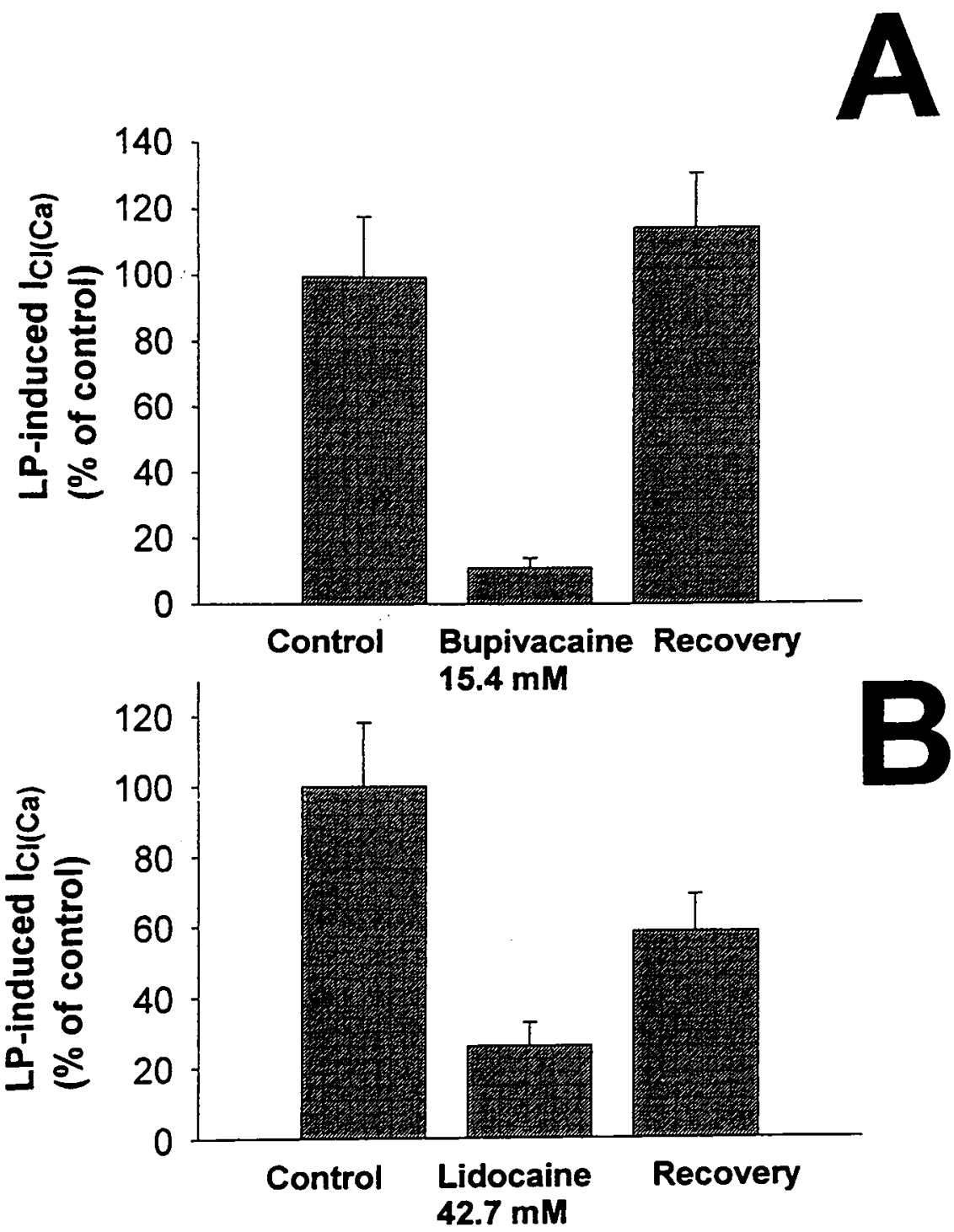

Figure 3. Reversibility of local anesthetic inhibition of lysophosphatidate signaling. $A$ : With 15.5 $\mathrm{mM}$ bupivacaine. $B$ : With $42.7 \mathrm{mM}$ lidocaine. Agonist was lysophosphatidate $10^{-7} \mathrm{M}$ throughout. The first bar shows control responses to lysophosphatidate; the second bar shows inhibition of lysophosphatidate signaling by the local anesthetic. Recovery experiments as shown in the third bar of the graphs were conducted by placing the oocyte in local anesthetic solution for $5 \mathrm{~min}$ and then washing for $5 \mathrm{~min}$ before lysophosphatidate treatment (average control response, $3.1 \mu \mathrm{C}$; control group, $\mathrm{n}=25$; other groups, $\mathrm{n}=$ $5)$. 


\section{RESULTS}

\section{Lysophosphatidate responses in Xenopus oocytes}

Oocytes responded to $30 \mu 10^{-7} \mathrm{M}$ lysophosphatidate with a transient inward current (Figure 1B). The vehicle (bovine serum albumin) had no effect. The current developed after 1-3 $s$ and consisted of a fast component and a gradual return to baseline in 10 to $20 \mathrm{~s}$, which is the typical response to $\mathrm{G}$ protein-coupled receptor stimulation in Xenopus oocytes. The average control response was $2.4 \pm 0.2 \mu \mathrm{C}$.

\section{Local anesthetic effects on lysophosphatidate signaling}

Lysophosphatidate signaling was inhibited when oocytes were exposed to lidocaine or bupivacaine at concentrations used clinically for injection around wounds (Figure 2A). The inhibitory effect was concentration dependent; the $\mathrm{IC}_{50}$ was $29.9 \pm 8.2 \mathrm{mM}$ for lidocaine (Figure $2 \mathrm{~B}$ ) and $4.5 \pm 1.2 \mathrm{mM}$ for bupivacaine (Figure $2 \mathrm{C}$ ). Hill coefficients were 1.5 and 1.6, respectively. At high local anesthetic concentrations, virtually complete inhibition of lysophosphatidate signaling was observed. In the presence of local anesthetics, a modest but consistent slowing of the response was noted, which was not investigated further.

\section{Reversibility of local anesthetic effects on lysophosphatidate signaling}

The reversibility of the local anesthetic inhibitory effect on lysophosphatidate signaling was investigated in three separate groups of oocytes because we were concerned that multiple lysophosphatidate applications might desensitize the lysophosphatidate receptor (Figure 3). In the first group, responses to $10^{-7} \mathrm{M}$ lysophosphatidate were recorded in Tyrode's solution. In the second group, responses were determined in the presence of $42.8 \mathrm{mM}$ lidocaine $(1 \%)$ or 15.4 $\mathrm{mM}$ bupivacaine $(0.5 \%)$; inhibitions to $26 \pm 7 \%$ and $11 \pm 3 \%$, respectively, of control values were seen. In the third group, oocytes were first placed in $42.8 \mathrm{mM}$ lidocaine or $15.4 \mathrm{mM}$ bupivacaine for $5 \mathrm{~min}$, which was then completely washed out with Tyrode's solution. After $5 \mathrm{~min}$ of washing, responses to lysophosphatidate were recorded. Responses after bupivacaine washout were $115 \pm 17 \%$ of control, and thus inhibition by bupivacaine was completely reversible. Responses after lidocaine washout were $58 \pm 11 \%$ of control. Although this was not significantly different from control values, it suggests a prolonged and possible irreversible effect of lidocaine.

\section{Site of action: effects on angiotensin ${ }_{1 A}$ signaling}

To determine that the effect of lidocaine and bupivacaine on lysophosphatidate signaling was specific and not due to nonspecific membrane interactions or inhibition of the $\mathrm{Cl}^{-}$channel, we expressed the angiotensin ${ }_{1 \mathrm{~A}}$ receptor, which, like the lysophosphatidate receptor, is a member of the $G$ protein-coupled receptor superfamily. The angiotensin ${ }_{1 A}$ receptor, when expressed in oocytes, also induces $\mathrm{I}_{\mathrm{Cl}(\mathrm{Ca})}$ through a mechanism that, apart from receptor and possibly $\mathrm{G}$ protein, is considered to be the same as that for lysophosphatidate signaling. Lack of local anesthetic inhibition on angiotensin signaling would make unlikely a nonspecific membrane effect or 

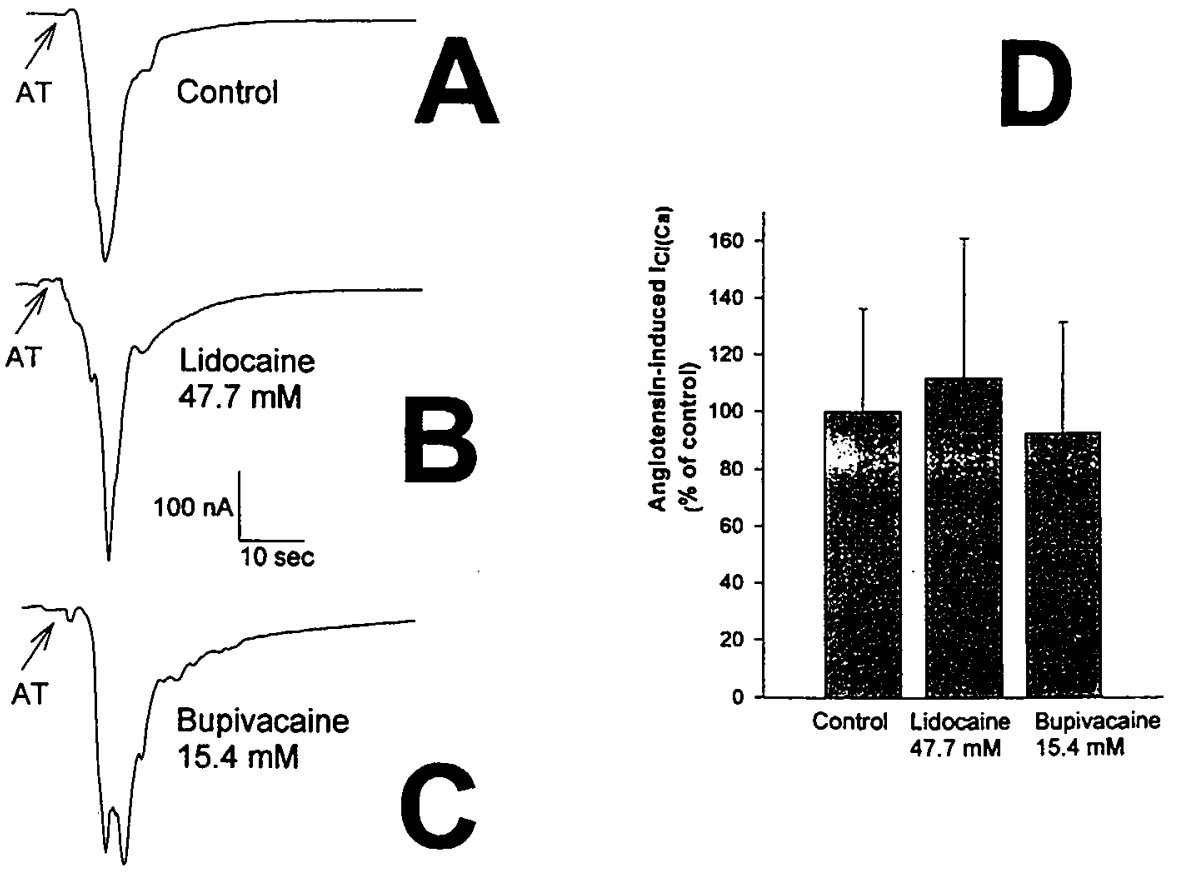

Figure 4. Angiotensin signaling is not inhibited by local anesthetics. $A$ : Control response to $10^{-7} \mathrm{M}$ angiotensin after injection of angiotensin ${ }_{1 \mathrm{~A}} \mathrm{cRNA}$ into oocyte $72 \mathrm{~h}$ before $(2.2 \mu \mathrm{C}) . B, C$ : Lidocaine $42.7 \mathrm{mM}$ and bupivacaine $15.4 \mathrm{mM}$ have no effect on angiotensin signaling. Responses were 2.8 and $3.1 \mu \mathrm{C}$, respectively. (D) Lidocaine $42.7 \mathrm{mM}$ and bupivacaine $15.4 \mathrm{mM}$ have no significant effect on angiotensin signaling (all groups $n=10$ ).

an effect on the signaling pathway downstream of the lysophosphatidate receptor (including the $\mathrm{Cl}^{-}$channel). Angiotensin $\Pi\left(10^{-7} \mathrm{M}\right)$ induced no responses in uninjected oocytes (data not shown) but induced currents in angiotensin ${ }_{1 A}$-injected oocytes that were indistinguishable from those induced by lysophosphatidate (Figure $4 \mathrm{~A}$; the average control response was $1.6 \mu \mathrm{C}$ ). Lidocaine and bupivacaine were without effect on angiotensin signaling. $\mathrm{I}_{\mathrm{Ca}(\mathrm{Cl})}$ in response to $10^{-7} \mathrm{M}$ angiotensin were $111.1 \pm 22 \%$ of control in the presence of lidocaine (42.7 $\left.\mathrm{mM}\right)$ and 92.1 $\pm 38.1 \%$ of control in the presence of bupivacaine $(15.5 \mathrm{mM}$ ) (Figure 4$)$. Therefore bupivacaine and lidocaine do not appear to affect the oocyte membrane, intracellular pathways, or the $\mathrm{Ca}^{2+}$ activated $\mathrm{Cl}^{-}$channel. 

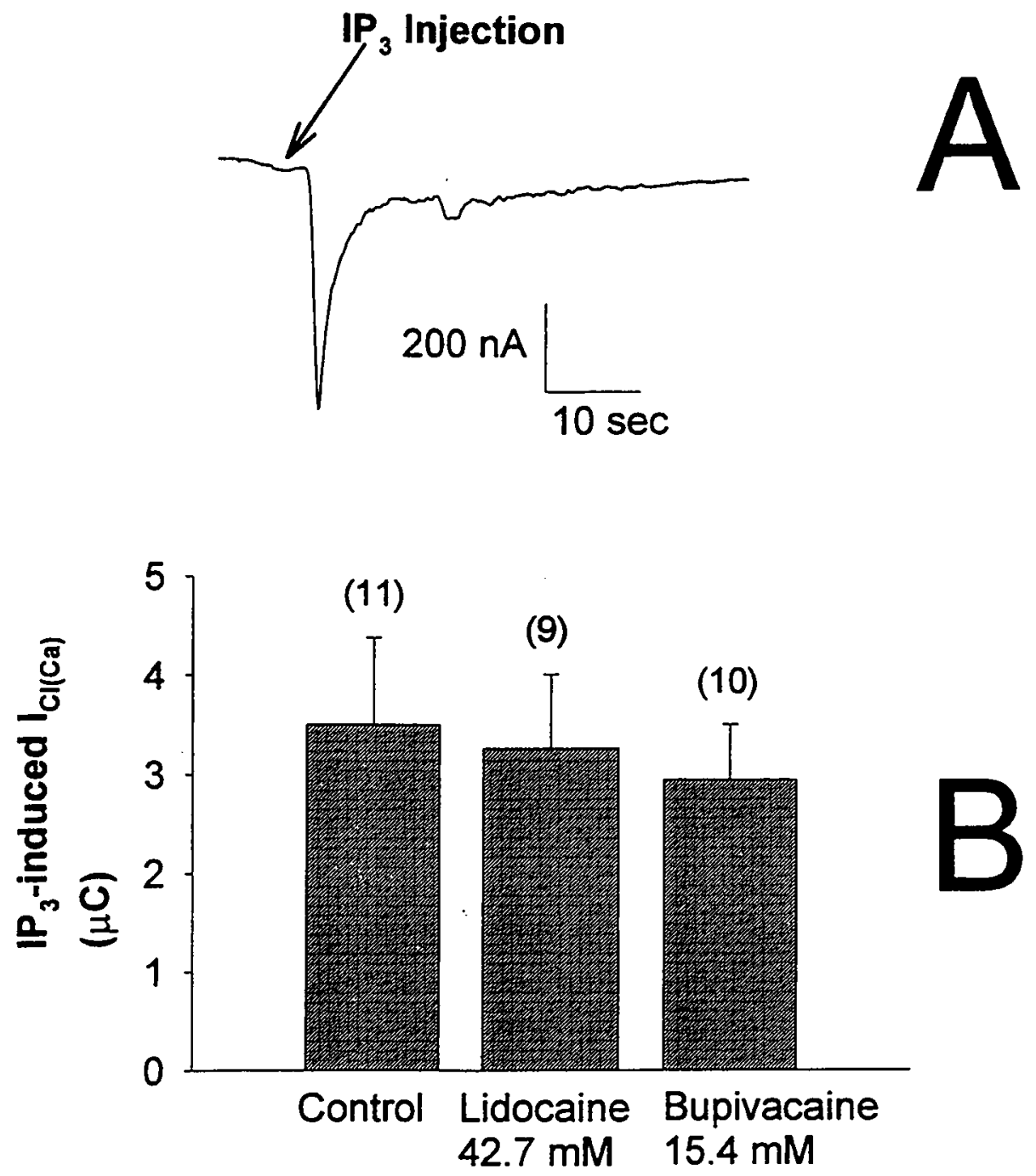

Figure 5. :Local anesthetics have no effect on inositoltrishosphate $\left(\mathrm{IP}_{3}\right)$ signaling. $A: \mathrm{A}$ 50-nl volume of $\mathrm{IP}_{3}(100 \mathrm{mM})$ generates an $\mathrm{I}_{\mathrm{C}_{(}\left(\mathrm{C}_{2}\right)}$ similar to those induced by lysophosphatidate or angiotensin. $B$ : No significant inhibition of $\mathrm{IP}_{3}$-induced $\mathrm{I}_{\left.\mathrm{Cl}_{(3)}\right)}$ is observed when $42.7 \mathrm{mM}$ lidocaine or $15.4 \mathrm{mM}$ bupivacaine are added to the bath solution (the number of cells tested is shown in parentheses). 
To confirm that local anesthetics do not interfere with intracellular $\mathrm{Ca}^{2+}$ release or the $\mathrm{Ca}^{2+-}$ activated $\mathrm{Cl}^{-}$channel, we determined the effects of lidocaine and bupivacaine on $\mathrm{I}_{\mathrm{Cl}(\mathrm{Ca})}$ induced by microinjection of $\mathbb{P}_{3}$ into the oocyte. Previously we showed that heparin, an $\mathrm{IP}_{3}$ receptor antagonist, inhibits lysophosphatidate-induced $\mathrm{I}_{\mathrm{Cl}\left(\mathrm{C}_{a}\right)}$ completely, indicating that lysophosphatidate-induced $\mathrm{Ca}^{2+}$ release is mediated solely by $\mathrm{IP}_{3}{ }^{6,12-14}$

Intracellular injection of $50 \mathrm{nl}$ of $100 \mathrm{mM} \mathrm{IP}_{3}$ generated $\mathrm{I}_{\mathrm{Cl}(\mathrm{Ca})}$ in the oocyte indistinguishable from those induced by extracellular lysophosphatidate (Figure 5A). However, in contrast to currents induced by lysophosphatidate application, size and kinetics of these responses were not affected by the presence of extracellular local anesthetic. Average responses to $\mathrm{IP}_{3}$ were $3.5 \pm$ $0.9 \mu \mathrm{C}$ in the control group, $3.3 \pm 0.8 \mu \mathrm{C}$ in the presence of $42.7 \mathrm{mM}$ lidocaine, and $3.0 \pm 0.6 \mu \mathrm{C}$ in the presence of $15.5 \mathrm{mM}$ bupivacaine (Figure 5B). These findings confirm that lysophosphatidate signaling inhibition by local anesthetics occurs early in the signaling pathway.

\section{DISCUSSION}

Our data show that the local anesthetics lidocaine and bupivacaine inhibit lysophosphatidate signaling in a concentration-dependent manner, with appreciable inhibition occurring at concentrations similar to those observed after injection around wounds. Lack of effect on signaling by angiotensin or microinjected $\mathrm{IP}_{3}$ suggests that the lysophosphatidate receptor environment (receptor molecule, its lipid environment, or coupled $G$ protein) is the site of action. These findings indicate that local anesthetics can interact significantly with lipid mediator receptors. More specifically, they may explain some observed effects of local anesthetics on the wound healing process. As bupivacaine is, and ropivacaine likely will be, used commonly to provide pain relief after surgery, the interactions of these long-acting local anesthetics with wound healing deserve to be studied in detail.

Several potential limitations of our model should be considered. First, we have only studied a single form of lysophosphatidate signaling $\left(\mathrm{Cl}^{-}\right.$currents induced by intracellular $\mathrm{Ca}^{2+}$ release), whereas several intracellular signaling cascades are activated by lysophosphatidate: decreases in CAMP, activation of Rho, prostaglandin synthesis, and ras activation, to mention just a few. No data suggest that these effects are transduced through different subtypes of receptor. Instead they are transduced through several $G$ proteins, presumably coupling to a single, as yet uncloned, receptor subtype. ${ }^{6}$ Given the importance of intracellular $\mathrm{Ca}^{2+}$ signaling, we chose phospholipase $\mathrm{C}$ activation and $\mathrm{IP}_{3}$ release as a pathway to investigate. Second, we used Xenopus oocytes to study this pathway, and consequently we performed our experiments at room temperature. This raises the question if the Xenopus lysophosphatidate receptor might behave differently from its mammalian counterpart. However, there is no molecular biological or pharmacologic evidence to suggest significant functional differences between lysophosphatidate receptors in various tissues. We have shown that the oocyte model closely replicates findings in other systems. ${ }^{11,14,16}$ The angioten $\sin _{\mathrm{IA}}$ receptor derives from rat and therefore was expressed at a lower temperature than it normally functions in. However, this has not been shown to affect its signaling properties appreciably. Temperature differences in oocytes primarily affect latency of response of expressed receptors. ${ }^{17}$ Therefore we believe that the flexibility of the oocyte model outweighs these minor disadvantages. 
The role of lysophosphatidate in wound healing is not known. However, because the compound is released primarily from activated platelets ${ }^{18}$ and injured fibroblasts, ${ }^{5}$ its presence in appreciable quantities around wounds seems likely. We have found in preliminary experiments that lysophosphatidate is absent in healthy skin but released in significant quantities after injury. Because its most prominent effects are fibroblast ${ }^{9,19}$ and smooth muscle cell ${ }^{20}$ proliferation, vasoconstriction, ${ }^{21}$ platelet activation, ${ }^{22,23}$ and induction of changes in cell motility, ${ }^{24-26}$ it seems unlikely that its presence in wounds would have no effect on the wound healing process. Therefore we postulate that lysophosphatidate plays a physiologic role in wound healing, and that interference of local anesthetics with lysophosphatidate signaling can adversely affect the healing process.

Adverse effects of local anesthetics on wound healing have been well described, ${ }^{1-3,27}$ but the mechanisms remain unclear. Although local anesthetics are present in the wound for a short time only, their effects are noticeable for longer periods. For example, fibroblast proliferation and collagen deposition are impaired after application of local anesthetics ${ }^{3}$ and might explain subsequent decreases in wound breaking strength. ${ }^{1}$ Although collagen deposition does not occur until 3-5 days after wounding, ${ }^{28}$ a time when the local anesthetic is unlikely to be present still in appreciable concentrations, local anesthetic-induced delays in fibroblast proliferation could explain this. Transient inhibition of lysophosphatidate signaling in the early stages of wound healing may disturb the subsequent wound healing cascade. Alternatively, an irreversible component of lidocaine block of lysophosphatidate signaling, as suggested by our findings, might play a role. Clinically, signs of inflammation and occasional necrosis have been observed after local anesthetics were administered around wounds. ${ }^{1,27,29}$ Inhibition of proliferation and motility of immune system cells by local anesthetic block of lysophosphatidate signaling might explain some of these findings. On the other hand, inhibition of lysophosphatidate signaling by local anesthetics might have beneficial effects as well. Lysophosphatidate-induced vasoconstriction and platelet aggregation may be important immediately after wounding but will decrease blood flow in the regenerating wound bed. Local anesthetics might reverse this and thereby provide a better healing environment. Indeed, local anesthetics have been shown to inhibit platelet aggregation, ${ }^{30-32}$ and reverse vasospasm, ${ }^{33-36}$ by mechanisms that have not been identified yet.

The exact site of interaction between the local anesthetics and the lysophosphatidate signaling pathway is important. Although the main site of action of local anesthetics is the $\mathrm{Na}^{+}$ channel, ${ }^{37}$ secondary activities exist. For example, local anesthetics inhibit $\mathrm{Ca}^{2+}$ entry through voltage-gated channels, by direct interference with the channel molecule. ${ }^{38}$ In our study, we could rule out an effect of the anesthetics on the $\mathrm{Ca}^{2+}$-activated $\mathrm{Cl}^{-}$channel. As $\mathrm{G}$ protein-coupled pathways signal over many more intermediates than channels do, localization of the site of anesthetic action is relevant. The lack of effect after intracellular microinjection of $\mathrm{IP}_{3}$ suggests that the site of action is proximal in the signaling pathway. This is confirmed by the lack of local anesthetic effect on angiotensin signaling. The latter finding, in addition, makes a nonspecific membrane effect unlikely. Therefore, the most likely site of action is the lysophosphatidate receptor itself. The lipid moiety of the local anesthetic molecule might interact with the presumed hydrophobic agonist binding site on the receptor. It is important that the more lipophilic local anesthetic bupivacaine (octanol-buffer partition coefficient $3420^{39}$ ) inhibited lysophosphatidate signaling at significantly lower concentrations than did lidocaine (partition coefficient $366^{39}$ ). (The agonist binding site might allow other anesthetic interactions, as we have shown recently that the lipophilic anesthetic propofol similarly interferes with lysophosphatidate signaling. ${ }^{40}$ Although the sigmoidal shape of the concentration-inhibition relation is compatible 
with a receptor site of action, the variability associated with high lysophosphatidate concentrations ${ }^{7,14}$ makes it difficult to show competitive interactions conclusively. One other potential site of action deserves further study, namely a direct interaction with the lysophosphatidate molecule, or with lysophosphatidate binding to albumin, its physiologic carrier.

Our data indicate that commonly used local anesthetics can interfere significantly with lipid mediator signaling. Various lipid mediators (platelet-activating factor, prostaglandins, leukotrienes) are relevant in the perioperative context, making it important to understand their interactions with commonly used local anesthetics. This is of particular relevance to the newer, long-acting compounds.

\section{REFERENCES}

1. Morris T, Tracey J: Lignocaine: its effect on wound healing. Br J Surg 1977; 64: 902-903

2. Davies $B$, Guyuron $B$, Husami $T$ : The role of lidocaine, epinephrine, and flap elevation in wound healing after chemical peel. Ann Plast Surg 1991; 26: 273-278

3. Chvapil M, Hameroff SP, O'Dea K, Peacock EE: Local anesthetics and wound healing. J Surg Res 1979; 27: 367-371

4. Moolenaar WH, Jalink K, van Corven EJ: Lysophosphangioten-sinidic acid: a bioactive phospholipid with growth factor-like properties. Rev Physiol Biochem Pharmacol 1992; 119: 48-65

5. Moolenaar WH: LPA: a novel lipid mediator with diverse biological actions. Trends Cell Biol 1994; 4: 213-219

6. van Corven EJ, Groenink A, Jalink K, Eichholtz T, Moolenaar WH: Lysophosphatidate-induced cell proliferation: identification and dissection of signaling pathways mediated by G proteins. Cell 1989; 59: 45-54

7. Fernhout BJH, Dijcks FA, Moolenaar WH, Ruigt GSF: Lysophosphatidic acid induces inward currents in Xenopus laevis oocytes; evidence for an extracellular site of action. Eur J Pharmacol 1992; 213: 313-315

8. Ferguson JE, Hanley MR: Phosphatidic acid and lysophosphatidic acid stimulate receptor-regulated membrane currents in the Xenopus laevis oocyte. Arch Biochem Biophys 1992; 297: 388-392

9. Postma FR, Jalink K, Hengeveld T, Bot AGM, Alblas J, Jonge HRD, Moolenaar WH: Serum-induced membrane depolarization in quiescent fibroblasts: activation of a chloride conductance through the G protein-coupled LPA receptor. EMBO J 1996; 15: 63-72

10. van Corven EJ, van Rijswijk A, Jalink K, van der Bend RL, van Blitterswijk WJ, Moolenaar WH: Mitogenic action of lysophosphatidic acid and phosphatidic acid on fibroblasts; dependence on acyl-chain length and inhibition by suramin. Biochem J 1992; 281: 163-169

11. Durieux ME: Lysophosphatidate signaling: cellular effects and molecular mechanisms. New York, Springer-Verlag/RG Landes, 1995

12. Tigyi G, Dyer DL, Matute C, Miledi R: A serum factor that activates the phosphotidylinositol phosphate signaling system in Xenopus oocytes. Proc Natl Acad Sci USA 1990; 87: $1521-1525$

13. Ma H, Blitzer RD, Healy EC, Premont RT, Landau EM, Iyengar R: Receptor-evoked $\mathrm{Cl}^{-}$current in Xenopus oocytes is mediated through a $\beta$-type phospholipase $C$; cloning a new form of the enzyme. J Biol Chem 1993; 268:19915-19918 
14. Durieux ME, Lynch KR: Signaling properties of lysophosphatidic acid. Trends Pharmacol Sci $1993 ; 14: 249-254$

15. Durieux ME: OoClamp: an IBM-compatible software system for the study of receptors expressed in Xenopus oocytes. Comput Meth Progr Biomed 1993; 41: 101-105

16. Durieux ME, Salafranca MN, Lynch KR, Moorman JR: Lysophosphatidic acid induces a pertussis toxin-sensitive $\mathrm{Ca}^{2+}$-activated $\mathrm{Cl}^{-}$current in Xenopus laevis oocytes. Am J Physiol 1992; 263: C896-C900

17. Miledi R, Parker I: Latencies of membrane currents evoked in Xenopus oocytes by receptor activation, inositol triphosphate and calcium. J Physiol 1989; 415: 189-210

18. Simon MF, Chap $H$, Douste-Blazy L: Human platelet aggregation induced by 1-alkyl-lysophosphatidic acid and its analogs: a new group of phospholipid mediators? Biochem Biophys Res Comm 1982; 108: 1743-1750

19. Tigyi G, Dyer DL, Miledi R: Lysophosphatidic acid possesses dual action in cell proliferation. Proc Natl Acad Sci USA 1994; 91:1908- 12

20. Tokumura A, Iimori M, Nishioka Y, Kitahara M, Sakashita M, Tanaka S: Lysophosphatidic acids induce proliferation of cultured vascular smooth muscle cells from rat aorta. Am J Physiol 1994; 267: C204-C210

21. Tigyi G, Hong L, Yakubu M, Parfenova H, Shibata M, Leffler CW: Lysophosphatidic acid alters cerebrovascular reactivity in piglets. Am J Physiol 1995; 268: H2048-H2055

22. Schumacher KA, Classen HG, Späth $M$ : Platelet aggregation evoked in vitro and in vivo by phosphatidic acids and lysoderivatives: identity with substances in aged serum (DAS). Thromb Haemost 1979; 42: 631-640

23. Agwu DE, McPhail LC, Sozzani S, Bass DA, McCall CE: Phosphatidic acid as a second messenger in human polymorphonuclear leukocytes; effects on activation of NADPH oxidase. J Clin Invest 1991; 88: 531-539

24. Jalink K, Moolenaar WH, van Duijn B: Lysophosphatidic acid is a chemoattractant for Dictyostelium discoideum amoebae. Proc Nad Acad Sci USA 1993; 90: 1857-1861

25. Dyer DL, Tigyi G, Miledi R: The effect of acfive serum albumin on PC12 cells: 1. Neurite retraction and activation of the phosphoinosifide second messenger system. Molec Brain Res 1992; 14: 293-301

26. Jalink K, Eichholtz T, Postma FR, van Corven EJ, Moolenaar WH: Lysophosphatidic acid induces neuronal shape changes via a novel, receptor mediated signaling pathway: similarity to thrombin action. Cell Growth and Differentiation 1993; 4: 247-255

27. Powell DM, Rodehaever GT, Foresman PA, Hankins CL, Bellian KT, Zimmer CA, Becker DG, Edlich RF: Damage to tissue defenses by EMLA cream. J Emerg Med 1991; 9: 205-209

28. Vasseur PB, Paul HA, Dybdal N, Crumley L: Effects of local anesthetics on healing of abdominal wounds in rabbits. Am J Vet Res 1984; 45: 2385-2388

29. Libelius $R$, Sonesson B, Stamenovic BA, Thesleff S: Denervation-like changes in skeletal muscle after treatment with local anesthetic (Marcaine). J Anat 1996; 106: 297-309

30. Odoom JA, Sturk A, Dokter PWC, Bovill JG, Ten Cate JW, Oosting J: The effects of bupivacaine and pipecoloxylidide on platelet function in vitro. Acta Anaesth Scand 1989; 33: 385-388

31. Kangasaho M: Effects of lidocaine, codeine and vadocaine hydrochloride on platelet aggregation in human platelet-rich plasma. Drug Res 1988; 38: 613-16

32. Gotta AW, Sullivan CA: Platelet aggregation and the pharmacology of local anesthetics. Drugs Exp Clin Res 1986; 12: 853-856 


\section{LOCAL ANESTHETICS AND LYSOPHOSPHATDATE SIGNALING}

33. Hou SM, Seaber AV, Urbaniak JR: Relief of blood induced arterial vasospasm by pharmacologic solutions. J Reconst Surg 1987; 3: 147-151

34. Giannotta SL, Kindt GW, Haar FL: Topical lidocaine in treatment of cerebral vasospasm. Surg Neurol 1975; 4: 13-416

35. Sundt TM, Onoirio BM, Meridedh J: Treatment of cerebral vasospasm from subarachnoid hemorrhage with isoproterenol and lidocaine hydrochloride. J Neurosurg 1973; 38: 557-560

36. Kindt GW, Hudson JS, Gosh HH, Gabrielsen TO: Relief of arterial vasospasm associated with cerebral aneurysms. Eur Neurol 1972; 8: 38-42

37. Covino BG, Vassallo HG: Local anesthetics. New York, Grune Stratton, 1976, pp 62-5

38. Butterworth JF, Strichartz GR: Molecular mechanisms of local anesthetics: a review. Anesthesiology 1996; 72: 711-734

39. Strichartz GR, Covino BG: Local anesthetics, Anesthesia. Edited by Miller RD. New York, Churchill Livingstone, 1990, pp 437-70

40. Rossi MA, Chan CK, Christensen JD, DeGuzman EJ, Durieux ME: Interactions between propofol and lipid mediator receptors: inhibition of lysophosphatidate signaling. Anesth Analg 1996; 83: 1090-1096 

CHAPTER 12

SUMMARY AND CONCLUSIONS / SAMENVATTING EN CONCLUSIES

Marcel E. Durieux 


\section{Summary and conclusions}

This thesis reports the development of a system for the study of molecular interactions between $G$ protein-coupled receptors and anesthetics. Although the main site of action for most intravenous and inhaled anesthetics appears to be the GABA $\mathrm{A}_{\mathrm{A}}$ receptor (ketamine's action on the NMDA glutamate receptor is an exception), the different effect and side effect profiles of these drugs is a result of their interactions with other systems. As discussed in Chapter 2, ion channels - both voltage-regulated and ligand-gated - have received most attention as sites of anesthetic action. Indeed, many channel types have been shown to be affected. The nicotinic acetylcholine receptor is an example of an ionotropic receptor significantly inhibited by low concentrations of anesthetics. Voltage-gated $\mathrm{Ca}$ and $\mathrm{K}$ channels are similarly inhibited by inhaled anesthetics. In contrast, the large superfamily of G protein-coupled receptors (GCRs) has received relatively little attention. Although scattered reports exist of anesthetic interactions with GCRs, only the effects on muscarinic acetylcholine signaling have been investigated in some detail. Part of this lack of investigative attention is due to technical difficulties in studying GCRs in isolation. Therefore, we adapted the Xenopus oocyte model, long used for the expression and cloning of GCRs, to the study of anesthetic interactions with these signaling molecules. Of particular interest would be GCRs for lipid mediators, as these would be likely targets for (lipophilic) anesthetics.

As reviewed in Chapter 4, the Xenopus oocyte has a number of compelling advantages for use in such studies. The frogs are easily maintained and oocytes are obtained with a simple procedure. In addition, once oocytes are adequately defolliculated, they are remarkably devoid of endogenous GCRs, with the exception of those described in the present thesis. GCRs can be expressed either by microinjection of RNA (extracted from tissue or prepared in vitro) or CDNA. Particularly $\mathrm{Ca}^{2+}$-signaling GCRs are easily studied, as the oocyte expresses an endogenous $\mathrm{Ca}^{2+}$-dependent $\mathrm{Cl}^{-}$channel, which is routinely used as a reporter for intracellular $\mathrm{Ca}^{2+}$ release. The results of the investigations in this thesis demonstrate that anesthetics of various classes can be applied without significantly modifying the behavior of the oocyte.

Chapters 5 and 6 describe our observations of two endogenous GCRs which are expressed consistently in oocytes: those for the phospholipid messengers lysophosphatidate (LPA) and sphingosine-1-phosphate (S1P). These two compounds are closely related structurally and functionally. As described in Chapter 3, LPA signaling has received much investigative attention recently. The compound has long be known to be an essential intermediate in phospholipid metabolism, but only in recent years has it become clear that it also acts as a signaling molecule. Its cellular effects are varied and dramatic. The compound acts as a contractile agent on various types of smooth muscle, including vascular smooth muscle. It is a potent mitogen for many types of fibroblasts. It activates platelets and - in turn - is released into the blood stream from activated platelets. It induces shape changes in a number of cell types, including neuronal cells. Its relevance to biological systems is shown by the fact that LPA acts as a chemoattractant in a species as far removed from mammals as Dictyostelium discoideum. A variety of studies over the past ten years have provided detailed insight into the cellular mechanism of action of LPA. Although a membrane receptor has not yet been cloned convincingly, biochemical evidence strongly supports its existence. LPA binding to this receptor leads to intracellular activation of several $G$ proteins, inducing $\mathbb{P}_{3}$ and DAG generation, as well as decreases in cAMP levels. The mitogenic and cytoskeletal actions of the compound are mediated by small cytoplasmic $G$ proteins and the MAP kinase cascade. Thus, LPA is a molecule of significant interest. Some of its actions may be 
relevant in the perioperative period, and anesthetic effects on LPA signaling are therefore worthy of investigation. As in addition the compound forms a good model for lipid mediator signaling in general, and the receptor is endogenously expressed in oocytes, we decided to study the effects of several classes of anesthetics on LPA signaling.

Chapter 5 reports our finding of the endogenous LPA response in Xenopus oocytes. LPA induced transient dose-dependent currents in uninjected cells. The response was found to be highly specific, as related compounds (phosphatidic acid, lysophosphatidylcholine, lysophosphatidylserine) were without effect. Intracellular LPA application did not induce intracellular $\mathrm{Ca}^{2+}$ release, strongly suggesting an extracellular site of action. In addition, the response to LPA could be inhibited by incubation in pertussis toxin, indicating $G$ protein involvement. We could establish that the induced currents were $\mathrm{Ca}^{2+}$-activated $\mathrm{Cl}^{-}$currents, as they were abolished by intracellular injection of EGTA, and the reversal potential became more positive at lower extracellular $\mathrm{Cl}^{-}$concentrations. Suramin, which had been shown to inhibit LPA responses in other systems, blocked the current. Hence, we concluded that this novel oocyte response to LPA was mediated by a specific membrane receptor linked to a pertussis toxin-sensitive $G$ protein.

When searching for related responses in oocytes, we tested S1P, and found it also to induce currents. As detailed in Chapter 6 , these currents were similarly $\mathrm{Ca}^{2+}$-activated $\mathrm{Cl}^{2}$ currents, virtually indistinguishable from those induced by LPA. Intracellular injection of S1P was without effect, as was extracellular application of several compounds structurally related to S1P (sphingosine, sphingosylphosphorylcholine and $\mathrm{N}, \mathrm{N}$-dimethylsphingosine). In order to investigate if S1P and LPA might signal through the same receptor, we employed cross-desensitization, and found that LPA and S1P cross-desensitized completely. Both responses were inhibited by suramin and dithiothreitol. Thus, this suggests the existence of a single receptor for the two compounds. We were able to elicit responses to both LPA and S1P in HEK293 fibroblasts, but to neither of the compounds in K562 cells. However, no cross-desensitization between the compounds was observed in HEK 293 cells.

As standard electrophysiology systems are not designed to function effectively with the long time courses and large currents induced by GCR signaling in oocytes, we developed a software system specifically geared to this function, as described in Chapter 7. OoClamp, as it is called, is a MS-DOS based package for the acquisition, analysis and storage of data from GCR studies in Xenopus oocytes. The system is designed to provide standardization of test conditions, rapid, on-line analysis of data, and self-documentation and compact storage of data files. All system settings are optimized for use with the Xenopus expression system. This system has been used for data acquisition in all subsequent studies reported in this thesis.

In the course of these investigations, we discovered an additional endogenous oocyte response: a current induced by trypsin. As described in Chapter 8, trypsin induces $\mathrm{Ca}^{2+}$-activated

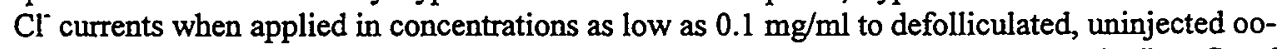
cytes. The response is dose-dependent and specific, as other proteases (chymotrypsin, Lys-C and Arg-C) or trypsin pretreated with soybean trypsin inhibitor, were without effect. The response was due to an extracellular site of action, as microinjected trypsin did not induce currents. We also tested if the trypsin response could be due to proteolytic activation of LPA signaling, but found this not to be the case.

After these initial studies of oocyte physiology, we studied the effects of three classes of anesthetics on LPA signaling in oocytes. Chapter 9 reports the effects of propofol, a highly lipophilic intravenous anesthetic known to have its primary site of action on the $\mathrm{GABA}_{\mathrm{A}}$ receptor. Propofol in Intralipid ${ }^{\otimes}$ dose-dependently inhibited LPA signaling $\left(\mathrm{IC}_{50} 5.38 \mu \mathrm{M}\right)$. Propofol 28 
$\mu \mathrm{M}$ inhibited LPA by more than $80 \%$. Intralipid ${ }^{\otimes}(0.01 \%)$ was without effect. To ascertain that intracellular signaling pathways and the $\mathrm{Ca}^{2+}$-activated $\mathrm{Cl}^{-}$channel were not affected by propofol, we tested the effects of propofol on currents induced by methylcholine in oocytes expressing $\mathrm{ml}$ muscarinic acetylcholine receptors. No inhibition was observed. As both receptors share the same intracellular signaling pathway, we concluded that clinically relevant concentrations of propofol inhibit LPA signaling, acting most likely on the receptor or the associated $G$ protein. Thus, lipophilic anesthetics indeed interfere significantly with signaling through lipid mediator receptors.

Chapter 10 describes the effects of two volatile anesthetics, halothane and isoflurane, on LPA signaling. We found halothane to inhibit LPA signaling in a dose-dependent manner $\left(\mathrm{IC}_{50}\right.$ $0.23 \mathrm{mM}$ ). Halothane $0.34 \mathrm{mM}$ inhibited responses to LPA virtually completely. This effect was fully reversible. As we had shown previously that halothane inhibits functioning of muscarinic receptors, we used instead the $A T_{1 A}$ angiotensin receptor to test for anesthetic effects on the shared intracellular signaling pathway. Halothane, even at the highest concentrations tested, was without effect on angiotensin signaling. To assure that both receptors signaled through the same pathway, we microinjected oocytes with heparin, an $\mathbb{P}_{3}$ receptor blocker. Responses to both LPA and angiotensin were inhibited by this treatment, confirming that both receptors signal through $\mathrm{IP}_{3}$. Currents elicited by microinjection of $\mathrm{IP}_{3}$ into oocytes were not affected by halothane. Together, these findings confirm that the effect of halothane is proximal in the signaling pathway, most likely at the LPA receptor or G protein. In contrast to halothane, isoflurane was without effect on LPA signaling. Thus, volatile anesthetics can interfere with lipid mediator signaling, but the action is specific.

Finally, we studied the effect of two local anesthetics, lidocaine and bupivacaine, on LPA signaling, as described in Chapter 11 . This study was of particular relevance as a role for LPA in wound healing seems likely, and local anesthetics have been shown to impair wound healing. Both compounds inhibited LPA signaling (IC $_{50} 29.9 \mathrm{mM}$ for lidocaine and $4.5 \mathrm{mM}$ for bupivacaine - concentrations reached after local anesthetic injection around wounds). At high local anesthetic concentrations, virtually compete inhibition of LPA signaling was observed. The effect of bupivacaine was completely reversible, whereas lidocaine appeared to have a partially irreversible effect. Both compounds were without effect on angiotensin or $\mathrm{IP}_{3}$ signaling.

Taken together, these studies show that the Xenopus oocytes is a flexible model for the study of anesthetic actions on GCR signaling, and that selected members of the three main classes of anesthetics interfere with at least one lipid mediator receptor.

Further studies suggest themselves. First, more detailed localization of the site of action is useful. We have now been able to induce $\mathrm{Ca}^{2+}$-activated $\mathrm{Cl}^{-}$currents in oocytes by microinjection of the non-hydrolyzable GTP analog GTPyS, and have found that halothane is without effect on these currents. Thus, the site of action of halothane is more proximal than the G protein effector domain, and therefore either involves the receptor, the receptor- $G$ protein interface or early steps in G protein signaling (such as GDP-GTP exchange). We have obtained similar results have been obtained with local anesthetics. We have shown in addition that charged local anesthetics inhibit the LPA receptor at an intracellular site, using the non-permeable, permanently charged lidocaine analog QX314. Permanently uncharged compounds, exemplified by benzocaine, can also block LPA signaling, and as they interact with QX314 in a synergistic manner, the presence of two binding sites is suggested. It would be of great interest to test stereoisomers of some of the anesthetics, as a stereoselective effect would suggest a protein (receptor) site of action. Such studies are now in progress with the isomers of ropivacaine. 
In addition, it is important to extent these results to other lipid mediator receptors. We have chosen the thromboxane $A_{2}\left(T_{X A_{2}}\right)$ receptor because of its relevance in vasoconstriction and platelet aggregation, effects similar to those of LPA. We found both general anesthetics and local anesthetics inhibit to $\mathrm{TXA}_{2}$ signaling. Both isoflurane and halothane inhibit signaling, but competition studies suggest different site of action. This is in agreement with data obtained at other receptors, as discussed in Chapter 3 . The effect of local anesthetics is profoundly timedependent. After several hours incubation, concentrations of lidocaine and bupivacaine achieved in plasma during epidural anesthesia are found to inhibit $\mathrm{TXA}_{2}$ signaling significantly. The mechanism of this delayed effect is under study.

It is also important to confirm findings obtained in a highly isolated model such as the oocyte to receptors in a more native environment. Therefore, studies of the effects of anesthetics on, e.g. LPA-induced platelet aggregation should be performed.

The number of lipid mediator receptors is large, and many of them play important roles during injury and repair. Thus, their functioning is of great importance during the perioperative period. Our data suggest that they may be targets for anesthetic action, and that anesthetics of several classes can significantly limit their functioning. This may have consequences for the bodily response during and after surgery, and a full understanding of these anesthetic-receptor interactions and their consequences is therefore warranted.

\section{SAMENVATTING EN CONCLUSIES}

Deze dissertatie beschrijft de ontwikkeling van een systeem voor de studie van moleculaire interacties tussen G-eiwit gekoppelde receptoren en anesthetica. Hoewel het belangrijkste effect voor de meeste intraveneus en per inhalatie toegediende anesthetica de $\mathrm{GABA}_{\mathrm{A}}$ receptor schijnt te zijn (het effect van ketamine op de NMDA giutamaat receptor is een uitzondering), zijn de verschillende werkings- en bijwerkingsprofielen van deze geneesmiddelen een gevolg van interacties met andere systemen. Als beschreven in Hoofdstuk 2, hebben ionenkanalen - zowel potentiaal-gestuurd als ligand-gestuurd - de meeste aandacht gekregen als werkingsplaats van anesthetica. Van veel soorten kanalen is inderdaad aangetoond dat ze beinvloed worden. De nicotinische acetylcholine receptor is een voorbeeld van een ionotropische receptor die in aanzienlijke mate geremd wordt door lage concentraties inhalatieanesthetica. Potentiaal-gestuurde $\mathrm{Ca}$ en $\mathrm{K}$ kanalen worden op gelijke wijze geremd. De grote superfamilie van $\mathrm{G}$ eiwit-gekoppelde receptoren (GCRs) heeft in tegenstelling relatief weinig aandacht gekregen. Hoewel verspreide rapporten bestaan over interacties tussen anesthetica en GCRs zijn alleen de effecten op muscarinische acetylcholine signalering in enig detail bestudeerd. Een deel van dit gebrek aan onderzoeksaandacht is het gevolg van de technische moeilijkheden in het bestuderen van GCRs in isolatie. Om die reden hebben wij het Xenopus oocyt model, reeds lang in gebruik voor expressie en clonering van GCRs, aangepast voor de studie van anesthetica interacties met deze signaalmoleculen. Van speciaal belang zouden zijn de GCRs voor lipiedmediatoren, aangezien deze waarschijnlijke doelen zouden vormen voor (lipofiele) anesthetica.

Als beschreven in Hoofdstuk 4, hebben Xenopus oocyten een aantal overtuigende voordelen voor het gebruik in dergelijke studies. De kikkers zijn makkelijk in onderhoud en oocyten zijn te verkrijgen met een eenvoudige ingreep. Bovendien zijn oocyten, eenmaal voldoende gedefolliculeerd, opmerkelijk viij van endogene GCRs, met als uitzondering degenen beschreven in deze dissertatie. GCRs kunnen worden geexprimeerd hetzij door microinjectie van RNA (ge- 
extraheerd uit weefsel of in vitro geprepareerd) of cDNA. Met name GCRs die signaleren via $\mathrm{Ca}^{2+}$ zijn makkelijk te bestuderen, omdat de oocyt een endogeen $\mathrm{Ca}^{2+}$-afhankelijk $\mathrm{Cl}^{-}$kanaal bezit dat routinematig gebruikt wordt als een reporter voor intracellulair vrijgemaakt $\mathrm{Ca}^{2+}$. De resultaten van de onderzoekingen in deze dissertatie tonen aan dat anesthetica van verschillende klassen kunnen worden toegediend zonder de eigenschappen van de oocyt noemenswaardig te beinvloeden.

Hoofdstuk 5 en 6 beschrijven onze waarnemingen betreffende twee endogene GCRs die consistent in oocyten geexprimeerd zijn: voor de fosfolipide signaalmoleculen lysofosfatidaat (LPA) en sfingosine-1-fosfaat (S1P). Deze twee substanties zijn elkaar sterk verwant, zowel structureel als functioneel. Als beschreven in Hoofdstuk 3 is LPA signalering de laatste tijd onderwerp van veel onderzoeksinteresse. Het molecuul is lang bekend als een essentiële tussenstap in fosfolipied metabolisme, maar slechts in de afgelopen jaren is duidelijk geworden dat het ook functioneert als een signaal molecuul. Het werkt als contractiel agonist op verschillende soorten glad spierweefsel, inclusief vaatspierweefsel. Het is een krachtig mitogeen voor vele typen fibroblast. Het activeert thrombocyten en - anderzijds - wordt door geactiveerde thrombocyten in de bloedbaan vrijgemaakt. Het induceert vormveranderingen in een aantal celtypen, waaronder zenuwcellen. Het belang voor biologische systemen wordt duidelijk uit het feit dat LPA als chemoattractant functioneert in een soort zo ver verwijderd van zoogdieren als Dictyostelium discoideum. Een groot aantal studies over de afgelopen tien jaar heeft gedetailleerd inzicht opgeleverd in de cellulaire werkingsmechanismen van LPA. Hoewel een membraanreceptor nog niet overtuigend is gekloneerd wordt zijn bestaan krachtig gestaafd door biochemische bevindingen.

Binding van LPA met zijn receptor leidt tot intracellulaire activering van verschillende $G$ eiwitten, waardoor $\mathrm{IP}_{3}$ en DAG gegenereerd worden, en cAMP niveaus dalen. De mitogene en cytoskelet effecten van LPA worden gemedieerd door kleine cytoplasmatische $G$ eiwitten en de MAP kinase keten. LPA is derhalve een molecule met aanmerkelijke interesse. Een aantal van zijn effecten zijn mogelijkerwijze relevant in de perioperatieve periode, en het is daarom relevant om effecten van anesthetica op LPA signalering te bestuderen. Aangezien de substantie bovendien een goed model vormt voor lipied mediator signalering in het algemeen, en aangezien de receptor endogeen geexprimeerd is in oocyten, besloten wij de effecten van verschillende klassen anesthetica op LPA signalering te bestuderen.

Hoofdstuk 5 rapporteert onze bevindingen omtrent de endogene LPA respons in Xenopus oocyten. LPA veroorzaakt tijdelijke, dosis-afhankelijke ionenstromen in niet-geinjecteerde cellen. De response was uiterst specifiek, aangezien verwante stoffen (fosfatidaatzuur, lysofosfatidylcholine, lysofosfatidylserine) zonder effect waren. Intracellulaire toediening van LPA maakte geen intracellulair $\mathrm{Ca}^{2+}$ vrij, hetgeen sterk wijst op een extracellulaire werkingsplaats. De respons op LPA kon bovendien worden onderdrukt door incubatie in pertussis toxine, wijzend op een rol voor $\mathrm{G}$ eiwitten. Wij konden aantonen dat de geinduceerde stromen $\mathrm{Ca}^{2+}$-geactiveerde $\mathrm{Cl}^{-}$ stromen waren, aangezien ze onderdrukt werden door intracellulaire injectie van EGTA, en aangezien de omkeringspotentiaal meer positief werd met lagere extracellulaire $\mathrm{Cl}^{-}$concentraties. Suramine, hetgeen LPA effecten in andere systemen onderdrukt, verminderde de stromen. Wij concludeerden dat deze nieuwe oocyt respons op LPA gemedieerd wordt door een specifieke membraan receptor gekoppeld met een pertussis toxine-gevoelig $\mathrm{G}$ eiwit.

Op zoek naar vergelijkbare reacties in oocyten testten wij S1P, en vonden dat het eveneens stromen induceerde. Als beschreven in Hoofdstuk 6 waren deze stromen eveneens $\mathrm{Ca}^{2+}$ geinduceerde $\mathrm{Cl}^{-}$stromen, vrijwel niet te onderscheiden van degenen geinduceerd door LPA. Intracellulaire injectie van S1P was zonder effect, evenals extracellulaire toediening van verschil- 
lende structureel aan S1P verwante stoffen (sfingosine, sfingosylfosforylcholine en N,Ndimethylsfingosine). Om te onderzoeken of S1P en LPA via dezelfde receptor signaleren testten we kruisdesensitisatie, en vonden dat LPA en S1P volledig kruisdesensitiseren. Beide responsen werden onderdrukt door suramine en dithiothreitol. Dit suggereert derhalve het bestaan van een enkele receptor voor beide substanties. We waren in staat reacties op LPA en S1P te verkrijgen in HEK293 fibroblasten, maar op geen van beide stoffen in $\mathrm{K} 562$ cellen. Er werd evenwel geen kruisdesensitisatie waargenomen in HEK293 cellen.

Aangezien de gebruikelijke electrofysiologie systemen niet ontworpen zijn om effectief te functioneren met de lange tijdsduren en grote stromen die door GCRs in oocyten geinduceerd worden, ontwikkelden we een software systeem specifiek ontworpen voor dit doel, als beschreven in Hoofdstuk 7. OoClamp, zoals het genoemd is, is een MS-DOS-gebaseerd pakket voor opname, analyse en opslag van gegevens verkregen met GCR studies in Xenopus oocyten. Het systeem is ontworpen om standaardisatie van test condities, snelle, on-line data analyse, en zelfdocumentatie en compacte gegevensopslag te verschaffen. Alle systeem parameters zijn geoptimaliseerd voor gebruik met het oocyt expressie systeem. Dit systeem is gebruikt voor data opname in alle volgende studies beschreven in deze dissertatie.

In de loop van deze onderzoekingen ontdekten we nog een endogene respons van de oocyt: een stroom geinduceerd door trypsine. Als beschreven in Hoofdstuk 8 induceert trypsine, wanneer toegediend op gedefolliculeerde, ongeinjecteerde oocyten in concentraties zo laag als $0.1 \mathrm{mg} / \mathrm{ml}$, een $\mathrm{Ca}^{2+}$-geactiveerde $\mathrm{Cl}^{-}$stroom. De respons is dosis-afhankelijk en specifiek, aangezien andere proteasen (chymotrypsine, Lys-C en Arg-C), zowel als trypsine voorbehandeld met soja trypsine inhibitor, zonder effect waren. De respons was het gevolg van een extracellulaire werkingsplaats, aangezien gemicroinjecteerd trypsine geen stromen induceerde. We testten ook of de trypsine respons een gevolg kon zijn van proteolytische activering van LPA signalering, maar dit bleek niet het geval.

$\mathrm{Na}$ deze voorbereidende studies van oocyt fysiologie bestudeerden we de effecten van drie klassen anesthetica op LPA signalering in oocyten. Hoofdstuk 9 rapporteert de effecten van propofol, een zeer lipofiel intraveneus anestheticum met zijn primaire werkingsplaats op de GABA $_{\mathrm{A}}$ receptor. Propofol in Intralipid ${ }^{\oplus}$ onderdrukte LPA signalering op dosis-afhankelijke wijze $\left(\mathrm{IC}_{50} 5.38 \mu \mathrm{M}\right)$. Propofol $28 \mu \mathrm{M}$ onderdrukte LPA signalering meer dan $80 \%$. Intralipid ${ }^{*}$ $(0.01 \%)$ alleen was zonder effect. Om zeker te zijn dat intracellulaire signaalwegen en het $\mathrm{Ca}^{2+}$. geactiveerde $\mathrm{Cl}^{-}$kanaal niet beinloed waren door propofol testten we het effect van propofol op stromen geinduceerd door methylcholine in oocyten die de $\mathrm{ml}$ muscarinische acetylcholine receptor exprimeerden. Er werd geen inhibitie waargenomen. Aangezien beide receptoren dezelfde intracellulaire signaalketen delen concludeerden wij dat klinisch relevante concentraties propofol LPA signalering onderdrukken, waarschijnlijk werkend op de receptor of het geassocieerde $G$ eiwit. Lipofiele anesthetica interfereren derhalve inderdaad aanzienlijk met receptoren voor lipied mediatoren.

Hoofdstuk 10 beschrijft de effecten van twee inhalatieanesthetica, halothaan en isofluraan, op LPA signalering. We vonden dat halothaan LPA signalering onderdrukte op dosisafhankelijke wijze $\left(\mathrm{IC}_{50} 0.23 \mathrm{mM}\right)$. Halothaan $0.34 \mathrm{mM}$ onderdrukte LPA responsen vrijwel compleet. Dit effect was volledig reversibel. Aangezien we eerder aangetoond hadden dat halothaan de functie van muscarinische receptoren onderdrukt, gebruikten we de $\mathrm{AT}_{1 \mathrm{~A}}$ angiotensine receptor om effecten van het anestheticum op de intracellulaire signaalketen te testen. Halothaan was zelfs in de hoogste concentraties zonder effect op angiotensine signalering. Om er zeker van te zijn dat beide receptoren over dezelfde keten signaleren microinjecteerden we oocyten met 
heparine, een $\mathrm{PP}_{3}$ receptor antagonist. Responsen op zowel LPA als angiotensine werden door deze behandeling onderdrukt, aantonend dat beide receptoren via $\mathrm{IP}_{3}$ signaleren. Stromen geinduceerd door microinjectie van $\mathrm{IP}_{3}$ in oocyten werden niet beinvloed door halothaan. Tezamen duiden deze bevindingen er op dat het effect van halothaan proximaal in de signaalketen plaatsvindt, meest waarschijnlijk op de LPA receptor of G eiwit. Isofluraan, in tegenstelling tot halothaan, was zonder effect op LPA signalering. Volatiele anesthetica kunnen derhalve interfereren met lipied mediator signalering, maar hun effecten zijn specifiek.

Tenslotte onderzochten we de effecten van twee lokaalanesthetica, lidocaine en bupivacaine, op LPA signalering, als beschreven in Hoofdstuk 11. Deze studie was van bijzonder belang aangezien een rol voor LPA in wondheling waarschijnlijk lijkt, en aangezien is aangetoond dat lokaalanesthetica wondheling nadelig beinvloeden. Beide anesthetica onderdrukten LPA signalering $\left(\mathrm{IC}_{50} 29.9 \mathrm{mM}\right.$ voor lidocaine en $4.5 \mathrm{mM}$ voor bupivacaine - concentraties die bereikt worden na injectie van lokaalanesthetica rond wonden). Met hoge concentraties lokaalanestheticum werd vrijwel volledige onderdrukking van LPA signalering waargenomen. Het effect van bupivacaine was volleding reversibel, maar lidocaine had een deels irreversibel effect. Beide stoffen waren zonder effect op angiotensine of $\mathrm{IP}_{3}$ signalering.

Tezamen tonen deze studies aan dat Xenopus oocyten een flexibel model vormen voor de studie van de effecten van anesthetica op GCR signalering, en dat sommige leden van de drie grote klassen van anesthetica interfereren met op zijn minst één lipied mediator receptor.

Verdere studies zijn mogelijk. In de eerste plaats zou meer gedetailleerde localisatie van de werkingsplaats nuttig zijn. Wij zijn er nu in geslaagd om $\mathrm{Ca}^{2+}$-geactiveerde $\mathrm{Cl}^{-}$stromen te induceren in oocyten door microinjectie van het niet-hydrolyseerbare GTP analogon GTP $\gamma$, en we hebben gevonden dat halothane zonder effect is op deze stromen. De werkingsplaats van halothaan is derhalve stroomopwaarts van het $G$ eiwit, en omvat dus de receptor of de receptor- $G$ protein interface. We verkregen vergelijkbare resultaten met lokaalanesthetica. Bovendien hebben we aangetoond, gebruikmakend van het niet-permeabele, permanent geladen lidocaine analogon QX314, dat positief geladen lokaalanesthetica de LPA receptor intracellulair beinvloeden. Permanent ongeladen lokaalanesthetica, bijvoorbeeld benzocaine, blokkeren LPA signalering eveneens, en aangezien ze synergistisch werken met QX314, is de aanwezigheid van twee bindingsplaatsen mogelijk. Het zou zeer interessant zijn om stereoisomeren van enkele van deze anesthetica te testen, aangezien een stereoselectief effect een eiwit (receptor) werkingsplaats zou suggereren. Dergelijke studies zijn nu in uitvoering met de stereoisomeren van ropivacaine.

Het is bovendien van belang deze resultaten uit te breiden tot andere lipid mediator receptoren. Wij hebben de thromboxaan $\mathrm{A}_{2}\left(\mathrm{TXA}_{2}\right)$ receptor gekozen vanwege zijn relevantie in vasoconstrictie en thrombocytenaggregatie, effecten vergelijkbaar met die van LPA. We vonden dat algehele anesthetica zowel als lokaalanesthetica TXA 2 signalering onderdrukken. Zowel halothaan als isofluraan onderdrukken signalering, maar competitie studies suggereren verschillende werkingsplaatsen. Dit is in overeenstemming met gegevens van andere receptoren, als besproken in Hoofdstuk 3. Het effect van lokaalanesthetica is buitengewoon tijdafhankelijk. Na enkele uren incubatie onderdrukken concentraties van lidocaine en bupivacaine als aanwezig in plasma tijdens epiduraalanesthesie TXA $\mathrm{TX}_{2}$ signalering aanzienlijk. Het mechanisme voor dit vertraagde effect is onder studie.

Het is ook van belang om de gegevens verkregen in een zeer geisoleerd model zoals de oocyt te bevestigen in een meer fysiologisch model. Studies van het effect van anesthetica op bv. LPA-geinduceerde thrombocytenaggregatie zijn daarom aangewezen. 
Het aantal lipied mediator receptoren is groot, en vele spelen een belangrijke rol tijdens weefselbeschadiging en reparatie. Hun functie is dus van groot belang tijdens de perioperatieve periode. Onze gegevens suggereren dat zij een doel vormen voor anesthetica, en dat anesthetica van verschillende klassen hun functie aanzienlijk kunnen inperken. Dit kan gevolgen hebben voor de reacties van het lichaam tijdens en na operatieve ingrepen, en een volledig begrip van deze anesthetica-receptor interacties en hun consequenties is derhalve van belang. 


\section{ACKNOWLEDGMENTS}

The studies reported in this thesis were carried out at the University of Virgina, Charlottesville, VA, USA, in the Departments of Anesthesiology, Pharmacology, and Cardiology, between 1991 and 1997.

I first wish to thank my co-workers who are co-authors on the papers presented here. In no particular order: Kevin Lynch, Randall Moorman, Mina Salafranca, Steve Carlisle, Adrian Rossi, Carrie Chan, Jared Christensen, Emily deGuzman, and Gregor Nietgen.

I am most grateful to Simon de Lange, for his continued support in this trans-oceanic undertaking.

I also wish to express my thanks to Robert Epstein and Jim Garrison, Chairs of Anesthesiology and Pharmacology, respectively, during the time that these studies were performed. Their support has been immensely helpful.

I thank John Roord for stimulating me to undertake this project.

I am deeply indebted to Patty Jenkins, who spent a great deal of her time in secretarial support of this thesis.

Sincere thanks go to Erik Hewlett and the Virginia Diabetes Center for supplying pertussis toxin; Wouter Moolenaar for stimulating our thinking about LPA, and providing us with one of his manuscripts prior to publication; Jim Lechleiter and Patricia Camacho for valuable discussions about oocyte technique; Ed John for help with oocyte handling and RNA preparation; Tom Thompson for raising the question whether LPA and SIP might act at the same site; Tom Picarriello for assistance with thin-layer chromatography and nuclear magnetic resonance; Dr. Bergsma for the COS-1 cell line; Craig Slingluff for the K-562 cell line; Dr. Bonner for the muscarinic acetylcholine receptor $\mathrm{cDNA}$; and Joe Pancrazio for his continued encouragement in the development of OoClamp.

The studies were financially supportedy by the National Institutes of Health, the American Heart Association, the American Canter Society, and the Department of Anesthesiology at the University of Virginia.

Finally, my gratitude goes to all those members of the Departments of Pharmacology and Anesthesiology for their willingness to share their time and knowledge with me. 


\section{LIST OF PUBLICATIONS}

\section{Original articles:}

1. Longnecker DE, Durieux ME, Donovan KR, Miller ED Jr, Peach MJ: Saralasin dilates arterioles in SHR but not WKY rats. Hypertension 1984; 6: I106-I 10

2. Seyde WC, Durieux ME, Longnecker DE: The hemodynamic response to isoflurane is altered in genetically hypertensive (SHR), as compared with normotensive (WKY), rats. Anesthesiology 1987; 66: 798-804

3. Durieux ME, Sperry RJ, Longnecker DE: Effects of hypoxemia on regional blood flows during anesthesia with halothane, enflurane, or isoflurane. Anesthesiology 1992; 76: 402-408

4. Durieux ME, Salafranca MN, Lynch KR, Moorman JR: Lysophosphatidic acid induces a pertussis toxin-sensitive $\mathrm{Ca}^{2+}$-activated $\mathrm{Cl}^{-}$-current in Xenopus oocytes. Am J Physiol 1992; 263: C896-C900

5. Moorman JR, Palmer CJ, John JE II, Durieux ME, Jones LR: Phospholemman expression induces a hyperpolarization-activated chloride current in Xenopus oocytes. J Biol Chem 1992; 267: 14551-14554

6. Sessa WC, Harrison JK, Barber CM, Zeng D, Durieux ME, D'Angelo DD, Lynch KR, Peach MJ: Molecular cloning and expression of a cDNA encoding endothelial nitric oxide synthase. J Biol Chem 1992; 267: 15274-15276

7. Sperry RJ, Monk CR, Durieux ME, Longnecker DE: The influence of hemorrhage on organ perfusion during deliberate hypotension in rats. Anesthesiology 1992; 77: 1171-1177

8. Durieux ME, Carlisle SJ, Salafranca MN, Lynch KR: Responses to sphingosine-1-phosphate in X. laevis oocytes: similarities with lysophosphatidic acid signaling. Am J Physiol 1993; 264: C1360-C1364

9. Durieux ME: OoClamp, an IBM-compatible software system for electrophysiologic receptor studies in Xenopus oocytes. Computer Meth Prog Biomed 1993; 41: 101-105

10. Durieux ME, Salafranca MN, Lynch KR: Trypsin induces $\mathrm{Ca}^{2+}$-activated $\mathrm{Cl}^{-}$currents in $X$. laevis oocytes. FEBS Lett 1994; 377: 235-238

11. Durieux ME: Halothane inhibits signaling through $\mathrm{m} 1$ muscarinic receptors expressed in Xenopus oocytes. Anesthesiology 1995; 82: 174-182

12. Durieux ME: Inhibition by ketamine of muscarinic acetylcholine receptor function. Anesth Analg 1995; 81: 57-62

13. Rossi MA, Chan CK, Christensen JD, DeGuzman EJ, Durieux ME: Interactions between propofol and lipid mediator receptors: inhibition of lysophosphatidate signaling. Anesth Analg 1996; 83: 1090-1096

14. Sitzman BT, Rich GF, Rockwell JJ, Leisure GS, Durieux ME, DiFazio CA: Local anesthetic administration for awake direct laryngoscopy: are glossopharyngeal nerve blocks superior? Anesthesiology 1997; 86: 34-40

15. Chan CK, Durieux ME: Differential inhibition of lysophosphatidate signaling by volatile anesthetics. Anesthesiology 1997; 86:660-669

16. Nietgen GW, Chan CK, Durieux ME: Inhibition of lysophosphatidate signaling by lidocaine and bupivacaine. Anesthesiology 1997; 86:1112-1119

17. Durieux ME, Nietgen GW: Synergistic inhibition of muscarinic signaling by ketamine stereoisomers and the preservative benzethonium chloride. Anesthesiology 1997; 86:13261333. 
18. Bavbek M, Kamiryo T, Durieux ME: The role of lysophosphatidic acid in radiation injury: a pilot study. Turk J Neurosurg 1997; 7:20-23

19. Hönemann CH, Nietgen GW, Podranski P, Chan CK, Durieux ME: Influence of volatile anesthetics on thromboxane $A_{2}$ signaling. Anesthesiology 1998; 88: 440-451

20. Hooks SB, Ragan SP, Hopper DW, Hönemann CW, Durieux ME, Macdonald TL, Lynch KR: Characterization of a subtype-selective lysophosphatidic acid mimetic. Molec Pharmacol 1998; 53: 188-194

21. Hönemann CW, Washington JM, Hönemann MC, Nietgen GW, Durieux ME: Partition coefficients of volatile anesthetics in aqueous solutions at various temperatures. Anesthesiology 1998; 89: 1032-1035

22. Nietgen GW, Hönemann CW, Kamatchi GW, Chan CK, Durieux ME: Differential effects of isoflurane and desflurane on muscarinic acetylcholine signaling. Br J Anaesth 1998; 81: 569577

23. Sullivan LM, Hönemann CW, Arledge JA, Durieux ME: Synergistic inhibition of lysophosphatidic acid signaling by charged and uncharged local anesthetics. Anesth Analg (in press)

24. Kamatchi GL, Chan CK, Durieux ME, Lynch C III: Volatile anesthetic interactions with neuronal Ca channels expressed recombinantly in Xenopus oocytes. Brain Res (in press)

25. Kohrs R, Hönemann CW, Feirer N, Durieux ME: Bupivacaine inhibits whole blood coagulation: interactions with thromboxane signaling. (submitted)

26. Hönemann CW, Wong A, Arledge JAM, Durieux ME: Prolonged ethanol exposure enhances signaling through muscarinic receptors expressed by cRNA injection in Xenopus oocytes: implications for mechanism of action. Alcoholism: Clin Exp Res (in press)

27. Hahnenkamp K, Hönemann CW, Fischer LG, Durieux ME, Muehlendyck H, Braun U: Effect of different anesthetic regimens on the oculo-cardiac reflex during pediatric strabismus surgery. (submitted)

28. Hönemann CW, Hahnenkamp K, Durieux ME, Baum JA: Minimal flow anesthesia with controlled ventilation: comparison of laryngeal mask airway and endotracheal tube. (submitted)

\section{Abstracts (selected):}

1. Monk CR, Sperry RJ, Durieux ME, Walker MS, Longnecker DE: Regional cerebral blood flow in rats: induced hypotension with isoflurane, sodium nitroprusside, or 2-chloroadenosine. Anesthesiology 1987; 67: A577

2. Monk CR, Sperry RJ, Durieux ME, Walker MS, Longnecker DE: The regional hemodynamic effects of induced hypotension with isoflurane, sodium nitroprusside, or 2-chloroadenosine. Anesthesiology 1987; 67: A34

3. Sperry RJ, Monk CR, Durieux ME, Walker MS, Longnecker DE: Regional cerebral blood flows during deliberate hypotension complicated by hemorrhage. Anesthesiology 1987; 67: A575

4. Durieux ME, Monk CR, Sperry RJ, Matthern GE, Longnecker DE: Labetalol preserves blood flows to vital organs during deliberate hypotension induced by isoflurane. Anesthesiology 1988; 69: A899

5. Durieux ME, Monk CR, Sperry RJ, Matthern GE, Longnecker DE: Regional cerebral blood flow during hypoxemia in rats anesthetized with halothane, enflurane or isoflurane. Anesthesiology 1988; 69: A624 
6. Moorman JR, Palmer CJ, John JE III, Salafranca MN, Durieux ME, Jones LR: Functional expression of a novel cardiac chloride channel in Xenopus oocytes. Circulation 1992; 86: I76

7. Carlisle SJ, Durieux ME, Salafranca MN, Lynch KR: Responses to sphingosine-1-phosphate in $X$. laevis oocytes: similarities with lysophosphatidic acid signaling. American Cancer Society, 1993 Virginia Annual Meeting Proceedings

8. Durieux ME, Salafranca $\mathrm{N}$ : Halothane inhibits signaling through $\mathrm{M}_{1}$ muscarinic receptors expressed in Xenopus oocytes. Anesthesiology 1993; 78: A734

9. Durieux ME: Halothane profoundly inhibits lysophosphatidate signaling. Anesthesiology 1994; 81: A764

10. Durieux ME: Interactions between ketamine and cortical muscarinic acetylcholine receptors. J Neurosurg Anesthesiol 1994; 6: 315

11. Durieux ME, Chan CK, Jeter MS: Differential effects of halothane and isoflurane on $\mathrm{ml}$ muscarinic receptors expressed in Xenopus oocytes. Anesth Analg 1995; 80: S109

12. Chan CK, Durieux ME: Halothane inhibits lysophosphatidic acid signaling in Xenopus laevis oocytes. American Cancer Society, 1995 Virginia Annual Meeting Proceedings

13. Chan $\mathrm{CK}$, Durieux ME: Inhibition of angiotensin signaling by isoflurane. Anesthesiology 1995; 83: A661

14. Durieux, ME, Chan CK, Nietgen GW, Washington JM: Inhibition of lysophosphatidate signaling by anesthetics. XVIth Washington International Spring Symposium proceedings. 1996

15. Nietgen GW, Rossi MA, Chan CK, Durieux ME: Propofol suppresses lysophosphatidic acid (LPA)-induced $\mathrm{Ca}^{2+}$ release. Society of Ambulatory Anesthesia 11th Annual Meeting, 1996

16. Nietgen GW, Chan CK, Washington JM, Durieux ME: Lidocaine suppresses lysophosphatidic acid-induced $\mathrm{Ca}^{2+}$ release. $17^{\text {th }}$ International Meeting of the Israel Society of Anesthesiology Abstract Book: 20, 1996.

17. Bavbek M, Nietgen GW, Bogaev C, Fineman MB, Polin R, Chen ZF, Lee KS, Kassell NF, Durieux ME: Increased lysophosphatidate levels in CSF after subarachnoid hemorrhage. Society for Neuroscience 1996; 22:A1566

18. Sitzman BT, Rich GF, Rockwell JJ, Leisure GS, Durieux ME, DiFazio CA: Local anesthetic administration for awake direct laryngoscopy: are glossopharyngeal nerve blocks superior? Anesthesiology 1996; 85:A1203.

19. Chan CK, Durieux ME: Effects of isoflurane on lysophosphatidate signaling: a comparison with halothane. Anesthesiology 1996; 85:A367.

20. Rossi MA, Chan CK, Christensen JD, DeGuzman EJ, Durieux ME: Propofol suppresses lysophosphatidate-induced $\mathrm{Ca}^{2+}$ release in Xenopus oocytes. Anesthesiology 1996; 85:A502.

21. Nietgen GW, Chan CK, Washington JM, Durieux ME: Desflurane has a dose-dependent biphasic effect on $\mathrm{m} 1$ muscarinic signaling. Anesthesiology 1996; 85:A336.

22. Nietgen GW, Chan CK, Durieux ME: Lidocaine and bupivacaine suppress lysophosphatidate-induced $\mathrm{Ca}^{2+}$ release. Anesthesiology 1996; 85:A768.

23. Nietgen GW, Chan CK, Washington JM, Bavbek M, Durieux ME: Dose-dependent suppression of lysophosphatidate signaling by bupivacaine. Postgraduate Assembly in Anesthesiology Proceedings: 114, 1996

24. Nietgen GW, Durieux ME: Ketamine has a nonstereospecific inhibitory effect on rat $\mathrm{m} 1$ muscarinic acetylcholine receptors. Anesth Analg 1997; 84: S528 
25. Chan $\mathrm{CK}$, Durieux ME: Halothane inhibits $\mathrm{G}$ protein-coupled receptor signaling prior to $\mathrm{IP}_{3}$ release in Xenopus laevis oocytes. Anesth Analg 1997; 84: S471

26. Hönemann CW, Baum J, Möllhoff T, Durieux ME: Effects of airway management on recovery following ambulatory procedures: use of low fresh gas flow with laryngeal mask versus endotracheal tube. Society of Ambulatory Anesthesia 12th Annual Meeting, 1997.

27. Hönemann CW, Chan CK, Washington JM, Nietgen GW, Durieux ME: Ethanol enhances intracellular $\mathrm{Ca}^{2+}$ release induced by $\mathrm{ml}$ muscarinic acetylcholine receptor activation. Society of Ambulatory Anesthesia 12th Annual Meeting, 1997.

28. Jonaus LJ, Durieux ME: A comparison of droperidol and ondansetron for nausea prophylaxis in outpatient surgery. Society of Ambulatory Anesthesia 12th Annual Meeting, 1997.

29. Bavbek M, Nietgen GW, Bogaev C, Fineman MB, Polin R, Lee KS, Kassell NF, Durieux ME: Subarachnoid hemorrhage increases CSF lysophosphatidate levels. American Association of Neurological Surgeons Annual Meeting, 1997.

30. Nietgen GW, Chan CK, Hönemann CW, Durieux ME: Ketalar ${ }^{\circledR}$ inhibition of muscarinic signaling is due to synergism between its components. Anesthesiology 1997; 87:A660

31. Nietgen GW, Durieux ME: Desflurane and isoflurane have differential effects on $\mathrm{m} 1 \mathrm{mus-}$ carinic acetylcholine receptor functioning. Anesthesiology 1997; 87:A659

32. Hönemann CW, Chan CK, Nietgen GW, Durieux ME: Influence of sevoflurane and halothane on thromboxane $A_{2}$ receptor signaling. Anesthesiology 1997; 87:A382

33. Hönemann CW, Chan CK, Nietgen GW, Durieux ME: Muscarinic upregulation by ethanol does not involve changes in muscarinic receptor gene expression. Anesthesiology 1997; 87:A337

34. Chan CK, Kamatchi GL, Durieux ME, Lynch C: Isoflurane and halothane inhibit currents through $\alpha_{1 \mathrm{E}} \mathrm{Ca}^{2+}$ channels expressed in Xenopus oocytes. Anesthesiology 1997; 87:A624

35. Hanes C, Campbell S, Hönemann M, Li R, Durieux ME: Supplemental oxygen during transport to PACU: potential cost savings. Anesthesiology 1997; 87: A1010

36. Kamatchi GL, Chan CK, Durieux ME, Lynch C: Anesthetic depression of cardiac (L) and neuronal $(\mathrm{P} / \mathrm{Q})$ voltage-gated currents in calcium channels expressed in Xenopus oocytes. Anesthesiology 1997; 87:A369

37. Kohrs R, Hönemann CW, Nietgen GW, Durieux ME: Lack of etomidate effect on lysophosphatidate signaling: implications for the action of propofol. Anesthesiology 1997; 87:A283

38. Hönemann CW, Arledge JAM, Chan CK, Nietgen GW, Durieux ME: Dose-dependent inhibition of thromboxane $A_{2}$ receptor functioning by lidocaine. Acta Anaesth Scand 1997; 41 (Suppl 111): 135

39. Hönemann CW, Chan CK, Nietgen GW, Durieux ME: Suppression of thromboxane $A_{2}$ $\left(\mathrm{TXA}_{2}\right) \mathrm{G}$ protein-coupled receptor functioning by halothane. Acta Anaesth Scand 1997; 41 (Suppl 111): 334

40. Alden TD, Polin RS, Replogle RE, Bocchicchio BE, Alves W, Warren BB, Durieux ME, Jane JA: Serum magnesium and closed head injury. American Neurosurgical Congress 1998

41. Durieux ME: Cerebral vasospasm: aetiology and pharmacological therapy. Eur J Anaesthesiol 1998; 15 (Suppl 17): 78-79

42. Lo B, Hönemann CW, Errera JS, Polanowska-Grabowska R, Simon CA, Gear AR, Durieux ME: Thromboxane $A_{2}$-induced platelet aggregation is inhibited by lidocaine and bupivacaine. Anesth Analg 1998; 86: SCA81

43. Feirer N, Hönemann CW, Durieux ME: Prolonged bupivacaine exposure inhibits blood coagulation. Anesthesiology 1998; 89: A836 
44. Liu $\mathrm{H}$, Westerling D, Liu W, Durieux ME: Inhibition of recombinant NMDA receptors by $\mathrm{Mg}^{2+}$ and volatile anesthetics. Anesthesiology 1998; 89: A1162

45. Liu H, Liu W, Westerling D, Durieux ME: Volatile anesthetics inhibit signaling of recombinant NMDA receptors. Anesthesiology 1998; 89: A121

46. Fischer LG, Hönemann CW, Hahnenkamp K, Durieux ME, Rich GF: Local anesthetics protect against pulmonary hypertension induced by thromboxane signaling in the isolated rat lung. Anesthesiology 1998; 89: A875

47. Hönemann CW, Podranski T, Lo B, Yanovitch M, Durieux ME: Local anesthetic effects on thromboxane $A_{2}$ signaling. Anesthesiology 1998; 89: A886

48. Hönemann CW, Sertel S, Durieux ME: Effects of volatile anesthetics on prostaglandin $E_{2}$ $\left(\mathrm{PGE}_{2}\right.$ ) receptors (subtype $\mathrm{EP}_{1}$ ) recombinantly expressed in Xenopus oocytes. Anesthesiology 1998; 89: A112

49. Vining VA, Washington JM, Hönemann CW, Lee VC, Durieux ME: Effects of Ca and Mg pretreatment on hyperkalemic cardiac arrest. Anesthesiology 1998; 89: A1195

50. Kamatchi GL, Tiwari SN, Snutch TP, Durieux ME, Lynch C: Volatile anesthetics alter modulation of calcium channels by protein kinase C (PKC). Anesthesiology 1998; 89: A159

51. Kamatchi GL, Chan CK, Snutch TP, Lynch C, Durieux ME: Potentiation of R-type Ca ${ }^{2+}-$ channels by muscarinic receptor activation and its inhibition by halothane and isoflurane. Anesthesiology 1998; 89: A713

52. Lo B, Hönemann CW, Durieux ME: Preemptive analgesia: ketamine and magnesium reduce postoperative morphine requirements after abdominal hysterectomy. Anesthesiology 1998; 89: A1163

\section{Books and book chapters:}

1. Kruyt EW, Durieux ME, Laird JD: Introduction to Measuring in Medicine. Department of Physiology and Physiological Physics, University of Leiden Medical School, 1984.

2. Durieux ME: Lysophosphatidate Signaling: Cellular Effects and Molecular Mechanisms. R.G. Landes Company/Springer Verlag, 1995

3. Durieux ME: Head trauma. In: The Neuroanesthesia Handbook. Stone DJ, Sperry RJ, Johnson JJ, Spiekermann BK, Yemen TA, editors. BC Decker Inc, 1995

4. Durieux ME, Longnecker DE: Failure of the peripheral circulation. In: Complications in Anesthesiology, 2nd ed. Gravenstein N, Kirby RR, editors. Lippincott-Raven, 1995

5. Durieux ME, Schwinn DA: Basic concepts of molecular biology. In: Anesthesia: Biologic Foundations. Yaksh TL, Lynch C II, Zapol WM, Maze M, Biebuyck JF, Saidman LJ, editors. Lippincott-Raven, 1997

6. Durieux, ME: Molecular biology techniques. In: Anesthesia: Biologic Foundations. Yaksh TL, Lynch C III, Zapol WM, Maze M, Biebuyck JF, Saidman LJ, editors. LippincottRaven, 1997

7. Durieux ME: Lysophosphatidate Signaling: Cellular Effects and Molecular Mechanisms. In: Signal Transduction CD-ROM. R.G. Landes Company/Springer Verlag, 1997

8. Durieux ME: Molecular Biology Principles in Anesthesiology. In: Atlas of Clinical Anesthesiology. Miller RD, editor. Current Medicine, 1998

9. Lee A, Durieux ME: The use of Xenopus oocytes for expression and cloning of G proteincoupled receptors. In: Identification and Expression of G Protein-Coupled Receptors. Lynch KR, editor. Wiley-Liss, 1998 
10. Durieux ME: Molecular mechanisms of muscarinic cardiovascular regulation. In: New Advances in Vascular Biology in Molecular Cardiovascular Medicine. Schwinn DA, editor. J.B. Lippincott, 1998

11. Durieux ME, Mounsey JP: Molecular cardiovascular medicine. In: Cardiac Anesthesia, $4^{\text {th }}$ ed. Kaplan J, editor, Lippincott, 1998

12. Hönemann CW, Lo B, Errera JS, Polanowska-Grabowska R, Gear ARI, Durieux ME: Local anesthetic effects on $\mathrm{TXA}_{2}$ receptor-mediated platelet aggregation using quenched-flow aggregometry. (in press)

13. Hönemann CW, Arledge JAM, Podranski T, van Aken $\mathrm{H}$, Durieux ME: Volatile and local anesthetics interfere with thromboxane $A_{2}$ receptors recombinantly expressed in Xenopus oocytes. (in press)

\section{Other publications:}

1. Durieux ME, Lynch KR: Signalling properties of lysophosphatidic acid. Trends Pharmacol Sci 1993; 14: 249-254. [Review]

2. Durieux ME: Muscarinic signaling in the central nervous system: recent developments and anesthetic implications. Anesthesiology 1996; 84: 173-189. [Medical intelligence]

3. Durieux ME: The pharmacologic basis of anesthesiology. Anesthesiology 1996; 84: 1269. [Book review]

4. Warren BB, Durieux ME: Hydroxyethylstarch: safe or not? Anesth Analg 1997; 84: 206212. [Review]

5. Hönemann CW, Brodner G, van Aken H, Ruta U, Durieux ME, Moelhoff T: Aortic rupture during lumbar laminectomy. Anesth Analg 1998; 86: 493-495 [Case report]

6. Nietgen GW, Durieux ME: Intercellular signaling by lysophosphatidate: new developments. J Cell Adhes Comm 1998; 5: 221-235. [Review]

7. Durieux ME: Receptor pharmacology. J Clin Anesthesiol (in press). [Review]

8. Nietgen $\mathrm{GW}$, Hönemann CW, Durieux ME: Influence of anesthetics on endogenous and recombinantly expressed $G$ protein-coupled receptors in the Xenopus oocyte. Toxicol Lett 1998; 100: 319-327 [Review]

9. Hönemann CW, Durieux ME, Theissen JL: Pathophysiologie, Klinik, Diagnostik und Therapie des perioperativen Alkoholdelirs [Pathophysiology, symptomatology, diagnosis and therapy of perioperative alcoholic delirium]. Anästhesist (submitted) [Review]

10. Kohrs R, Durieux ME: Ketamine: teaching an old drug new tricks. Anesth Analg 1998; 87: 1186-1193 [Review] 


\section{Curriculum Vitae}

The author of this thesis was born on November 11, 1959, in Krommenie (The Netherlands). He attended secondary school at the Murmellius Gymnasium in Alkmaar.

After spending one year as an exchange student at Washington \& Lee University, Lexington, VA, he commenced his studies in medicine at the University of Leiden (The Netherlands). He graduated cum laude in 1986.

After a year as Research Associate in the laboratory of David Longnecker at the University of Virginia, he completed his internship at Roanoke Memorial Hospitals, Roanoke, VA, and his residency training in Anesthesiology at the University of Virginia.

From 1991 through 1993 he worked in the laboratory of Kevin Lynch (Pharmacology) at the University of Virginia, as a Research Fellow.

In 1994 he took his position as Assistant Professor in the Department of Anesthesiology at the University of Virginia. In 1998 he was promoted to Associate Professor. He holds secondary appointments as Associate Professor in the Department of Neurological Surgery, and as Assistant Professor in the Department of Pharmacology. 